\title{
DURABILITY AND NEPHELINE CRYSTALLIZATION STUDY FOR HIGH LEVEL WASTE (HLW) SLUDGE BATCH 4 (SB4) GLASSES FORMULATED WITH FRIT 503
}

K.M. Fox

T.B. Edwards

D.K. Peeler

D.R. Best

I.A. Reamer

R.J. Workman

June 2006

Process Science and Engineering Section Savannah River National Laboratory Aiken, SC 29808

Prepared for the U.S. Department of Energy Under Contract Number DEAC09-96SR18500

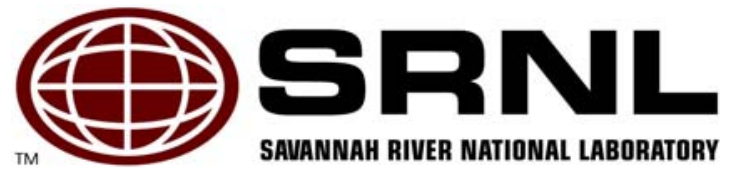




\section{DISCLAIMER}

This report was prepared by Washington Savannah River Company (WSRC) for the United States Department of Energy under Contract No. DE-AC09-96SR18500 and is an account of work performed under that contract. Neither the United States Department of Energy, nor WSRC, nor any of their employees makes any warranty, expressed or implied, or assumes any legal liability or responsibility for the accuracy, completeness, or usefulness, of any information, apparatus, or product or process disclosed herein or represents that its use will not infringe privately owned rights. Reference herein to any specific commercial product, process, or service by trademark, name, manufacturer or otherwise does not necessarily constitute or imply endorsement, recommendation, or favoring of same by WSRC or by the United States Government or any agency thereof. The views and opinions of the authors expressed herein do not necessarily state or reflect those of the United States Government or any agency thereof.

\section{Printed in the United States of America \\ Prepared For \\ U.S. Department of Energy}

The Savannah River National Laboratory is operated for the U.S. Department of Energy by Washington Savannah River Company. 
Keywords: high level waste, glass, durability, crystallization, nepheline

Retention: permanent

\section{DURABILITY AND NEPHELINE CRYSTALLIZATION STUDY FOR HIGH LEVEL WASTE (HLW) SLUDGE BATCH 4 (SB4) GLASSES FORMULATED WITH FRIT 503}

K.M. Fox

T.B. Edwards

D.K. Peeler

D.R. Best

I.A. Reamer

R.J. Workman

June 2006

Process Science and Engineering Section Savannah River National Laboratory Aiken, SC 29808

Prepared for the U.S. Department of Energy Under Contract Number DEAC09-96SR18500

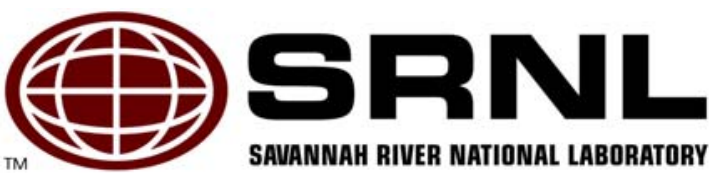




\section{REVIEWS AND APPROVALS}

\section{AUTHORS:}

K.M. Fox, Materials Science and Technology Section

Date

T.B. Edwards, Statistical Consulting Section

Date

D.K. Peeler, Process Science and Engineering Section

Date

D.R. Best, Process Science and Engineering Section

Date

I.A. Reamer, Process Science and Engineering Section

Date

R.J. Workman, Process Science and Engineering Section

Date

TECHNICAL REVIEWER:

C.M. Jantzen, Process Science and Engineering Section

Date

\section{APPROVERS:}

R.E. Edwards, Manager, Process Science and Engineering Section

Date

C.C. Herman, Manager, Process Engineering Technology Group

Date

J.E. Occhipinti, Manager, DWPF Process Engineering

Date 
WSRC-STI-2006-00009

Revision 0

\section{EXECUTIVE SUMMARY}

The Defense Waste Processing Facility (DWPF) is about to process High Level Waste (HLW) Sludge Batch 4 (SB4). This sludge batch is high in alumina and nepheline can crystallize readily depending on the glass composition. Large concentrations of crystallized nepheline can have an adverse effect on HLW glass durability. Several studies have been performed to study the potential for nepheline formation in SB4. The Phase 3 Nepheline Formation study of SB4 glasses examined sixteen different glasses made with four different frits. Melt rate experiments were performed by the Process Science and Engineering Section (PS\&E) of the Savannah River National Laboratory (SRNL) using the four frits from the Phase 3 work, plus additional high $\mathrm{B}_{2} \mathrm{O}_{3}$ /high $\mathrm{Fe}_{2} \mathrm{O}_{3}$ frits. Preliminary results from these tests showed the potential for significant improvements in melt rate for SB4 glasses using a higher $\mathrm{B}_{2} \mathrm{O}_{3}$-containing frit, particularly Frit 503. The main objective of this study was to investigate the durability of SB4 glasses produced with a high $\mathrm{B}_{2} \mathrm{O}_{3}$ frit likely to be recommended for SB4 processing. In addition, a range of waste loadings (WLs) was selected to continue to assess the effectiveness of a nepheline discriminator in predicting concentrations of nepheline crystallization that would be sufficient to influence the durability response of the glass. Five glasses were selected for this study, covering a WL range of 30 to $50 \mathrm{wt} \%$ in $5 \mathrm{wt} \%$ increments.

The Frit 503 glasses were batched and melted. Specimens of each glass were heat-treated to simulate cooling along the centerline of a DWPF-type canister (ccc) to gauge the effects of thermal history on product performance. Visual observations on both quenched and ccc glasses were documented. A representative sample from each glass was submitted to the SRNL Process Science Analytical Laboratory (PSAL) for chemical analysis to confirm that the as-fabricated glasses corresponded to the defined target compositions. The Product Consistency Test (PCT, ASTM C1285) was performed in triplicate on each Frit 503 quenched and ccc glass to assess chemical durability. The experimental test matrix also included the Environmental Assessment (EA) glass and the Approved Reference Material (ARM-1) glass. Representative samples of all the ccc glasses were examined for homogeneity visually and by X-ray diffraction (XRD) analysis.

Chemical composition measurements indicated that the experimental glasses were close to their target compositions. PCT results showed that all of the Fit 503 quenched glasses had an acceptable durability compared to the EA benchmark glass. The durability of one of the ccc glasses, NEPHB-04, was statistically greater than its quenched counterpart. However, this was shown to be of little practical significance, as the durability of the NEPHB-04 ccc glass was acceptable when compared to the durability of the EA benchmark glass.

Visual observations and PCT results indicated that all of the Frit 503 quenched glasses were free of any crystallization that impacts durability. For the ccc glasses, XRD results indicated that the lower WL glasses (30 to $40 \mathrm{wt} \%$ ) were amorphous, which was consistent with visual observations and PCT responses. The higher WL glasses (45 and $50 \mathrm{wt} \%$ ) were shown by XRD to contain spinel (trevorite, $\mathrm{NiFe}_{2} \mathrm{O}_{4}$ ). It is possible that some of the other high WL glasses also contained some nepheline, but that the amount of nepheline crystallization was below the detection limit $(0.5 \mathrm{vol} \%)$ associated with XRD.

The results indicate that Frit 503 is a good candidate for SB4 processing, based on chemical durability of homogeneous and devitrified glasses over a WL range of $30-50 \%$. It should be noted that the higher WL glasses would not be fit for processing in DWPF as they exceed other process related criteria (such as liquidus temperature). However, this is only one of many factors influencing the frit selection. Melt rate and the final SB4 composition are also important factors in frit selection. Additional melt rate studies are currently underway, and the final composition projection for SB4 is expected shortly. 


\section{TABLE OF CONTENTS}

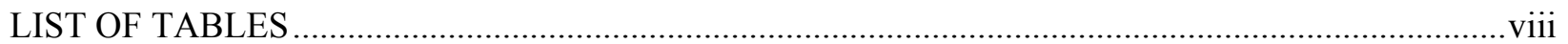

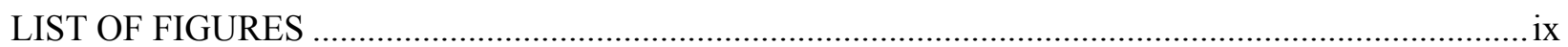

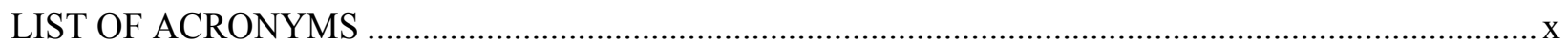

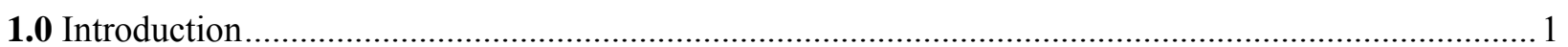

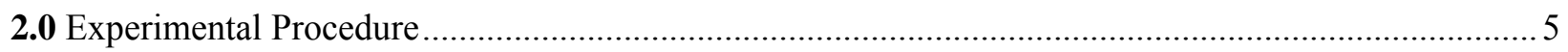

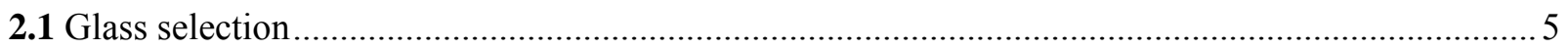

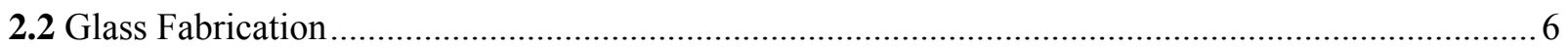

2.3 Measurement of the Properties and Performance of the Glasses ................................................... 7

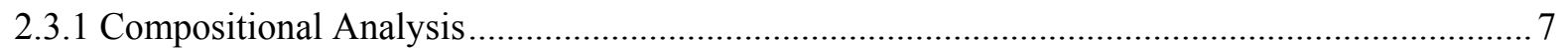

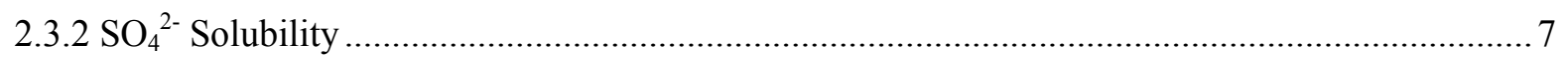

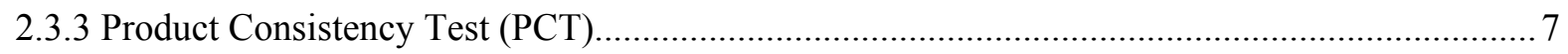

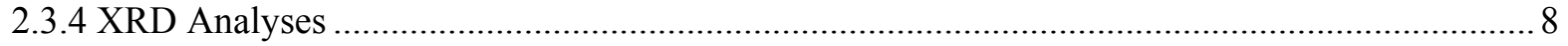

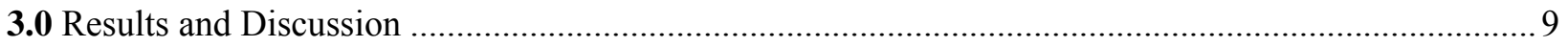

3.1 A Statistical Review of the Chemical Composition Measurements for the Frit 503 Glasses ............ 9

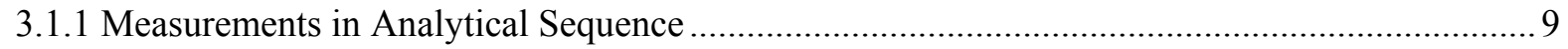

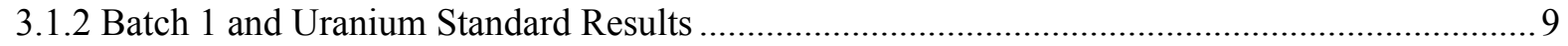

3.1.3 Composition Measurements by Glass Number ..................................................................... 10

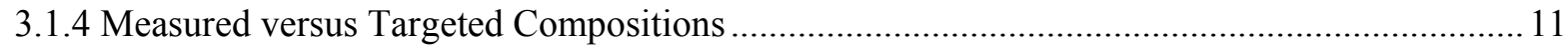

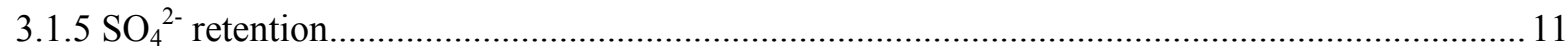

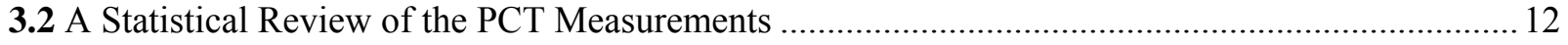

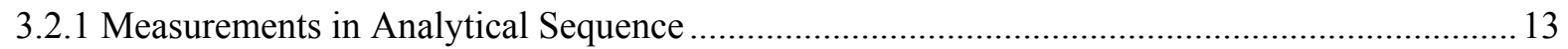

3.2.2 Results for the Samples of the Multi-Element Solution Standard ............................................ 13

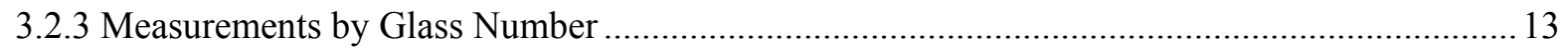

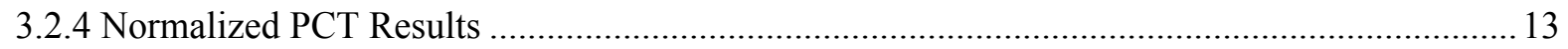

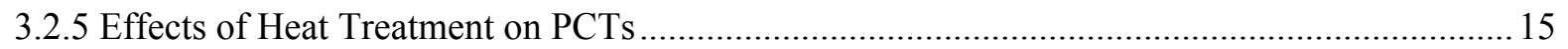

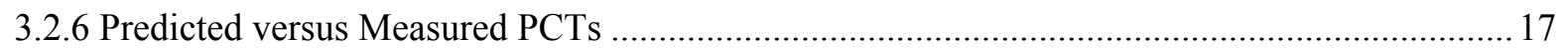

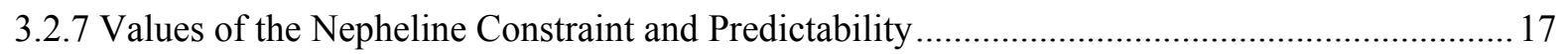

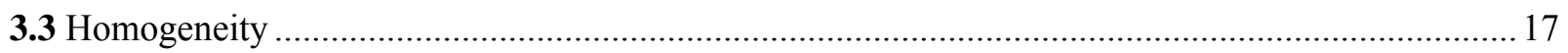

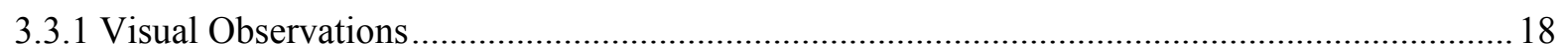

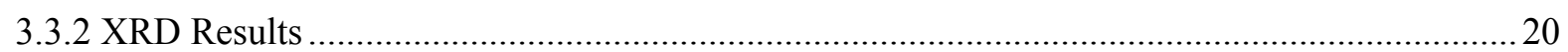

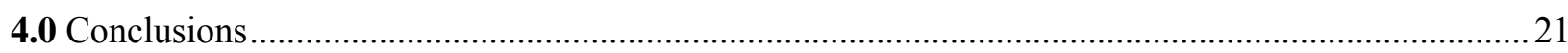

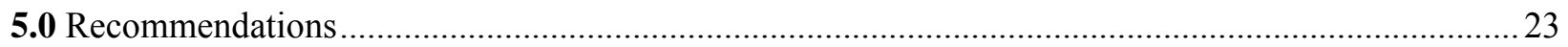




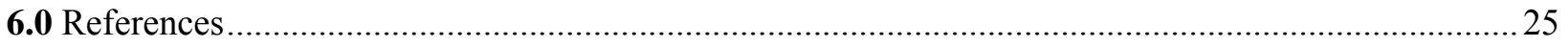

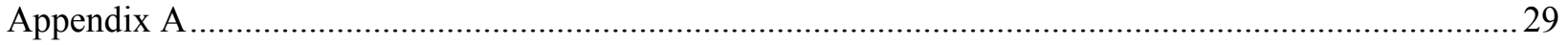

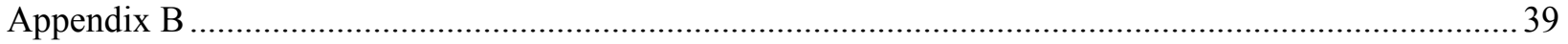

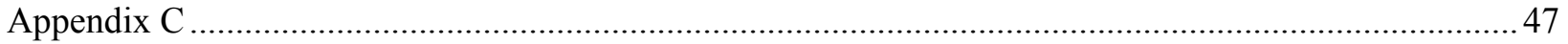

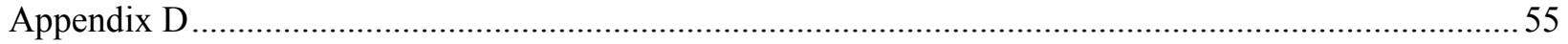

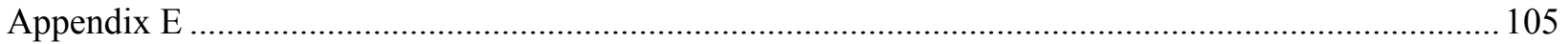




\section{LIST OF TABLES}

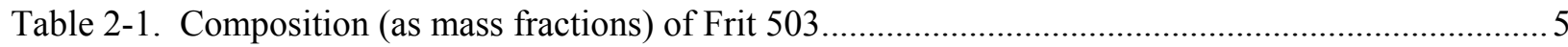

Table 2-2. Target Compositions of the Frit 503 Glasses (in wt \%). ...................................................... 6

Table 3-1. Results from Samples of the Multi-Element Solution Standard........................................... 13

Table 3-2. Normalized PCTs by Glass ID/Compositional View ........................................................ 15

Table 3-3. Nepheline Constraint Values by Composition View ............................................................ 17

Table 3-4. Visual observations and XRD results for the Frit 503 glasses. ........................................... 19 


\section{LIST OF FIGURES}

Figure 3-1. Average Measured and Bias-Corrected versus Targeted $\mathrm{SO}_{4}{ }^{2-}$ Values ................................ 12

Figure 3-2. Normalized releases for boron, based on the measured compositions, for

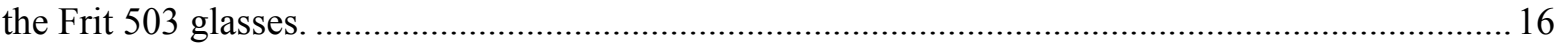




\section{LIST OF ACRONYMS}

$\begin{array}{ll}\text { AD } & \text { Analytical Development } \\ \text { ANOVA } & \text { ANalysis Of VAriance } \\ \text { ARM } & \text { Approved Reference Material } \\ \text { ARP } & \text { Actinide Removal Process } \\ \text { ASTM } & \text { American Society for Testing and Materials } \\ \text { bc } & \text { bias-corrected } \\ \text { CBU } & \text { Closure Business Unit } \\ \text { ccc } & \text { centerline canister cooled } \\ \text { DWPF } & \text { Defense Waste Processing Facility } \\ \text { EA } & \text { Environmental Assessment } \\ \text { HLW } & \text { High Level Waste } \\ \text { ICP-AES } & \text { Inductively Coupled Plasma - Atomic Emission Spectroscopy } \\ \text { LM } & \text { Lithium-Metaborate } \\ \text { LWO } & \text { Liquid Waste Operations } \\ \text { MAR } & \text { Measurement Acceptability Region } \\ \text { PCCS } & \text { Product Composition Control System } \\ \text { PCT } & \text { Product Consistency Test } \\ \text { PF } & \text { Peroxide Fusion } \\ \text { PSAL } & \text { Process Science Analytical Laboratory } \\ \text { SB4 / SB5 } & \text { Sludge Batch 4 / Sludge Batch 5 } \\ \text { SME } & \text { Slurry Mix Evaporator } \\ \text { SRL } & \text { Savannah River Laboratory } \\ \text { SRNL } & \text { Savannah River National Laboratory } \\ T_{L} & \text { liquidus temperature } \\ \text { WL } & \text { Waste Loading (weight percent) } \\ \text { XRD } & \end{array}$




\subsection{Introduction}

Crystallization (or devitrification) is an important factor in the processing and performance of nuclear waste glass. In terms of processing, the Defense Waste Processing Facility (DWPF) uses a liquidus temperature $\left(\mathrm{T}_{\mathrm{L}}\right)$ mode ${ }^{1-3}$ and an imposed $\mathrm{T}_{\mathrm{L}}$ limit for feed acceptability to avoid bulk devitrification within the melter. In terms of performance of the glass waste form, the impact of devitrification on durability depends on the type and extent of crystallization.

Numerous studies ${ }^{4-11}$ have assessed the potential for devitrification in various high level waste (HLW) glasses and its impact on durability. These studies generally agree that the impact of devitrification on durability is dependent upon the type and extent of crystallization. For example, a strong increase in the rate of glass dissolution (or decrease in durability) was observed in studies ${ }^{6,11-13}$ of glasses that formed aluminum-containing crystals, such as $\mathrm{NaAlSiO}_{4}$ (nepheline), $\mathrm{LiAlSi}_{2} \mathrm{O}_{6}$, or crystalline $\mathrm{SiO}_{2}$. The report by Jantzen and Bickford ${ }^{11}$ also indicated that the formation of spinel had little or no effect on the durability of Savannah River Laboratory (SRL) 165- or SRL 131-based glasses, while the formation of acmite produced a small but noticeable increase in the rate of dissolution of the matrix glass. The impact of devitrification on durability is complex and depends on several interrelated factors including the change in residual glass composition, the development of internal stress or microcracks, and preferential attack at the glass - crystal interface.

The next sludge batch to be processed by DWPF, Sludge Batch 4 (SB4), is projected to contain a relatively large concentration of $\mathrm{Al}_{2} \mathrm{O}_{3} .{ }^{14}$ While the addition of $\mathrm{Al}_{2} \mathrm{O}_{3}$ to borosilicate glasses generally enhances the durability of the waste form (through creation of network-forming tetrahedral $\mathrm{Na}^{+}-\left[\mathrm{AlO}_{4 / 2}\right]^{-}$ pairs), nepheline formation, which depends in part on the $\mathrm{Al}_{2} \mathrm{O}_{3}$ content, can result in severe deterioration of the chemical durability of the glass through residual glass compositional changes and microcracking. Three moles of glass forming oxides $\left(\mathrm{Al}_{2} \mathrm{O}_{3}\right.$ and $\left.2 \mathrm{SiO}_{2}\right)$ are removed from the continuous glass phase per each mole of $\mathrm{Na}_{2} \mathrm{O}$ as nepheline crystallizes. Therefore, nepheline formation produces an $\mathrm{Al}_{2} \mathrm{O}_{3}$ and $\mathrm{SiO}_{2}$ deficient continuous glass matrix (relative to the same composition without crystallization) which reduces the durability of the final product. The magnitude of the reduction ultimately depends on the extent (volume fraction) of crystallization.

Li et al. ${ }^{9} 15$ indicated that sodium alumino-borosilicate glasses are prone to nepheline crystallization if their compositions projected on the $\mathrm{Na}_{2} \mathrm{O}-\mathrm{Al}_{2} \mathrm{O}_{3}-\mathrm{SiO}_{2}$ ternary fall within or close to the nepheline primary phase field. In particular, glasses with $\mathrm{SiO}_{2} /\left(\mathrm{SiO}_{2}+\mathrm{Na}_{2} \mathrm{O}+\mathrm{Al}_{2} \mathrm{O}_{3}\right)>0.62$, where the chemical formulae stand for the mass fractions in the glass, do not tend to precipitate nepheline as a primary crystalline phase.

Initial composition projections of $\mathrm{SB} 4{ }^{14}$ indicated that the sludge will be enriched in $\mathrm{Al}_{2} \mathrm{O}_{3}$ relative to the $\mathrm{Al}_{2} \mathrm{O}_{3}$ concentrations of previous sludge batches processed through the DWPF. Candidate frits were identified which ranged in $\mathrm{Na}_{2} \mathrm{O}$ concentration from $8-13 \%$ by mass for the initial SB4 composition projections. ${ }^{16}$ The combination of high $\mathrm{Al}_{2} \mathrm{O}_{3}$ and $\mathrm{Na}_{2} \mathrm{O}$ concentrations, coupled with lower $\mathrm{SiO}_{2}$ concentrations as waste loadings are increased (given the primary source of $\mathrm{SiO}_{2}$ is from the frit), shifts the overall glass compositions toward the nepheline phase field, raising the potential for nepheline crystallization. Therefore, strategic frit development efforts ${ }^{17}$ have been made to suppress the development of nepheline formation by lowering the $\mathrm{Na}_{2} \mathrm{O}$ content while increasing $\mathrm{B}_{2} \mathrm{O}_{3}, \mathrm{Fe}_{2} \mathrm{O}_{3}$, and/or $\mathrm{Li}_{2} \mathrm{O}$ concentration in the frit.

Peeler et al. ${ }^{18,19}$ provided insight into the potential impact of nepheline formation on SB4 glasses based on the Lilliston ${ }^{14}$ SB4 composition projections. In that study (referred to as Phase 1), twelve SB4-based glasses were fabricated (only two of which were prone to nepheline formation using the 0.62 value of $\mathrm{Li}$ et $a .^{15}$ as a guide) and the durability of each was measured. The results indicated that all the glasses in 
the Phase 1 study (both quenched and centerline canister cooled (ccc)) had a durability as defined by the Product Consistency Test (PCT) ${ }^{20}$ that was acceptable (lower than the EA benchmark glass). The two glasses prone to nepheline formation (NEPH-01 and NEPH-02) had a statistically significant difference in PCT response between the quenched and ccc versions, but the durability of the ccc glasses, while decreased, was still considerably better than that of the EA glass. ${ }^{21}$ When the PCT responses were coupled with the X-ray diffraction (XRD) results and/or visual observations, it was concluded that the formation of nepheline in these glasses did have a negative impact on durability, though in this case the impact was not of practical concern. The results of the Phase 1 study suggested that the 0.62 value, as proposed by Li et al., ${ }^{15}$ appeared to be a reasonable guide to monitor the potential for nepheline formation in the alumino-borosilicate based SB4 glass system.

After issuance of the Phase 1 report, revised composition projections from the Closure Business Unit (CBU) for SB4 were issued. ${ }^{22,23}$ In response to these revised projections, candidate frits whose operating windows (i.e., waste loading intervals that meet Product Composition Control System (PCCS) Measurement Acceptability Region (MAR) criteria) are robust to and/or selectively optimal for these sludge options were identified via a paper study. ${ }^{24}$ The results of the paper study indicated that candidate frits were available for the various SB4 options presented and relatively large operating windows were provided. In addition, the 0.62 value for the nepheline discriminator was used as a screening tool to evaluate the potential impact of nepheline formation on the projected operating windows. The results of applying the nepheline discriminator ${ }^{24}$ indicated that access to higher WLs for almost all SB4 frit - sludge options was restricted. That is, a relatively large WL interval was available in which all PCCS MAR criteria were satisfied except when the nepheline discriminator value was invoked. This suggested possible composition regions associated with crystallization and its potentially adverse impact on durability. Therefore, the value of the nepheline discriminator was challenged to determine if access to those higher WLs could be regained without compromising durability.

Phase 2 of the nepheline crystallization study ${ }^{25}$ was then undertaken to complement the Phase 1 work ${ }^{19}$ by selecting glasses to cover WLs over which nepheline was the only criterion restricting acceptability. The primary difference between the Phase 1 and Phase 2 nepheline studies was that Phase 2 challenged the nepheline discriminator for all glasses tested - not just a few select glasses as in Phase 1. In order to meet this objective, WLs of $\sim 40 \%$ or higher were targeted for the Phase 2 glasses, ${ }^{26}$ whereas $40 \%$ was the maximum WL used during Phase 1. Twenty eight glasses, encompassing five different frit compositions (Frit 320, Frit 417, Frit 425, Frit 426, and Frit 418), were fabricated and tested following the experimental methods used in Phase 1.

All of the Phase 2 quenched glasses had normalized boron releases of less than $1.19 \mathrm{~g} / \mathrm{L}$, which is approximately an order of magnitude better than the EA benchmark glass. ${ }^{21}$ However, the potential for crystallization is suppressed kinetically in quenched glasses. That is, the glasses may have been prone to nepheline formation but the rapid cooling limited the formation of nepheline (or other crystalline phases). For the Phase $2 \mathrm{ccc}$ glasses, visual observations suggested that as the targeted WL within a specific frit sludge system was increased, the degree of crystallization became more extensive. This is expected, as the slower cooling rate provides the kinetic path for a glass with a composition that is thermodynamically favorable for nepheline formation (i.e., a composition that falls within the nepheline primary phase field) to devitrify. XRD results indicated the presence of nepheline, trevorite $\left(\mathrm{NiFe}_{2} \mathrm{O}_{4}\right)$, and/or lithium silicate $\left(\mathrm{Li}_{2} \mathrm{SiO}_{3}\right)$ in select Phase $2 \mathrm{ccc}$ glasses. Also, the difference between the quenched and ccc PCT response for each specific frit system increased as WL increased. Coupling this trend with the XRD crystallization results, the durability responses as a function of WL were easily explained. As WL increased within a specific frit - sludge system, the durability of the ccc based glasses decreased due to the formation of nepheline and/or lithium silicate. These trends are in agreement with previous observations that the impact on durability is dependent upon the type and extent of crystallization and the resulting change in the residual glass composition. 
For Phase 3 of the nepheline study, 16 glasses were selected ${ }^{27}$ to complement the earlier work ${ }^{19,25}$ by continuing the investigation into the ability of the nepheline discriminator to predict the occurrence of nepheline crystallization in SB4 glasses and into the impact of such phases on the durability of the SB4 glasses. Four frits (Frit 418, Frit 425, Frit 501, and Frit 502) were used, combined with the most recent composition projection for SB4. ${ }^{28}$ A primary objective of the Phase 3 study was to continue to demonstrate the ability of the nepheline discriminator value to adequately predict the nepheline formation potential for specific glass systems of interest. Glasses were selected to cover WLs that tightly bound the nepheline discriminator value of 0.62 , with the intent of refining this value to a level of confidence where it could be incorporated into offline administrative controls and/or the PCCS to support Slurry Mix Evaporator (SME) acceptability decisions. In addition, lower WLs $(30-40 \%)$ were targeted which provided consistency with the Phase 2 work.

The results of the Phase 3 study $^{29}$ concurred with the earlier phases in that a nepheline discriminator of 0.62 was shown to be the appropriate value for screening out glasses with the potential for nepheline crystallization upon slow cooling (and therefore reduced chemical durability). The results also showed that the nepheline discriminator was successful in screening out the one glass in the study that contained nepheline and would be unpredictable by the $\Delta \mathrm{G}_{\mathrm{P}}$ model. ${ }^{30}$

Following the Phase 3 study, melt rate experiments were performed using the four frits from the Phase 3 work, and additional high $\mathrm{B}_{2} \mathrm{O}_{3} /$ high $\mathrm{Fe}_{2} \mathrm{O}_{3}$ frits. Preliminary results from these tests showed the potential for significant improvements in melt rate for SB4 glasses using a higher $\mathrm{B}_{2} \mathrm{O}_{3}$-containing frit, particularly Frit 503. ${ }^{31}$ As Frit 503 / SB4 glasses had not yet been examined experimentally for durability performance, a small study was undertaken, which is the focus of this report. The main objective of this study was to investigate the durability of SB4 glasses produced with a high $\mathrm{B}_{2} \mathrm{O}_{3}$ frit likely to be recommended (based on the information in hand) for SB4 processing. In addition, a range of WLs were selected to continue to assess the effectiveness of a nepheline discriminator value of 0.62 in predicting nepheline crystallization sufficient to influence the durability response of the glass.

The results of this study will provide valuable input for the frit development efforts and subsequent feedback to Liquid Waste Operations (LWO) regarding the viability of a high $\mathrm{B}_{2} \mathrm{O}_{3}$ frit option (Frit 503) for SB4 vitrification. Additional data provided through other studies, such as the continuing melt rate experiments, will also influence the frit recommendation decision for SB4. This work was initiated by a Technical Task Request ${ }^{32}$ and is covered by a Technical Task and Quality Assurance Plan. ${ }^{33}$ 
WSRC-STI-2006-00009

Revision 0

This page intentionally left blank. 
WSRC-STI-2006-00009

Revision 0

\subsection{Experimental Procedure}

\subsection{Glass selection}

Five glass compositions were selected for this study. Only one sludge option, Case 15C Blend 1 ( $\sim 96$ inch SB3 heel, SB4 washed to $1.4 \mathrm{M} \mathrm{Na}^{+}$before blending $)^{28}$ was used as this option was seen as providing the most likely representation of SB4 at the time this task was initiated. A high $\mathrm{B}_{2} \mathrm{O}_{3}$ frit (Frit 503) was chosen for this study based on preliminary melt rate experiments ${ }^{\mathrm{a}}$ and the assessments associated with projected operating windows. ${ }^{34}$ The melt rate experiments showed a significant improvement in melt rate for Frit 503 / SB4 glasses compared with earlier, lower $\mathrm{B}_{2} \mathrm{O}_{3}$ frits. Frit 503, whose composition is given in Table 2-1, was used in the current study. The model-based MAR assessment indicated that the high $\mathrm{B}_{2} \mathrm{O}_{3}$-based frits suppressed nepheline formation to higher WLs which ultimately resulted in an another property (besides nepheline crystallization) defining the maximum WL attainable via PCCS. ${ }^{34}$

Table 2-1. Composition (as mass fractions) of Frit 503.

\begin{tabular}{|c|c|c|c||}
\hline $\mathbf{B}_{2} \mathbf{O}_{3}$ & $\mathbf{L i}_{2} \mathbf{O}$ & $\mathbf{N a}_{2} \mathbf{O}$ & $\mathbf{S i O}_{2}$ \\
\hline 0.14 & 0.08 & 0.04 & 0.74 \\
\hline
\end{tabular}

The frit and sludge were combined at five WL levels to examine the durability and potential for nepheline crystallization of Frit 503 / SB4 glasses over a range of WLs. The WLs utilized covered a range likely to be processed at DWPF (i.e., $30-40 \% \mathrm{WL}$ ), as well as higher WLs to challenge nepheline formation (i.e., 45 and $50 \% \mathrm{WL}$ ). It should be noted that at these higher WLs, other properties (in particular $\mathrm{T}_{\mathrm{L}}$ ) may not have been acceptable, but in order to meet study objectives (challenge nepheline formation and/or refine the discriminator value), other processing criteria were ignored. More specifically, given the higher $\mathrm{B}_{2} \mathrm{O}_{3}$ and lower $\mathrm{Na}_{2} \mathrm{O}$ concentrations of Frit $503, \mathrm{~T}_{\mathrm{L}}$ predictions limit WLs with Case $15 \mathrm{C}$ Blend 1 to $43 \%$ or lower. At $44 \% \mathrm{WL}, \mathrm{T}_{\mathrm{L}}$ predictions exceed the control limits in PCCS. Therefore, DWPF would be restricted from processing the 45 and 50\% WL glasses - although these WLs will be targeted in this study.

The target compositions of the five Frit 503 / SB4 glasses (NEPHB-01 through NEPHB-05) are listed in Table 2-2. Values of the nepheline discriminator, calculated using the target compositions, are also given.

\footnotetext{
a See WSRC-NB-2006-00017, page 40, for details and results of the melt rate experiments.
} 
Table 2-2. Target Compositions of the Frit 503 Glasses (in wt\%).

\begin{tabular}{|c|c|c|c|c|c|}
\hline Glass ID & NEPHB-01 & NEPHB-02 & NEPHB-03 & NEPHB-04 & NEPHB-05 \\
\hline$\% \mathrm{WL}$ & 30 & 35 & 40 & 45 & 50 \\
\hline $\begin{array}{c}\text { nepheline } \\
\text { discriminator }\end{array}$ & 0.759 & 0.723 & 0.685 & 0.646 & 0.606 \\
\hline $\mathrm{Al}_{2} \mathrm{O}_{3}$ & 7.4417 & 8.6820 & 9.9223 & 11.1626 & 12.4029 \\
\hline $\mathrm{B}_{2} \mathrm{O}_{3}$ & 9.8000 & 9.1000 & 8.4000 & 7.7000 & 7.0000 \\
\hline $\mathrm{BaO}$ & 0.0378 & 0.0441 & 0.0504 & 0.0567 & 0.0630 \\
\hline $\mathrm{CaO}$ & 0.7162 & 0.8356 & 0.9550 & 1.0743 & 1.1937 \\
\hline $\mathrm{Ce}_{2} \mathrm{O}_{3}$ & 0.0449 & 0.0524 & 0.0599 & 0.0674 & 0.0749 \\
\hline $\mathrm{Cr}_{2} \mathrm{O}_{3}$ & 0.0636 & 0.0742 & 0.0848 & 0.0954 & 0.1061 \\
\hline $\mathrm{CuO}$ & 0.0179 & 0.0209 & 0.0239 & 0.0269 & 0.0299 \\
\hline $\mathrm{Fe}_{2} \mathrm{O}_{3}$ & 7.9697 & 9.2979 & 10.6262 & 11.9545 & 13.2827 \\
\hline $\mathrm{K}_{2} \mathrm{O}$ & 0.1032 & 0.1204 & 0.1376 & 0.1548 & 0.1721 \\
\hline $\mathrm{La}_{2} \mathrm{O}_{3}$ & 0.0325 & 0.0379 & 0.0434 & 0.0488 & 0.0542 \\
\hline $\mathrm{Li}_{2} \mathrm{O}$ & 5.6000 & 5.2000 & 4.8000 & 4.4000 & 4.0000 \\
\hline $\mathrm{MgO}$ & 0.7486 & 0.8734 & 0.9982 & 1.1229 & 1.2477 \\
\hline $\mathrm{MnO}$ & 1.6440 & 1.9180 & 2.1920 & 2.4660 & 2.7401 \\
\hline $\mathrm{Na}_{2} \mathrm{O}$ & 9.4239 & 10.3279 & 11.2318 & 12.1358 & 13.0398 \\
\hline $\mathrm{NiO}$ & 0.4731 & 0.5520 & 0.6308 & 0.7097 & 0.7886 \\
\hline $\mathrm{PbO}$ & 0.0271 & 0.0317 & 0.0362 & 0.0407 & 0.0452 \\
\hline $\mathrm{SO}_{4}{ }^{2-}$ & 0.4014 & 0.4683 & 0.5352 & 0.6021 & 0.6690 \\
\hline $\mathrm{SiO}_{2}$ & 53.0340 & 49.5396 & 46.0453 & 42.5509 & 39.0566 \\
\hline $\mathrm{ThO}_{2}$ & 0.0197 & 0.0230 & 0.0263 & 0.0296 & 0.0329 \\
\hline $\mathrm{TiO}_{2}$ & 0.0080 & 0.0093 & 0.0107 & 0.0120 & 0.0133 \\
\hline $\mathrm{U}_{3} \mathrm{O}_{8}$ & 2.2921 & 2.6741 & 3.0561 & 3.4381 & 3.8201 \\
\hline $\mathrm{ZnO}$ & 0.0293 & 0.0342 & 0.0390 & 0.0439 & 0.0488 \\
\hline $\mathrm{ZrO}_{2}$ & 0.0711 & 0.0830 & 0.0948 & 0.1067 & 0.1185 \\
\hline Sum & 100.0000 & 100.0000 & 100.0000 & 100.0000 & 100.0000 \\
\hline
\end{tabular}

\subsection{Glass Fabrication}

Each Frit 503 glass was prepared from the proper proportions of reagent-grade metal oxides, carbonates, boric acid, and salts in $150 \mathrm{~g}$ batches. ${ }^{35}$ The raw materials were thoroughly mixed and placed into a $95 \%$ Platinum $/ 5 \%$ Gold $250 \mathrm{~mL}$ crucible. The batch was placed into a high-temperature furnace at the target melt temperature of $1150^{\circ} \mathrm{C}^{36}$ After an isothermal hold at $1150^{\circ} \mathrm{C}$ for $1.0 \mathrm{~h}$, the crucible was removed from the furnace. The glass was poured onto a clean stainless steel plate and allowed to air cool (quench). The glass pour patty was used as a sampling stock for the various property measurements (i.e., chemical composition and durability).

Approximately $25 \mathrm{~g}$ of each glass was heat-treated to simulate cooling along the centerline of a DWPFtype canister ${ }^{8}$ to gauge the effects of thermal history on product performance. This cooling schedule is referred to as the ccc curve. Visual observations on both quenched and ccc glasses were documented. ${ }^{\mathrm{a}}$

\footnotetext{
a WSRC-NB-2006-00016 contains the visual observations of the quenched and ccc glasses as well as the results of the XRD and PCT analyses for the Frit 503 glasses.
} 
WSRC-STI-2006-00009

Revision 0

\subsection{Measurement of the Properties and Performance of the Glasses}

This section provides a general discussion of the chemical composition analyses, the PCTs, and the XRD analyses of the Frit 503 glasses.

\subsubsection{Compositional Analysis}

To confirm that the as-fabricated glasses corresponded to the defined target compositions, a representative sample from each glass was submitted to the SRNL Process Science Analytical Laboratory (PSAL) for chemical analysis under the auspices of an analytical plan. The plan (see Appendix A) identified the cations to be analyzed and the dissolution techniques (i.e., sodium peroxide fusion [PF] and lithiummetaborate $[\mathrm{LM}])$ to be used. The samples prepared by LM were used to measure barium $(\mathrm{Ba})$, calcium $(\mathrm{Ca})$, cerium $(\mathrm{Ce})$, chromium $(\mathrm{Cr})$, copper $(\mathrm{Cu})$, potassium $(\mathrm{K})$, lanthanum $(\mathrm{La})$, magnesium $(\mathrm{Mg})$, manganese $(\mathrm{Mn})$, sodium $(\mathrm{Na})$, lead $(\mathrm{Pb})$, sulfur $(\mathrm{S})$, thorium $(\mathrm{Th})$, titanium $(\mathrm{Ti})$, zinc $(\mathrm{Zn})$, and zirconium ( $\mathrm{Zr}$ ) concentrations. Samples prepared by PF were used to measure aluminum (Al), boron (B), iron (Fe), lithium ( $\mathrm{Li})$, nickel $(\mathrm{Ni})$, silicon $(\mathrm{Si})$, and uranium $(\mathrm{U})$ concentrations. Each glass was prepared in duplicate for each cation dissolution technique (PF and LM). All of the prepared samples were analyzed (twice for each element of interest) by Inductively Coupled Plasma - Atomic Emission Spectroscopy (ICP-AES) with the instrumentation being re-calibrated between the duplicate analyses. The analytical plan was developed in such a way as to provide the opportunity to evaluate potential sources of error. Glass standards were also intermittently measured to assess the performance of the ICP-AES instrument over the course of these analyses.

\subsection{2 $\mathrm{SO}_{4}{ }^{2-}$ Solubility}

Although not a primary focus of this study, $\mathrm{SO}_{4}{ }^{2-}$ solubility is of concern for SB4 glass systems. The applicability of the current $0.6 \mathrm{wt} \% \mathrm{SO}_{4}{ }^{2-}$ limit (established for the Frit $418-\mathrm{SB} 3$ system $^{37}$ ) to SB4 was investigated. From Table 2-2, the targeted $\mathrm{SO}_{4}{ }^{2-}$ concentrations in the Frit 503 glasses range from 0.401 to $0.669 \mathrm{wt} \%$. Previous tests have suggested that the use of reagent grade raw materials is conservative with respect to $\mathrm{SO}_{4}{ }^{2-}$ retention and/or volatility. ${ }^{\text {a }}$ Since the Frit 503 glasses have both high $\mathrm{SO}_{4}{ }^{2-}$ concentrations and are batched from reagent grade raw materials, the ability of the glasses to retain the targeted $\mathrm{SO}_{4}{ }^{2-}$ concentrations will provide valuable insight into the applicability of the current $\mathrm{SO}_{4}{ }^{2-}$ limit to SB4. Both visual observations (i.e., formation of a salt layer on the surface of the glass indicating that $\mathrm{SO}_{4}{ }^{2-}$ limit has been exceeded) and a comparison of measured versus targeted $\mathrm{SO}_{4}{ }^{2-}$ concentrations were used to support this assessment.

\subsubsection{Product Consistency Test (PCT)}

The $\mathrm{PCT}^{20}$ was performed in triplicate on each Frit 503 quenched and ccc glass to assess chemical durability. Also included in the experimental test matrix was the EA glass, ${ }^{21}$ the Approved Reference Material (ARM-1) glass, and blanks from the sample cleaning batch. Samples were ground, washed, and prepared according to the standard procedure. ${ }^{20}$ Approximately fifteen milliliters of Type I American Society for Testing and Materials (ASTM) water were added to approximately $1.5 \mathrm{~g}$ of glass in stainless steel vessels. The vessels were closed, sealed, and placed in an oven at $90 \pm 2{ }^{\circ} \mathrm{C}$ where the samples were maintained for 7 days. Once cooled, the resulting solutions were sampled (filtered and acidified), then labeled and analyzed by PSAL under the auspices of an analytical plan (see Appendix B). The aim of the plan was to provide an opportunity to assess the consistency (repeatability) of the PCT and analytical procedures to evaluate the chemical durability of the Frit 503 glasses. Normalized release rates were calculated based on targeted, measured, and bias-corrected (bc) compositions using the average of the logs of the leachate concentrations.

\footnotetext{
a Previous results have indicated that the use of raw materials (reagent grade chemicals) to produce the glasses minimizes $\mathrm{SO}_{4}{ }^{2-}$ volatilization during the fabrication process. Since volatilization is anticipated in slurry-fed melters, this approach will provide a conservative measure of $\mathrm{SO}_{4}{ }^{2-}$ retention in the glass.
} 
As will be discussed in Section 3.0, the PCT results indicated a possible sample labeling error for two of the ccc glasses, NEPHB-04 and NEPHB-05. The PCT was run a second time for all of the ccc glasses to determine whether an error had indeed been made. A second analytical plan was written for these experiments and is included as Appendix C.

\subsubsection{XRD Analyses}

Although visual observations for crystallization were performed and documented, representative samples for all ccc Frit 503 glasses were submitted to Analytical Development (AD) for XRD analyses. The quenched glasses were not submitted for XRD analyses based on visual observations and the PCT responses. Samples were run under conditions providing a detection limit of approximately $0.5 \mathrm{vol} \%$. That is, if crystals (or undissolved solids) were present at $0.5 \mathrm{vol} \%$ or greater, the diffractometer would not only be capable of detecting the crystals but would also allow a qualitative determination of the type of crystal(s) present. Otherwise, a characteristically high background devoid of crystalline peaks indicated that the glass product was amorphous, suggesting either a completely amorphous product or that the degree of crystallization was below the detection limit. 
WSRC-STI-2006-00009

Revision 0

\subsection{Results and Discussion}

\subsection{A Statistical Review of the Chemical Composition Measurements for the Frit $\mathbf{5 0 3}$ Glasses}

In this section, the measured versus targeted compositions of the five SB4/Frit 503 study glasses (NEPHB-01 through NEPHB-05) are presented and compared. The targeted compositions for these glasses are provided in Table 2-2, as well as Table D1 of Appendix D. A sum of oxides column is provided in these tables as well. Chemical composition measurements for these glasses were conducted by PSAL following the analytical plan provided in Appendix A.

Table D2 in Appendix D provides the elemental concentration measurements derived from the samples prepared using LM digestions, and Table D3 in Appendix D provides the measurements derived from the samples prepared using PF digestions. Measurements for standards (Batch 1 and a uranium standard, $\mathrm{U}_{\text {std }}$ ) that were included in the PSAL analytical plan along with the study glasses are also provided in these two tables.

The elemental concentrations were converted to oxide concentrations by multiplying the values for each element by the gravimetric factor for the corresponding oxide. During this process, an elemental concentration that was determined to be below the detection limit of the analytical procedures used by PSAL was reduced to half of that detection limit as the oxide concentration was determined.

In the sections that follow, the analytical sequences of the measurements are explored, the measurements of the standards are investigated and used for bias-correction, the measurements for each glass are reviewed, the average chemical compositions (measured and bias-corrected) for each glass are determined, and comparisons are made between the measurements and the targeted compositions for the glasses.

\subsubsection{Measurements in Analytical Sequence}

Exhibit D1 in Appendix D provides plots of the measurements generated by the PSAL for samples prepared using the LM method. The plots are in analytical sequence with different symbols and colors being used to represent each of the study and standard glasses. Similar plots for the samples prepared using the PF method are provided in Exhibit D2 in Appendix D. These plots include all of the measurement data from Tables D2 and D3. A review of these plots indicates no significant patterns or trends in the analytical process over the course of these measurements, and there appear to be no obvious outliers in these chemical composition measurements.

\subsubsection{Batch 1 and Uranium Standard Results}

In this section, the PSAL measurements of the chemical compositions of the Batch 1 and uranium standard $\left(\mathrm{U}_{\text {std }}\right)$ glasses are reviewed. These measurements are investigated across the ICP-AES analytical blocks, and the results are used to bias-correct the measurements for the study glasses.

Exhibit D3 in Appendix D provides statistical analyses of the Batch 1 and $\mathrm{U}_{\text {std }}$ results generated by the LM prep method by block for each oxide of interest. The results include analysis of variance (ANOVA) investigations looking for statistically significant differences between the block means for each of the oxides for each of the standards. The reference values for the oxide concentrations of the standard are given in the header for each set of measurements in the exhibit. The results from the statistical tests for the Batch 1 standard may be summarized as follows: $\mathrm{Na}_{2} \mathrm{O}$ and $\mathrm{ZnO}$ (a detection limit effect) had measurements that indicate a significant ICP calibration effect on the block averages at the 5\% significance level. For the $\mathrm{U}_{\text {std }}$, no oxides exhibited a significant ICP-AES calibration effect on the block averages at the $5 \%$ significance level. 
Exhibit D4 in Appendix D provides a similar set of analyses for the measurements derived from samples prepared via the PF method. Once again, the reference values for the oxide concentrations of the standard are given in the headers for each set of measurements in the exhibit. The results from the statistical tests for the Batch 1 standard may be summarized as follows: only $\mathrm{Al}_{2} \mathrm{O}_{3}$ had measurements that indicate a significant ICP-AES calibration effect on the block averages at the 5\% significance level. For the $\mathrm{U}_{\text {std }}$, only $\mathrm{U}_{3} \mathrm{O}_{8}$ had measurements that indicate a significant ICP-AES calibration effect on the block averages at the $5 \%$ significance level.

Thus, some of these results provide incentive for adjusting the measurements by the effect of the ICP-AES calibration. Therefore, the oxide measurements of the study glasses were bias-corrected for the effect of the ICP-AES calibration on each of the analytical blocks. The basis for this bias-correction is presented as part of Exhibits D3 and D4 - the average measurement for Batch 1 for each ICP-AES block for $\mathrm{Al}_{2} \mathrm{O}_{3}, \mathrm{~B}_{2} \mathrm{O}_{3}, \mathrm{BaO}, \mathrm{CaO}, \mathrm{Cr}_{2} \mathrm{O}_{3}, \mathrm{CuO}, \mathrm{Fe}_{2} \mathrm{O}_{3}, \mathrm{Li}_{2} \mathrm{O}, \mathrm{MgO}, \mathrm{MnO}, \mathrm{Na}_{2} \mathrm{O}, \mathrm{NiO}, \mathrm{SiO}_{2}$, and $\mathrm{TiO}_{2}$ and the average measurement for $\mathrm{U}_{\text {std }}$ for each ICP-AES block for $\mathrm{U}_{3} \mathrm{O}_{8}$. The Batch 1 results served as the basis for bias-correcting all of the oxides (that were bias-corrected) except uranium. The $\mathrm{U}_{\text {std }}$ results were used to bias-correct for uranium. For the other oxides, the Batch 1 results were used to conduct the biascorrection as long as the reference value for the oxide concentration in the Batch 1 glass was greater than or equal to $0.1 \mathrm{wt} \%$. No bias-correction was conducted for $\mathrm{Ce}_{2} \mathrm{O}_{3}, \mathrm{La}_{2} \mathrm{O}_{3}, \mathrm{PbO}, \mathrm{SO}_{4}, \mathrm{ThO}_{2}, \mathrm{ZnO}$, or $\mathrm{ZrO}_{2}$.

The bias-correction was conducted as follows. For each oxide, let $\bar{a}_{i j}$ be the average measurement for the $i^{\text {th }}$ oxide at analytical block $j$ for Batch 1 (or $\mathrm{U}_{\text {std }}$ for uranium), and let $t_{i}$ be the reference value for the $i^{\text {th }}$ oxide for Batch 1 (or for $\mathrm{U}_{\text {std }}$ if uranium). (The averages and reference values are provided in Exhibits D3 and D4.) Let $\bar{c}_{i j k}$ be the average measurement for the $i^{\text {th }}$ oxide at analytical block $j$ for the $k^{\text {th }}$ glass. The bias-adjustment was conducted as follows:

$$
\bar{c}_{i j k} \bullet\left(1-\frac{\bar{a}_{i j}-t_{i}}{\bar{a}_{i j}}\right)=\bar{c}_{i j k} \bullet \frac{t_{i}}{\bar{a}_{i j}}
$$

Bias-corrected measurements are indicated by a "bc" suffix, and such adjustments were performed for all of the oxides of this study except for $\mathrm{Ce}_{2} \mathrm{O}_{3}, \mathrm{La}_{2} \mathrm{O}_{3}, \mathrm{PbO}, \mathrm{SO}_{4}, \mathrm{ThO}_{2}, \mathrm{ZnO}$, and $\mathrm{ZrO}_{2}$. Both measured and measured " $\mathrm{bc}$ " values are included in the discussion that follows. In these discussions bias-corrected values for $\mathrm{Ce}_{2} \mathrm{O}_{3}, \mathrm{La}_{2} \mathrm{O}_{3}, \mathrm{PbO}, \mathrm{SO}_{4}, \mathrm{ThO}_{2}, \mathrm{ZnO}$, and $\mathrm{ZrO}_{2}$ are duplicated as the measured-bc values for completeness (i.e., to allow a sum of oxides to be computed for the bias-corrected results).

\subsubsection{Composition Measurements by Glass Number}

Exhibits D5 and D6 in Appendix D provide plots of the oxide concentration measurements by Glass ID \# (including both Batch 1, labeled as glass number 100 and $U_{\text {std, }}$ labeled as glass number 200) for the measured and bias-corrected (bc) values for the LM and PF preparation methods, respectively. Different symbols and colors are used to represent the different glasses. These plots show the individual measurements across the duplicates of each preparation method and the two ICP-AES calibrations. A review of the plots presented in these exhibits reveals the repeatability of the four individual oxide values for each glass. Some scatter exists in the $\mathrm{B}_{2} \mathrm{O}_{3}, \mathrm{Fe}_{2} \mathrm{O}_{3}, \mathrm{Na}_{2} \mathrm{O}$, and $\mathrm{SiO}_{2}$ values, though this scatter should not have a significant impact on the results presented here. No other problems are evident in these plots. More detailed discussions of the average, measured chemical compositions of the study glasses are provided in the sections that follow. 


\subsubsection{Measured versus Targeted Compositions}

The four measurements for each oxide for each glass (over both preparation methods) were averaged to determine a representative chemical composition for each glass. These determinations were conducted both for the measured and for the bias-corrected data. A sum of oxides was also computed for each glass based upon both the measured and bias-corrected values. Exhibit D7 in Appendix D provides plots showing results for each glass for each oxide to help highlight the comparisons among the measured, bias-corrected, and targeted values.

Some observations from the plots of Exhibit D7 are offered: For nearly every Frit 503/SB4 study glass, the measured $\mathrm{CaO}, \mathrm{NiO}$ and $\mathrm{ZrO}_{2}$ values are slightly less than their respective targeted and bias-corrected concentrations, and the measured $\mathrm{ThO}_{2}$ and $\mathrm{ZnO}$ concentrations are higher than their targets. For NEPHB-01, the measured $\mathrm{PbO}$ value is somewhat higher than the target. The measured $\mathrm{Fe}_{2} \mathrm{O}_{3}$ values are close to the targets for the study glasses, while the bias-corrected values are slightly below the targets. Notice that the targeted sums of oxides for the standard glasses do not sum to $100 \%$ due to an incomplete coverage of the oxides in the Batch 1 (glass \# 100) and $U_{\text {std }}$ (glass \# 200) glasses. All of the sums of oxides (both measured and bias-corrected) for the study glasses fall within the interval of 95 to $105 \mathrm{wt} \%$.

Table D4 in Appendix D provides a summary of the average and targeted compositions for the study glasses and standards. Entries in Table D4 show the relative differences between the measured or biascorrected values and the targeted values. These differences are shaded when they are greater than or equal to 5\%. Overall, these comparisons between the measured and targeted compositions suggest only minor difficulties in hitting the targeted compositions for some of the oxides (including $\mathrm{NiO}$ and $\mathrm{ThO}_{2}$ ) for some of the glasses. These should have no impact on the conclusions drawn to support the objectives of this report.

\subsection{5 $\mathrm{SO}_{4}{ }^{2-}$ retention}

Although not the primary focus of the Frit 503 study, a secondary concern is the potential need to redefine the $\mathrm{SO}_{4}{ }^{2-}$ solubility limit for SB4. The compositional analysis, coupled with the visual observations of the as-fabricated glasses (see Section 3.3.1), will serve as primary indicators to determine whether the current $0.6 \mathrm{wt} \% \mathrm{SO}_{4}{ }^{2-}$ limit (established for the Frit $418-\mathrm{SB} 3 \mathrm{system}^{37}$ ) is still applicable for SB4. From Table 2-2, the targeted $\mathrm{SO}_{4}{ }^{2-}$ concentrations in the Frit 503 glasses range from $0.401 \mathrm{wt} \%$ (NEPHB-01) to $0.669 \mathrm{wt} \%$ (NEPHB-05).

Figure 3-1 summarizes the targeted versus measured $\mathrm{SO}_{4}{ }^{2-}$ concentrations in each glass. The solid line represents the targeted concentrations as noted in Table 2-2. The x's represent the measured $\mathrm{SO}_{4}{ }^{2-}$ concentrations in the glass, while the squares are the measured, bias-corrected values. The data suggest a possible reduction in $\mathrm{SO}_{4}{ }^{2-}$ retention as WL increased. For example, at $30 \% \mathrm{WL}$ the targeted $\mathrm{SO}_{4}{ }^{2-}$ content was $\sim 0.40 \mathrm{wt} \%$ with the measured concentration being $\sim 0.38 \mathrm{wt} \%$ (a $0.02 \mathrm{wt} \%$ difference), which is within analytical uncertainties as determined by Peeler et al. ${ }^{37}$ during the Frit 418 - SB3 assessment. At $50 \% \mathrm{WL}$, the targeted $\mathrm{SO}_{4}{ }^{2-}$ content was $\sim 0.67 \mathrm{wt} \%$ with the measured concentration being $\sim 0.59 \mathrm{wt} \%$ (a $0.08 \mathrm{wt} \%$ difference). Although there does appear to be a slight reduction in the retention of $\mathrm{SO}_{4}{ }^{2-}$ at the higher WLs, the ability of the NEPHB-05 glass to retain $\sim 0.59 \mathrm{wt} \%$ in glass (which when compared to the $0.6 \mathrm{wt} \%$ PCCS value is within the $\pm 0.02 \mathrm{wt} \%$ measurements uncertainty previously defined) suggests that the $0.6 \mathrm{wt} \%$ PCCS value is still applicable. The measured values for the standard glasses are shown to be above the target (zero) due to the detection limit of the ICP-AES instrument.

In addition to the measured $\mathrm{SO}_{4}{ }^{2-}$ concentrations, no signs of a salt layer were evident on any of the Phase 3 glasses upon fabrication (visual observations are discussed in more detail in Section 3.3.1). If the $\mathrm{SO}_{4}{ }^{2-}$ concentration in the SB4 feed to DWPF contains the projected levels, then no issues with $\mathrm{SO}_{4}{ }^{2-}$ solubility are anticipated. 
WSRC-STI-2006-00009

Revision 0

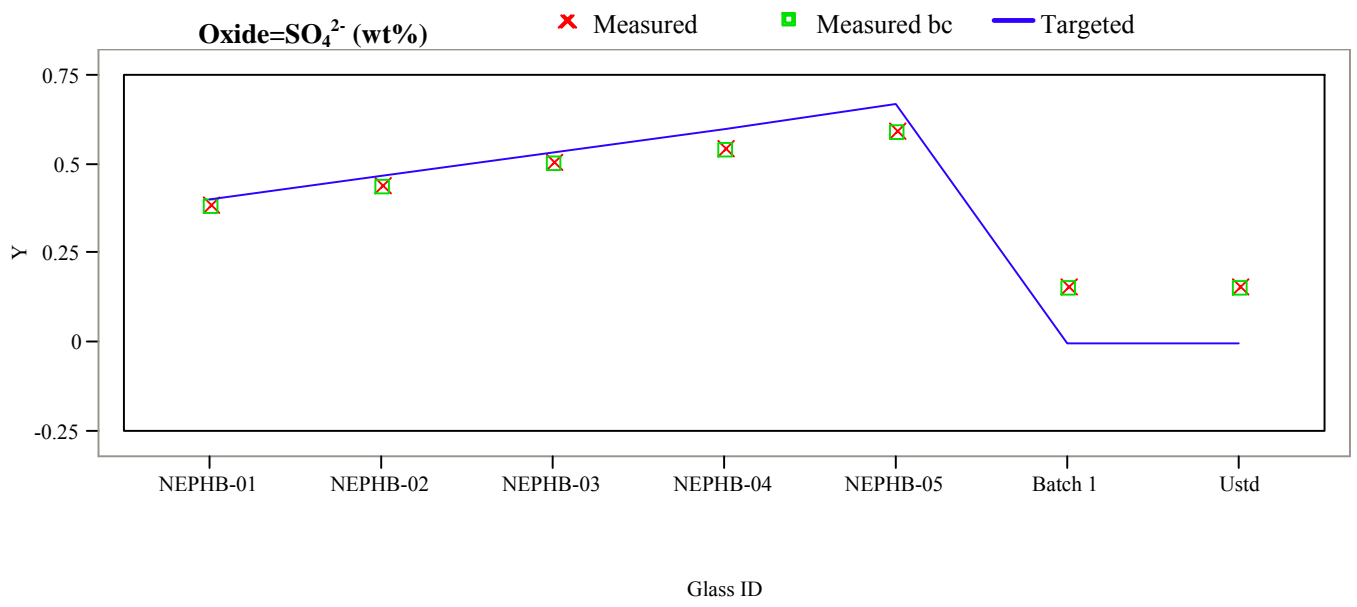

Figure 3-1. Average Measured and Bias-Corrected versus Targeted $\mathrm{SO}_{4}{ }^{2-}$ Values

\subsection{A Statistical Review of the PCT Measurements}

The Frit 503 / SB4 study glasses, after being batched and fabricated, were subjected to the 7-day $\mathrm{PCT}^{20}$ to assess their durability. Durability is the critical product quality metric for DWPF glass studies. The PCT was performed in triplicate on the quenched and ccc study glasses, the EA glass, and the ARM glass.

An analytical plan, presented in Appendix B, was provided to the PSAL to support the measurement of the compositions of the solutions resulting from the PCTs. Samples of a multi-element, standard solution were also included in the analytical plan as a check of the accuracy of the ICP-AES instrument used for these measurements. In this and the following sections, the measurements generated by the PSAL for these PCTs are presented and reviewed.

Table E1 in Appendix E provides the elemental leachate concentration measurements determined by the PSAL for the solution samples generated by the PCTs. One of the quality control checkpoints for the PCT procedure is solution-weight loss over the course of the 7-day test. None of these PCT results indicated a solution-weight loss problem. Any measurement in Table E1 below the detection limit of the analytical procedure (indicated by a "<") was replaced by $1 / 2$ of the detection limit in subsequent analyses. In addition to adjustments for detection limits, the values were adjusted for dilution. The values for the study glasses, the blanks, and the ARM glass in Table E3 were multiplied by a dilution factor of 1.6667. The values for EA were multiplied by a dilution factor of 16.6667. Table E2 in Appendix E provides the resulting dilution corrected measurements.

One of the important objectives of this study is the investigation of the effects of the heat treatment on the glass durability. In the sections that follow, the analytical sequence of the measurements is explored, the measurements of the standards are investigated and used to assess the overall accuracy of the ICP-AES measurement process, the measurements for each glass are reviewed, plots are provided that explore the effects of heat treatment on the PCTs for these glasses, the PCTs are normalized using the compositions (targeted, measured, and bias-corrected) presented in Table D4, and the normalized PCTs are compared to durability predictions for these compositions generated from the current DWPF models. ${ }^{30}$ 


\subsubsection{Measurements in Analytical Sequence}

Exhibits E1 and E2 in Appendix E provide plots of the leachate (ppm) concentrations in analytical sequence as generated by the PSAL for all of the data and for the data from only the study glasses, respectively. A different color and symbol are used for each study glass or standard. No problems are seen in these plots.

\subsubsection{Results for the Samples of the Multi-Element Solution Standard}

Exhibit E3 in Appendix E provides analyses of the PSAL measurements of the samples of the multielement solution standard by ICP-AES analytical (or calibration) block. An ANOVA investigating for statistically significant differences among the block averages for these samples for each element of interest is included in these exhibits. These results indicate a statistically significant (at approximately a $5 \%$ level) difference among only the Si average measurements over these blocks. However, no biascorrection of the PCT results for the study glasses was conducted. This approach was taken since the triplicate PCTs for a single study glass were placed in different ICP-AES blocks. Averaging the log ppm's for each set of triplicates across the blocks helps to minimize the impact of the ICP-AES calibration effects.

Table 3-1 summarizes the average measurements and the reference values for the 4 primary elements of interest. The results indicate consistent and accurate measurements from the PSAL processes used to conduct these analyses.

Table 3-1. Results from Samples of the Multi-Element Solution Standard

\begin{tabular}{|c|c|c|c|c||}
\hline $\begin{array}{c}\text { Analytical } \\
\text { Block }\end{array}$ & $\begin{array}{c}\text { Avg B } \\
\text { (ppm) }\end{array}$ & $\begin{array}{c}\text { Avg Li } \\
\text { (ppm) }\end{array}$ & $\begin{array}{c}\text { Avg Na } \\
\text { (ppm) }\end{array}$ & $\begin{array}{c}\text { Avg Si } \\
\text { (ppm) }\end{array}$ \\
\hline 1 & 19.77 & 9.44 & 82.00 & 48.33 \\
\hline 2 & 19.73 & 9.60 & 83.13 & 48.80 \\
\hline 3 & 19.93 & 9.62 & 81.07 & 50.40 \\
\hline Grand Average & 19.81 & 9.55 & 82.07 & 49.18 \\
\hline Reference Value & 20.0 & 10.0 & 81.0 & 50.0 \\
\hline \% difference & $-0.9 \%$ & $-4.5 \%$ & $1.3 \%$ & $-1.6 \%$ \\
\hline
\end{tabular}

\subsubsection{Measurements by Glass Number}

Exhibit E4 in Appendix E provides plots of the leachate concentrations for each type of submitted sample: the study glasses and the standards (EA (101), ARM (102), the multi-element solution standard (100), and blanks (103)). Exhibit E5 in Appendix E provides plots of the leachate concentrations for the PCT results of the study glasses. These plots allow for the assessment of the repeatability of the measurements, which suggests some scatter in the triplicate values for some analytes for some of the glasses. Also, note that the results from the two heat treatments are shown for each study glass and that the biggest differences between the two sets of values are evident for NEPHB-04.

\subsubsection{Normalized PCT Results}

PCT leachate concentrations are typically normalized using the cation composition (expressed as a weight percent) in the glass to obtain a grams-per-liter $(\mathrm{g} / \mathrm{L})$ leachate concentration. The normalization of the 
PCTs is usually conducted using the measured compositions of the glasses. This is the preferred normalization process for the PCTs. For completeness, the targeted cation and the bias-corrected cation compositions were also used to conduct this normalization.

As is the usual convention, the common logarithm of the normalized PCT (normalized leachate, NL) for each element of interest was determined and used for comparison. To accomplish this computation, one must

1. Determine the common logarithm of the elemental parts per million (ppm) leachate concentration for each of the triplicates and each of the elements of interest (these values are provided in Table E2 of Appendix E),

2. Average the common logarithms over the triplicates for each element of interest, and then

Normalizing Using Measured Composition (preferred method)

3. Subtract a quantity equal to 1 plus the common logarithm of the average cation measured concentration (expressed as a weight percent of the glass) from the average computed in step 2 .

Or Normalizing Using Target Composition

3. Subtract a quantity equal to 1 plus the common logarithm of the target cation concentration (expressed as a weight percent of the glass) from the average computed in step 2.

Or Normalizing Using Measured Bias-Corrected Composition

3. Subtract a quantity equal to 1 plus the common logarithm of the measured biascorrected cation concentration (expressed as a weight percent of the glass) from the average computed in step 2 .

Exhibit E6 in Appendix E provides scatter plots for these results and offers an opportunity to investigate the consistency in the leaching across the elements for the glasses of this study. All combinations of the normalizations of the PCTs (i.e., those generated using the targeted, measured, and bias-corrected compositional views) and both heat treatments are represented in the series of scatter plots. Consistency in the leaching across the elements is typically demonstrated by a high degree of linear correlation among the values for pairs of these elements. For the study glasses, the ccc results demonstrate a higher degree of correlation (smallest value is 0.9221 for $\mathrm{B}$ and $\mathrm{Na}$ responses based on the targeted compositions) than do the quenched results (smallest value is 0.6810 for $\mathrm{Na}$ and $\mathrm{Si}$ responses based on the measured and measured bias-corrected compositions). This may be due to the limited range of PCT responses for the quenched glasses as opposed to the ccc glasses as revealed by the scale of the axes of the two sets of PCT measurements in the scatter plots of Exhibit E6.

Table 3-2 summarizes the normalized PCTs for the glasses of this study. The glasses are listed by glass identifier. It should be noted that the EA elemental releases are slightly lower than those reported by Jantzen et al. ${ }^{21}$ This has been observed in previous studies and should not raise questions regarding the PCT results obtained in this study. In fact, the ARM glass is used to demonstrate control and a comparison of the ppm values obtained from the ARM (see Table E2 in Appendix E) during this study are within the control chart limits shown by Jantzen et al. ${ }^{30}$ 
Table 3-2. Normalized PCTs by Glass ID/Compositional View

\begin{tabular}{|c|c|c|c|c|c|c|c|c|c|c|}
\hline $\begin{array}{c}\text { Glass } \\
\text { ID }\end{array}$ & $\begin{array}{c}\text { Heat } \\
\text { Treatment }\end{array}$ & Composition & \begin{tabular}{|c|}
$\log \mathrm{NL}$ \\
{$[\mathrm{B}(\mathrm{g} / \mathrm{L})]$}
\end{tabular} & \begin{tabular}{|c|}
$\log \mathrm{NL}$ \\
{$[\mathrm{Li}(\mathrm{g} / \mathrm{L})]$}
\end{tabular} & $\begin{array}{c}\log \mathrm{NL} \\
{[\mathrm{Na}(\mathrm{g} / \mathrm{L})]}\end{array}$ & \begin{tabular}{|c|}
$\log \mathbf{N L}$ \\
{$[\mathrm{Si}(\mathrm{g} / \mathrm{L})]$} \\
\end{tabular} & $\begin{array}{c}\text { NL } \\
\mathrm{B}(\mathrm{g} / \mathrm{L})\end{array}$ & \begin{tabular}{|c|} 
NL \\
$\mathrm{Li}(\mathrm{g} / \mathrm{L})$ \\
\end{tabular} & $\begin{array}{c}\mathrm{NL} \\
\mathrm{Na}(\mathrm{g} / \mathrm{L}) \\
\end{array}$ & $\begin{array}{c}\text { NL } \\
\text { Si(g/L) }\end{array}$ \\
\hline ARM & $\mathrm{N} / \mathrm{A}$ & reference & \begin{tabular}{|l|}
-0.2693 \\
\end{tabular} & -0.2235 & -0.2767 & \begin{tabular}{|c|}
-0.5452 \\
\end{tabular} & 0.538 & \begin{tabular}{|l|}
0.598 \\
\end{tabular} & 0.529 & 0.285 \\
\hline EA & N/A & reference & 1.1282 & & 1.0266 & 0.4982 & 13.435 & 7.148 & 10.633 & 3.149 \\
\hline NEPHB-01 & quenched & measured & -0.1940 & -0.1239 & -0.3418 & -0.3525 & 0.640 & 0.752 & 0.455 & 0.444 \\
\hline NEPHB-01 & quenched & measured bc & -0.1779 & & & -0.3561 & 0.664 & 0.746 & 0.476 & 0.440 \\
\hline NEPHB-01 & quenched & targeted & -0.1959 & -0.1415 & -0.3298 & -0.3581 & 0.637 & 0.722 & 0.468 & 0.438 \\
\hline NEPHB-01 & $\mathrm{ccc}$ & measured & -0.2002 & -0.1504 & -0.3256 & -0.3666 & 0.631 & 0.707 & 0.473 & 0.430 \\
\hline NEPHB-01 & $\mathrm{ccc}$ & measured bc & -0.1841 & & -0.3062 & -0.3703 & 0.655 & 0.702 & 0.494 & 0.426 \\
\hline NEPHB-01 & $\mathrm{ccc}$ & targeted & -0.2021 & -0.1680 & -0.3135 & -0.3722 & 0.628 & 0.679 & 0.486 & 0.424 \\
\hline NEPHB-02 & quenched & measured & -0.1936 & & & -0.3637 & 0.640 & 0.748 & 0.522 & 0.433 \\
\hline NEPHB-02 & quenched & measured bc & -0.1774 & -0.1294 & -0.2634 & -0.3673 & 0.665 & 0.742 & 0.545 & 0.429 \\
\hline NEPHB-02 & & & & & & & 0.653 & 0.718 & 0.521 & 0.429 \\
\hline NEPHB-02 & ccc & measured & 2001 & 495 & -0.2709 & -0.3652 & 0.631 & 0.709 & 0.536 & 0.431 \\
\hline NEPHB-02 & $\mathrm{ccc}$ & measured bc & 840 & & & -0.3688 & 0.655 & 0.703 & 0.560 & 0.428 \\
\hline NEPHB-02 & $\mathrm{ccc}$ & targeted & 919 & 674 & 711 & 686 & 0.643 & 0.680 & 0.536 & 0.428 \\
\hline NEPHB-03 & quenched & measured & 519 & 186 & -0.2160 & -0.3592 & 0.705 & 0.761 & 0.608 & 0.437 \\
\hline NEPHB-03 & quenched & measured bc & 358 & & -0.1967 & -0.3628 & 0.731 & 0.755 & 0.636 & 0.434 \\
\hline NEPHB-03 & quenched & & -0.1467 & 349 & & -0.3602 & 0.713 & 0.733 & 0.613 & 0.436 \\
\hline NEPHB-03 & $\mathrm{ccc}$ & measured & -0.1637 & 265 & & 615 & 0.686 & 0.747 & 0.597 & 0.435 \\
\hline NEPHB-03 & $\mathrm{ccc}$ & measured bc & 1476 & & & -0.3651 & 0.712 & 0.742 & 0.624 & 0.431 \\
\hline NEPHB-03 & & & & & & & & 0.720 & & 0.434 \\
\hline NEPHB-04 & quenched & measured & -0.1376 & & & 3555 & 0.728 & 0.761 & 0.722 & 0.441 \\
\hline NEPHB-04 & quenched & measured bc & -0.1215 & 1221 & -0.1221 & -0.3591 & 0.756 & 0.755 & 0.755 & 0.437 \\
\hline NEPHB-04 & quenched & targeted & -0.1076 & 1148 & -0.1323 & -0.3515 & 0.781 & 0.768 & 0.737 & 0.445 \\
\hline NEPHB-04 & $\mathrm{ccc}$ & & 0.0772 & 0.0597 & -0.0466 & -0.2984 & 1.195 & 1.147 & 0.898 & 0.503 \\
\hline NEPHB-04 & $\mathrm{ccc}$ & measured bc & 0.0934 & 0.0564 & -0.0272 & -0.3021 & 1.240 & 1.139 & 0.939 & 0.499 \\
\hline NEPHB-04 & $\mathrm{ccc}$ & & 0.1072 & 0.0637 & -0.0374 & -0.2944 & 1.280 & 1.158 & 0.918 & 0.508 \\
\hline NEPHB-05 & quenched & measured & -0.0548 & -0.0731 & & -0.3233 & 0.882 & 0.845 & 0.846 & 0.475 \\
\hline NEPHB-05 & quenched & measured bc & -0.0387 & -0.0764 & -0.0530 & -0.3269 & 0.915 & 0.839 & 0.885 & 0.471 \\
\hline NEPHB-05 & quenched & targeted & -0.0536 & -0.0893 & -0.0603 & -0.3258 & 0.884 & 0.814 & 0.870 & 0.472 \\
\hline NEPHB-05 & $\mathrm{ccc}$ & measured & -0.0949 & -0.0636 & -0.1203 & -0.3373 & 0.804 & 0.864 & 0.758 & 0.460 \\
\hline NEPHB-05 & $\mathrm{ccc}$ & measured bc & -0.0788 & -0.0669 & -0.1009 & -0.3409 & 0.834 & 0.857 & 0.793 & 0.456 \\
\hline NEPHB-05 & $\mathrm{ccc}$ & targeted & -0.0937 & -0.0797 & -0.1082 & -0.3399 & 0.806 & 0.832 & 0.780 & 0.457 \\
\hline
\end{tabular}

\subsubsection{Effects of Heat Treatment on PCTs}

Exhibit E7 in Appendix E provides a series of plots and statistical comparisons that show the effects of heat treatment on the common logarithm ppm-responses of interest on the triplicate PCTs for each element for each study glass. The ccc version of a given glass yielded measurements indicating a significantly (at the 5\% significance level) larger mean $\log (\mathrm{ppm})$ response than the quenched version of the glass for a given element if the Prob>t value in the exhibit is 0.05 or smaller. This was the outcome for all 4 elements (B, Li, Na, and Si) for NEPHB-04. No other glass had any element for which the ccc version had a statistically greater mean than the quenched version.

Exhibit E8 in Appendix E provides a series of plots that show the effects of heat treatment on the PCT response based on the three different compositional views: measured, measured bias-corrected, and targeted. These plots allow for an assessment of the differences in PCT responses from a practical perspective and show, once again, that the PCT responses for the ccc version of NEPHB-04 were greater than their quenched counterparts. The normalized releases for boron, based on the measured compositions, are shown graphically in Figure 3-2 below. The PCT responses are indicated by the symbol $(\square)$ for the quenched glasses and the symbol $(\bullet)$ for the ccc glasses. 


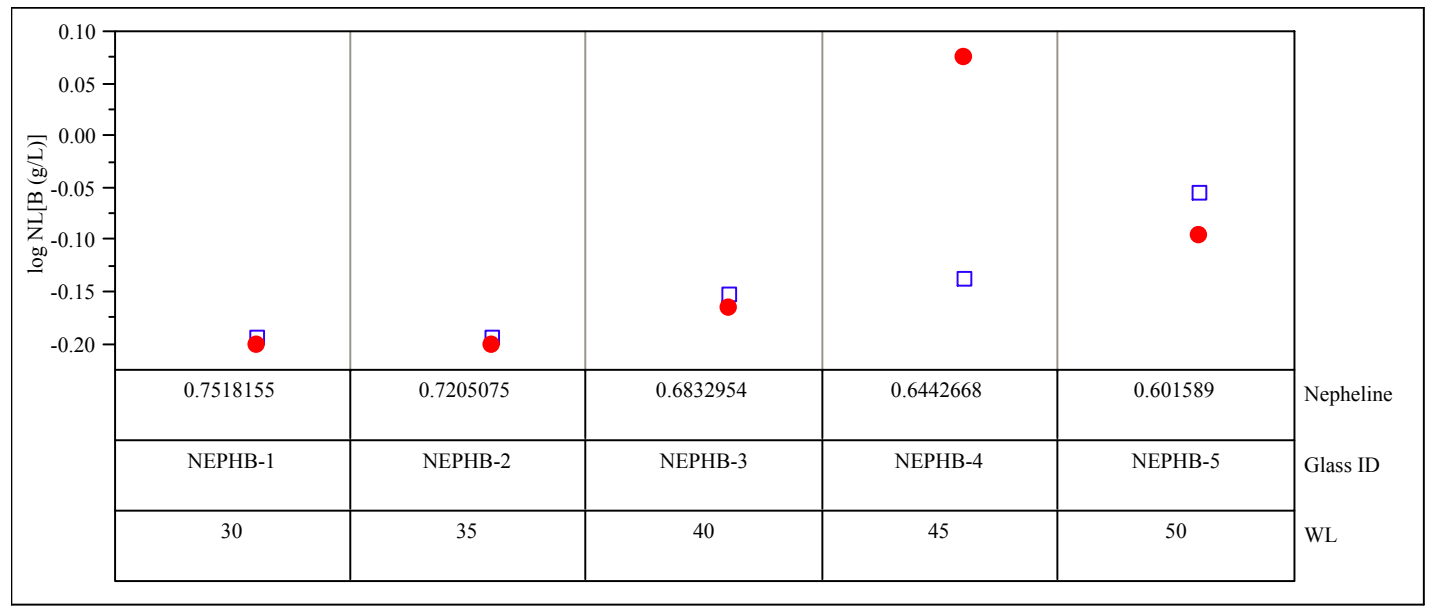

Figure 3-2. Normalized releases for boron, based on the measured compositions, for the Frit 503 glasses.

It was expected that the ccc version of NEPHB-05 would show the highest NL [B] due to its relatively high WL (50\%) and its nepheline discriminator value of 0.60 , which is below the critical value of 0.62 . However, the NEPHB-05 glass, along with NEPHB-01, NEPHB-02 and NEPHB-03, showed little or no difference in NL [B] between the quenched and ccc versions of the glass. The highest NL [B] for the ccc version of NEPHB-04 (1.280 g/L based on targeted composition) is more than an order of magnitude below that of the EA glass $(16.695 \mathrm{~g} / \mathrm{L}),{ }^{21}$ so the difference in PCT response between the quenched and ccc versions of this glass, while curious from an experimental standpoint, presents no practical impact to processing at DWPF.

The results shown in Figure 3-2 may also indicate that the test solutions were reversed in the laboratory for NEPHB-04ccc and NEPHB-05ccc. A comparison of the target and measured compositions indicated that the glasses were not switched during the batching process. To test the potential that the PCT solutions may have been switched or mislabeled, the PCT was performed again for the ccc versions of the five Frit 503 glasses (i.e., archival specimens of each quenched glass from the original batching and melting process were re-heat treated, ground, and the PCT performed according to procedure). A second analytical plan was issued for this task, and is included as Appendix C. The results for the "re-tested" ccc glasses are included in Appendix E.

Table E3 in Appendix E provides the elemental leachate concentration measurements determined by the PSAL for the solution samples generated by the re-tested PCTs. None of these PCT results indicated a solution-weight loss problem. Consistent with earlier data, any measurement below the detection limit of the analytical procedure (indicated by a "<") was replaced by $1 / 2$ of the detection limit in subsequent analyses. In addition to adjustments for detection limits, the values were adjusted for dilution. The values for the study glasses, the blanks, and the ARM glass in Table E3 were multiplied by a dilution factor of 1.6667 to determine the values in parts per million (ppm). The values for EA were multiplied by a dilution factor of 16.6667. Table E4 in Appendix E provides the resulting measurements.

Exhibit E9 in Appendix E indicates that the ccc version of NEPHB-04 was again shown to have higher releases than the other Frit 503 glasses. The re-tested PCTs indicate that no mishandling of samples occurred during the original PCTs. Therefore, the original PCT results were considered valid. Again, the NL [B] for the ccc version of NEPHB-04 is well below that of EA and does not present a concern for DWPF with respect to durability. 


\subsubsection{Predicted versus Measured PCTs}

Exhibit E10 in Appendix E provides plots of the DWPF models that relate the logarithm of the normalized PCT (for each element of interest) to a linear function of a free energy of hydration term $\left(\Delta \mathrm{G}_{\mathrm{P}}\right.$, $\mathrm{kcal} / 100 \mathrm{~g}$ glass) derived from all of the glass compositional views and heat treatments. ${ }^{30}$ Prediction limits (at a 95\% confidence) for an individual PCT result are also plotted along with the linear fit. The EA and ARM-1 results are also indicated on these plots. Exhibit E11 in Appendix E provides a version of these plots for the quenched glasses only, while Exhibit E12 in Appendix E provides a version for ccc glasses only.

All of the quenched glasses and all but one of the ccc glasses show acceptable and predictable PCT responses. For NEPHB-04ccc, the B response shows an acceptable (NL [B] of $1.28 \mathrm{~g} / \mathrm{L}$ ) yet not predictable PCT value for the targeted and measured bias-corrected compositional views. Note that the $\Delta \mathrm{G}_{\mathrm{P}}$ value for this glass is more toward the positive-end of the range of values typically covered for $\Delta \mathrm{G}_{\mathrm{P}}$. The unpredictability of this particular glass is not a concern, since glasses in the more positive $\Delta \mathrm{G}_{\mathrm{P}}$ range have been observed to fall outside the upper $95 \%$ confidence band while still having an acceptable durability. ${ }^{38}$

\subsubsection{Values of the Nepheline Constraint and Predictability}

Li et al. proposed 0.62 as the critical value for the nepheline discriminator. ${ }^{15}$ Glass compositions with a nepheline discriminator value of less than 0.62 are prone to nepheline crystallization. ${ }^{15}$ Table 3-3 provides the nepheline constraint values for each study glass for each compositional view. Note that only NEPHB-05 fails to satisfy the constraint. However, as will be shown below, nepheline crystallization did not occur (to an extent detectible by XRD) in this glass. Also, the PCT responses do not indicate significant nepheline crystallization for NEPHB-05. These results indicate that it would be useful to assess the measurement uncertainty associated with the nepheline discriminator. The uncertainty of the critical nepheline discriminator value will be important if the nepheline discriminator is to be included in DWPF process controls.

Table 3-3. Nepheline Constraint Values by Composition View

\begin{tabular}{||c|c|c|c|c||}
\hline WL & Glass ID & measured & measured bc & targeted \\
\hline 30 & NEPHB-01 & 0.752 & 0.756 & 0.759 \\
\hline 35 & NEPHB-02 & 0.721 & 0.725 & 0.723 \\
\hline 40 & NEPHB-03 & 0.683 & 0.688 & 0.685 \\
\hline 45 & NEPHB-04 & 0.644 & 0.649 & 0.646 \\
\hline 50 & NEPHB-05 & 0.602 & 0.606 & 0.606 \\
\hline
\end{tabular}

\subsection{Homogeneity}

In this section, the primary interest is the possible formation of nepheline (and/or other crystalline phases) in the Frit $503 \mathrm{ccc}$ glasses, which could be responsible for the measurable differences in PCT responses as compared to their quenched counterparts. Table 3-4 summarizes the visual and XRD results for the quenched and ccc Frit 503 glasses. It should be noted that only the ccc versions of the glasses were submitted for XRD analysis given that the visual observations and durability responses suggested no significant crystallization in the quenched glasses. That is, with normalized boron releases ranging from $0.64 \mathrm{~g} / \mathrm{L}$ to $0.92 \mathrm{~g} / \mathrm{L}$, there is no evidence of nepheline formation in the quenched glasses - even if present, the impact is of no practical concern. 
Prior to discussing the results, a few words regarding the terminology used in the tables are warranted. The use of "homogeneous" for visual observations indicates that the sample was classified as a singlephase system (i.e., no evidence of crystallization). The term "surface crystals" (used as a descriptor for visual observations) implies that the surface of the glass was characterized by the presence of crystallization while the cross-section of bulk glass appeared homogeneous (i.e., single-phase, black and shiny). Surface crystallization in the Frit 503 glasses was apparent through the presence of a "textured" surface that ranged in appearance from a "dull or matte" surface to a "highly metallic-like" surface.

The XRD results are more qualitative in nature. As previously mentioned, only the ccc glasses were submitted for XRD analysis based on both the PCT responses as well as visual observations of the quenched glasses. The PCT responses of the quenched glasses were "acceptable and predictable" and visual observations suggested only the presence of surface devitrification on the higher WL glasses. Historically, surface devitrification occurs as WLs increase, and this is typically the result of spinel formation for DWPF type glasses. The Frit 503 PCT responses suggested that for those quenched glasses that were classified as having "metallic swirls on the surface", spinel formation was highly probable, which is consistent with historical and recent observations and the inert effect on the PCT response. For the ccc glasses, the XRD results suggested that the glass was either amorphous or contained some degree of crystallization. The presence of a characteristically high background devoid of crystalline spectral lines indicates that the glass product is amorphous (suggesting either a completely amorphous product or that the degree of crystallization is below the detection limit - approximately $0.5 \mathrm{vol} \%$ in glass). In terms of crystallization, the XRD results indicated the presence of spinel (Trevorite, $\mathrm{NiFe}_{2} \mathrm{O}_{4}$ ). Nepheline $\left(\mathrm{NaAlSiO}_{4}\right)$ was not present at a detectible level in these glasses. For a more detailed description of the visual observations and XRD results of both the quenched and ccc glasses, see WSRC-NB-2006-00016 (pages $77-78$ ).

\subsubsection{Visual Observations}

Visual observations of the quenched Frit 503 glasses indicate that four of the glasses were homogeneous, while NEPHB-05 was characterized by metallic swirls on the surface with the bulk (cross-section) being homogeneous. The noted surface crystallization on the quenched, high WL glass (NEPHB-05) is consistent with historical, visual observations of DWPF-based glasses, especially those targeting higher waste loadings. More specifically, use of descriptions such as a dull or matte texture and/or metallic-like surface is common for DWPF-type glasses targeting higher WLs and/or having undergone a slow cooling schedule. Previous XRD analyses have indicated that the textured or metallic-like surfaces are typically a result of spinels that precipitate during the cooling process. This is in-line with glass theory which suggests that as WL increases, the concentrations of sludge components such as $\mathrm{Fe}_{2} \mathrm{O}_{3}, \mathrm{NiO}, \mathrm{Cr}_{2} \mathrm{O}_{3}$, and/or $\mathrm{MnO}$ also increase, enhancing the likelihood of spinel devitrification. Based on the PCT responses for the quenched glasses, spinel formation resulting in the metallic haze is reasonable as spinels have been shown to have no impact on the durability response. ${ }^{4}$

A metallic haze, either somewhat shiny or dull, characterized the surface of four of the ccc glasses, with NEPHB-01 (at the lowest WL) being the exception. The primary difference among the ccc glasses is the degree of devitrification visually observed within the bulk glass. That is, when examining the crosssections of the heat treated samples, visual observations ranged from "clean, black and shiny" (indicating a homogeneous glass) to "crystals throughout". The transition from homogeneous to partially devitrified and completely devitrified resulted as WL increased. In general, visual observations indicate that devitrification was more prevalent in the ccc glasses than in the quenched glasses, as expected, given kinetics are more favorable for devitrification during the slower cooling cycle. 
Table 3-4. Visual observations and XRD results for the Frit 503 glasses.

\begin{tabular}{|c|c|c|c|c||}
\hline Glass & $\begin{array}{c}\text { Target } \\
\text { WL }\end{array}$ & $\begin{array}{c}\text { Heat } \\
\text { treatment }\end{array}$ & Visual Observations \\
\hline NEPHB-01 & 30 & quenched & Patty - clean, black and shiny, homogeneous; Crucible - clean with bubbles & XRD Results \\
\hline NEPHB-01 & 30 & ccc & Surface - clean, black and shiny; Bulk - clean, black and shiny & amorphous \\
\hline NEPHB-02 & 35 & quenched & Patty - clean, black and shiny, homogeneous; Crucible - clean with bubbles & - \\
\hline NEPHB-02 & 35 & ccc & Surface - shiny, metallic haze; Bulk - clean & amorphous \\
\hline NEPHB-03 & 40 & quenched & Patty - clean, black and shiny, homogeneous; Crucible - clean with bubbles & - \\
\hline NEPHB-03 & 40 & ccc & Surface - shiny metallic haze with spots of crystals; Bulk - clean \\
\hline NEPHB-04 & 45 & quenched & Patty - one spot of undissolved material in bulk, otherwise clean; Crucible - one spot of & - \\
\hline NEPHB-04 & 45 & ccc & Surface - duller metallic haze with spots of crystals; Bulk - shiny, some crystals & NiFe ${ }_{2} \mathrm{O}_{4}$ \\
\hline NEPHB-05 & 50 & quenched & $\begin{array}{c}\text { Patty - small amount of metallic swirls on surface, bulk clean; Crucible - one spot of } \\
\text { undissolved material, otherwise clean }\end{array}$ & - \\
\hline NEPHB-05 & 50 & ccc & Surface - dull, matte, crystals across most of surface; Bulk - crystals throughout & NiFe $_{2} \mathrm{O}_{4}$ \\
\hline
\end{tabular}




\subsubsection{XRD Results}

XRD results indicated that the low WL glasses (i.e., 30 to $40 \mathrm{wt} \%$ ) were amorphous. This agrees well with the PCT data, in that no statistical or practical difference in NL [B] response was seen between the quenched and ccc versions of NEPHB-01, NEPHB-02 and NEPHB-03. The higher WL ccc glasses (45\% and $50 \% \mathrm{WL}$ ) were shown by XRD to contain spinel (trevorite, $\mathrm{NiFe}_{2} \mathrm{O}_{4}$ ). Previous work has shown that spinels do not have a negative impact on durability, ${ }^{11}$ so this is likely not the cause of the higher NL [B] measured for the ccc version of NEPHB-04. While the data collected in this study are not sufficient to elucidate the cause of this higher PCT response, it is again of little practical concern as the NL [B] for NEPHB-04 (1.280 g/L based on targeted composition) is more than an order of magnitude below that of the EA glass $(16.695 \mathrm{~g} / \mathrm{L}){ }^{21}$ 


\subsection{Conclusions}

The results of this study concur with the earlier nepheline crystallization studies (Phases 1 through 3 ) in that a nepheline discriminator of 0.62 appears to be the appropriate value for screening out glasses with the potential for nepheline crystallization upon slow cooling. Further discussion of the nepheline discriminator and a recommendation for its inclusion in DWPF process controls will be addressed in a forthcoming report.

Chemical composition measurements indicated that the experimental glasses were close to their target compositions. PCT results showed that all of the Fit 503 quenched glasses were acceptable as compared with the EA reference glass. The durability of one of the ccc glasses, NEPHB-04, was statistically greater than its quenched counterpart. However, this was not driven by nepheline crystallization and was shown to be of little practical significance, as the durability of the NEPHB-04 ccc glass was also well below that of the EA reference glass. The PCT response of this glass was also unpredictable by the model but historically, glasses in the more positive $\Delta \mathrm{G}_{\mathrm{P}}$ range falling outside the upper $95 \%$ confidence band have been observed. ${ }^{38}$

Visual observations and PCT results indicated that all of the Frit 503 quenched glasses were amorphous. For the ccc glasses, XRD results indicated that the lower WL glasses (30 to $40 \mathrm{wt} \%$ ) were amorphous, which was consistent with visual observations and the similarity in PCT responses. The higher WL glasses (40 and $50 \mathrm{wt} \%$ ) were shown by XRD to contain spinel (trevorite, $\mathrm{NiFe}_{2} \mathrm{O}_{4}$ ). It is possible that some of the other high WL glasses also contained some nepheline, but that the amount of nepheline crystallization was below the detection limit associated with XRD.

With respect to frit selection for SB4, the results indicate that Frit 503 is a good candidate for SB4 processing, based on PCT responses for both quenched and ccc glasses over a WL range of $30-50 \%$. It should be noted that the higher WL glasses would not be processable in DWPF as they exceed other process related criteria (such as $\mathrm{T}_{\mathrm{L}}$ ). However, melt rate and the final SB4 composition projection are also important factors in frit selection. Additional melt rate studies are currently underway, and the final composition projection for SB4 is expected shortly. 
WSRC-STI-2006-00009

Revision 0

This page intentionally left blank. 


\subsection{Recommendations}

The path forward for evaluating the impact of nepheline formation on SB4-based glasses should include an assessment of the impact of implementing a nepheline discriminator value of 0.62 as part of PCCS at DWPF, based on the results of the Phase $1-3$ studies and the Frit 503 study. A determination should be made as to whether the nepheline discriminator would be effective in screening out glasses that are either unacceptable (based on PCT responses) and/or unpredictable (using the $\Delta \mathrm{G}_{\mathrm{P}}$ models).

In addition, the impact of measurement uncertainty (MAR) on the projected operating windows for the frit-SB4 systems of interest must be made. The nepheline discriminator value of 0.62 does not yet have a measurement uncertainty associated with it. An assessment must be made to determine whether the inclusion of measurement uncertainty in the nepheline discriminator will restrict the range of WLs available to DWPF.

The impact of applying a nepheline discriminator to process controls must be evaluated for glasses that have already been fabricated at DWPF. Future work should identify what impact, if any, implementation of the nepheline discriminator would have on acceptability of historical glass compositions.

Finally, Li et al ${ }^{15}$ suggest that $\mathrm{B}_{2} \mathrm{O}_{3}$ suppresses nepheline formation based on a structural role or competition with $\mathrm{Al}_{2} \mathrm{O}_{3}$ for $\mathrm{Na}_{2} \mathrm{O}$ in the borosilicate glass network. More specifically, $\mathrm{B}_{2} \mathrm{O}_{3}$ tends to lower the activity of $\mathrm{Na}_{2} \mathrm{O}$ in the melt which restricts or reduces the amount of $\mathrm{Na}_{2} \mathrm{O}$ available to form nepheline. That being said, it is interesting to note that $\mathrm{B}_{2} \mathrm{O}_{3}$ is not associated with the nepheline discriminator proposed by Li et al. ${ }^{15}$ Although the experimental results from the nepheline studies associated with SB4 have shown that the 0.62 nepheline value is effective, perhaps the effect of $\mathrm{B}_{2} \mathrm{O}_{3}$ may improve this predictive tool. 
WSRC-STI-2006-00009

Revision 0

This page intentionally left blank. 
WSRC-STI-2006-00009

Revision 0

\subsection{References}

1. Brown, K. G., R. L. Postles and T. B. Edwards, SME Acceptability Determination for DWPF Process

Control, WSRC-TR-95-00364, Revision 4, Westinghouse Savannah River Company, Aiken, South Carolina (2002).

2. Jantzen, C. M. and K. G. Brown, "Predicting the Spinel-Nepheline Liquidus for Application to Nuclear Waste Glass Processing: Part I. Primary Phase Analysis, Liquidus Measurement, and Quasicrystaline Approach," J. Am. Ceram. Soc., in press (2006).

3. Jantzen, C. M. and K. G. Brown, "Predicting the Spinel-Nepheline Liquidus for Application to Nuclear Waste Glass Processing: Part II. Quasicrystalline Freezing Point Depression Model," J. Am. Ceram. Soc., in press (2006).

4. Bickford, D. F. and C. M. Jantzen, "Devitrification of SRL Defense Waste Glass," Sci. Basis for Nuclear Waste Management VII, edited by G. L. McVay. Elsevier, New York, pp. 557-565 (1984).

5. Bickford, D. F. and C. M. Jantzen, "Devitrification of Defense Nuclear Waste Glasses: Role of Melt Insolubles," J. Non-Crystalline Solids, 84 [1-3] 299-307 (1986).

6. Jantzen, C. M., D. F. Bickford, D. G. Karraker and G. G. Wicks, "Time-Temperature-Transformation Kinetics in SRL Waste Glass," pp. 30-38 in Advances in Ceramics, Vol. 8, American Ceramic Society, Westerville, OH (1984).

7. Spilman, D. B., L. L. Hench and D. E. Clark, "Devitrification and Subsequent Effects on the Leach Behavior of a Simulated Borosilicate Nuclear Waste Glass," Nuclear and Chemical Waste Management, 6 107-119 (1986).

8. Marra, S. L. and C. M. Jantzen, Characterization of Projected DWPF Glass Heat Treated to Simulate Canister Centerline Cooling, WSRC-TR-92-142, Revision 1, Westinghouse Savannah River Company, Aiken, South Carolina (1993).

9. Li, H., J. D. Vienna, P. Hrma, D. E. Smith and M. J. Schwieger, "Nepheline Precipitation in High-Level Waste Glasses - Compositional Effects and Impact on the Waste Form Acceptability," Mat. Res. Soc. Proc., Vol. 465, pp. 261-268 (1997).

10. Riley, B. J., J. A. Rosario and P. Hrma, Impact of HLW Glass Crystallinity on the PCT Response, PNNL13491, Pacific Northwest National Laboratory, Richland, Washington (2001).

11. Jantzen, C. M. and D. F. Bickford, "Leaching of Devitrified Glass Containing Simulated SRP Nuclear Waste," pp. 135-146 in Sci. Basis for Nuclear Waste Management, Vol. 8, J. A. Stone and R. C. Ewing, eds. Materials Research Society, Pittsburgh, PA (1985).

12. Cicero, C. A., S. L. Marra and M. K. Andrews, Phase Stability Determinations of DWPF Waste Glasses (U), WSRC-TR-93-00227, Revision 0, Westinghouse Savannah River Company, Aiken, South Carolina (1993).

13. Kim, D. S., D. K. Peeler and P. Hrma, "Effect of Crystallization on the Chemical Durability of Simulated Nuclear Waste Glasses," Environmental Issues and Waste Management Technologies in the Ceramic and Nuclear Industries, Vol. 61, pp. 177-185 (1995).

14. Lilliston, G. R., Development of Elemental Sludge Compositions for Variations of Sludge Batch 4 (SB4), CBU-PIT-2004-00011, Revision 1, Westinghouse Savannah River Company, Aiken, South Carolina (2005).

15. Li, H., P. Hrma, J. D. Vienna, M. Qian, Y. Su and D. E. Smith, "Effects of $\mathrm{Al}_{2} \mathrm{O}_{3}, \mathrm{~B}_{2} \mathrm{O}_{3}, \mathrm{Na}_{2} \mathrm{O}$, and $\mathrm{SiO}_{2}$ on Nepheline Formation in Borosilicate Glasses: Chemical and Physical Correlations," J. Non-Crystalline Solids, 331 202-216 (2003).

16. Peeler, D. K. and T. B. Edwards, Frit Development Efforts for Sludge Batch 4: Model-Based Assessments, WSRC-TR-2005-00103, Revision 0, Westinghouse Savannah River Company, Aiken, South Carolina (2005). 
17. Peeler, D. K. and T. B. Edwards, Model Based Assessments for the Baseline Sludge Batch 4 (Case 15C) Flowsheet, WSRC-TR-2006-00049, Revision 0, Washington Savannah River Company, Aiken, South Carolina (2006).

18. Peeler, D. K., T. B. Edwards and T. H. Lorier, Nepheline Formation Potential in Sludge Batch (SB4) Glasses, WSRC-TR-2005-00153, Revision 0, Westinghouse Savannah River Company, Aiken, South Carolina (2005).

19. Peeler, D. K., T. B. Edwards, I. A. Reamer and R. J. Workman, Nepheline Formation Study for Sludge Batch 4 (SB4): Phase 1 Experimental Results, WSRC-TR-2005-00371, Revision 0, Westinghouse Savannah River Company, Aiken, South Carolina (2005).

20. ASTM, Standard Test Methods for Determining Chemical Durability of Nuclear Waste Glasses: The Product Consistency Test (PCT), ASTM C-1285-2002, (2002).

21. Jantzen, C. M., N. E. Bibler, D. C. Beam, C. L. Crawford and M. A. Pickett, Characterization of the Defense Waste Processing Facility (DWPF) Environmental Assessment (EA) Glass Standard Reference Material, WSRC-TR-92-346, Revision 1, Westinghouse Savannah River Company, Aiken, South Carolina (1993).

22. Elder, H. H., Estimate of Sludge Batch 4 Calcine Composition, CBU-PIT-2005-00134, Revision 0, Westinghouse Savannah River Company, Aiken, South Carolina (2005).

23. Elder, H. H., Estimate of Sludge Batch 4 Calcine Composition Additional Cases, CBU-PIT-2005-00176, Revision 0, Westinghouse Savannah River Company, Aiken, South Carolina (2005).

24. Peeler, D. K. and T. B. Edwards, Frit Development Effort for SB4: Nominal and Variation Stage Assessments, WSRC-TR-2005-00372, Revision 0, Westinghouse Savannah River Company, Aiken, South Carolina (2005).

25. Peeler, D. K., T. B. Edwards, D. R. Best, I. A. Reamer and R. J. Workman, Nepheline Formation Study for Sludge Batch 4 (SB4): Phase 2 Experimental Results, WSRC-TR-2006-00006, Revision 0, Westinghouse Savannah River Company, Aiken, South Carolina (2006).

26. Edwards, T. B. and D. K. Peeler, Nepheline Formation Potential in Sludge Batch 4 (SB4) and Its Impact on Durability: Selecting Glasses for a Phase 2 Study, WSRC-TR-2005-00370, Revision 0, Westinghouse Savannah River Company, Aiken, South Carolina (2005).

27. Fox, K. M., T. B. Edwards and D. K. Peeler, Nepheline Formation Potential in Sludge Batch 4 (SB4) and Its Impact on Durability: Selecting Glases for a Phase 3 Study, WSRC-TR-2006-00053, Revision 0, Washington Savannah River Company, Aiken, South Carolina (2006).

28. Shah, H. B., Estimate of Sludge Batch 4 Calcine Composition: Additional Cases for Final Recommendation, CBU-PIT-2006-0001, Westinghouse Savannah River Company, Aiken, South Carolina (2006).

29. Fox, K. M., D. K. Peeler, T. B. Edwards, D. R. Best, I. A. Reamer and R. J. Workman, Nepheline Formation Study for Sludge Batch 4 (SB4): Phase 3 Experimental Results, WSRC-TR-2006-00093, Revision 0, Washington Savannah River Company, Aiken, South Carolina (2006).

30. Jantzen, C. M., J. B. Picket, K. G. Brown, T. B. Edwards and D. C. Beam, Process/Product Models for the Defense Waste Processing Facility (DWPF): Part I. Predicting Glass Durability from Composition Using a Thermodynamic Hydration Energy Reaction Model (THERMO), WSRC-TR-93-672, Revision 1, Westinghouse Savannah River Company, Aiken, South Carolina (1995).

31. Peeler, D. K. and T. B. Edwards, $\mathbf{H i g h} \mathbf{B}_{2} \mathbf{O}_{3} / \mathbf{F e}_{2} \mathbf{O}_{3}$-based Frits: MAR Assessments for Sludge Batch 4 (SB4), WSRC-TR-2006-00181, Revision 0, Washington Savannah River Company, Aiken, South Carolina (2006). 
32. Washburn, F. A., Technical Task Request: Sludge Batch $\mathbf{4}$ and MCU Frit Optimization, HLW/DWPF/TTR2004-0025, Revision 0, Westinghouse Savannah River Company, Aiken, South Carolina (2004).

33. Peeler, D. K., Task Technical \& QA Plan: Sludge Batch and MCU Frit Optimization, WSRC-RP-200400746, Revision 0, Westinghouse Savannah River Company, Aiken, South Carolina (2004).

34. Peeler, D. K. and T. B. Edwards, Model Based Assessments for SB4 Washing Options: 1.2M Batch/0.91M Blend and 1.4M Batch/0.96M Blend, WSRC-STI-2006-00006, Revision 0, Washington Savannah River Company, Aiken, South Carolina (2006).

35. SRNL, Glass Batching, SRTC Procedure Manual, L29, ITS-0001, Westinghouse Savannah River Company, Aiken, South Carolina (2002).

36. SRNL, Glass Melting, SRTC Procedure Manual, L29, ITS-0003, Westinghouse Savannah River Company, Aiken, South Carolina (2002).

37. Peeler, D. K., C. C. Herman, M. E. Smith, T. H. Lorier, D. R. Best, T. B. Edwards and M. A. Baich, An Assessment of the Sulfate Solubility Limit for the Frit 418 - Sludge Batch 2/3 System, WSRC-TR-2004-00081, Revision 0, Westinghouse Savannah River Company, Aiken, South Carolina (2004).

38. Harbour, J. R., T. B. Edwards and R. J. Workman, Summary of Results for Macrobatch 3 Variability Study, WSRC-TR-2000-00351, Revision 0, Westinghouse Savannah River Company, Aiken, South Carolina (2000). 
WSRC-STI-2006-00009

Revision 0

Appendix A (SRNL-SCS-2006-00014)

This page intentionally left blank. 


\section{Appendix A}

\section{An Analytical Plan for Measuring the Chemical Compositions of Five Frit 503/SB4 Glasses (U)}

(SRNL-SCS-2006-00014) 
WSRC-STI-2006-00009

Revision 0

Appendix A (SRNL-SCS-2006-00014)

This page intentionally left blank. 
April 7, 2006

To:

K. M. Fox, SRNL

cc:
R. A. Baker, 773-42A
D. R. Best, 786-1A (wo)
C. C. Herman, 999-W
D. K. Peeler, 999-W

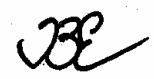

From: T. B. Edwards, 773-42A (5-5148)

Statistical Consulting Section
I. A. Reamer, 999-1W

P. A. Toole, 786-1A (wo)

R. C. Tuckfield, 773-42A

R. J. Workman, 999-1W

\section{wo - without glass identifiers}

Rodolekaker

R. A. Baker, Technical Reviewer.

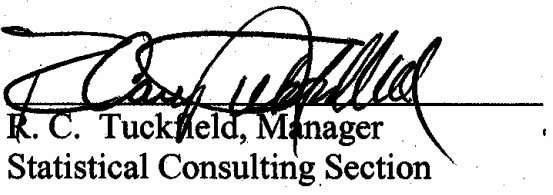

$\frac{4 / 17 / 2006}{\text { Date }}$

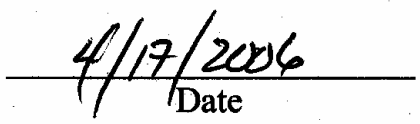

\section{An Analytical Plan for MEASURING THE CHEMICAL COMPOSITIONS OF FIVE FRIT 503/SB4 GLASSES (U)}


WSRC-STI-2006-00009

Revision 0

Appendix A (SRNL-SCS-2006-00014)

\subsection{EXECUTIVE SUMMARY}

Frit development efforts are underway at the Savannah River National Laboratory (SRNL) to support the processing of Sludge Batch 4 (SB4) at the Defense Waste Processing Facility (DWPF). One of the candidate frits considered during the recent assessments of the baseline preparation plan (Case 15C) was Frit 503, which was called Frit 418-m10 in the assessment. To provide experimental results to support the evaluation of this frit with SB4, five glasses have been fabricated for durability testing. Testing the durability of these glasses will also complement SRNL's ongoing nepheline studies by providing additional insight into the ability of the nepheline discriminator to predict the occurrence of a nepheline primary crystalline phase for SB4 glasses and into the impact of nepheline on the durability of the SB4 glasses.

The chemical compositions of the five Frit 503/SB4 glasses are to be determined by SRNL's Process Science Analytical Laboratory (PSAL). This memorandum provides an analytical plan to direct and support these measurements at PSAL. 
WSRC-STI-2006-00009

Revision 0

Appendix A (SRNL-SCS-2006-00014)

\subsection{INTRODUCTION}

Frit development efforts are underway at the Savannah River National Laboratory (SRNL) to support the processing of Sludge Batch 4 (SB4) at the Defense Waste Processing Facility (DWPF). One of the candidate frits considered during the recent assessments [1] of the baseline preparation plan (Case 15C) was Frit 503, which was called Frit 418-m10 in [1]. To provide experimental results to support the evaluation of this frit with SB4, five glasses have been fabricated for durability testing. Testing the durability of these glasses will also complement SRNL's ongoing nepheline studies by providing additional insight into the ability of the nepheline discriminator [2] to predict the occurrence of a nepheline primary crystalline phase for SB4 glasses and into the impact of nepheline on the durability of the SB4 glasses. In addition, the results from the study of these glasses will contribute needed data to the ComPro $^{\mathrm{TM}}$ database [3] in anticipation of a variability study for SB4.

The chemical compositions of the five Frit 503/SB4 glasses are to be determined by SRNL's Process Science Analytical Laboratory (PSAL). This memorandum provides an analytical plan to direct and support these measurements at PSAL.

\subsection{Analytical Plan}

The analytical procedures used by PSAL to determine cation concentrations for a glass sample include steps for sample preparation and for instrument calibration. Each glass is to be prepared in duplicate by each of two dissolution methods: lithium metaborate fusion (LM) and sodium peroxide fusion (PF).

The primary measurements of interest are to be acquired as follows. The samples prepared by LM are to be measured for barium $(\mathrm{Ba})$, calcium $(\mathrm{Ca})$, cerium $(\mathrm{Ce})$, chromium $(\mathrm{Cr})$, copper $(\mathrm{Cu})$, potassium $(\mathrm{K})$, lanthanum ( $\mathrm{La})$, magnesium $(\mathrm{Mg})$, manganese $(\mathrm{Mn})$, sodium $(\mathrm{Na})$, lead $(\mathrm{Pb})$, sulfur $(\mathrm{S})$, thorium $(\mathrm{Th})$, titanium (Ti), zinc $(\mathrm{Zn})$, and zirconium ( $\mathrm{Zr}$ ) concentrations. Samples prepared by PF are to be measured for aluminum (Al), boron (B), iron (Fe), lithium (Li), nickel (Ni), silicon ( $\mathrm{Si}$ ), and uranium (U). Samples dissolved by both preparation methods are to be measured using Inductively Coupled Plasma - Atomic Emission Spectrometry (ICP-AES). It should be noted that some of these elements are minor components that may be near detection limits for most, if not all, of the study glasses.

Randomizing the preparation steps and blocking and randomizing the measurements for the ICP-AES are of primary concern in the development of this analytical plan. The sources of uncertainty for the analytical procedure used by PSAL to determine the cation concentrations for the submitted glass samples are dominated by the dissolution step in the preparation of the sample and by the calibrations of the ICPAES. Samples of glass standards will be included in the analytical plan to provide an opportunity for checking the performance of the instrumentation over the course of the analyses and for potential biascorrection. Specifically, several samples of Waste Compliance Plan (WCP) Batch 1 (BCH) [4] and a uranium standard glass (Ustd) are included in this analytical plan. The reference compositions of these glasses are provided in Table 1. 
WSRC-STI-2006-00009

Revision 0

Appendix A (SRNL-SCS-2006-00014)

Table 1: Oxide Compositions of WCP Batch 1 (BCH) and of Ustd (wt \%)

\begin{tabular}{|c|c|c||}
\hline $\begin{array}{c}\text { Oxide/ } \\
\text { Anion }\end{array}$ & $\begin{array}{c}\text { BCH } \\
\text { (wt \%) }\end{array}$ & $\begin{array}{c}\text { Ustd } \\
\text { (wt \%) }\end{array}$ \\
\hline $\mathrm{Al}_{2} \mathrm{O}_{3}$ & 4.877 & 4.1 \\
\hline $\mathrm{B}_{2} \mathrm{O}_{3}$ & 7.777 & 9.209 \\
\hline $\mathrm{BaO}$ & 0.151 & 0 \\
\hline $\mathrm{CaO}$ & 1.22 & 1.301 \\
\hline $\mathrm{Cr}_{2} \mathrm{O}_{3}$ & 0.107 & 0 \\
\hline $\mathrm{Cs}_{2} \mathrm{O}$ & 0.06 & 0 \\
\hline $\mathrm{CuO}$ & 0.399 & 0 \\
\hline $\mathrm{Fe}_{2} \mathrm{O}_{3}$ & 12.839 & 13.196 \\
\hline $\mathrm{K}_{2} \mathrm{O}$ & 3.327 & 2.999 \\
\hline $\mathrm{Li}_{2} \mathrm{O}$ & 4.429 & 3.057 \\
\hline $\mathrm{MgO}$ & 1.419 & 1.21 \\
\hline $\mathrm{MnO}_{\mathrm{Na} O}$ & 1.726 & 2.892 \\
\hline $\mathrm{Nd}_{2} \mathrm{O}_{3}$ & 9.003 & 11.795 \\
\hline $\mathrm{NiO}_{\mathrm{RuO}}$ & 0.147 & 0 \\
\hline $\mathrm{SiO}_{2}$ & 0.751 & 1.12 \\
\hline $\mathrm{SO}_{3}$ & 0.0214 & 0 \\
\hline $\mathrm{TiO}_{2}$ & 50.22 & 45.353 \\
\hline $\mathrm{U}_{3} \mathrm{O}_{8}$ & 0 & 0 \\
\hline $\mathrm{ZrO}_{2}$ & 0.677 & 1.049 \\
\hline & 0 & 2.406 \\
\hline
\end{tabular}

Each glass sample submitted to PSAL will be prepared in duplicate by the LM and PF dissolution methods. Every prepared sample will be read twice by ICP-AES, with the instrument being calibrated before each of these two sets of readings. This will lead to four measurements for each cation of interest for each submitted glass.

Table 2 presents identifying codes, I01 through I05, for the 5 glasses fabricated for this study. The table provides a naming convention that is to be used in analyzing the glasses and reporting the measurements of their compositions. ${ }^{4}$

4 Renaming these samples helps to ensure that they will be processed as blind samples within PSAL. Table 2 is not shown in its entirety in the copies going to PSAL. 
WSRC-STI-2006-00009

Revision 0

Appendix A (SRNL-SCS-2006-00014)

Table 2: Glass Identifiers to Establish Blind Samples for PSAL

\begin{tabular}{|c|c||}
\hline $\begin{array}{c}\text { Glass } \\
\text { ID }\end{array}$ & $\begin{array}{c}\text { Sample } \\
\text { ID }\end{array}$ \\
\hline NEPHB-01 & I03 \\
\hline NEPHB-02 & I01 \\
\hline NEPHB-03 & I05 \\
\hline NEPHB-04 & I02 \\
\hline NEPHB-05 & I04 \\
\hline
\end{tabular}

\subsection{PREPARATION OF THE SAMPLES}

Each of the 5 glasses included in this analytical plan is to be prepared in duplicate by the LM and PF dissolution methods. Thus, the total number of prepared glass samples is determined by $5 \cdot 2 \cdot 2=20$, not including the samples of the $\mathrm{BCH}$ and Ustd glass standards that are to be prepared.

Table 3 provides blocking and (random) sequencing schema for conducting the preparation steps of the analytical procedures. One block of preparation work is provided for each preparation method to facilitate the scheduling of activities by work shift. The identifier for each of the prepared samples indicates the sample identifier (ID), preparation method, and duplicate number.

Table 3: Preparation Blocks by Dissolution Method

\begin{tabular}{|c|c|}
\hline LM (Lithium Metaborate) & PF (Peroxide Fusion) \\
\hline I03LM1 & I04PF1 \\
\hline I01LM1 & I02PF1 \\
\hline I03LM2 & I05PF1 \\
\hline I05LM1 & I01PF1 \\
\hline I04LM1 & I04PF2 \\
\hline I02LM1 & I03PF1 \\
\hline I05LM2 & I01PF2 \\
\hline I04LM2 & I05PF2 \\
\hline I02LM2 & I02PF2 \\
\hline I01LM2 & I03PF2 \\
\hline
\end{tabular}

\subsection{ICP-AES Calibration Blocks}

The glass samples prepared by the LM and PF dissolution methods are to be analyzed using ICP-AES instrumentation calibrated for the particular preparation method. After the initial set of cation concentration measurements, the ICP-AES instrumentation is to be recalibrated and a second set of concentration measurements for the cations determined.

Randomized plans for measuring cation concentrations in the LM-prepared and PF-prepared samples are provided in Table 4. The cations to be measured are specified as part of the table. In the tables, the sample identifiers for the 5 study glasses have been modified by the addition of a suffix (a "1"or a "2") to indicate whether the measurement was made during the first or second (respectively) calibration of the ICP-AES instrumentation. The identifiers for the $\mathrm{BCH}$ and Ustd samples have been modified to indicate 
WSRC-STI-2006-00009

the ICP-AES calibration and that each of these prepared samples is to be read 2 times (mirrored in the corresponding suffix of 1.2 , or 3 ) per calibration block.

Table 4: ICP-AES Blocks \& Calibration Groups by Preparation Method

\begin{tabular}{|c|c|c|c|}
\hline \multicolumn{2}{|c|}{ LM Glass Samples } & \multicolumn{2}{|c|}{ PF Glass Samples } \\
\hline \multicolumn{2}{|c|}{$\begin{array}{l}\text { Used to Measure Elemental } \mathrm{Ba}, \mathrm{Ca}, \mathrm{Ce}, \mathrm{Cr}, \mathrm{Cu}, \mathrm{K}, \mathrm{La} \text {, } \\
\qquad \mathrm{Mg}, \mathrm{Mn}, \mathrm{Na}, \mathrm{Pb}, \mathrm{S}, \mathrm{Th}, \mathrm{Ti}, \mathrm{Zn}, \& \mathrm{Zr}\end{array}$} & \multicolumn{2}{|c|}{ Used to Measure Elemental Al, B, Fe, Li, Ni, Si, \& U } \\
\hline \multicolumn{2}{|c|}{\begin{tabular}{|c|} 
LM Block \\
\end{tabular}} & \multicolumn{2}{|c|}{\begin{tabular}{|c|} 
PF Block \\
\end{tabular}} \\
\hline Calibration 1 & Calibration 2 & Calibration 1 & Calibration 2 \\
\hline BCHLM11 & BCHLM21 & BCHPF11 & BCHPF21 \\
\hline UstdLM11 & UstdLM21 & UstdPF11 & UstdPF21 \\
\hline I02LM11 & I01LM22 & I04PF21 & I05PF22 \\
\hline I04LM21 & I02LM22 & I03PF11 & I01PF22 \\
\hline I02LM21 & I03LM12 & I05PF11 & I02PF12 \\
\hline I01LM11 & I05LM12 & I03PF21 & I05PF12 \\
\hline I05LM21 & I03LM22 & I01PF21 & I04PF22 \\
\hline BCHLM12 & BCHLM22 & BCHPF12 & BCHPF22 \\
\hline UstdLM12 & UstdLM22 & UstdPF12 & UstdPF22 \\
\hline I04LM11 & I02LM12 & I02PF21 & I03PF22 \\
\hline I05LM11 & I01LM12 & I02PF11 & I04PF12 \\
\hline I03LM21 & I04LM22 & I01PF11 & I02PF22 \\
\hline I03LM11 & I04LM12 & I04PF11 & I03PF12 \\
\hline I01LM21 & I05LM22 & I05PF21 & I01PF12 \\
\hline BCHLM13 & BCHLM23 & BCHPF13 & BCHPF23 \\
\hline UstdLM13 & UstdLM23 & UstdPF13 & UstdPF23 \\
\hline
\end{tabular}

\subsection{Concluding Comments}

In summary, this analytical plan identifies two preparation blocks in Table 3 and four ICP-AES calibration blocks in Table 4 for use by PSAL. The sequencing of the activities associated with each of the steps in the analytical procedures has been randomized. The size of each of the blocks was selected so that it could be completed in a single work shift.

If a problem is discovered while measuring samples in a calibration block, the instrument should be recalibrated and the block of samples re-measured in its entirety. If for some reason the measurements are not conducted in the sequences presented in this report, a record should be made of the actual order used along with any explanative comments.

The analytical plan indicated in the preceding tables should be modified by the personnel of PSAL to include any calibration check standards and/or other standards that are part of their routine operating procedures. It is also recommended that the solutions resulting from each of the prepared samples be archived for some period, considering the "shelf-life" of the solutions, in case questions arise during data analysis. This would allow for the solutions to be rerun without additional preparations, thus minimizing cost. 


\subsection{REFERENCES}

[1] Peeler, D.K. and T.B. Edwards, "Model Based Assessments for the Baseline Sludge Batch 4 (Case 15C) Preparation Plan,” WSRC-TR-2006-00049, Revision 0, 2006.

[2] Li, H., P. Hrma, J.D. Vienna, M. Qian, Y. Su, and D.E. Smith, "Effects of $\mathrm{Al}_{2} \mathrm{O}_{3}, \mathrm{~B}_{2} \mathrm{O}_{3}, \mathrm{Na}_{2} \mathrm{O}$, and $\mathrm{SiO}_{2}$ on Nepheline Formation in Borosilicate Glasses: Chemical and Physical Correlations," Journal of Non-Crystalline Solids, 331, pgs. 202-216, 2003.

[3] Taylor, A.S., T.B. Edwards, J.C. George, T.K. Snyder, and D.K. Peeler, "The SRNL Glass Composition - Properties (ComPro) Database,” WSRC-RP-2004-00704, Revision 0, 2004.

[4] Jantzen, C.M., J.B. Pickett, K.G. Brown, T.B. Edwards, and D.C. Beam, "Process/ Product Models for the Defense Waste Processing Facility (DWPF): Part I. Predicting Glass Durability from Composition Using a Thermodynamic Hydration Energy Reaction Model (THERMO ${ }^{\mathrm{TM}}$ ) (U)," WSRC-TR-93-673, Revision 1, Volume 2, Table B.1, pp. B.9, 1995. 
WSRC-STI-2006-00009

Revision 0

Appendix B (SRNL-SCS-2006-00012)

This page intentionally left blank. 
Appendix B

\section{An Analytical Plan for Measuring PCT Solutions for a Set of Five Frit 503/SB4 Glasses (U)}

(SRNL-SCS-2006-00012) 
WSRC-STI-2006-00009

Revision 0

Appendix B (SRNL-SCS-2006-00012)

This page intentionally left blank. 
March 31, 2006

To: K. M. Fox, SRNL

\begin{tabular}{|c|c|c|}
\hline cc: & R. A. Baker, 773-42A & I. A. Reamer, 999-1W \\
\hline & D. R. Best, 786-1A (wo) & P. A. Toole, 786-1A (wo) \\
\hline & C. C. Herman, 999-W & R. C. Tuckfield, 773-42A \\
\hline & D. K. Peeler, 999-W & R. J. Workman, 999-1W \\
\hline
\end{tabular}

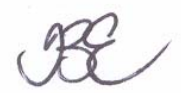

From: T. B. Edwards, 773-42A (5-5148)

Statistical Consulting Section

wo - without glass identifiers

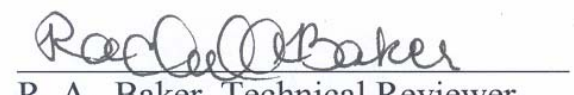

R. A. Baker, Technical Reviewer

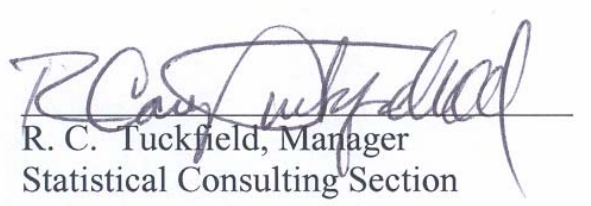

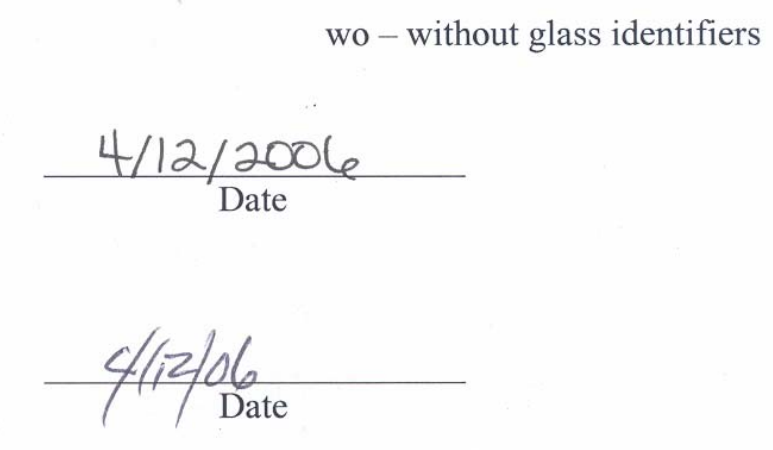

\section{An ANAl yTical Plan for MEASURING PCT SOLUTIONS FOR A SET OF FIVE FRIT 503/SB4 GLASSES (U)}


WSRC-STI-2006-00009

Revision 0

Appendix B (SRNL-SCS-2006-00012)

\subsection{EXECUTIVE SUMMARY}

Frit development efforts are underway at the Savannah River National Laboratory (SRNL) to support the processing of Sludge Batch 4 (SB4) at the Defense Waste Processing Facility (DWPF). One of the candidate frits considered during the recent assessments of the baseline preparation plan (Case 15C) was Frit 503, which was called Frit 418-m10 in the assessment. To provide experimental results to support the evaluation of this frit with SB4, five glasses have been fabricated for durability testing. Testing the durability of these glasses will also complement SRNL's ongoing nepheline studies by providing additional insight into the ability of the nepheline discriminator to predict the occurrence of a nepheline primary crystalline phase for SB4 glasses and into the impact of nepheline on the durability of the SB4 glasses.

The durability of the glasses is to be measured using the Product Consistency Test (PCT) as defined in ASTM C-1285-2002. Two heat treatments were utilized during the fabrication of each of these glasses. Specifically, each of the 5 glasses was quenched (i.e., rapidly cooled) and cooled in accordance with the centerline-canister-cooling (ccc) regime. Both heat treatments of each glass are to be subjected to the PCT.

The PCTs are to be submitted to SRNL's Process Science Analytical Laboratory (PSAL) for measurement. This memorandum provides an analytical plan for the measurement of the PCTs by PSAL. 
WSRC-STI-2006-00009

Revision 0

Appendix B (SRNL-SCS-2006-00012)

\subsection{INTRODUCTION}

Frit development efforts are underway at the Savannah River National Laboratory (SRNL) to support the processing of Sludge Batch 4 (SB4) at the Defense Waste Processing Facility (DWPF). One of the candidate frits considered during the recent assessments [1] of the baseline preparation plan (Case 15C) was Frit 503, which was called Frit 418-m10 in [1]. The specific SB4 option being considered is Case $15 \mathrm{C}$ Blend 1 as defined by Shah [2]. To provide experimental results to support the evaluation of this frit with SB4, five glasses have been fabricated for durability testing. Testing the durability of these glasses will also complement SRNL's ongoing nepheline studies by providing additional insight into the ability of the nepheline discriminator [3] to predict the occurrence of a nepheline primary crystalline phase for SB4 glasses and into the impact of nepheline on the durability of the SB4 glasses. In addition, the results from the study of these glasses will contribute needed data to the ComPro ${ }^{\mathrm{TM}}$ database [4] in anticipation of a variability study for SB4.

The durability of the glasses is to be measured using the Product Consistency Test (PCT) as defined in ASTM C-1285-2002 [5]. Two heat treatments were utilized during the fabrication of each of these glasses. Specifically, each of the 5 glasses was quenched (i.e., rapidly cooled) and cooled in accordance with the centerline-canister-cooling ( $\mathrm{ccc}$ ) regime. Both heat treatments of each glass are to be subjected to the PCT.

The PCTs are to be submitted to SRNL's Process Science Analytical Laboratory (PSAL) for measurement. This memorandum provides an analytical plan for the measurement of the PCTs by PSAL. Table 1 presents a listing of the glasses covered by this memorandum.

Table 1: Identifiers for Glasses Covered by this Plan

\begin{tabular}{|c|}
\hline NEPHB-01 \\
\hline NEPHB-01ccc \\
\hline NEPHB-02 \\
\hline NEPHB-02ccc \\
\hline NEPHB-03 \\
\hline NEPHB-03ccc \\
\hline NEPHB-04 \\
\hline NEPHB-04ccc \\
\hline NEPHB-05 \\
\hline NEPHB-05ccc \\
\hline
\end{tabular}

\subsection{Discussion}

Each of the study glasses of Table 1 is to be subjected to the PCT in triplicate. In addition to PCTs for the study glasses, triplicate PCTs are to be conducted on a sample of the Approved Reference Material - One (ARM-1) glass and a sample of the Environmental Assessment (EA) glass. Two reagent blank samples are also to be included in these tests. This results in 38 sample solutions being required to complete these PCTs.

The leachates from these tests will be diluted by adding $4 \mathrm{~mL}$ of $0.4 \mathrm{M} \mathrm{HNO}_{3}$ to $6 \mathrm{~mL}$ of the leachate (a 6:10 volume to volume, v:v, dilution) before being submitted to PSAL. The leachates of EA will be 
further diluted $(1: 10 \mathrm{v}: \mathrm{v})$ with deionized water prior to submission to PSAL in order to prevent problems with the nebulizer. Note that additional dilutions for the ccc versions of one or more of the study glasses may be needed due to a possible low durability of some of the glasses. Upon termination of the PCT, a decision is to be made (by the technicians and a PSAL representative, if called by the technician) as to whether any other dilution is needed for these solutions to mitigate any potential gelling issues. Any extra dilutions are to be reported, and guidance is to be given as to how the dilutions are to be handled in the statistical assessment of the measurement data. More specifically, PSAL will be responsible for indicating if any additional dilutions were made and how they were, or how they should be, accounted for in the reported measurements.

Table 2 presents identifying codes, J01 through J38, for the individual solutions required for the PCTs of the select study glasses and of the standards (EA, ARM-1, and blanks). This provides a naming convention that is to be used by PSAL in analyzing the solutions and reporting the relevant concentration measurements. $^{\text {a }}$

Table 2: Identifiers for the PCT Solutions Covered by this Plan

\begin{tabular}{|c|c|c|c|}
\hline $\begin{array}{c}\text { Original } \\
\text { Sample } \\
\text { NEPHB-01 }\end{array}$ & $\begin{array}{c}\text { Solution } \\
\text { Identifier }\end{array}$ & $\begin{array}{c}\text { Original } \\
\text { Sample }\end{array}$ & $\begin{array}{c}\text { Solution } \\
\text { Identifier }\end{array}$ \\
\hline NEPHB-01 & J24 & NEPHB-04ccc & J37 \\
\hline NEPHB-01 & J05 & NEPHB-04ccc & J08 \\
\hline NEPHB-01ccc & J26 & NEPHB-04ccc & J09 \\
\hline NEPHB-01ccc & J36 & NEPHB-05 & J10 \\
\hline NEPHB-01ccc & J17 & NEPHB-05 & J20 \\
\hline NEPHB-02 & J30 & NEPHB-05ccc & J12 \\
\hline NEPHB-02 & J32 & NEPHB-05ccc & J06 \\
\hline NEPHB-02 & J07 & NEPHB-05ccc & J27 \\
\hline NEPHB-02ccc & J04 & EA & J16 \\
\hline NEPHB-02ccc & J13 & EA & J31 \\
\hline NEPHB-02ccc & J22 & EA & J23 \\
\hline NEPHB-03 & J28 & ARM-1 & J15 \\
\hline NEPHB-03 & J35 & ARM-1 & J14 \\
\hline NEPHB-03 & J01 & ARM-1 & J19 \\
\hline NEPHB-03ccc & J29 & blank & J02 \\
\hline NEPHB-03ccc & J11 & blank & J21 \\
\hline NEPHB-03ccc & J03 & & \\
\hline NEPHB-04 & J34 & & \\
\hline NEPHB-04 & J38 & & \\
\hline NEPHB-04 & J33 & & \\
\hline
\end{tabular}

a Renaming these samples ensures that they will be processed as blind samples by PSAL. This table does not contain the solution identifiers for those on the distribution list with a "wo" following their names. 
WSRC-STI-2006-00009

Revision 0

Appendix B (SRNL-SCS-2006-00012)

\subsection{Analytical Plan}

The analytical plan for PSAL is provided in this section. Each of the solution samples submitted to PSAL is to be analyzed only once for each of the following: boron $(\mathrm{B})$, barium $(\mathrm{Ba})$, cadmium $(\mathrm{Cd})$, chromium $(\mathrm{Cr})$, iron $(\mathrm{Fe})$, lithium $(\mathrm{Li})$, sodium $(\mathrm{Na})$, lead $(\mathrm{Pb})$, silicon $(\mathrm{Si})$, thorium $(\mathrm{Th})$, and uranium $(\mathrm{U})$. B, Li, $\mathrm{Na}$, and $\mathrm{Si}$ are the elements that are to be used in the assessment of glass durability; the other elements are being monitored to address solution disposal issues in SRNL upon termination of the PCTs. The measurements are to be made in parts per million ( $\mathrm{ppm}$ ). The analytical procedure used by PSAL to determine the concentrations utilizes an Inductively Coupled Plasma - Atomic Emission Spectrometer (ICP-AES). The PCT solutions (as identified in Table 2) are grouped in three ICP-AES blocks for processing by PSAL in Table 3. Each block requires a different calibration of the ICP-AES.

Table 3: ICP-AES Calibration Blocks for Leachate Measurements

\begin{tabular}{|c|c|c|}
\hline Block 1 & Block 2 & Block 3 \\
\hline std-b1-1 & std-b2-1 & std-b3-1 \\
\hline J02 & J11 & J17 \\
\hline J15 & J36 & J22 \\
\hline J34 & J31 & J20 \\
\hline J37 & J06 & J07 \\
\hline J25 & J14 & J19 \\
\hline J28 & J35 & J27 \\
\hline J26 & J32 & J03 \\
\hline std-b1-2 & std-b2-2 & std-b3-2 \\
\hline J16 & J10 & J33 \\
\hline J29 & J08 & J21 \\
\hline J04 & J38 & J09 \\
\hline J24 & J13 & J23 \\
\hline J30 & J05 & J18 \\
\hline J12 & std-b2-3 & J01 \\
\hline std-b1-3 & & std-b3-3 \\
\hline
\end{tabular}

A multi-element solution standard (denoted by "std-bi-j" where $i=1$ to 3 represents the block number and $\mathrm{j}=1,2$, and 3 represents the position in the block) was added at the beginning, middle, and end of each of the three blocks. This standard may be useful in checking and correcting for bias in the concentration measurements arising from the ICP calibrations.

\subsection{SUMMARY}

In summary, this analytical plan provides identifiers for the PCT solutions in Table 2 and three ICP-AES calibration blocks in Table 3 for PSAL to use in conducting the boron (B), barium (Ba), cadmium (Cd), chromium $(\mathrm{Cr})$, iron $(\mathrm{Fe})$, lithium $(\mathrm{Li})$, sodium $(\mathrm{Na})$, lead $(\mathrm{Pb})$, silicon $(\mathrm{Si})$, thorium $(\mathrm{Th})$, and uranium (U) concentration measurements for the PCT study of this select subset of glasses for SB4. The sequencing of the activities associated with each of the steps in the analytical procedure has been randomized. The size of the blocks was selected so that each block could be completed in a single work shift. If for some reason the measurements are not conducted in the sequence presented in this memorandum, the actual order should be recorded along with any explanative comments. 
The analytical plan indicated in the preceding tables should be modified by the personnel of PSAL to include any calibration check standards and/or other standards that are part of their standard operating procedures.

\subsection{REFERENCES}

[1] Peeler, D.K. and T.B. Edwards, "Model Based Assessments for the Baseline Sludge Batch 4 (Case 15C) Preparation Plan,” WSRC-TR-2006-00049, Revision 0, 2006.

[2] Shah, H.B., "Estimate of Sludge Batch 4 Calcine Composition Additional Cases for Final Recommendation," CBU-PIT-2006-00011, Revision 0, 2006.

[3] Li, H., P. Hrma, J.D. Vienna, M. Qian, Y. Su, and D.E. Smith, "Effects of $\mathrm{Al}_{2} \mathrm{O}_{3}, \mathrm{~B}_{2} \mathrm{O}_{3}, \mathrm{Na}_{2} \mathrm{O}$, and $\mathrm{SiO}_{2}$ on Nepheline Formation in Borosilicate Glasses: Chemical and Physical Correlations," Journal of Non-Crystalline Solids, 331, pgs. 202-216, 2003.

[4] Taylor, A.S., T.B. Edwards, J.C. George, T.K. Snyder, and D.K. Peeler, "The SRNL Glass Composition - Properties (ComPro) Database,” WSRC-RP-2004-00704, Revision 0, 2004.

[5] ASTM C-1285-2002, "Standard Test Methods for Determining Chemical Durability of Nuclear Waste Glasses: The Product Consistency Test (PCT)," ASTM, 2002. 


\section{Appendix C}

\section{An Analytical Plan for Measuring a Second Set of PCT Solutions for the Five CCC Frit 503/SB4 Glasses (U)}

(SRNL-SCS-2006-00018) 
WSRC-STI-2006-00009

Revision 0

Appendix C (SRNL-SCS-2006-00018)

This page intentionally left blank. 


\section{SRNL-SCS-2006-00018}

May 19, 2006

To: $\quad$ K. M. Fox, SRNL

cc:
R. A. Baker, 773-42A
D. R. Best, 786-1A (wo)
C. C. Herman, 999-W
D. K. Peeler, 999-W

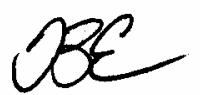

From: T. B. Edwards, 773-42A (5-5148)

Statistical Consulting Section
I. A. Reamer, 999-1W

P. A. Toole, 786-1A (wo)

R. C. Tuckfield, 773-42A

R. J. Workman, 999-1W

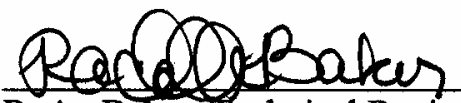

R. A. Baker, Technical Reviewer

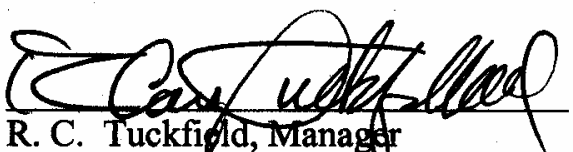

R. C. Tuckfigd wo - without glass identifiers

\section{An Analytical Plan for Measuring a SECOND SET OF PCT SOLUTIONS FOR THE FIVE CCC FRIT 503/SB4 GLASSES (U)}


WSRC-STI-2006-00009

Revision 0

Appendix C (SRNL-SCS-2006-00018)

\subsection{EXECUTIVE SUMMARY}

Frit development efforts are underway at the Savannah River National Laboratory (SRNL) to support the processing of Sludge Batch 4 (SB4) at the Defense Waste Processing Facility (DWPF). One of the candidate frits considered during the recent assessments of the baseline preparation plan (Case 15C) was Frit 503, which was called Frit 418-m10 in the assessment. To provide experimental results to support the evaluation of this frit with SB4, five glasses were fabricated for durability testing. Testing the durability of these glasses will also complement SRNL's ongoing nepheline studies by providing additional insight into the ability of the nepheline discriminator to predict the occurrence of a nepheline primary crystalline phase for SB4 glasses and into the impact of nepheline on the durability of the SB4 glasses.

The durability of the glasses was measured using the Product Consistency Test (PCT) as defined in ASTM C-1285-2002. Two heat treatments were utilized during the fabrication of each of these glasses. Specifically, each of the 5 glasses was quenched (i.e., rapidly cooled) and cooled in accordance with the centerline-canister-cooling (ccc) regime. Both heat treatments of each glass were subjected to the PCT. The interpretation of the ccc results was somewhat unclear; so a decision was made to repeat the ccc tests.

The PCTs for the cce glasses are to be submitted to SRNL's Process Science Analytical Laboratory (PSAL) for measurement. This memorandum provides an analytical plan for the measurement of the PCTs by PSAL. 
WSRC-STI-2006-00009

Revision 0

Appendix C (SRNL-SCS-2006-00018)

\subsection{INTRODUCTION}

Frit development efforts are underway at the Savannah River National Laboratory (SRNL) to support the processing of Sludge Batch 4 (SB4) at the Defense Waste Processing Facility (DWPF). One of the candidate frits considered during the recent assessments [1] of the baseline preparation plan (Case 15C) was Frit 503, which was called Frit 418-m10 in [1]. The specific SB4 option being considered is Case $15 \mathrm{C}$ Blend 1 as defined by Shah [2]. To provide experimental results to support the evaluation of this frit with SB4, five glasses were fabricated for durability testing. Testing the durability of these glasses will also complement SRNL's ongoing nepheline studies by providing additional insight into the ability of the nepheline discriminator [3] to predict the occurrence of a nepheline primary crystalline phase for SB4 glasses and into the impact of nepheline on the durability of the SB4 glasses. In addition, the results from the study of these glasses will contribute needed data to the ComPro ${ }^{\mathrm{TM}}$ database [4] in anticipation of a variability study for SB4.

The durability of the glasses was measured using the Product Consistency Test (PCT) as defined in ASTM C-1285-2002 [5]. Two heat treatments were utilized during the fabrication of each of these glasses. Specifically, each of the 5 glasses was quenched (i.e., rapidly cooled) and cooled in accordance with the centerline-canister-cooling ( $\mathrm{ccc}$ ) regime. Both heat treatments of each glass were subjected to the PCT. The PCT solutions were analyzed under the auspices of the pertinent analytical plan [6], but the interpretation of the ccc results was somewhat unclear; so a decision was made to repeat the ccc tests. Specifically, the PCT response for NEPHB-04ccc and NEPHB-05ccc appeared to be inconsistent with previous trends with respect to the impact of waste loading on durability. Although the data would not have an impact on the conclusions drawn, the data did imply that the glasses may have been inadvertently switched during the durability assessment. To address this issue, the PCT responses for all five "NEPHB" ccc glasses are being reevaluated.

The PCTs for the ccc glasses are to be submitted to SRNL's Process Science Analytical Laboratory (PSAL) for measurement. This memorandum provides an analytical plan for the measurement of the PCTs by PSAL. Table 1 presents a listing of the glasses covered by this memorandum.

Table 1: Identifiers for Glasses Covered by this Plan

\begin{tabular}{|l|}
\hline NEPHB-01ccc \\
\hline NEPHB-02ccc \\
\hline NEPHB-03ccc \\
\hline NEPHB-04ccc \\
\hline NEPHB-05ccc \\
\hline
\end{tabular}

\subsection{Discussion}

Each of the study glasses of Table 1 is to be subjected to the PCT in triplicate. In addition to PCTs for the study glasses, triplicate PCTs are to be conducted on a sample of the Approved Reference Material - One (ARM-1) glass and a sample of the Environmental Assessment (EA) glass. Two reagent blank samples are also to be included in these tests. This results in 23 sample solutions being required to complete these PCTs. 
The leachates from these tests will be diluted by adding $4 \mathrm{~mL}$ of $0.4 \mathrm{M} \mathrm{HNO}_{3}$ to $6 \mathrm{~mL}$ of the leachate (a 6:10 volume to volume, $\mathrm{v}: \mathrm{v}$, dilution) before being submitted to PSAL. The leachates of EA will be further diluted $(1: 10 \mathrm{v}: \mathrm{v})$ with deionized water prior to submission to PSAL in order to prevent problems with the nebulizer. Note that additional dilutions for the ccc versions of one or more of the study glasses may be needed due to a possible low durability of some of the glasses. Upon termination of the PCT, a decision is to be made (by the technicians and a PSAL representative, if called by the technician) as to whether any other dilutions are needed for these solutions to mitigate any potential gelling issues. Any extra dilutions are to be reported, and guidance is to be given as to how the dilutions are to be handled in the statistical assessment of the measurement data. More specifically, PSAL will be responsible for indicating if any additional dilutions were made and how they were, or how they should be, accounted for in the reported measurements.

Table 2 presents identifying codes, K01 through K23, for the individual solutions required for the PCTs of the select study glasses and of the standards (EA, ARM-1, and blanks). This provides a naming convention that is to be used by PSAL in analyzing the solutions and reporting the relevant concentration measurements. ${ }^{6}$

Table 2: Identifiers for the PCT Solutions Covered by this Plan

\begin{tabular}{|c|c|c|c|}
\hline $\begin{array}{c}\text { Original } \\
\text { Sample }\end{array}$ & $\begin{array}{c}\text { Solution } \\
\text { Identifier }\end{array}$ & $\begin{array}{c}\text { Original } \\
\text { Sample }\end{array}$ & $\begin{array}{c}\text { Solution } \\
\text { Identifier }\end{array}$ \\
\hline NEPHB-01ccc & K17 & EA & K05 \\
\hline NEPHB-01ccc & K01 & EA & K15 \\
\hline NEPHB-01ccc & K14 & EA & K20 \\
\hline NEPHB-02ccc & K22 & ARM-1 & K18 \\
\hline NEPHB-02ccc & K06 & ARM-1 & K02 \\
\hline NEPHB-02ccc & K10 & ARM-1 & K04 \\
\hline NEPHB-03ccc & K23 & blank & K08 \\
\hline NEPHB-03ccc & K16 & blank & K19 \\
\hline NEPHB-03ccc & K11 & & \\
\hline NEPHB-04ccc & K21 & & \\
\hline NEPHB-04ccc & K09 & & \\
\hline NEPHB-04ccc & K03 & & \\
\hline NEPHB-05ccc & K13 & & \\
\hline NEPHB-05ccc & K12 & & \\
\hline NEPHB-05ccc & K07 & & \\
\hline
\end{tabular}

\subsection{Analytical Plan}

The analytical plan for PSAL is provided in this section. Each of the solution samples submitted to PSAL is to be analyzed only once for each of the following: boron $(\mathrm{B})$, barium $(\mathrm{Ba})$, cadmium $(\mathrm{Cd})$, chromium $(\mathrm{Cr})$, iron $(\mathrm{Fe})$, lithium $(\mathrm{Li})$, sodium $(\mathrm{Na})$, lead $(\mathrm{Pb})$, silicon $(\mathrm{Si})$, thorium $(\mathrm{Th})$, and uranium $(\mathrm{U}) . \mathrm{B}, \mathrm{Li}$, $\mathrm{Na}$, and $\mathrm{Si}$ are the elements that are to be used in the assessment of glass durability; the other elements are being monitored to address solution disposal issues in SRNL upon termination of the PCTs. The

6 Renaming these samples ensures that they will be processed as blind samples by PSAL. This table does not contain the solution identifiers for those on the distribution list with a "wo" following their names. 
WSRC-STI-2006-00009

Appendix C (SRNL-SCS-2006-00018)

measurements are to be made in parts per million ( $\mathrm{ppm})$. The analytical procedure used by PSAL to determine the concentrations utilizes an Inductively Coupled Plasma - Atomic Emission Spectrometer (ICP-AES). The PCT solutions (as identified in Table 2) are grouped in three ICP-AES blocks for processing by PSAL in Table 3. Each block requires a different calibration of the ICP-AES.

Table 3: ICP-AES Calibration Blocks for Leachate Measurements

\begin{tabular}{|c|c|c|}
\hline Block 1 & Block 2 & Block 3 \\
\hline std-b1-1 & std-b2-1 & std-b3-1 \\
\hline K05 & K16 & K03 \\
\hline K17 & K02 & K10 \\
\hline K22 & K01 & K20 \\
\hline K18 & K06 & K11 \\
\hline std-b1-2 & std-b2-2 & std-b3-2 \\
\hline K08 & K09 & K04 \\
\hline K21 & K15 & K19 \\
\hline K23 & K12 & K07 \\
\hline K13 & std-b2-3 & K14 \\
\hline std-b1-3 & & std-b3-3 \\
\hline
\end{tabular}

A multi-element solution standard (denoted by "std-bi-j" where $i=1$ to 3 represents the block number and $\mathrm{j}=1,2$, and 3 represents the position in the block) was added at the beginning, middle, and end of each of the three blocks. This standard may be useful in checking and correcting for bias in the concentration measurements arising from the ICP calibrations.

\subsection{SUMMARY}

In summary, this analytical plan provides identifiers for the PCT solutions in Table 2 and three ICP-AES calibration blocks in Table 3 for PSAL to use in conducting the boron (B), barium (Ba), cadmium (Cd), chromium $(\mathrm{Cr})$, iron $(\mathrm{Fe})$, lithium $(\mathrm{Li})$, sodium $(\mathrm{Na})$, lead $(\mathrm{Pb})$, silicon $(\mathrm{Si})$, thorium $(\mathrm{Th})$, and uranium (U) concentration measurements for the PCT study of this select subset of glasses for SB4. The sequencing of the activities associated with each of the steps in the analytical procedure has been randomized. The size of the blocks was selected so that each block could be completed in a single work shift. If for some reason the measurements are not conducted in the sequence presented in this memorandum, the actual order should be recorded along with any explanative comments.

The analytical plan indicated in the preceding tables should be modified by the personnel of PSAL to include any calibration check standards and/or other standards that are part of their standard operating procedures.

\subsection{REFERENCES}

[1] Peeler, D.K. and T.B. Edwards, "Model Based Assessments for the Baseline Sludge Batch 4 (Case 15C) Preparation Plan,” WSRC-TR-2006-00049, Revision 0, 2006. 
[2] Shah, H.B., "Estimate of Sludge Batch 4 Calcine Composition Additional Cases for Final Recommendation," CBU-PIT-2006-00011, Revision 0, 2006.

[3] Li, H., P. Hrma, J.D. Vienna, M. Qian, Y. Su, and D.E. Smith, "Effects of $\mathrm{Al}_{2} \mathrm{O}_{3}, \mathrm{~B}_{2} \mathrm{O}_{3}, \mathrm{Na}_{2} \mathrm{O}$, and $\mathrm{SiO}_{2}$ on Nepheline Formation in Borosilicate Glasses: Chemical and Physical Correlations," Journal of Non-Crystalline Solids, 331, pgs. 202-216, 2003.

[4] Taylor, A.S., T.B. Edwards, J.C. George, T.K. Snyder, and D.K. Peeler, "The SRNL Glass Composition - Properties (ComPro ${ }^{\mathrm{TM}}$ ) Database," WSRC-RP-2004-00704, Revision 0, 2004.

[5] ASTM C-1285-2002, "Standard Test Methods for Determining Chemical Durability of Nuclear Waste Glasses: The Product Consistency Test (PCT)," ASTM, 2002.

[6] Edwards, T.B., "An Analytical Plan for Measuring PCT Solutions for a Set of Five Frit 503/SB4 Glasses," SRNL-SCS-2006-00012, March 31, 2006. 


\section{Appendix D}

\section{Tables and Exhibits Supporting the Analysis of the Chemical Composition Measurements of the Frit 503 - SB4 Study Glasses}


Table D1. Targeted Oxide Concentrations (as wt \%'s) for the Frit 503/SB4 Study Glasses

\begin{tabular}{|c|c|c|c|c|c|c|c|c|c|c|c|c|c|c|c|c|c|c|c|c|c|c|c|c|}
\hline Glass \# & Al2O3 & B2O3 & BaO & $\mathrm{CaO}$ & $\mathrm{Ce2O3}$ & Cr2O3 & $\mathrm{CuO}$ & Fe2O3 & K2O & La2O3 & Li2O & MgO & MnO & Na2O & $\mathrm{NiO}$ & PbO & SO4 & $\mathrm{SiO} 2$ & ThO2 & TiO2 & U308 & ZnO & ZrO2 & Sum \\
\hline NEPHB-01 & 7.4417 & 9.8000 & 0.0378 & 0.7162 & 0.0449 & 0.0636 & 0.0179 & 7.9697 & 0.1032 & 0.0325 & 5.6000 & 0.7486 & 1.6440 & 9.4239 & 0.4731 & 0.0271 & 0.4014 & 53.0340 & 0.0197 & 0.0080 & 2.2921 & 0.0293 & \begin{tabular}{|l|l|}
30.0711 \\
\end{tabular} & 100.000 \\
\hline NEPH & 6820 & 1000 & .0441 & 0.8356 & 0524 & 0742 & 0.0209 & 2979 & 1204 & 0379 & 5.2000 & 0.8734 & 1.9180 & 10.3279 & 0.5520 & 0.0317 & 0.4683 & 49.5396 & .0230 & 0.0093 & 2.6741 & 0.0342 & .0830 & 100.000 \\
\hline NEPHB-03 & 9.9223 & 8.4000 & 0.0504 & 0.9550 & 0.0599 & 0.0848 & 0.0239 & 10.6262 & 0.1376 & 0434 & 4.8000 & 0.9982 & 2.1920 & 11.2318 & 0.6308 & 0.0362 & 0.5352 & 46.0453 & 0.0263 & 0.0107 & 3.0561 & 0.0390 & .0948 & 00.000 \\
\hline NEPHB-04 & 11.1626 & 7.7000 & 0.0567 & 1.0743 & 0.0674 & 0.0954 & 0.0269 & 11.9545 & 0.1548 & 0.0488 & 4.4000 & 1.1229 & 2.4660 & 12.1358 & 0.7097 & 0.0407 & 0.6021 & 42.5509 & 0.0296 & 0.0120 & 3.4381 & 0.0439 & \begin{tabular}{|l|l|}
9 & 0.1067 \\
\end{tabular} & 100.000 \\
\hline NEPHB-05 & 12.4029 & 7.0000 & 0.0630 & 1.1937 & 0.0749 & 0.1061 & 0.0299 & 13.2827 & 0.1721 & 0.0542 & 4.0000 & 1.2477 & 2.7401 & 13.0398 & 0.7886 & 0.0452 & 0.6690 & 39.0566 & 0.0329 & 0.0133 & 3.8201 & 0.0488 & \begin{tabular}{l|l|}
8.1185 \\
\end{tabular} & 100.000 \\
\hline
\end{tabular}


Table D2. Measured Elemental Concentrations (wt\%) for Samples Prepared Using Lithium Metaborate

\begin{tabular}{|c|c|c|c|c|c|c|c|c|c|c|c|c|c|c|c|c|c|c|c|}
\hline Glass & Laboratory & & Analytical & & & & & & & & & & & & & & & & \\
\hline ID & ID & Block & Sequence & Ba & Ca & Ce & $\mathrm{Cr}$ & $\mathbf{C u}$ & $\mathbf{K}$ & La & Mg & Mn & $\mathrm{Na}$ & $\mathbf{P b}$ & $\mathrm{S}$ & Th & Ti & Zn & $\mathrm{Zr}$ \\
\hline Batch 1 & BCHLM11 & 1 & 1 & 0.127 & 0.816 & $<0.010$ & 0.067 & 0.294 & 2.44 & $<0.010$ & 0.816 & 1.36 & 6.91 & $<0.020$ & $<0.100$ & $<0.010$ & 0.393 & 0.035 & 0.066 \\
\hline Ustd & UstdLM11 & 1 & 2 & $<0.010$ & 0.852 & $<0.010$ & 0.154 & $<0.010$ & 2.33 & $<0.010$ & 0.672 & 2.29 & 9.20 & $<0.020$ & $<0.100$ & 0.048 & 0.551 & $<0.010$ & $<0.010$ \\
\hline NEPHB-04 & I02LM11 & 1 & 3 & 0.047 & 0.691 & 0.044 & 0.044 & 0.029 & 0.133 & 0.037 & 0.639 & 2.01 & 9.11 & 0.037 & 0.187 & 0.088 & $<0.010$ & 0.063 & 0.069 \\
\hline NEPHB-05 & I04LM21 & 1 & 4 & 0.054 & 0.771 & 0.057 & 0.048 & 0.029 & 0.148 & 0.041 & 0.712 & 2.20 & 9.65 & 0.044 & 0.197 & 0.103 & $<0.010$ & 0.047 & 0.082 \\
\hline NEPHB-04 & I02LM21 & 1 & 5 & 0.047 & 0.690 & 0.044 & 0.044 & 0.034 & 0.133 & 0.037 & 0.641 & 1.98 & 8.98 & 0.038 & 0.180 & 0.090 & $<0.010$ & 0.047 & 0.070 \\
\hline NEPHB-02 & I01LM11 & 1 & 6 & 0.037 & 0.545 & 0.038 & 0.037 & 0.021 & 0.099 & 0.028 & 0.500 & 1.52 & 7.69 & 0.031 & 0.144 & 0.071 & $<0.010$ & 0.032 & 0.046 \\
\hline NEPHB-03 & I05LM21 & 1 & 7 & 0.043 & 0.625 & 0.034 & 0.042 & 0.026 & 0.114 & 0.031 & 0.576 & 1.70 & 8.38 & 0.033 & 0.167 & 0.081 & $<0.010$ & 0.046 & 0.066 \\
\hline Batch 1 & BCHLM12 & 1 & 8 & 0.126 & 0.811 & $<0.010$ & 0.067 & 0.297 & 2.46 & $<0.010$ & 0.820 & 1.33 & 6.85 & $<0.020$ & $<0.100$ & $<0.010$ & 0.390 & 0.035 & 0.066 \\
\hline Ustd & UstdLM12 & 1 & 9 & $<0.010$ & 0.880 & $<0.010$ & 0.154 & $<0.010$ & 2.39 & $<0.010$ & 0.679 & 2.19 & 8.89 & $<0.020$ & $<0.100$ & 0.049 & 0.554 & $<0.010$ & $<0.010$ \\
\hline NEPHB-05 & I04LM11 & 1 & 10 & 0.055 & 0.778 & 0.056 & 0.049 & 0.030 & 0.144 & 0.041 & 0.713 & 2.22 & 9.84 & 0.044 & 0.197 & 0.103 & $<0.010$ & 0.045 & 0.083 \\
\hline NEPHB-03 & I05LM11 & 1 & 11 & 0.044 & 0.642 & 0.035 & 0.042 & 0.026 & 0.120 & 0.032 & 0.586 & 1.78 & 8.31 & 0.033 & 0.171 & 0.083 & $<0.010$ & 0.047 & 0.068 \\
\hline NEPHB-01 & I03LM21 & 1 & 12 & 0.033 & 0.483 & 0.027 & 0.025 & 0.020 & 0.083 & 0.023 & 0.436 & 1.39 & 7.11 & 0.036 & 0.128 & 0.063 & $<0.010$ & 0.027 & 0.041 \\
\hline NEPHB-01 & I03LM11 & 1 & 13 & 0.032 & 0.504 & 0.027 & 0.025 & 0.019 & 0.082 & 0.023 & 0.434 & 1.36 & 7.06 & 0.035 & 0.130 & 0.062 & $<0.010$ & 0.040 & 0.040 \\
\hline NEPHB-02 & I01LM21 & 1 & 14 & 0.037 & 0.555 & 0.039 & 0.037 & 0.022 & 0.104 & 0.028 & 0.498 & 1.59 & 7.40 & 0.031 & 0.147 & 0.071 & $<0.010$ & 0.032 & 0.047 \\
\hline Batch 1 & BCHLM13 & 1 & 15 & 0.127 & 0.837 & $<0.010$ & 0.067 & 0.300 & 2.48 & $<0.010$ & 0.818 & 1.42 & 6.84 & $<0.020$ & $<0.100$ & $<0.010$ & 0.394 & 0.035 & 0.067 \\
\hline Ustd & UstdLM13 & 1 & 16 & $<0.010$ & 0.871 & $<0.010$ & 0.154 & $<0.010$ & 2.38 & $<0.010$ & 0.670 & 2.29 & 9.07 & $<0.020$ & $<0.100$ & 0.049 & 0.550 & $<0.010$ & $<0.010$ \\
\hline Batch 1 & BCHLM21 & 2 & 1 & 0.127 & 0.824 & $<0.010$ & 0.066 & 0.297 & 2.45 & $<0.010$ & 0.821 & 1.38 & 7.13 & $<0.020$ & $<0.100$ & $<0.010$ & 0.392 & 0.034 & 0.066 \\
\hline Ustd & UstdLM21 & 2 & 2 & $<0.010$ & 0.883 & $<0.010$ & 0.154 & $<0.010$ & 2.37 & $<0.010$ & 0.682 & 2.27 & 9.47 & $<0.020$ & $<0.100$ & \begin{tabular}{|l|}
0.049 \\
\end{tabular} & 0.557 & $<0.010$ & $<0.010$ \\
\hline NEPHB-02 & I01LM22 & 2 & 3 & 0.037 & 0.546 & 0.039 & 0.036 & 0.021 & 0.101 & 0.028 & 0.506 & 1.49 & 7.76 & 0.030 & \begin{tabular}{|l|l|}
0.148 \\
\end{tabular} & 0.072 & $<0.010$ & 0.031 & \begin{tabular}{|l|}
0.046 \\
\end{tabular} \\
\hline NEPHB-04 & I02LM22 & 2 & 4 & 0.046 & 0.704 & 0.045 & 0.043 & 0.034 & 0.134 & 0.036 & 0.646 & 1.94 & 9.22 & 0.037 & 0.178 & 0.089 & $<0.010$ & 0.046 & 0.070 \\
\hline NEPHB-01 & I03LM12 & 2 & 5 & 0.032 & 0.508 & 0.027 & 0.024 & 0.018 & 0.080 & 0.023 & 0.435 & 1.32 & 7.25 & 0.033 & 0.125 & 0.062 & $<0.010$ & 0.039 & 0.040 \\
\hline NEPHB-03 & I05LM12 & 2 & 6 & 0.043 & 0.628 & 0.035 & 0.041 & 0.024 & 0.115 & 0.031 & 0.582 & 1.78 & 8.44 & 0.032 & 0.164 & 0.082 & $<0.010$ & 0.046 & 0.066 \\
\hline NEPHB-01 & I03LM22 & 2 & 7 & 0.032 & 0.481 & 0.027 & 0.024 & 0.019 & 0.080 & 0.023 & 0.439 & 1.34 & 7.33 & 0.034 & 0.126 & 0.062 & $<0.010$ & 0.026 & 0.040 \\
\hline Batch 1 & BCHLM22 & 2 & 8 & 0.127 & 0.815 & $<0.010$ & 0.066 & 0.296 & 2.47 & $<0.010$ & 0.824 & 1.39 & 7.03 & $<0.020$ & $<0.100$ & $<0.010$ & 0.390 & 0.033 & 0.066 \\
\hline Ustd & UstdLM22 & 2 & 9 & $<0.010$ & 0.876 & $<0.010$ & 0.153 & $<0.010$ & 2.36 & $<0.010$ & 0.678 & 2.25 & 9.05 & $<0.020$ & $<0.100$ & \begin{tabular}{|l|}
0.047 \\
\end{tabular} & 0.551 & $<0.010$ & $<0.010$ \\
\hline NEPHB-04 & I02LM12 & 2 & 10 & 0.046 & 0.699 & 0.044 & 0.043 & 0.028 & 0.132 & 0.036 & 0.642 & 1.98 & 9.47 & 0.036 & 0.179 & 0.087 & $<0.010$ & 0.062 & 0.069 \\
\hline NEPHB-02 & I01LM12 & 2 & 11 & 0.037 & 0.541 & 0.039 & 0.037 & 0.021 & 0.101 & 0.028 & 0.505 & 1.54 & 7.78 & 0.031 & 0.144 & 0.073 & $<0.010$ & 0.031 & 0.046 \\
\hline NEPHB-05 & I04LM22 & 2 & 12 & 0.054 & 0.788 & 0.057 & 0.047 & 0.029 & 0.147 & 0.040 & 0.718 & 2.12 & 10.2 & 0.043 & 0.196 & 0.103 & $<0.010$ & 0.046 & 0.082 \\
\hline NEPHB-05 & I04LM12 & 2 & 13 & 0.055 & 0.787 & 0.057 & 0.048 & 0.031 & 0.145 & 0.041 & 0.726 & 2.13 & 10.1 & 0.044 & 0.197 & 0.105 & $<0.010$ & 0.044 & 0.083 \\
\hline NEPHB-03 & I05LM22 & 2 & 14 & 0.043 & 0.629 & 0.035 & 0.041 & 0.025 & 0.115 & 0.031 & 0.577 & 1.74 & 8.48 & 0.032 & 0.167 & 0.082 & $<0.010$ & 0.048 & 0.066 \\
\hline Batch 1 & BCHLM23 & 2 & 15 & 0.126 & 0.832 & $<0.010$ & 0.066 & 0.299 & 2.48 & $<0.010$ & 0.820 & 1.39 & 7.14 & $<0.020$ & $<0.100$ & $<0.010$ & 0.394 & 0.033 & 0.066 \\
\hline Ustd & UstdLM23 & 2 & 16 & $<0.010$ & 0.873 & $<0.010$ & 0.154 & $<0.010$ & 2.39 & $<0.010$ & 0.688 & 2.24 & 9.26 & $<0.020$ & $<0.100$ & 0.048 & 0.556 & $<0.010$ & $<0.010$ \\
\hline
\end{tabular}


Table D3. Measured Elemental Concentrations (wt\%) for Samples Prepared Using Peroxide Fusion

\begin{tabular}{|c|c|c|c|c|c|c|c|c|c|c|}
\hline Glass ID & PSAL ID & Block & $\begin{array}{c}\text { Analytical } \\
\text { Sequence }\end{array}$ & Al & B & $\mathbf{F e}$ & $\mathbf{L i}$ & $\mathrm{Ni}$ & Si & $\mathbf{U}$ \\
\hline Batch 1 & BCHPF11 & 1 & 1 & 2.47 & 2.56 & 8.70 & 2.13 & 0.500 & 22.3 & $<0.100$ \\
\hline Ustd & UstdPF11 & 1 & 2 & 2.12 & 2.91 & 8.80 & 1.40 & 0.716 & 19.6 & 1.88 \\
\hline NEPHB-05 & I04PF21 & 1 & 3 & 6.37 & 2.08 & 9.02 & 1.77 & 0.532 & 17.9 & 3.12 \\
\hline NEPHB-01 & I03PF11 & 1 & 4 & 3.98 & 3.00 & 5.39 & 2.46 & 0.298 & 24.4 & 1.89 \\
\hline NEPHB-03 & I05PF11 & 1 & 5 & 5.27 & 2.58 & 7.27 & 2.13 & 0.426 & 21.3 & 2.38 \\
\hline NEPHB-01 & I03PG21 & 1 & 6 & 3.98 & 2.99 & 5.36 & 2.49 & 0.308 & 24.6 & 1.82 \\
\hline NEPHB-02 & I01PF21 & 1 & 7 & 4.60 & 2.88 & 6.47 & 2.32 & 0.387 & 23.1 & 2.15 \\
\hline Batch 1 & BCHPF12 & 1 & 8 & 2.51 & 2.44 & 9.72 & 2.00 & 0.555 & 23.6 & $<0.100$ \\
\hline Ustd & UstdPF12 & 1 & 9 & 2.14 & 2.84 & 9.74 & 1.40 & 0.794 & 20.7 & 1.88 \\
\hline NEPHB-04 & I02PF21 & 1 & 10 & 5.93 & 2.74 & 8.24 & 2.12 & 0.502 & 20.2 & 2.79 \\
\hline NEPHB-04 & I02PF11 & 1 & 11 & 5.98 & 2.46 & 8.22 & 1.99 & 0.493 & 20.2 & 2.78 \\
\hline NEPHB-02 & I01PF11 & 1 & 12 & 4.57 & 2.86 & 6.34 & 2.28 & 0.371 & 22.9 & 2.13 \\
\hline NEPHB-05 & I04PF11 & 1 & 13 & 6.50 & 2.22 & 9.30 & 1.78 & 0.556 & 18.4 & 3.08 \\
\hline NEPHB-03 & I05PF21 & 1 & 14 & 5.17 & 2.61 & 7.45 & 2.12 & 0.425 & 21.4 & 2.39 \\
\hline Batch 1 & BCHPF13 & 1 & 15 & 2.48 & 2.56 & 9.57 & 2.00 & 0.550 & 23.2 & $<0.100$ \\
\hline Ustd & Ustdpf113 & 1 & 16 & 2.07 & 2.80 & 9.55 & 1.37 & 0.773 & 20.3 & 1.85 \\
\hline Batch 1 & BCHPF21 & 2 & 1 & 2.55 & 2.43 & 9.54 & 2.04 & 0.521 & 23.5 & $<0.100$ \\
\hline Ustd & UstdPF21 & 2 & 2 & 2.25 & 2.95 & 9.32 & 1.41 & 0.748 & 20.4 & 1.98 \\
\hline NEPHB-03 & I05PF22 & 2 & 3 & 5.30 & 2.72 & 7.44 & 2.16 & 0.393 & 21.6 & 2.47 \\
\hline NEPHB-02 & I01PF22 & 2 & 4 & 4.70 & 2.94 & 6.39 & 2.35 & 0.363 & 23.1 & 2.23 \\
\hline NEPHB-04 & I02PF12 & 2 & 5 & 6.07 & 2.43 & 8.08 & 2.02 & 0.467 & 20.1 & 2.76 \\
\hline NEPHB-03 & I05PF12 & 2 & 6 & 5.36 & 2.65 & 7.36 & 2.18 & 0.401 & 21.6 & 2.40 \\
\hline NEPHB-05 & I04PF22 & 2 & 7 & 6.55 & 2.20 & 9.25 & 1.80 & 0.520 & 18.2 & 3.11 \\
\hline Batch 1 & BCHPF22 & 2 & 8 & 2.56 & 2.44 & 9.66 & 2.02 & 0.524 & 23.5 & $<0.100$ \\
\hline Ustd & UstdPF22 & 2 & 9 & 2.16 & 2.85 & 9.69 & 1.41 & 0.772 & 20.5 & 1.93 \\
\hline NEPHB-01 & I03PF22 & 2 & 10 & 4.08 & 3.09 & 5.28 & 2.54 & 0.288 & 24.5 & 1.88 \\
\hline NEPHB-05 & I04PF12 & 2 & 11 & 6.63 & 2.22 & 8.92 & 1.81 & 0.493 & 18.1 & 3.20 \\
\hline NEPHB-04 & I02PF22 & 2 & 12 & 5.98 & 2.62 & 7.76 & 2.12 & 0.442 & 19.8 & 2.80 \\
\hline NEPHB-01 & I03PF12 & 2 & 13 & 4.04 & 3.04 & 5.33 & 2.50 & 0.274 & 24.4 & 1.87 \\
\hline NEPHB-02 & I01PF12 & 2 & 14 & 4.64 & 2.84 & 6.21 & 2.32 & 0.344 & 22.8 & 2.15 \\
\hline Batch 1 & BCHPF23 & 2 & 15 & 2.57 & 2.61 & 9.48 & 2.06 & 0.520 & 23.6 & $<0.100$ \\
\hline Ustd & UstdPF23 & 2 & 16 & 2.18 & 2.82 & 9.47 & 1.42 & 0.757 & 20.5 & 1.91 \\
\hline
\end{tabular}


Table D4. Average Measured and Bias-Corrected Chemical Compositions Versus Targeted Compositions by Oxide by Study Glass

\author{
(100 -Batch 1; 200 -U std)
}

\begin{tabular}{|c|c|c|c|c|c|c|c|c|c|}
\hline Glass ID & Glass \# & Oxide & $\begin{array}{c}\text { Measured } \\
\text { (wt\%) }\end{array}$ & $\begin{array}{c}\text { Measured } \\
\text { Bias-Corrected } \\
(w t \%)\end{array}$ & $\begin{array}{c}\text { Targeted } \\
\text { (wt \%) }\end{array}$ & $\begin{array}{c}\text { Diff of } \\
\text { Measured }\end{array}$ & $\begin{array}{c}\text { Diff of } \\
\text { Meas BC }\end{array}$ & $\begin{array}{l}\text { \% Diff of } \\
\text { Measured }\end{array}$ & $\begin{array}{l}\text { \% Diff of } \\
\text { Meas BC }\end{array}$ \\
\hline NEPHB-01 & 1 & $\mathrm{Al} 2 \mathrm{O} 3(\mathrm{wt} \%)$ & 7.5958 & 7.7702 & 7.4417 & 0.1541 & 0.3285 & $2.1 \%$ & $4.4 \%$ \\
\hline NEPHB-01 & 1 & $\mathrm{~B} 2 \mathrm{O} 3(\mathrm{wt} \%)$ & 9.7563 & 9.4015 & 9.8000 & -0.0437 & -0.3985 & $-0.4 \%$ & $-4.1 \%$ \\
\hline NEPHB-01 & 1 & $\mathrm{BaO}(\mathrm{wt} \%)$ & 0.0360 & 0.0384 & 0.0378 & -0.0018 & 0.0006 & $-4.7 \%$ & $1.7 \%$ \\
\hline NEPHB-01 & 1 & $\mathrm{CaO}(\mathrm{wt} \%)$ & 0.6912 & 0.7327 & 0.7162 & -0.0250 & 0.0165 & $-3.5 \%$ & $2.3 \%$ \\
\hline NEPHB-01 & 1 & $\mathrm{Ce} 2 \mathrm{O} 3(\mathrm{wt} \%)$ & 0.0316 & 0.0316 & 0.0449 & -0.0133 & -0.0133 & $-29.6 \%$ & $-29.6 \%$ \\
\hline NEPHB-01 & 1 & $\mathrm{Cr} 2 \mathrm{O} 3(\mathrm{wt} \%)$ & 0.0358 & 0.0394 & 0.0636 & -0.0278 & -0.0242 & $-43.7 \%$ & $-38.0 \%$ \\
\hline NEPHB-01 & 1 & $\mathrm{CuO}(\mathrm{wt} \%)$ & 0.0238 & 0.0255 & 0.0179 & 0.0059 & 0.0076 & $32.9 \%$ & $42.5 \%$ \\
\hline NEPHB-01 & 1 & $\mathrm{Fe} 2 \mathrm{O} 3(\mathrm{wt} \%)$ & 7.6346 & 7.2606 & 7.9697 & -0.3351 & -0.7091 & $-4.2 \%$ & $-8.9 \%$ \\
\hline NEPHB-01 & 1 & $\mathrm{~K} 2 \mathrm{O}(\mathrm{wt} \%)$ & 0.0979 & 0.1097 & 0.1032 & -0.0053 & 0.0065 & $-5.2 \%$ & $6.3 \%$ \\
\hline NEPHB-01 & 1 & La2O3 (wt $\%)$ & 0.0270 & 0.0270 & 0.0325 & -0.0055 & -0.0055 & $-17.0 \%$ & $-17.0 \%$ \\
\hline NEPHB-01 & 1 & Li2O (wt\%) & 5.3769 & 5.4179 & 5.6000 & -0.2231 & -0.1821 & $-4.0 \%$ & $-3.3 \%$ \\
\hline NEPHB-01 & 1 & $\mathrm{MgO}(\mathrm{wt} \%)$ & 0.7230 & 0.7546 & 0.7486 & -0.0256 & 0.0060 & $-3.4 \%$ & $0.8 \%$ \\
\hline NEPHB-01 & 1 & $\mathrm{MnO}(\mathrm{wt} \%)$ & 1.7463 & 1.6939 & 1.6440 & 0.1023 & 0.0499 & $6.2 \%$ & $3.0 \%$ \\
\hline NEPHB-01 & 1 & $\mathrm{Na} 2 \mathrm{O}(\mathrm{wt} \%)$ & 9.6888 & 9.2666 & 9.4239 & 0.2649 & -0.1573 & $2.8 \%$ & $-1.7 \%$ \\
\hline NEPHB-01 & 1 & $\mathrm{NiO}(\mathrm{wt} \%)$ & 0.3716 & 0.4149 & 0.4731 & -0.1015 & -0.0582 & $-21.5 \%$ & $-12.3 \%$ \\
\hline NEPHB-01 & 1 & $\mathrm{PbO}(\mathrm{wt} \%)$ & 0.0372 & 0.0372 & 0.0271 & 0.0101 & 0.0101 & $37.1 \%$ & $37.1 \%$ \\
\hline NEPHB-01 & 1 & SO4 (wt $\%)$ & 0.3812 & 0.3812 & 0.4014 & -0.0202 & -0.0202 & $-5.0 \%$ & $-5.0 \%$ \\
\hline NEPHB-01 & 1 & $\mathrm{SiO} 2(\mathrm{wt} \%)$ & 52.3594 & 52.7970 & 53.0340 & -0.6746 & -0.2370 & $-1.3 \%$ & $-0.4 \%$ \\
\hline NEPHB-01 & 1 & ThO2 (wt $\%)$ & 0.0708 & 0.0708 & 0.0197 & 0.0511 & 0.0511 & $259.6 \%$ & $259.6 \%$ \\
\hline NEPHB-01 & 1 & TiO2 (wt\%) & 0.0083 & 0.0086 & 0.0080 & 0.0003 & 0.0006 & $4.3 \%$ & $7.9 \%$ \\
\hline NEPHB-01 & 1 & U3O8 (wt\%) & 2.1992 & 2.3560 & 2.2921 & -0.0929 & 0.0639 & $-4.1 \%$ & $2.8 \%$ \\
\hline NEPHB-01 & 1 & $\mathrm{ZnO}(\mathrm{wt} \%)$ & 0.0411 & 0.0411 & 0.0293 & 0.0118 & 0.0118 & $40.2 \%$ & $40.2 \%$ \\
\hline NEPHB-01 & 1 & $\mathrm{ZrO} 2(\mathrm{wt} \%)$ & 0.0544 & 0.0544 & 0.0711 & -0.0167 & -0.0167 & $-23.5 \%$ & $-23.5 \%$ \\
\hline NEPHB-01 & 1 & Sum $(w t \%)$ & 98.9881 & 98.7310 & 99.9998 & -1.0117 & -1.2688 & $-1.0 \%$ & $-1.3 \%$ \\
\hline & & & & & & & & & \\
\hline NEPHB-02 & 2 & $\mathrm{Al} 2 \mathrm{O} 3(\mathrm{wt} \%)$ & 8.7437 & 8.9445 & 8.6820 & 0.0617 & 0.2625 & $0.7 \%$ & $3.0 \%$ \\
\hline NEPHB-02 & 2 & B2O3 (wt\%) & 9.2733 & 8.9357 & 9.1000 & 0.1733 & -0.1643 & $1.9 \%$ & $-1.8 \%$ \\
\hline NEPHB-02 & 2 & $\mathrm{BaO}(\mathrm{wt} \%)$ & 0.0413 & 0.0441 & 0.0441 & -0.0028 & 0.0000 & $-6.3 \%$ & $0.0 \%$ \\
\hline NEPHB-02 & 2 & $\mathrm{CaO}(\mathrm{wt} \%)$ & 0.7650 & 0.8110 & 0.8356 & -0.0706 & -0.0246 & $-8.4 \%$ & $-2.9 \%$ \\
\hline NEPHB-02 & 2 & $\mathrm{Ce} 2 \mathrm{O} 3(\mathrm{wt} \%)$ & 0.0454 & 0.0454 & 0.0524 & -0.0070 & -0.0070 & $-13.4 \%$ & $-13.4 \%$ \\
\hline NEPHB-02 & 2 & $\mathrm{Cr} 2 \mathrm{O} 3(\mathrm{wt} \%)$ & 0.0537 & 0.0591 & 0.0742 & -0.0205 & -0.0151 & $-27.6 \%$ & $-20.3 \%$ \\
\hline NEPHB-02 & 2 & $\mathrm{CuO}(\mathrm{wt} \%)$ & 0.0266 & 0.0285 & 0.0209 & 0.0057 & 0.0076 & $27.3 \%$ & $36.5 \%$ \\
\hline NEPHB-02 & 2 & $\mathrm{Fe} 2 \mathrm{O} 3(\mathrm{wt} \%)$ & 9.0822 & 8.6374 & 9.2979 & -0.2157 & -0.6605 & $-2.3 \%$ & $-7.1 \%$ \\
\hline NEPHB-02 & 2 & $\mathrm{~K} 2 \mathrm{O}(\mathrm{wt} \%)$ & 0.1220 & 0.1367 & 0.1204 & 0.0016 & 0.0163 & $1.3 \%$ & $13.6 \%$ \\
\hline NEPHB-02 & 2 & $\mathrm{La} 2 \mathrm{O} 3(\mathrm{wt} \%)$ & 0.0328 & 0.0328 & 0.0379 & -0.0051 & -0.0051 & $-13.4 \%$ & $-13.4 \%$ \\
\hline NEPHB-02 & 2 & $\mathrm{Li} 2 \mathrm{O}(\mathrm{wt} \%)$ & 4.9893 & 5.0274 & 5.2000 & -0.2107 & -0.1726 & $-4.1 \%$ & $-3.3 \%$ \\
\hline NEPHB-02 & 2 & $\mathrm{MgO}(\mathrm{wt} \%)$ & 0.8329 & 0.8693 & 0.8734 & -0.0405 & -0.0041 & $-4.6 \%$ & $-0.5 \%$ \\
\hline NEPHB-02 & 2 & $\mathrm{MnO}(\mathrm{wt} \%)$ & 1.9820 & 1.9224 & 1.9180 & 0.0640 & 0.0044 & $3.3 \%$ & $0.2 \%$ \\
\hline NEPHB-02 & 2 & $\mathrm{Na} 2 \mathrm{O}(\mathrm{wt} \%)$ & 10.3223 & 9.8725 & 10.3279 & -0.0056 & -0.4554 & $-0.1 \%$ & $-4.4 \%$ \\
\hline NEPHB-02 & 2 & $\mathrm{NiO}\left(\mathrm{wt}^{2} \%\right)$ & 0.4661 & 0.5205 & 0.5520 & -0.0859 & -0.0315 & $-15.6 \%$ & $-5.7 \%$ \\
\hline NEPHB-02 & 2 & $\mathrm{PbO}(\mathrm{wt} \%)$ & 0.0331 & 0.0331 & 0.0317 & 0.0014 & 0.0014 & $4.5 \%$ & $4.5 \%$ \\
\hline NEPHB-02 & 2 & SO4 (wt $\%)$ & 0.4367 & 0.4367 & 0.4683 & -0.0316 & -0.0316 & $-6.8 \%$ & $-6.8 \%$ \\
\hline NEPHB-02 & 2 & $\mathrm{SiO} 2(\mathrm{wt} \%)$ & 49.1504 & 49.5612 & 49.5396 & -0.3892 & 0.0216 & $-0.8 \%$ & $0.0 \%$ \\
\hline NEPHB-02 & 2 & ThO2 (wt $\%)$ & 0.0816 & 0.0816 & 0.0230 & 0.0586 & 0.0586 & $255.0 \%$ & $255.0 \%$ \\
\hline NEPHB-02 & 2 & $\mathrm{TiO} 2(\mathrm{wt} \%)$ & 0.0083 & 0.0086 & 0.0093 & -0.0010 & -0.0007 & $-10.3 \%$ & $-7.2 \%$ \\
\hline NEPHB-02 & 2 & U3O8 (wt\%) & 2.5530 & 2.7347 & 2.6741 & -0.1211 & 0.0606 & $-4.5 \%$ & $2.3 \%$ \\
\hline NEPHB-02 & 2 & $\mathrm{ZnO}(\mathrm{wt} \%)$ & 0.0392 & 0.0392 & 0.0342 & 0.0050 & 0.0050 & $14.7 \%$ & $14.7 \%$ \\
\hline NEPHB-02 & 2 & $\mathrm{ZrO} 2(\mathrm{wt} \%)$ & 0.0625 & 0.0625 & 0.0830 & -0.0205 & -0.0205 & $-24.7 \%$ & $-24.7 \%$ \\
\hline NEPHB-02 & 2 & Sum $(w t \%)$ & 99.1434 & 98.8451 & 99.9999 & -0.8565 & -1.1548 & $-0.9 \%$ & $-1.2 \%$ \\
\hline & & & & & & & & & \\
\hline NEPHB-03 & 3 & $\mathrm{~A} 12 \mathrm{O} 3(\mathrm{wt} \%)$ & 9.9671 & 10.1959 & 9.9223 & 0.0448 & 0.2736 & $0.5 \%$ & $2.8 \%$ \\
\hline NEPHB-03 & 3 & $\mathrm{~B} 2 \mathrm{O} 3(\mathrm{wt} \%)$ & 8.5005 & 8.1916 & 8.4000 & 0.1005 & -0.2084 & $1.2 \%$ & $-2.5 \%$ \\
\hline NEPHB-03 & 3 & $\mathrm{BaO}(\mathrm{wt} \%)$ & 0.0483 & 0.0516 & 0.0504 & -0.0021 & 0.0012 & $-4.2 \%$ & $2.3 \%$ \\
\hline NEPHB-03 & 3 & $\mathrm{CaO}(\mathrm{wt} \%)$ & 0.8829 & 0.9360 & 0.9550 & -0.0721 & $\begin{array}{l}-0.0190 \\
\end{array}$ & $-7.6 \%$ & $-2.0 \%$ \\
\hline NEPHB-03 & 3 & $\mathrm{Ce} 2 \mathrm{O} 3(\mathrm{wt} \%)$ & 0.0407 & 0.0407 & 0.0599 & -0.0192 & -0.0192 & $-32.0 \%$ & $-32.0 \%$ \\
\hline
\end{tabular}


Table D4. Average Measured and Bias-Corrected Chemical Compositions Versus Targeted Compositions by Oxide by Study Glass (continued)

(100-Batch 1; $200-U$ std)

\begin{tabular}{|c|c|c|c|c|c|c|c|c|c|}
\hline Glass ID & Glass \# & Oxide & $\begin{array}{c}\text { Measured } \\
\text { (wt\%) }\end{array}$ & $\begin{array}{c}\text { Measured } \\
\text { Bias-Corrected } \\
(\mathrm{wt} \%)\end{array}$ & $\begin{array}{c}\text { Targeted } \\
\text { (wt\%) }\end{array}$ & $\begin{array}{c}\text { Diff of } \\
\text { Measured }\end{array}$ & $\begin{array}{c}\text { Diff of } \\
\text { Meas BC }\end{array}$ & $\begin{array}{l}\text { \% Diff of } \\
\text { Measured }\end{array}$ & $\begin{array}{l}\text { \% Diff of } \\
\text { Meas BC }\end{array}$ \\
\hline NEPHB-03 & 3 & $\mathrm{Cr} 2 \mathrm{O} 3(\mathrm{wt} \%)$ & 0.0607 & 0.0668 & 0.0848 & $\begin{array}{ll}-0.0241 \\
\end{array}$ & -0.0180 & $-28.5 \%$ & $-21.3 \%$ \\
\hline NEPHB-03 & 3 & $\mathrm{CuO}\left(\mathrm{wt}^{\circ} \%\right)$ & 0.0316 & 0.0339 & 0.0239 & 0.0077 & 0.0100 & $32.3 \%$ & $41.9 \%$ \\
\hline NEPHB-03 & 3 & $\mathrm{Fe} 2 \mathrm{O} 3(\mathrm{wt} \%)$ & 10.5512 & 10.0331 & 10.6262 & -0.0750 & -0.5931 & $-0.7 \%$ & $-5.6 \%$ \\
\hline NEPHB-03 & 3 & $\mathrm{~K} 2 \mathrm{O}(\mathrm{wt} \%)$ & 0.1397 & 0.1567 & 0.1376 & 0.0021 & 0.0191 & $1.6 \%$ & $13.9 \%$ \\
\hline NEPHB-03 & 3 & La2O3 (wt $\%)$ & 0.0367 & 0.0367 & 0.0434 & -0.0068 & -0.0068 & $-15.6 \%$ & $-15.6 \%$ \\
\hline NEPHB-03 & 3 & $\mathrm{Li} 2 \mathrm{O}(\mathrm{wt} \%)$ & 4.6234 & 4.6586 & 4.8000 & -0.1766 & -0.1414 & $-3.7 \%$ & $-2.9 \%$ \\
\hline NEPHB-03 & 3 & $\mathrm{MgO}(\mathrm{wt} \%)$ & 0.9622 & 1.0043 & 0.9982 & -0.0360 & 0.0061 & $-3.6 \%$ & $0.6 \%$ \\
\hline NEPHB-03 & 3 & $\mathrm{MnO}(\mathrm{wt} \%)$ & 2.2596 & 2.1914 & 2.1920 & 0.0676 & -0.0006 & $3.1 \%$ & $0.0 \%$ \\
\hline NEPHB-03 & 3 & $\mathrm{Na} 2 \mathrm{O}(\mathrm{wt} \%)$ & 11.3266 & 10.8344 & 11.2318 & 0.0948 & -0.3974 & $0.8 \%$ & $-3.5 \%$ \\
\hline NEPHB-03 & 3 & $\mathrm{NiO}\left(\mathrm{wt}^{2} \%\right)$ & 0.5233 & 0.5844 & 0.6308 & -0.1075 & -0.0464 & $-17.0 \%$ & $-7.4 \%$ \\
\hline NEPHB-03 & 3 & $\mathrm{PbO}(\mathrm{wt} \%)$ & 0.0350 & 0.0350 & 0.0362 & -0.0012 & -0.0012 & $-3.3 \%$ & $-3.3 \%$ \\
\hline NEPHB-03 & 3 & SO4 (wt $\%)$ & 0.5011 & 0.5011 & 0.5352 & -0.0341 & -0.0341 & $-6.4 \%$ & $-6.4 \%$ \\
\hline NEPHB-03 & 3 & $\mathrm{SiO} 2(\mathrm{wt} \%)$ & 45.9415 & 46.3220 & 46.0453 & -0.1038 & 0.2767 & $-0.2 \%$ & $0.6 \%$ \\
\hline NEPHB-03 & 3 & ThO2 (wt\%) & 0.0933 & 0.0933 & 0.0263 & 0.0670 & 0.0670 & $254.8 \%$ & $254.8 \%$ \\
\hline NEPHB-03 & 3 & $\mathrm{TiO} 2(\mathrm{wt} \%)$ & 0.0083 & 0.0086 & 0.0107 & -0.0024 & -0.0021 & $-22.1 \%$ & $-19.3 \%$ \\
\hline NEPHB-03 & 3 & U3O8 (wt\%) & 2.8419 & 3.0443 & 3.0561 & -0.2142 & $\begin{array}{l}-0.0118 \\
\end{array}$ & $-7.0 \%$ & $-0.4 \%$ \\
\hline NEPHB-03 & 3 & $\mathrm{ZnO}(\mathrm{wt} \%)$ & 0.0582 & 0.0582 & 0.0390 & 0.0192 & 0.0192 & $49.2 \%$ & $49.2 \%$ \\
\hline NEPHB-03 & 3 & $\mathrm{ZrO} 2(\mathrm{wt} \%)$ & 0.0898 & 0.0898 & 0.0948 & -0.0050 & -0.0050 & $-5.2 \%$ & $-5.2 \%$ \\
\hline NEPHB-03 & 3 & Sum (wt $\%)$ & 99.5235 & 99.1684 & 99.9999 & -0.4764 & -0.8315 & $-0.5 \%$ & $-0.8 \%$ \\
\hline & & & & & & & & & \\
\hline NEPHB-04 & 4 & $\mathrm{Al} 2 \mathrm{O} 3(\mathrm{wt} \%)$ & 11.3181 & 11.5787 & 11.1626 & 0.1555 & 0.4161 & $1.4 \%$ & $3.7 \%$ \\
\hline NEPHB-04 & 4 & B2O3 (wt $\%)$ & 8.2510 & 7.9498 & 7.7000 & 0.5510 & 0.2498 & $7.2 \%$ & $3.2 \%$ \\
\hline NEPHB-04 & 4 & $\mathrm{BaO}(\mathrm{wt} \%)$ & 0.0519 & 0.0554 & 0.0567 & -0.0048 & -0.0013 & $-8.4 \%$ & $-2.2 \%$ \\
\hline NEPHB-04 & 4 & $\mathrm{CaO}\left(\mathrm{wt}^{\circ} \%\right)$ & 0.9738 & 1.0324 & 1.0743 & -0.1005 & -0.0419 & $-9.4 \%$ & $-3.9 \%$ \\
\hline NEPHB-04 & 4 & $\mathrm{Ce} 2 \mathrm{O} 3(\mathrm{wt} \%)$ & 0.0518 & 0.0518 & 0.0674 & -0.0156 & -0.0156 & $-23.1 \%$ & $-23.1 \%$ \\
\hline NEPHB-04 & 4 & $\mathrm{Cr} 2 \mathrm{O} 3(\mathrm{wt} \%)$ & 0.0636 & 0.0700 & 0.0954 & -0.0318 & -0.0254 & $-33.4 \%$ & $-26.6 \%$ \\
\hline NEPHB-04 & 4 & $\mathrm{CuO}(\mathrm{wt} \%)$ & 0.0391 & 0.0420 & 0.0269 & 0.0122 & 0.0151 & $45.4 \%$ & $56.0 \%$ \\
\hline NEPHB-04 & 4 & $\mathrm{Fe} 2 \mathrm{O} 3(\mathrm{wt} \%)$ & 11.5448 & 10.9809 & 11.9545 & -0.4097 & -0.9736 & $-3.4 \%$ & $-8.1 \%$ \\
\hline NEPHB-04 & 4 & $\mathrm{~K} 2 \mathrm{O}(\mathrm{wt} \%)$ & 0.1602 & 0.1796 & 0.1548 & 0.0054 & 0.0248 & $3.5 \%$ & $16.0 \%$ \\
\hline NEPHB-04 & 4 & La2O3 (wt\%) & 0.0428 & 0.0428 & 0.0488 & -0.0060 & -0.0060 & $-12.3 \%$ & $-12.3 \%$ \\
\hline NEPHB-04 & 4 & $\mathrm{Li} 2 \mathrm{O}(\mathrm{wt} \%)$ & 4.4404 & 4.4742 & 4.4000 & 0.0404 & 0.0742 & $0.9 \%$ & $1.7 \%$ \\
\hline NEPHB-04 & 4 & $\mathrm{MgO}(\mathrm{wt} \%)$ & 1.0646 & 1.1112 & 1.1229 & -0.0583 & -0.0117 & $-5.2 \%$ & $-1.0 \%$ \\
\hline NEPHB-04 & 4 & $\mathrm{MnO}(\mathrm{wt} \%)$ & 2.5533 & 2.4765 & 2.4660 & 0.0873 & 0.0105 & $3.5 \%$ & $0.4 \%$ \\
\hline NEPHB-04 & 4 & $\mathrm{Na} 2 \mathrm{O}(\mathrm{wt} \%)$ & 12.3949 & 11.8544 & 12.1358 & 0.2591 & -0.2814 & $2.1 \%$ & $-2.3 \%$ \\
\hline NEPHB-04 & 4 & $\mathrm{NiO}(\mathrm{wt} \%)$ & 0.6057 & 0.6763 & 0.7097 & -0.1040 & -0.0334 & $-14.7 \%$ & $-4.7 \%$ \\
\hline NEPHB-04 & 4 & $\mathrm{PbO}(\mathrm{wt} \%)$ & 0.0399 & 0.0399 & 0.0407 & -0.0008 & -0.0008 & $-2.1 \%$ & $-2.1 \%$ \\
\hline NEPHB-04 & 4 & SO4 (wt $\%)$ & 0.5423 & 0.5423 & 0.6021 & -0.0598 & -0.0598 & $-9.9 \%$ & $-9.9 \%$ \\
\hline NEPHB-04 & 4 & $\mathrm{SiO} 2(\mathrm{wt} \%)$ & 42.9464 & 43.3078 & 42.5509 & 0.3955 & 0.7569 & $0.9 \%$ & $1.8 \%$ \\
\hline NEPHB-04 & 4 & ThO2 (wt\%) & 0.1007 & 0.1007 & 0.0296 & 0.0711 & 0.0711 & $240.2 \%$ & $240.2 \%$ \\
\hline NEPHB-04 & 4 & $\mathrm{TiO} 2(\mathrm{wt} \%)$ & 0.0083 & 0.0086 & 0.0120 & -0.0037 & -0.0034 & $-30.5 \%$ & $-28.1 \%$ \\
\hline NEPHB-04 & 4 & $\mathrm{U} 3 \mathrm{O} 8(\mathrm{wt} \%)$ & 3.2811 & 3.5155 & 3.4381 & -0.1570 & 0.0774 & $-4.6 \%$ & $2.3 \%$ \\
\hline NEPHB-04 & 4 & $\mathrm{ZnO}(\mathrm{wt} \%)$ & 0.0678 & 0.0678 & 0.0439 & 0.0239 & 0.0239 & $54.5 \%$ & $54.5 \%$ \\
\hline NEPHB-04 & 4 & $\mathrm{ZrO} 2(\mathrm{wt} \%)$ & 0.0939 & 0.0939 & 0.1067 & -0.0128 & -0.0128 & $-12.0 \%$ & $-12.0 \%$ \\
\hline NEPHB-04 & 4 & Sum (wt $\%)$ & 100.6366 & 100.2526 & 99.9998 & 0.6368 & 0.2528 & $0.6 \%$ & $0.3 \%$ \\
\hline & & & & & & & & & \\
\hline NEPHB-05 & 5 & $\mathrm{Al} 2 \mathrm{O} 3(\mathrm{wt} \%)$ & $\begin{array}{l}12.3054 \\
\end{array}$ & 12.5876 & 12.4029 & -0.0975 & 0.1847 & $-0.8 \%$ & $1.5 \%$ \\
\hline NEPHB-05 & 5 & $\mathrm{~B} 2 \mathrm{O} 3(\mathrm{wt} \%)$ & 7.0194 & 6.7642 & 7.0000 & 0.0194 & -0.2358 & $0.3 \%$ & $-3.4 \%$ \\
\hline NEPHB-05 & 5 & $\mathrm{BaO}(\mathrm{wt} \%)$ & 0.0608 & 0.0650 & 0.0630 & -0.0022 & 0.0020 & $-3.4 \%$ & $3.1 \%$ \\
\hline NEPHB-05 & 5 & $\mathrm{CaO}(\mathrm{wt} \%)$ & 1.0928 & 1.1584 & 1.1937 & -0.1009 & -0.0353 & $-8.5 \%$ & $-3.0 \%$ \\
\hline NEPHB-05 & 5 & $\mathrm{Ce} 2 \mathrm{O} 3(\mathrm{wt} \%)$ & 0.0665 & 0.0665 & 0.0749 & -0.0084 & -0.0084 & $-11.3 \%$ & $-11.3 \%$ \\
\hline NEPHB-05 & 5 & $\mathrm{Cr} 2 \mathrm{O} 3(\mathrm{wt} \%)$ & 0.0702 & 0.0772 & 0.1061 & -0.0359 & -0.0289 & $-33.9 \%$ & $-27.2 \%$ \\
\hline NEPHB-05 & 5 & $\mathrm{CuO}(\mathrm{wt} \%)$ & 0.0372 & 0.0399 & 0.0299 & 0.0073 & 0.0100 & $24.6 \%$ & $33.6 \%$ \\
\hline NEPHB-05 & 5 & Fe2O3 (wt $\%)$ & 13.0424 & 12.4031 & 13.2827 & -0.2403 & -0.8796 & $-1.8 \%$ & $-6.6 \%$ \\
\hline NEPHB-05 & 5 & $\mathrm{~K} 2 \mathrm{O}(\mathrm{wt} \%)$ & 0.1759 & 0.1972 & 0.1721 & 0.0038 & 0.0251 & $2.2 \%$ & $14.6 \%$ \\
\hline NEPHB-05 & 5 & $\mathrm{La} 2 \mathrm{O} 3(\mathrm{wt} \%)$ & 0.0478 & 0.0478 & 0.0542 & -0.0064 & -0.0064 & $-11.8 \%$ & $-11.8 \%$ \\
\hline NEPHB-05 & 5 & $\mathrm{Li} 2 \mathrm{O}(\mathrm{wt} \%)$ & 3.8537 & 3.8831 & 4.0000 & -0.1463 & -0.1169 & $-3.7 \%$ & $-2.9 \%$ \\
\hline
\end{tabular}


Table D4. Average Measured and Bias-Corrected Chemical Compositions Versus Targeted Compositions by Oxide by Study Glass (continued)

(100 -Batch 1; 200 -U std)

\begin{tabular}{|c|c|c|c|c|c|c|c|c|c|}
\hline Glass ID & Glass \# & Oxide & $\begin{array}{c}\text { Measured } \\
\text { (wt\%) }\end{array}$ & $\begin{array}{c}\text { Measured } \\
\text { Bias-Corrected } \\
(\mathrm{wt} \%)\end{array}$ & $\begin{array}{c}\text { Targeted } \\
\text { (wt\%) }\end{array}$ & $\begin{array}{c}\text { Diff of } \\
\text { Measured }\end{array}$ & $\begin{array}{c}\text { Diff of } \\
\text { Meas BC }\end{array}$ & $\begin{array}{l}\text { \% Diff of } \\
\text { Measured }\end{array}$ & $\begin{array}{l}\text { \% Diff of } \\
\text { Meas BC }\end{array}$ \\
\hline NEPHB-05 & 5 & $\mathrm{MgO}(\mathrm{wt} \%)$ & 1.1894 & 1.2414 & 1.2477 & -0.0583 & -0.0063 & $-4.7 \%$ & $-0.5 \%$ \\
\hline NEPHB-05 & 5 & $\mathrm{MnO}(\mathrm{wt} \%)$ & 2.7987 & 2.7147 & 2.7401 & 0.0586 & -0.0254 & $2.1 \%$ & $-0.9 \%$ \\
\hline NEPHB-05 & 5 & $\mathrm{Na} 2 \mathrm{O}(\mathrm{wt} \%)$ & 13.4092 & 12.8237 & 13.0398 & 0.3694 & -0.2161 & $2.8 \%$ & $-1.7 \%$ \\
\hline NEPHB-05 & 5 & $\mathrm{NiO}(\mathrm{wt} \%)$ & 0.6684 & 0.7464 & 0.7886 & -0.1202 & -0.0422 & $-15.2 \%$ & $-5.4 \%$ \\
\hline NEPHB-05 & 5 & $\mathrm{PbO}(\mathrm{wt} \%)$ & 0.0471 & 0.0471 & 0.0452 & 0.0019 & 0.0019 & $4.3 \%$ & $4.3 \%$ \\
\hline NEPHB-05 & 5 & SO4 (wt $\%)$ & 0.5894 & 0.5894 & 0.6690 & -0.0796 & -0.0796 & $-11.9 \%$ & $-11.9 \%$ \\
\hline NEPHB-05 & 5 & $\mathrm{SiO} 2(\mathrm{wt} \%)$ & 38.8283 & 39.1524 & 39.0566 & -0.2283 & 0.0958 & $-0.6 \%$ & $0.2 \%$ \\
\hline NEPHB-05 & 5 & ThO2 (wt $\%)$ & 0.1178 & 0.1178 & 0.0329 & 0.0849 & 0.0849 & $258.0 \%$ & $258.0 \%$ \\
\hline NEPHB-05 & 5 & $\mathrm{TiO} 2(\mathrm{wt} \%)$ & 0.0083 & 0.0086 & 0.0133 & -0.0050 & -0.0047 & $-37.3 \%$ & $-35.1 \%$ \\
\hline NEPHB-05 & 5 & U3O8 (wt\%) & 3.6879 & 3.9507 & 3.8201 & -0.1322 & 0.1306 & $-3.5 \%$ & $3.4 \%$ \\
\hline NEPHB-05 & 5 & $\mathrm{ZnO}(\mathrm{wt} \%)$ & 0.0566 & 0.0566 & 0.0488 & 0.0078 & 0.0078 & $16.1 \%$ & $16.1 \%$ \\
\hline NEPHB-05 & 5 & $\mathrm{ZrO} 2(\mathrm{wt} \%)$ & 0.1114 & 0.1114 & 0.1185 & -0.0071 & -0.0071 & $-6.0 \%$ & $-6.0 \%$ \\
\hline NEPHB-05 & 5 & Sum $(\mathrm{wt} \%)$ & 99.2847 & 98.8503 & 100.0001 & -0.7154 & -1.1498 & $-0.7 \%$ & $-1.1 \%$ \\
\hline & & & & & & & & & \\
\hline Batch 1 & 100 & $\mathrm{Al} 2 \mathrm{O} 3(\mathrm{wt} \%)$ & 4.7678 & 4.8770 & 4.8770 & -0.1092 & 0.0000 & $-2.2 \%$ & $0.0 \%$ \\
\hline Batch 1 & 100 & B2O3 (wt $\%)$ & 8.0712 & 7.7770 & 7.7770 & 0.2942 & 0.0000 & $3.8 \%$ & $0.0 \%$ \\
\hline Batch 1 & 100 & $\mathrm{BaO}(\mathrm{wt} \%)$ & 0.1414 & 0.1510 & 0.1510 & -0.0096 & 0.0000 & $-6.3 \%$ & $0.0 \%$ \\
\hline Batch 1 & 100 & $\mathrm{CaO}(\mathrm{wt} \%)$ & 1.1508 & 1.2200 & 1.2200 & $\begin{array}{l}-0.0692 \\
\end{array}$ & 0.0000 & $-5.7 \%$ & $0.0 \%$ \\
\hline Batch 1 & 100 & $\mathrm{Ce} 2 \mathrm{O} 3(\mathrm{wt} \%)$ & 0.0059 & 0.0059 & 0.0000 & 0.0059 & 0.0059 & & \\
\hline Batch 1 & 100 & Cr2O3 (wt $\%)$ & 0.0972 & 0.1070 & 0.1070 & -0.0098 & 0.0000 & $-9.2 \%$ & $0.0 \%$ \\
\hline Batch 1 & 100 & $\mathrm{CuO}(\mathrm{wt} \%)$ & 0.3720 & 0.3990 & 0.3990 & $\begin{array}{l}-0.0270 \\
\end{array}$ & 0.0000 & $-6.8 \%$ & $0.0 \%$ \\
\hline Batch 1 & 100 & $\mathrm{Fe} 2 \mathrm{O} 3(\mathrm{wt} \%)$ & 13.5035 & 12.8390 & 12.8390 & 0.6645 & 0.0000 & $5.2 \%$ & $0.0 \%$ \\
\hline Batch 1 & 100 & $\mathrm{~K} 2 \mathrm{O}(\mathrm{wt} \%)$ & 2.9673 & 3.3270 & 3.3270 & -0.3597 & 0.0000 & $-10.8 \%$ & $0.0 \%$ \\
\hline Batch 1 & 100 & La2O3 (wt $\%)$ & 0.0059 & 0.0059 & 0.0000 & 0.0059 & 0.0059 & & \\
\hline Batch 1 & 100 & $\mathrm{Li} 2 \mathrm{O}(\mathrm{wt} \%)$ & 4.3955 & 4.4290 & 4.4290 & -0.0335 & 0.0000 & $-0.8 \%$ & $0.0 \%$ \\
\hline Batch 1 & 100 & $\mathrm{MgO}(\mathrm{wt} \%)$ & 1.3595 & 1.4190 & 1.4190 & -0.0595 & 0.0000 & $-4.2 \%$ & $0.0 \%$ \\
\hline Batch 1 & 100 & $\mathrm{MnO}(\mathrm{wt} \%)$ & 1.7797 & 1.7260 & 1.7260 & 0.0537 & 0.0000 & $3.1 \%$ & $0.0 \%$ \\
\hline Batch 1 & 100 & $\mathrm{Na} 2 \mathrm{O}(\mathrm{wt} \%)$ & 9.4135 & 9.0030 & 9.0030 & 0.4105 & 0.0000 & $4.6 \%$ & $0.0 \%$ \\
\hline Batch 1 & 100 & $\mathrm{NiO}(\mathrm{wt} \%)$ & 0.6723 & 0.7510 & 0.7510 & -0.0787 & 0.0000 & $-10.5 \%$ & $0.0 \%$ \\
\hline Batch 1 & 100 & $\mathrm{PbO}(\mathrm{wt} \%)$ & 0.0108 & 0.0108 & 0.0000 & 0.0108 & 0.0108 & & \\
\hline Batch 1 & 100 & SO4 (wt \%) & 0.1498 & 0.1498 & 0.0000 & 0.1498 & 0.1498 & & \\
\hline Batch 1 & 100 & $\mathrm{SiO} 2(\mathrm{wt} \%)$ & 49.8100 & 50.2200 & 50.2200 & -0.4100 & 0.0000 & $-0.8 \%$ & $0.0 \%$ \\
\hline Batch 1 & 100 & ThO2 (wt\%) & 0.0057 & 0.0057 & 0.0000 & 0.0057 & 0.0057 & & \\
\hline Batch 1 & 100 & $\mathrm{TiO} 2(\mathrm{wt} \%)$ & 0.6541 & 0.6770 & 0.6770 & -0.0229 & 0.0000 & $-3.4 \%$ & $0.0 \%$ \\
\hline Batch 1 & 100 & $\mathrm{U} 3 \mathrm{O} 8(\mathrm{wt} \%)$ & 0.0590 & 0.0632 & 0.0000 & 0.0590 & 0.0632 & & \\
\hline Batch 1 & 100 & $\mathrm{ZnO}(\mathrm{wt} \%)$ & 0.0425 & 0.0425 & 0.0000 & 0.0425 & 0.0425 & & \\
\hline Batch 1 & 100 & $\mathrm{ZrO} 2(\mathrm{wt} \%)$ & 0.0894 & 0.0894 & 0.0980 & -0.0086 & -0.0086 & $-8.8 \%$ & $-8.8 \%$ \\
\hline Batch 1 & 100 & Sum (wt \%) & 99.5249 & 99.2951 & 99.0200 & 0.5049 & 0.2751 & $0.5 \%$ & $0.3 \%$ \\
\hline & & & & & & & & & \\
\hline Ustd & 200 & $\mathrm{Al} 2 \mathrm{O} 3(\mathrm{wt} \%)$ & 4.0687 & 4.1615 & 4.1000 & -0.0313 & 0.0615 & $-0.8 \%$ & $1.5 \%$ \\
\hline Ustd & 200 & $\mathrm{~B} 2 \mathrm{O} 3(\mathrm{wt} \%)$ & 9.2143 & 8.8788 & 9.2090 & 0.0053 & -0.3302 & $0.1 \%$ & $-3.6 \%$ \\
\hline Ustd & 200 & $\mathrm{BaO}(\mathrm{wt} \%)$ & 0.0056 & 0.0060 & 0.0000 & 0.0056 & 0.0060 & & \\
\hline Ustd & 200 & $\mathrm{CaO}\left(\mathrm{wt}^{\circ} \%\right)$ & 1.2208 & 1.2942 & 1.3010 & -0.0802 & -0.0068 & $-6.2 \%$ & $-0.5 \%$ \\
\hline Ustd & 200 & $\mathrm{Ce} 2 \mathrm{O} 3(\mathrm{wt} \%)$ & 0.0059 & 0.0059 & 0.0000 & 0.0059 & 0.0059 & & \\
\hline Ustd & 200 & Cr2O3 (wt $\%)$ & 0.2248 & 0.2475 & 0.0000 & 0.2248 & 0.2475 & & \\
\hline Ustd & 200 & $\mathrm{CuO}(\mathrm{wt} \%)$ & 0.0063 & 0.0067 & 0.0000 & 0.0063 & 0.0067 & & \\
\hline Ustd & 200 & Fe2O3 (wt $\%)$ & 13.4797 & 12.8172 & 13.1960 & 0.2837 & -0.3788 & $2.1 \%$ & $-2.9 \%$ \\
\hline Ustd & 200 & $\mathrm{~K} 2 \mathrm{O}(\mathrm{wt} \%)$ & 2.8549 & 3.2009 & 2.9990 & -0.1441 & 0.2019 & $-4.8 \%$ & $6.7 \%$ \\
\hline Ustd & 200 & La2O3 (wt\%) & 0.0059 & 0.0059 & 0.0000 & 0.0059 & 0.0059 & & \\
\hline Ustd & 200 & $\mathrm{Li} 2 \mathrm{O}(\mathrm{wt} \%)$ & 3.0176 & 3.0407 & 3.0570 & -0.0394 & -0.0163 & $-1.3 \%$ & $-0.5 \%$ \\
\hline Ustd & 200 & $\mathrm{MgO}(\mathrm{wt} \%)$ & 1.1246 & 1.1738 & 1.2100 & -0.0854 & -0.0362 & $-7.1 \%$ & $-3.0 \%$ \\
\hline Ustd & 200 & $\mathrm{MnO}(\mathrm{wt} \%)$ & 2.9117 & 2.8239 & 2.8920 & 0.0197 & -0.0681 & $0.7 \%$ & $-2.4 \%$ \\
\hline Ustd & 200 & $\mathrm{Na} 2 \mathrm{O}(\mathrm{wt} \%)$ & 12.3432 & 11.8060 & 11.7950 & 0.5482 & 0.0110 & $4.6 \%$ & $0.1 \%$ \\
\hline Ustd & 200 & $\mathrm{NiO}(\mathrm{wt} \%)$ & 0.9671 & 1.0805 & 1.1200 & -0.1529 & -0.0395 & $-13.7 \%$ & $-3.5 \%$ \\
\hline Ustd & 200 & $\mathrm{PbO}(\mathrm{wt} \%)$ & 0.0108 & 0.0108 & 0.0000 & 0.0108 & 0.0108 & & \\
\hline Ustd & 200 & SO4 (wt \%) & 0.1498 & 0.1498 & 0.0000 & 0.1498 & 0.1498 & & \\
\hline
\end{tabular}


Table D4. Average Measured and Bias-Corrected Chemical Compositions Versus Targeted Compositions by Oxide by Study Glass (continued)

(100-Batch 1; $200-U$ std)

\begin{tabular}{||c|c|c|c|c|c|c|c|c|c||}
\hline Glass ID & Glass \# & Oxide & $\begin{array}{c}\text { Measured } \\
\mathbf{( w t \% )}\end{array}$ & $\begin{array}{c}\text { Measured } \\
\text { Bias-Corrected } \\
\mathbf{( w t \% )}\end{array}$ & $\begin{array}{c}\text { Targeted } \\
\mathbf{( w t \% )}\end{array}$ & $\begin{array}{c}\text { Diff of } \\
\text { Measured }\end{array}$ & $\begin{array}{c}\text { Diff of } \\
\text { Meas BC }\end{array}$ & $\begin{array}{c}\text { \% Diff of } \\
\text { Measured }\end{array}$ & $\begin{array}{c}\text { \% Diff of } \\
\text { Meas BC }\end{array}$ \\
\hline Ustd & 200 & $\mathrm{SiO} 2(\mathrm{wt} \%)$ & 43.4991 & 43.8591 & 45.3530 & -1.8539 & -1.4939 & $-4.1 \%$ & $-3.3 \%$ \\
\hline Ustd & 200 & $\mathrm{ThO} 2(\mathrm{wt} \%)$ & 0.0550 & 0.0550 & 0.0000 & 0.0550 & 0.0550 & & \\
\hline Ustd & 200 & $\mathrm{TiO}(\mathrm{wt} \%)$ & 0.9227 & 0.9549 & 1.0490 & -0.1263 & -0.0941 & $-12.0 \%$ & $-9.0 \%$ \\
\hline Ustd & 200 & $\mathrm{U} 3 \mathrm{O} 8(\mathrm{wt} \%)$ & 2.2464 & 2.4060 & 2.4060 & -0.1596 & 0.0000 & $-6.6 \%$ & $0.0 \%$ \\
\hline Ustd & 200 & $\mathrm{ZnO}(\mathrm{wt} \%)$ & 0.0062 & 0.0062 & 0.0000 & 0.0062 & 0.0062 & & \\
\hline Ustd & 200 & $\mathrm{ZrO}(\mathrm{wt} \%)$ & 0.0068 & 0.0068 & 0.0000 & 0.0068 & 0.0068 & & \\
\hline Ustd & 200 & $\mathrm{Sum}(\mathrm{wt} \%)$ & 98.3477 & 97.9979 & 99.6870 & -1.3393 & -1.6891 & $-1.3 \%$ & $-1.7 \%$ \\
\hline
\end{tabular}




\section{Exhibit D1. Oxide Measurements in Analytical Sequence for} Samples Prepared Using the LM Method

BaO (wt \%) By Analytical Sequence

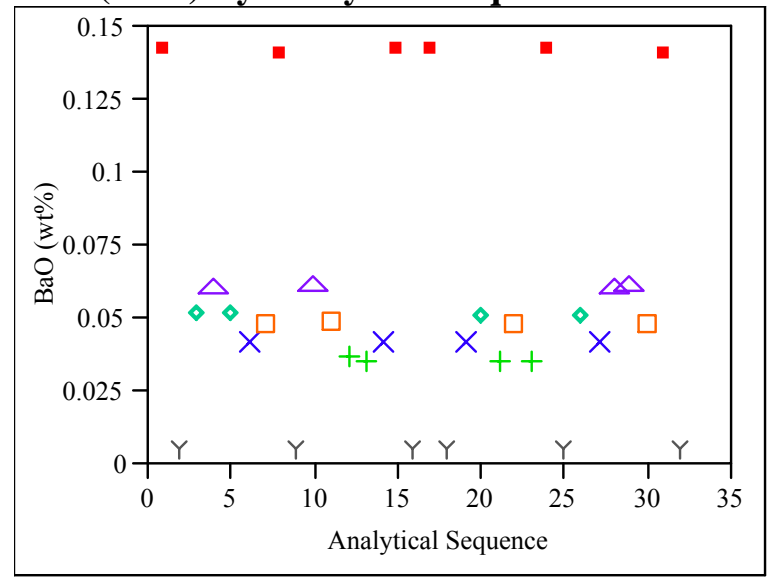

\section{CaO (wt\%) By Analytical Sequence}

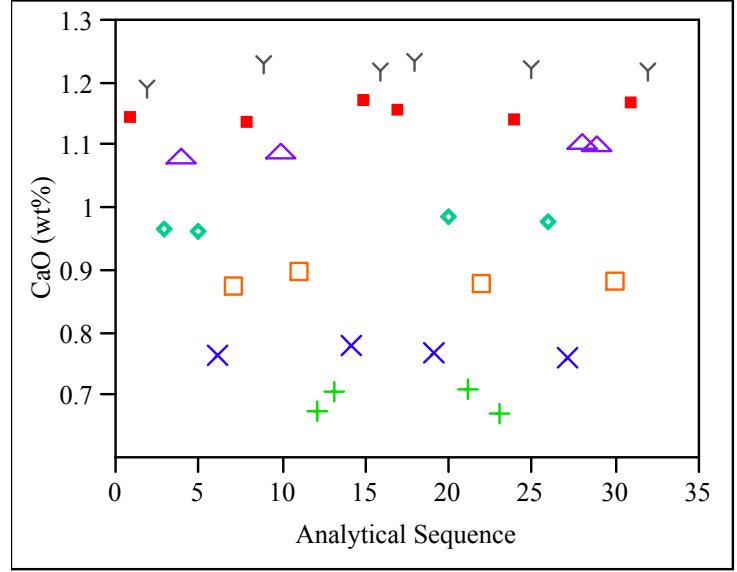

Ce2O3 (wt \%) By Analytical Sequence

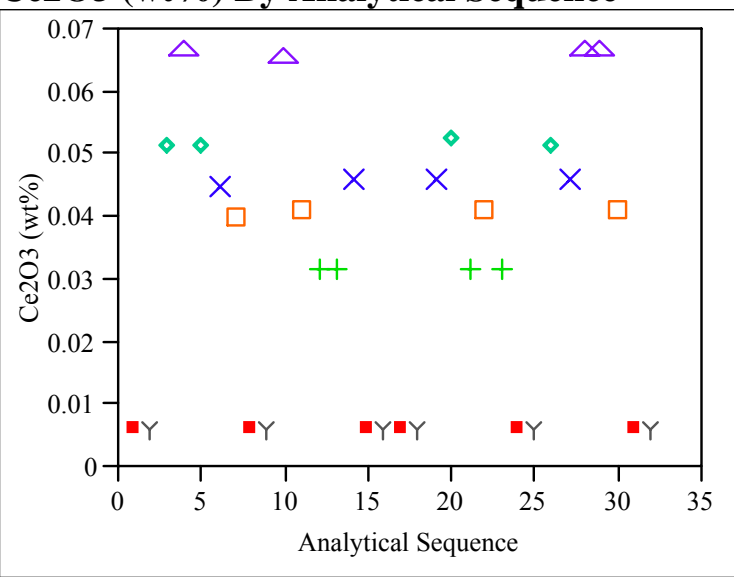

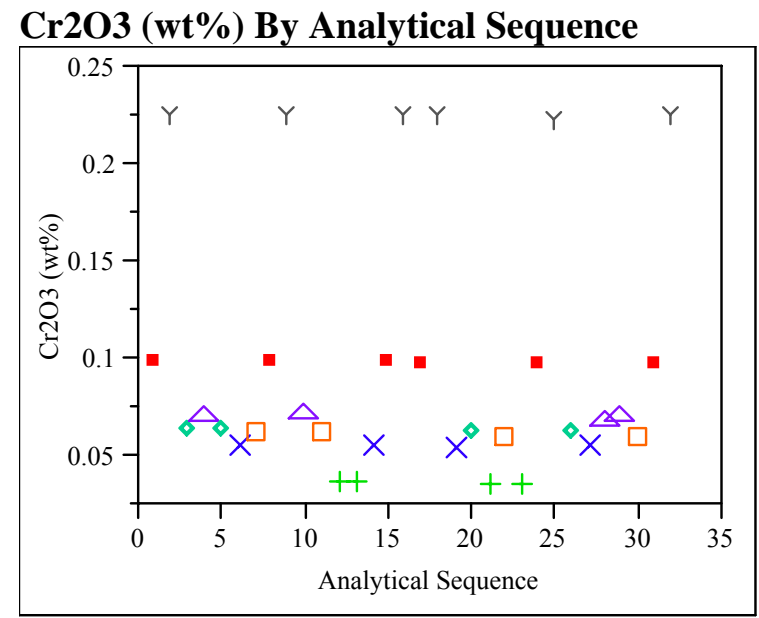

$\mathrm{CuO}$ (wt\%) By Analytical Sequence

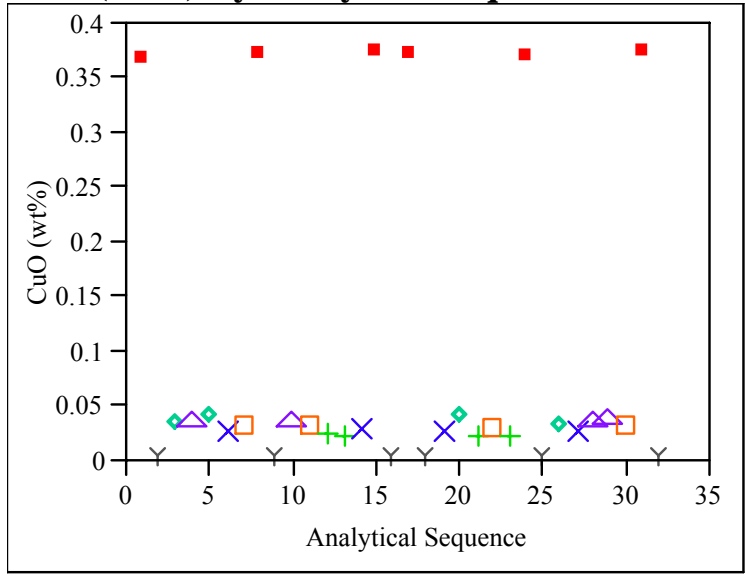

K2O (wt\%) By Analytical Sequence

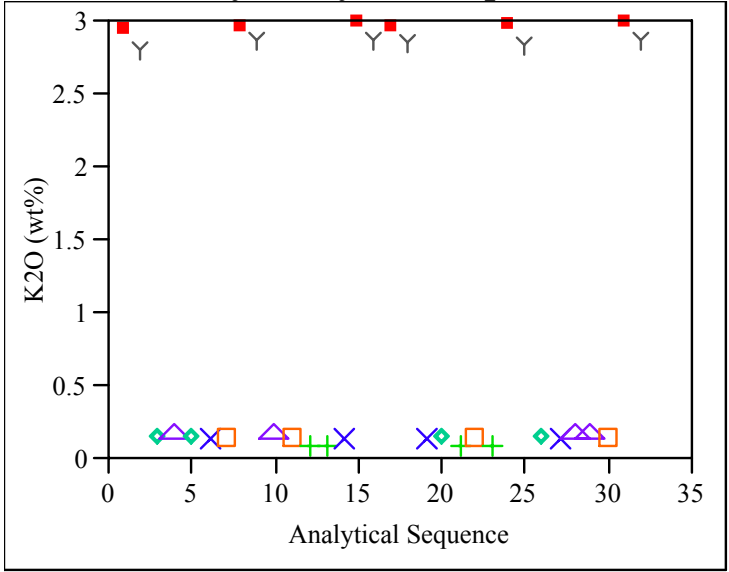




\section{Exhibit D1. Oxide Measurements in Analytical Sequence for Samples Prepared Using the LM Method (continued)}

La2O3 (wt\%) By Analytical Sequence

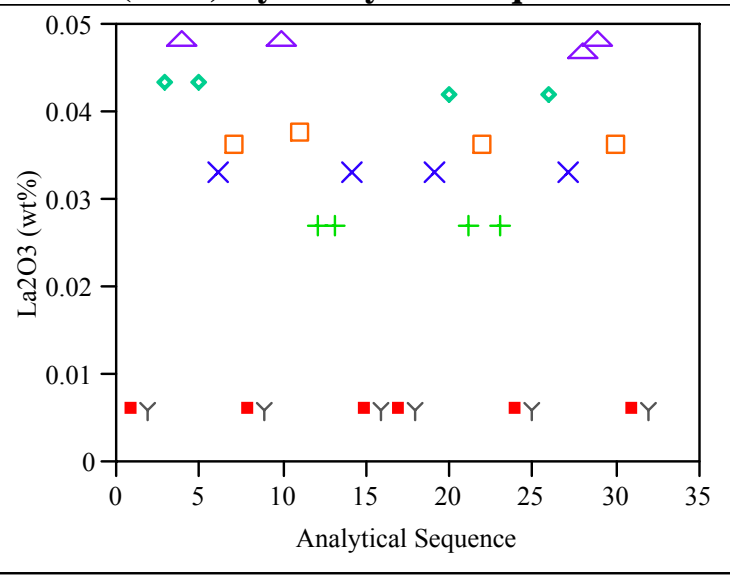

MgO (wt \%) By Analytical Sequence

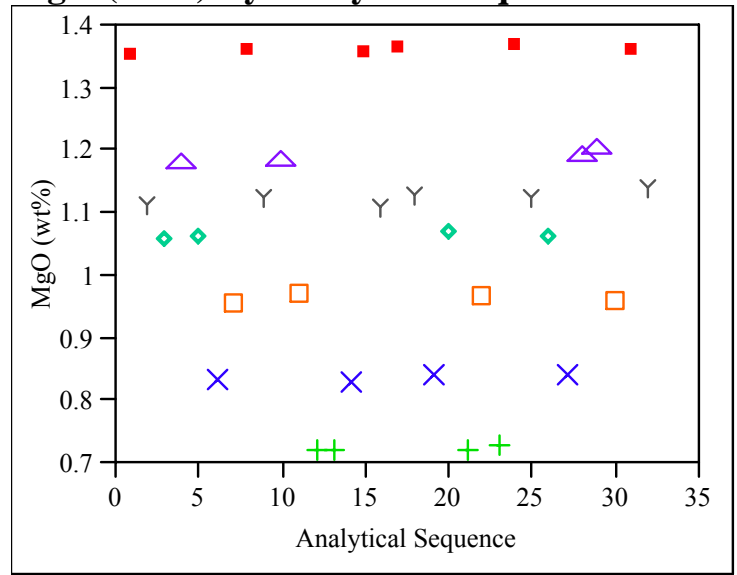

\section{MnO (wt\%) By Analytical Sequence}

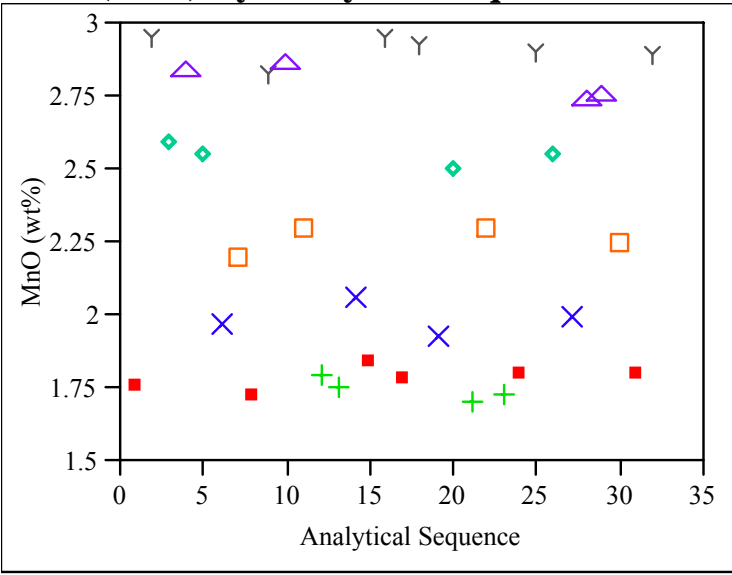

Na2O (wt\%) By Analytical Sequence

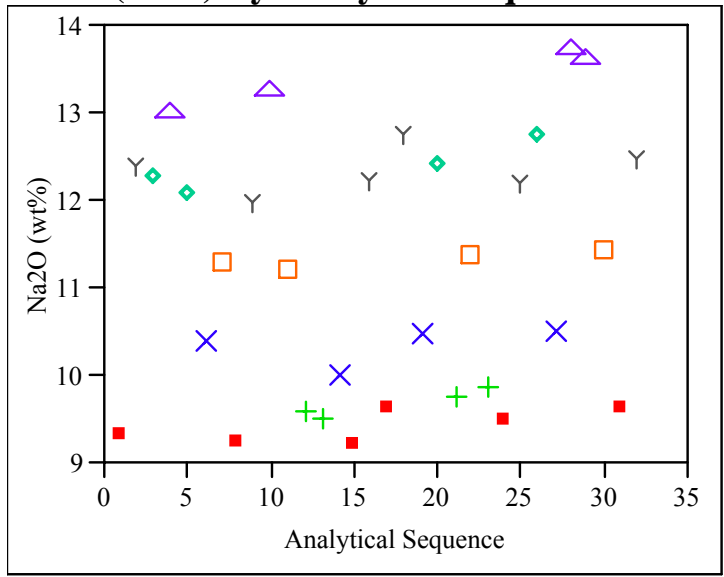

PbO (wt\%) By Analytical Sequence

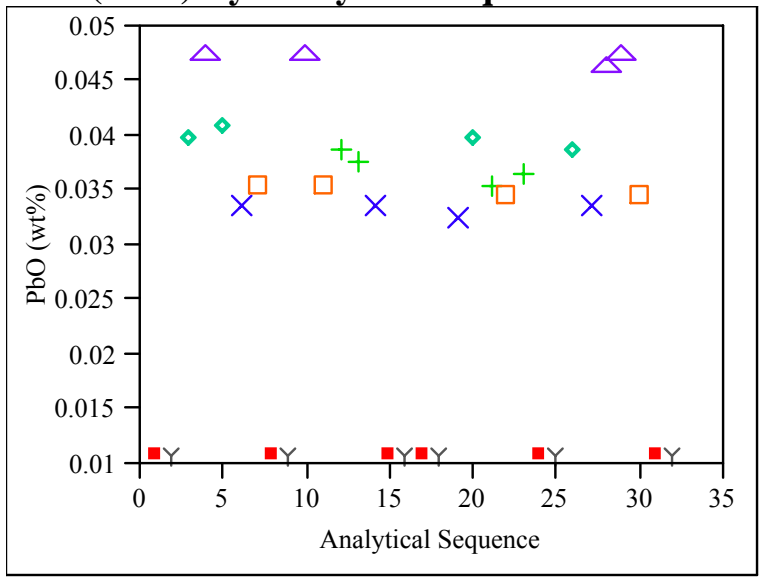

SO4 (wt\%) By Analytical Sequence

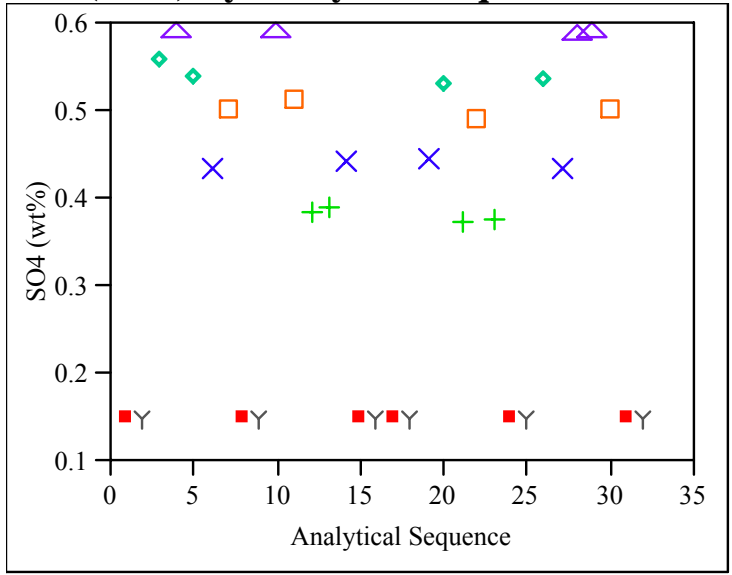




\section{Exhibit D1. Oxide Measurements in Analytical Sequence for Samples Prepared Using the LM Method (continued)}

ThO2 (wt\%) By Analytical Sequence

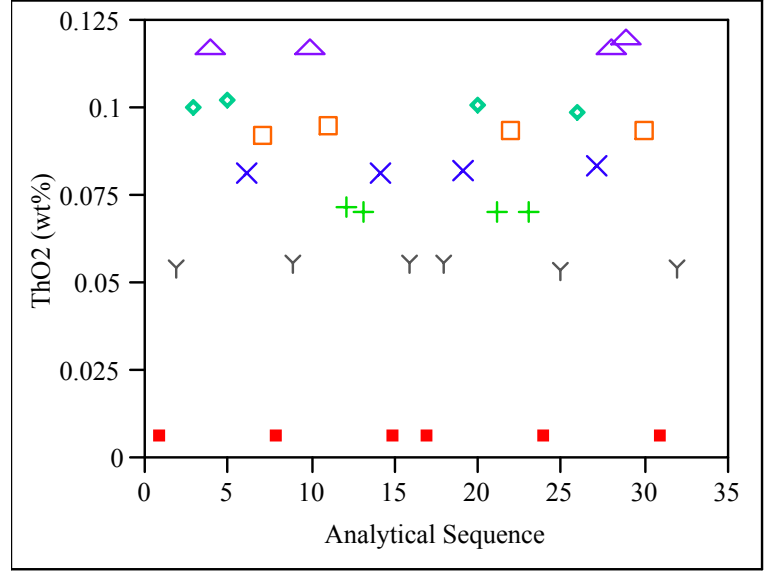

TiO2 (wt\%) By Analytical Sequence

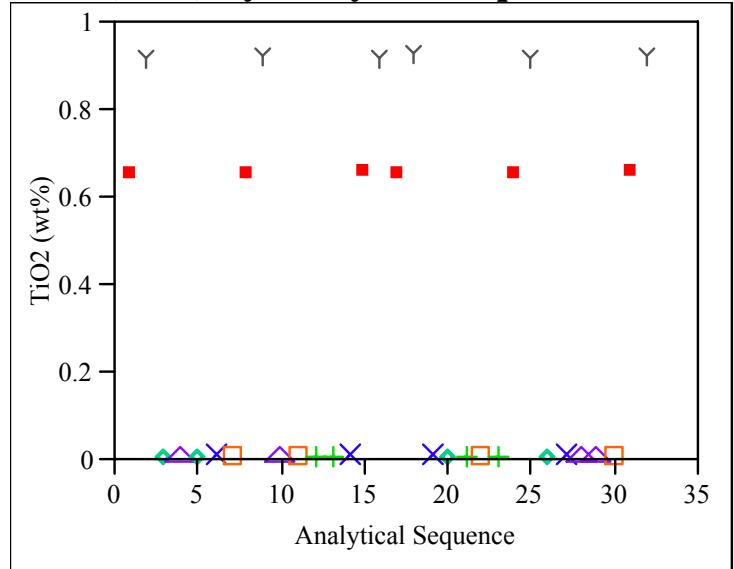

\section{ZnO (wt\%) By Analytical Sequence}

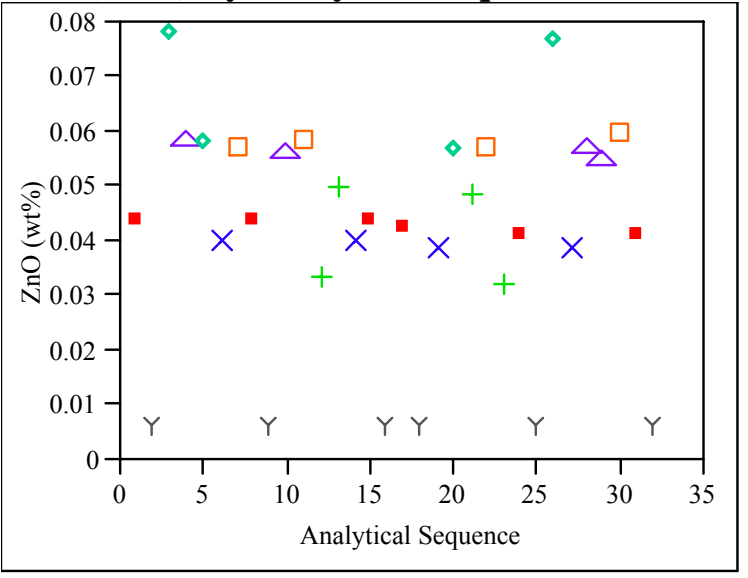

ZrO2 (wt\%) By Analytical Sequence

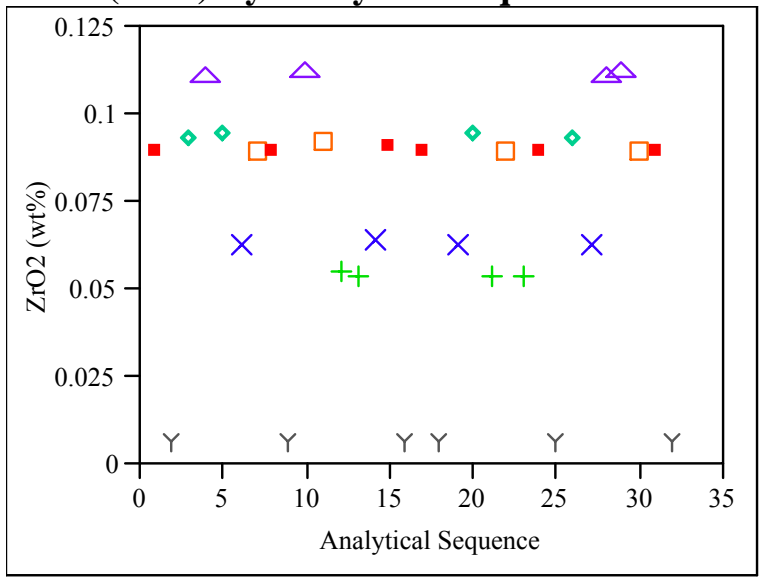




\section{Exhibit D2. Oxide Measurements in Analytical Sequence for Samples Prepared Using the PF Method}

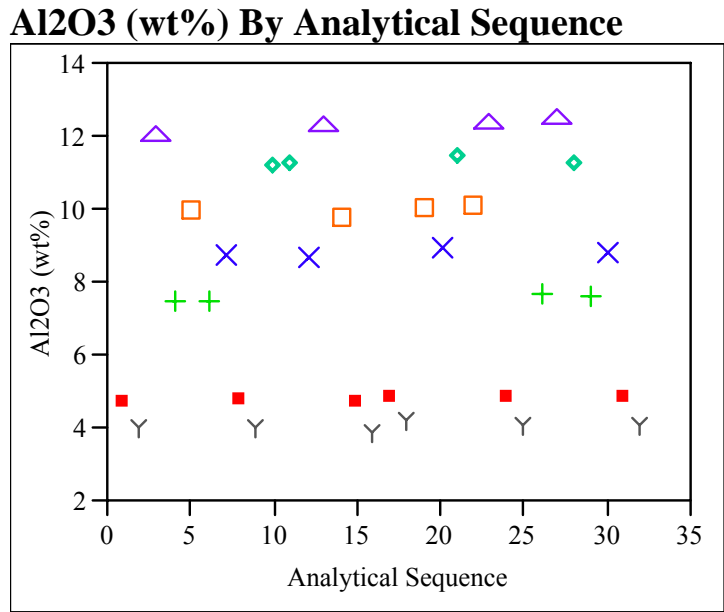

\section{B2O3 (wt\%) By Analytical Sequence}

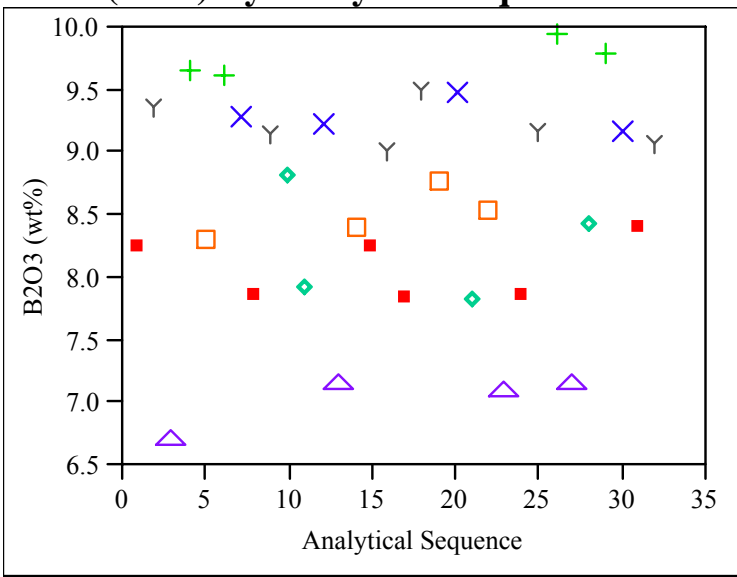

Fe2O3 (wt\%) By Analytical Sequence

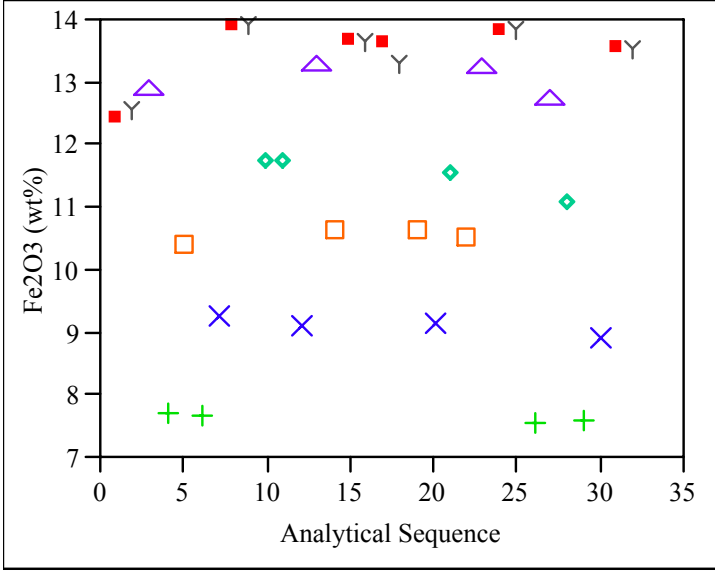

Li2O (wt\%) By Analytical Sequence

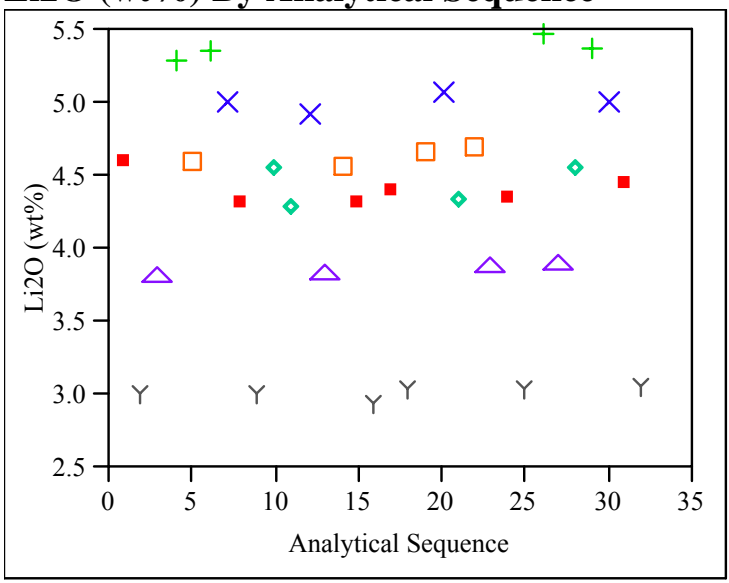

$\mathrm{NiO}$ (wt\%) By Analytical Sequence

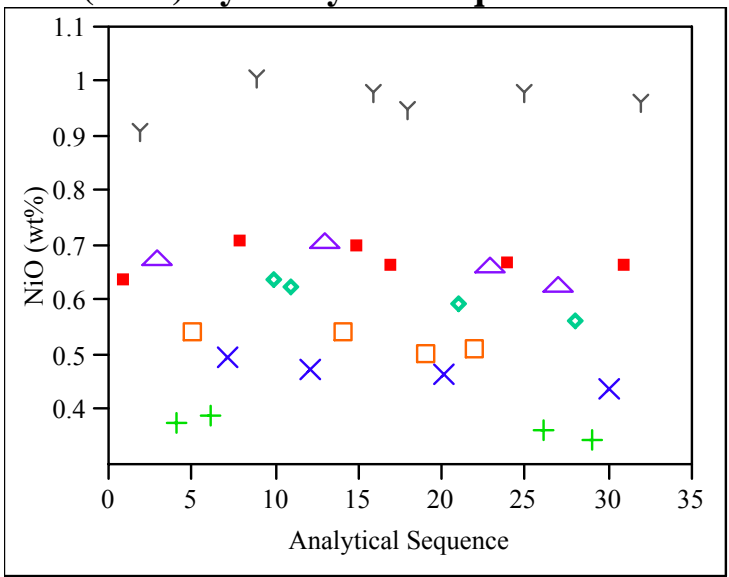

SiO2 (wt\%) By Analytical Sequence

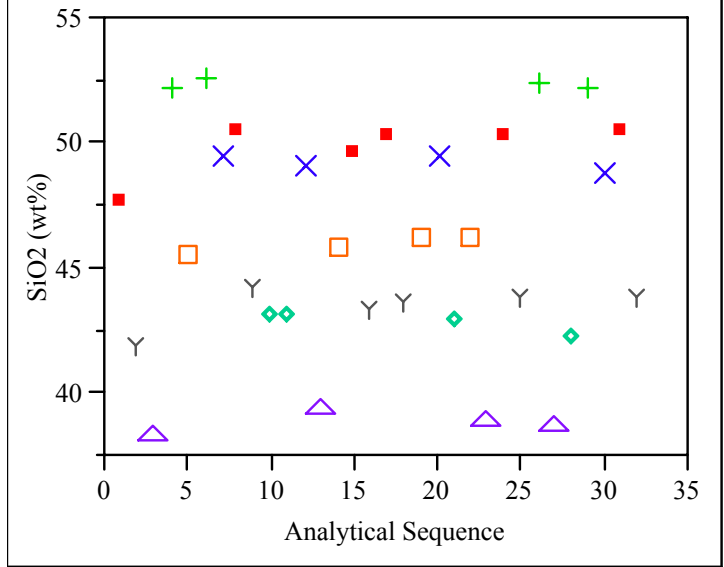


Exhibit D2. Oxide Measurements in Analytical Sequence for Samples Prepared Using the PF Method (continued)

U308 (wt\%) By Analytical Sequence

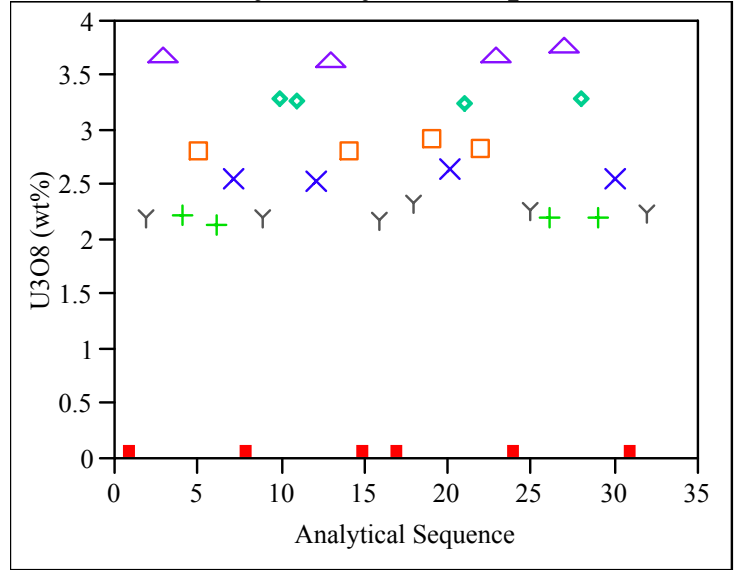




\section{Exhibit D3. PSAL Measurements by Analytical Block for Samples of the Standard Glasses Prepared Using the LM Method}

Glass ID=Batch 1

Oneway Analysis of BaO (wt\%) By Block

Reference Value $=0.151$ (wt

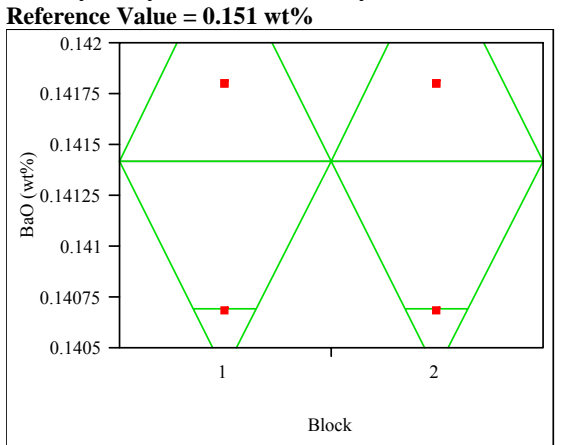

Oneway Anova

Summary of Fit

Rsquare

Adj Rsquare $\quad 00$

Root Mean Square Error $\quad 0.000645$

Mean of Response

0.141423

Observations (or Sum Wgts)

t Test

Assuming equal variances

Difference $\quad 0.00000$ t Ratio

Std Err Dif 0.00053 DF

Upper CL Dif 0.00146 Prob $>|t| 1.0000$

Upper CL Dif 0.00146 Prob $>|t| 1.0000$

Confidence

Analysis of Variance

Analysis of Variance
Source DF Sum of Squares Mean Square F Ratio Prob $>$ F $\begin{array}{lrrrrr}\text { Source } & \text { DF } & \text { Sum of Squares Mean Square } & & \\ \text { Block Ratio Prob } & 1 & 0 & 0 & 0.0000 & 1.0000\end{array}$

$\begin{array}{lrrr}\text { Block } & 1 & 0 & 0 \\ \text { Error } & 4 & 0.00000166 & 4.1552 \mathrm{e}-7 \\ \text { C. Total } & 5 & 0.00000166 & \end{array}$

Means for Oneway Anova

Level Number Mean Std Error Lower 95\% Upper 95\% $\begin{array}{llllll}1 & 3 & 0.141423 & 0.00037 & 0.14039 & 0.14246\end{array}$

$\begin{array}{lll}0.141423 & 0.00037 & 0.14039\end{array}$

0.14246
Glass ID=Batch 1

Oneway Analysis of $\mathrm{CaO}$ (wt\%) By Block

Reference Value $=1.220 \mathrm{wt} \%$

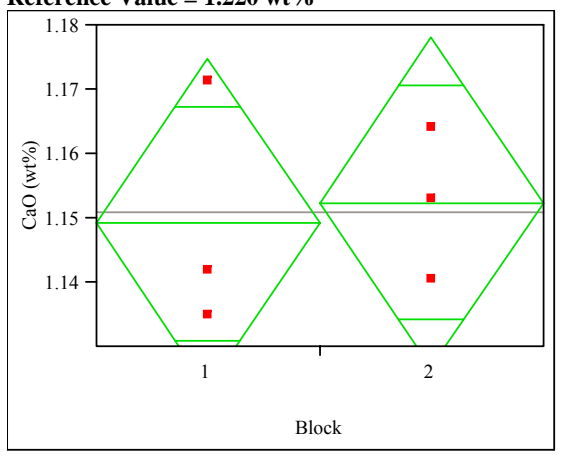

Oneway Anova

\section{Rsquare $\quad 0.015308$}

Adj Rsquare

0.015308
-0.23087

Root Mean Square Error $\quad 0.016035$

Mean of Response $\quad 1.150842$

Observations (or Sum Wgts)

t Tes

Assuming equal variances

Difference $\quad-0.00326$ t Ratio $\quad-0.24936$

$\begin{array}{lrr}\text { Std Err Dif } & 0.01309 \text { DF } & 4 \\ \text { Upper CL Dif } & 0.03309 \text { Prob }>|t| & 0.8154\end{array}$

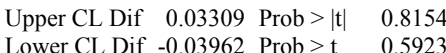

$\begin{array}{lrl}\text { Confidence } & 0.95 \text { Prob }<\mathrm{t} \quad 0.4077\end{array}$

Analysis of Variance

Source DF Sum of Squares Mean Square F Ratio Prob $>$ F $\begin{array}{llllll}\text { Block } & 1 & 0.00001599 & 0.000016 & 0.0622 & 0.8154\end{array}$ $\begin{array}{llll}\text { Error } & 4 & 0.00102848 & 0.000257\end{array}$

$\begin{array}{lll}\text { C. Total } 5 & 0.00104447\end{array}$

Means for Oneway Anova

$\begin{array}{rrrrr}3 & 1.14921 & 0.00926 & 1.1235 & 1.1749\end{array}$

$\begin{array}{llllll}1 & 3 & 1.14921 & 0.00926 & 1.1235 & 1.1749 \\ 2 & 3 & 1.15247 & 0.00926 & 1.1268 & 1.1782\end{array}$
Glass ID=Batch 1

Oneway Analysis of Ce2O3 (wt\%) By Block

Reference Value $=0 \mathrm{wt} \%$

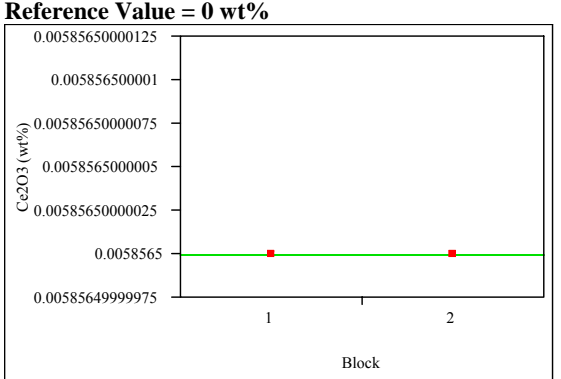

\section{Oneway Anova}

Summary of Fit

Rsquare

Adj Rsquare

Root Mean Square Error

Mean of Response

t Tes

Assuming equal variances

Difference $\quad 0$ t Ratio

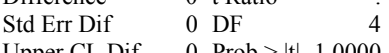

$\begin{array}{llll}\text { Upper CL Dif } & 0 & \text { Prob }>|t| & 1.0000 \\ \text { Lower CL Dif } & 0 & \text { Prob }>t & 0.5000\end{array}$

Confidence 0.95 Prob $<\mathrm{t} \quad 0.5000$

\section{Analysis of Variance}

Source DF Sum of Squares Mean Square F Ratio Prob $>$ F

$\begin{array}{llll}\text { Block } & 1 & 0 & 0 \\ \text { Error } & 4 & 0 & 0\end{array}$

C. Total 5

Means for Oneway Anova

Level Number Mean Std Error Lower 95\% Upper 95\% $\begin{array}{llllll}1 & 3 & 0.005857 & 0 & 0.00586 & 0.00586 \\ 2 & 3 & 0.005857 & 0 & 0.00586 & 0.00586\end{array}$

Std Error uses a pooled estimate of error variance 


\section{Exhibit D3. PSAL Measurements by Analytical Block for Samples of the Standard Glasses Prepared Using the LM Method (continued)}

Glass ID=Batch 1

Oneway Analysis of Cr2O3 (wt\%) By Block

Reference Value $=0.107 \mathrm{wt} \%$

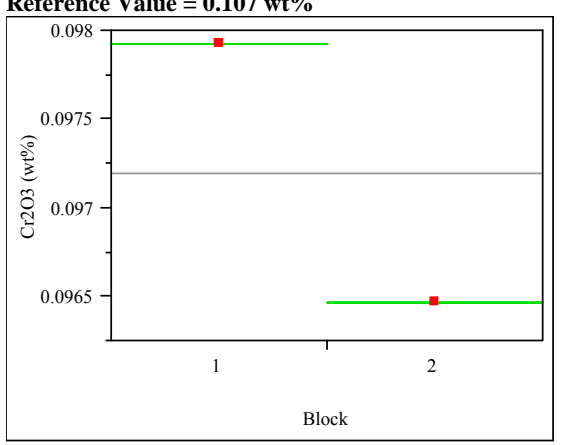

Oneway Anova

Rsquare

Adj Rsquare

Root Mean Square Erro

Mean of Response

Observations (or Sum Wgts) $\quad 6$

t Test

$1-2$

Assuming equal variances

Difference $\quad 0.001462$ t Ratio

Std Err Dif 0.000000 DF

Upper CL Dif 0.001462 Prob $>|t|$

Lower CL Dif 0.001462 Prob $>t$

Confidence $\quad 0.95$ Prob $<$ t

Analysis of Variance

Source DF Sum of Squares Mean Square F Ratio Prob > $\begin{array}{llll}\text { Block } & 1 & 0.0000032 & 0.0000032\end{array}$

$\begin{array}{lll}\text { Error } & 4 & 0\end{array}$

C. Total $5 \quad 0.0000032$

Means for Oneway Anova

Level Number Mean Std Error Lower 95\% Upper 95\%

$\begin{array}{lllllll}1 & 3 & 0.097927 & 0 & 0.09793 & 0.09793\end{array}$

$\begin{array}{llllll}2 & 3 & 0.096466 & 0 & 0.097947 & 0.0993\end{array}$

Std Error uses a pooled estimate of error variance
Glass ID=Batch 1

Oneway Analysis of $\mathrm{CuO}(\mathrm{wt} \%)$ By Block

Reference Value $=0.399 \mathrm{wt} \%$

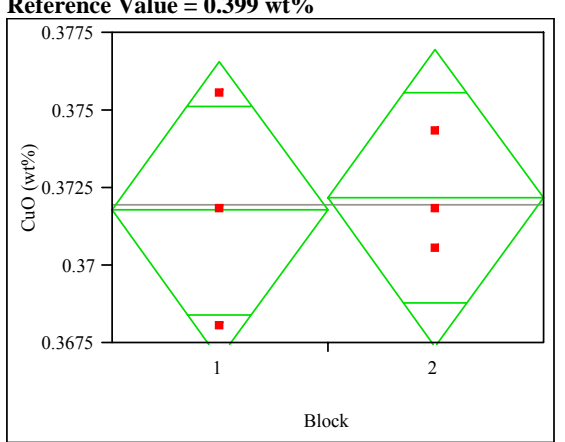

Oneway Anova

Summary of Fit

Rsquare

Adj Rsquare

0.007299

Root Mean Squa

-0.24088
0.00298
0.371993

Mean of Response 0.371993

Thest

$1-2$

Assuming equal variances

Difference $\quad-0.00042$ t Ratio $\quad-0.1715$

Std Err Dif $0.00243 \mathrm{DF} \quad-0.1715$

Upper CL Dif 0.00634 Prob $>|t| \quad 0.872$

Lower CL Dif -0.00717 Prob $>t \quad 0.5639$

$\begin{array}{lll}\text { Confidence } & 0.95 \text { Prob }<\mathrm{t} \quad 0.4361\end{array}$

\section{Analysis of Variance}

Source DF Sum of Squares Mean Square F Ratio Prob $>$ F $\begin{array}{llllll}\text { Block } & 1 & 0.00000026 & 2.6117 \mathrm{e}-7 & 0.0294 & 0.8722\end{array}$ $\begin{array}{llll}\text { Error } & 4 & 0.00003552 & 0.0000089\end{array}$

$\begin{array}{lll}\text { C. Total } & 5 & 0.00003578\end{array}$

Means for Oneway Anova

Level Number Mean Std Error Lower 95\% Upper 95\% $\begin{array}{llllll}1 & 3 & 0.371785 & 0.00172 & 0.36701 & 0.37656\end{array}$ $\begin{array}{llllll}2 & 3 & 0.372202 & 0.00172 & 0.3674 & 0.37656 \\ 2 & & 0.36743 & 0.37698\end{array}$ Std Error uses a pooled estimate of error variance
Glass ID=Batch 1

Oneway Analysis of K2O (wt\%) By Block

Reference Value $=3.327 \mathrm{wt} \%$

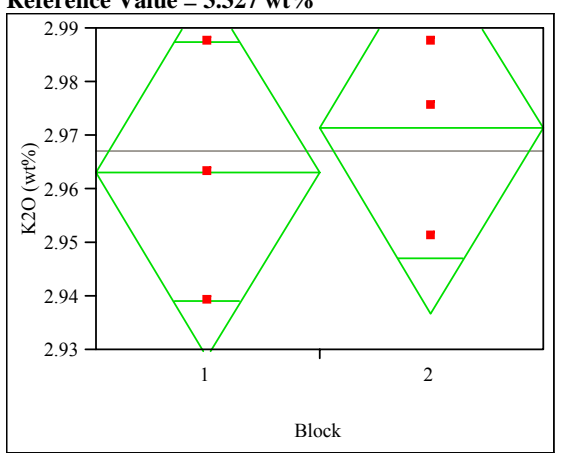

Oneway Anova

Summary of Fit

Rsquare

$\begin{array}{lr} & 0.05 \\ \text { Adj Rsquare } & -0.1875\end{array}$

Root Mean Square Error $\quad 0.021436$

Mean of Response 2.967331

Observations (or Sum Wgts)

t Tes

Assuming equal variances

Difference $\quad-0.00803$ t Ratio $\quad-0.45883$

Std Err Dif $\quad 0.01750$ D

Upper CL Dif 0.04056 Prob $>|t| 0.6702$

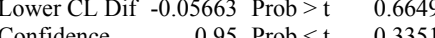

Analysis of Variance

Source DF Sum of Squares Mean Square F Ratio Prob $>$ F

$\begin{array}{lllllll}\text { Block } & 1 & 0.00009674 & 0.000097 & 0.2105 & 0.6702\end{array}$

$\begin{array}{llll}\text { Error } & 4 & 0.00183801 & 0.000460\end{array}$

C. Total 50.0019347

Level Nur Oneway Anova

$\begin{array}{lrrrrr}\text { Level Number } & \text { Mean } & \text { Std Error } & \text { Lower 95\% } & \text { Upper 95\% } \\ 1 & 3 & 2.96332 & 0.01238 & 2.9290 & 2.9977\end{array}$

Std Error uses a pooled estimate of error variance 


\section{Exhibit D3. PSAL Measurements by Analytical Block for Samples of the Standard Glasses Prepared Using the LM Method (continued)}

Glass ID=Batch 1

Oneway Analysis of La2O3 (wt \%) By Block Reference Value $=0 \mathrm{wt} \%$

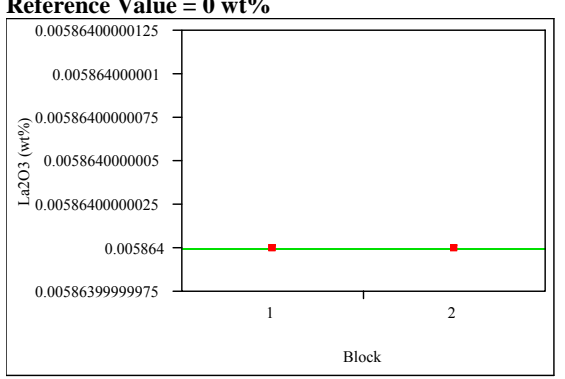

Oneway Anova

Oneway Anova
Summary of Fit

Rsquare

Root Mean Square Error

Met of

0.005864

(or Sum Wgts)

Test

Assuming equal variances

$\begin{array}{lllr}\text { Difference } & 0 & \text { t Ratio } & \\ \text { Std Err Dif } & 0 & \text { DF } & 4 \\ \text { Upper CL Dif } & 0 & \text { Prob }>|t| & 1.0000 \\ \text { Lower CL Dif } & 0 & \text { Prob }>t & 0.5000 \\ \text { Confidence } & 0.95 & \text { Prob }<t & 0.5000\end{array}$

$\begin{aligned} 0 & \text { Prob }>t \quad 0.5000\end{aligned}$

Analysis of Variance

Source DF Sum of Squares Mean Square F Ratio Prob $>$ F $\begin{array}{llll}\text { Block } & 1 & 0 & 0\end{array}$

Error 4 Total 5 - 5

Means for Oneway Anova

Means for Oneway Anova

$\begin{array}{rrrrrr} & \text { Level Number } & \text { Mean } & \text { Std Error Lower 95\% } & \text { Upper 95\% } \\ 1 & 3 & 0.005864 & 0 & 0.00586 & 0.00586\end{array}$

$\begin{array}{llrrrr}1 & 3 & 0.005864 & 0 & 0.00586 & 0.00586 \\ 2 & 3 & 0.005864 & 0 & 0.00586 & 0.00586\end{array}$

Std Error uses a pooled estimate of error variance
Glass ID=Batch 1

Oneway Anlysis of $\mathrm{MgO}$ (wt\%) By Block

Reference Value $=1.419 \mathrm{wt} \%$

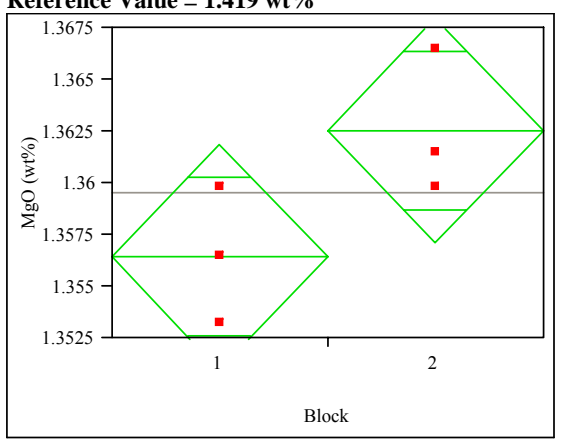

Oneway Anova

Summary of Fit

$\begin{array}{ll}\text { Adj Rsquare } & 0.547511 \\ 0.434389\end{array}$

Root Mean Square Error $\quad 0.003385$

Mean of Response $\quad 1.35953$

Observations (or Sum Wgts)

t Test

$1-2$

Assuming equal variances

Difference $\quad-0.00608$ t Ratio $\quad-2.2$

Std Err Dif 0.00276 DF

Upper CL Dif 0.00159 Prob $>|t| 0.0927$

Lower CL Dif -0.01375 Prob $>t \quad 0.9537$

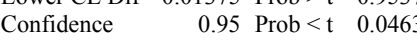

Analysis of Variance

Source DF Sum of Squares Mean Square F Ratio Prob $>$ F

$\begin{array}{llllll}\text { Block } & 1 & 0.00005546 & 0.000055 & 4.8400 & 0.0927\end{array}$

$\begin{array}{lll}\text { Error } & 4 & 0.00004583 \\ \text { C. Totat } & 5 & 0.0010129\end{array}$ 0.00001

C. Total $5 \quad 0.00010129$

Means for Oneway Anova

Level Number Mean Std Error Lower 95\% Upper 95\%

$\begin{array}{lllll}3 & 1.35649 & 0.00195 & 1.3511 & 1.3619\end{array}$

$\begin{array}{llllll}2 & 3 & 1.36257 & 0.00195 & 1.3571 & 1.3680\end{array}$

Std Error uses a pooled estimate of error variance
Glass ID=Batch 1

Oneway Anlysis of $\mathrm{MnO}$ (wt\%) By Block

Reference Value $=1.726 \mathrm{wt} \%$

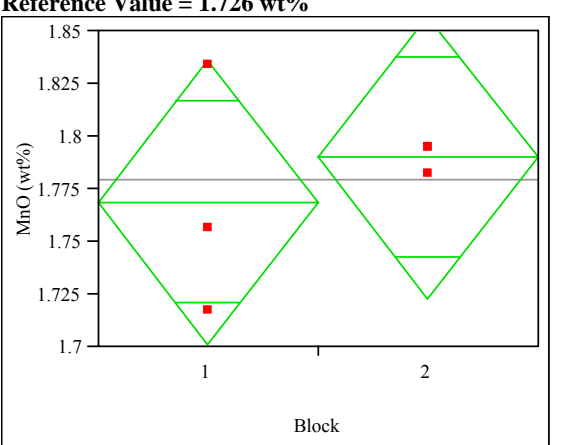

\section{Oneway Anova}

Summary of Fit

Rsquare

0.088968
-0.13879

Adj Rsquare

Root Mean Square Error $\quad 0.04217$

Mean of Response $\quad 1.779704$

Observations (or Sum Wgts)

t Test

Assuming equal variances

Difference $\quad-0.02152$ t Ratio $\quad-0.625$

Std Err Dif 0.03443 DF $\quad 4$

Upper CL Dif 0.07408 Prob $>|t| 0.5659$

Lower CL Dif -0.11712 Prob $>t \quad 0.7171$

Confidence $\quad 0.95$ Prob $<\mathrm{t} \quad 0.2829$

Analysis of Variance

Source DF Sum of Squares Mean Square F Ratio Prob $>$ F $\begin{array}{lllllll}\text { Block } & 1 & 0.00069467 & 0.000695 & 0.3906 & 0.5659\end{array}$ $\begin{array}{llll}\text { Error } & 4 & 0.00711338 & 0.001778\end{array}$

C. Total $5 \quad 0.00780804$

Means for Oneway Anova $\begin{array}{rrrrr}3 & 1.76894 & 0.02435 & 1.7013 & 1.8365\end{array}$ $\begin{array}{llllll}1 & 3 & 1.76894 & 0.02435 & 1.7013 & 1.8365 \\ 2 & 3 & 1.79046 & 0.02435 & 1.7229 & 1.858\end{array}$ Std Error uses a pooled estimate of error variance 


\section{Exhibit D3. PSAL Measurements by Analytical Block for Samples of the Standard Glasses Prepared Using the LM Method (continued)}

\section{Glass ID=Batch 1}

Oneway Analysis of Na2O (wt\%) By Block

Reference Value $=9.003 \mathrm{wt} \%$

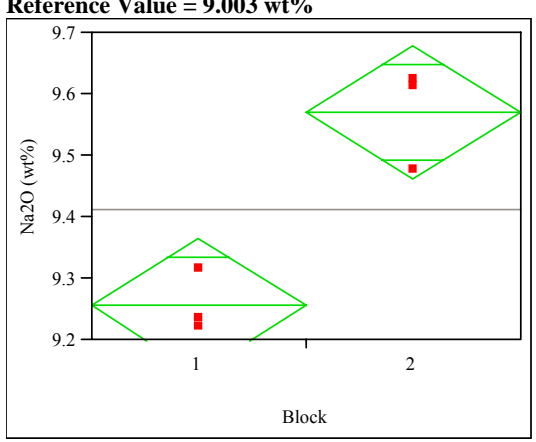

Oneway Anova

Summary of Fit

Rsquare

Adj Rsquare

Mean of Response 9.413533

t Test

$1-2$

Assuming equal variances

Difference $\quad-0.31453$ t Ratio $\quad-5.64076$ Std Err Dif 0.05576 DF

Upper CL Dif -0.15972 Prob $>|t| 0.0049$

Lower CL Dif -0.46935 Prob $>t \quad 0.9976$

Confidence 0.95 Prob $<\mathrm{t} \quad 0.0024$

Analysis of Variance

Source DF Sum of Squares Mean Square F Ratio Prob $>$ F $\begin{array}{llllll}\text { Block } & 1 & 0.14839683 & 0.148397 & 31.8182 & 0.0049\end{array}$ $\begin{array}{llll}\text { Error } & 4 & 0.01865560 & 0.004664\end{array}$

C. Total $5 \quad 0.1670524$

Means for Oneway Anova

Level Number Mean Std Error Lower 95\% Upper 95\%

$\begin{array}{llllll}1 & 3 & 9.25627 & 0.03943 & 9.1468 & 9.3657\end{array}$

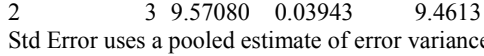

Glass ID=Batch 1

Oneway Analysis of PbO (wt\%) By Block

Reference Value $=0 \mathrm{wt} \%$

0.01077200000125

0.010772000001

总 0.01077200000075

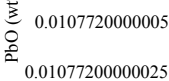

0.01077199999975

0.010772

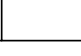

Oneway Anova

ummary of Fit

Rsquare

Adj Rsquare

Root Mean Square Erro

Mean of Response

Observations (or Sum Wgts)

Test

Assuming equal variances

$\begin{array}{lrl}\text { Difference } & 0 \mathrm{t} \text { Ratio } & 0 \\ \text { Std Err Dif } & 1.735 \mathrm{e}-18 \mathrm{DF} & 4\end{array}$

$\begin{array}{lrlr}\text { Std Err Dif } & 1.735 \mathrm{e}-18 & \mathrm{DF} & 4 \\ \text { Upper CL Dif } & 4.816 \mathrm{e}-18 & \text { Prob }>|t| & 1.0000\end{array}$

$\begin{array}{rrrr}\text { Upper CL Dif } & 4.816 \mathrm{e}-18 & \text { Prob }>|t| & 1.0000 \\ \text { Lower CL Dif } & -4.82 \mathrm{e}-18 & \text { Prob }>\mathrm{t} & 0.5000\end{array}$

$\begin{array}{rrrr}\text { Lower CL Dif } & -4.82 \mathrm{e}-18 & \text { Prob }>\mathrm{t} & 0.5000 \\ \text { Confidence } & 0.95 & \text { Prob }<\mathrm{t} & 0.5000\end{array}$

Analysis of Variance

Source DF Sum of Squares Mean Square F Ratio Prob $>$ F

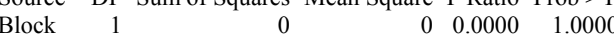
$\begin{array}{llll} & & & \end{array}$

C. Total 5 1.8056e- 35

Level Number Mean Std Error Lower 95\% Upper 95\% $\begin{array}{rrrrrr}\text { Level Number } & \text { Mean } & \text { Std Error } & \text { Lower 95\% } & \text { Upper 95\% } \\ 1 & 3 & 0.010772 & 1.227 \mathrm{e}-18 & 0.01077 & 0.01077\end{array}$ $\begin{array}{llllll}1 & 3 & 0.010772 & 1.227 \mathrm{e}-18 & 0.01077 & 0.01077 \\ 2 & 3 & 0.010772 & 1.227 \mathrm{e}-18 & 0.01077 & 0.01077\end{array}$ Std Error uses a pooled estimate of error variance
Glass ID=Batch 1

Oneway Analysis of $\mathrm{SO} 4$ (wt\%) By Block

Reference Value $=0 \mathrm{wt} \%$

0.14979500000125

0.149795000001

遥

0.14979500000075

0.14979500000025

0.14979499999975

.149795

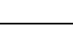

Block

Oneway Anova

ummary of Fit

Rsquare

Adj Rsquare

Root Mean Square Erro

Mean of Response

Observations (or Sum Wgts) 6

t Tes

Assuming equal variances

Difference $\quad 0$ t Ratio

Std Err Dif $\quad 0$ DF

Upper CL Dif $\quad 0$ Prob $>|t| 1.0000$

Lower CL Dif 0 Prob $>t \quad 0.5000$

Analysis of Variance

Analysis of Variance
Source DF Sum of Squares Mean Square F Ratio Prob $>$ F $\begin{array}{lrrr}\text { Source } & \text { DF } & \text { Sum of Squares } & \text { Mean Square } \\ \text { Block } & 1 & 0 & 0 \\ & 4 & 0\end{array}$

$\begin{array}{lll}\text { Error } & 4 & 0\end{array}$

Means for Oneway Anova

Means for Oneway Anova
Level Number Mean Std Error Lower 95\% Upper 95\% $\begin{array}{rrrrrr}\text { Level Number } & \text { Mean } & \text { Std Error } & \text { Lower 95\% } & \text { Upper 95\% } \\ 1 & 3 & 0.149795 & 0 & 0.14979 & 0.14979\end{array}$ $\begin{array}{lllll}3 & 0.149795 & 0 & 0.14979 & 0.14979\end{array}$ 


\section{Exhibit D3. PSAL Measurements by Analytical Block for Samples of the Standard Glasses Prepared Using the LM Method (continued)}

Glass ID=Batch 1

Oneway Analysis of ThO2 (wt\%) By Block

Reference Value $=0 \mathrm{wt} \%$

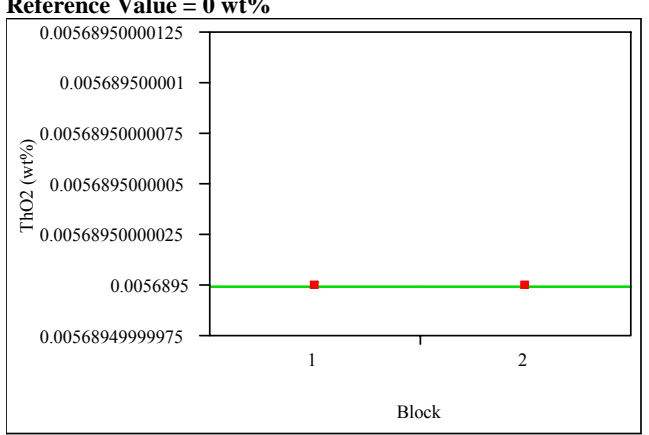

Oneway Anova

ummary of Fit

Rsquare

Adj Rsquare

Root Mean Square Erro

Mean of Response

Observations (or Sum Wgts) $\begin{array}{r}0.005689 \\ \hline\end{array}$

Test

Assuming equal variances

\section{Difference $\quad 0$ t Ratio \\ Std Err Dif 0 DF \\ Upper CL Dif 0 Prob $>|t| 1.0000$ \\ Lower CL Dif 0 Prob $>t$ t 0.5000}

Analysis of Variance

Source DF Sum of Squares Mean Square F Ratio Prob $>$ F Block 1 Sum of Squares Mean Square

Error 4

Means for Oneway Anova 0
0

Level Number Mean Std Error Lower 95\% Upper 95\%

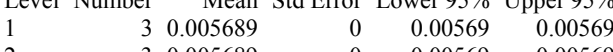

Std Error uses a pooled estimate of error variance
Glass ID=Batch 1

Oneway Analysis of TiO2 (wt\%) By Block

Reference Value $=0.677 \mathrm{wt} \%$

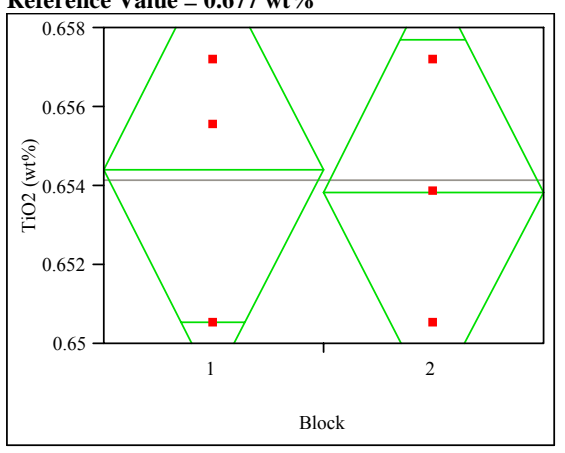

Oneway Anova

\section{Summary of Fit}

Rsquare $\quad 0.009901$

Adj Rsquare $\quad-0.23762$

Mean of Response $\quad 0.654134$

Observations (or Sum Wgts)

t Test

$1-2$

Assuming equal variances

Difference $\quad 0.00056$ t Ratio $\quad 0.2$

Std Err Dif 0.00278 DF

Upper CL Dif 0.00827 Prob $>|t| 0.8512$

Lower CL Dif -0.00716 Prob $>t \quad 0.4256$

Confidence $\quad 0.95$ Prob $<t \quad 0.5744$

Analysis of Variance

Source DF Sum of Squares Mean Square F Ratio Prob $>$ F $\begin{array}{llllll}\text { Block } & 1 & 0.00000046 & 4.637 \mathrm{e}-7 & 0.0400 & 0.8512\end{array}$ $\begin{array}{llll}\text { Error } & 4 & 0.00004637 & 0.000012\end{array}$

C. Total $5 \quad 0.00004683$

Means for Oneway Anova
Level Number Mean Std Error Lower 95\% Upper 95\%

$\begin{array}{rrrrrr}3 & 0.654412 & 0.00197 & 0.64895 & 0.65987\end{array}$

$\begin{array}{lllllll}1 & 3 & 0.654412 & 0.00197 & 0.64895 & 0.65987 \\ 2 & 3 & 0.653856 & 0.00197 & 0.64840 & 0.65931\end{array}$

Std Error uses a pooled estimate of error variance
Glass ID=Batch 1

(wt \%) By Block

Reference Value $=0 \mathrm{wt} \%$

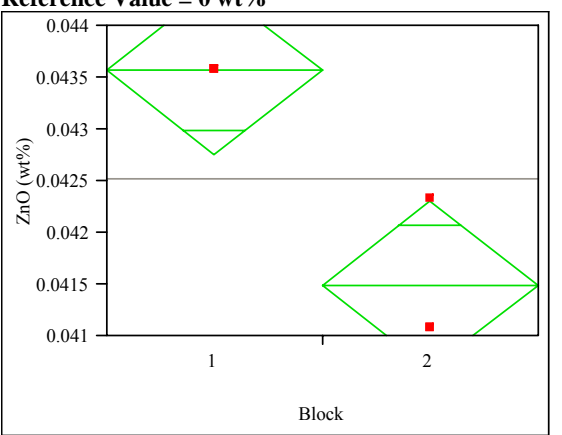

Oneway Anova

Summary of Fit

Adj Rsquare $\quad 0.827586$

Root Mean Square Error $\quad 0.000508$

$\begin{array}{lr}\text { Mean of Response } & 0.042531 \\ \text { Observations (or Sum Wgts) } & 6\end{array}$

t Test

$1-2$

Assuming equal variances

Difference 0.002075 t Ratio

$\begin{array}{llr}\text { Std Err Dif } & 0.000415 \text { DF } & 4 \\ \text { Upper CL Dif } & 0.003227 \text { Prob }>|t| & 0.0075\end{array}$

Lower CL Dif 0.000923 Prob $>t \quad 0.003$

$\begin{array}{lll}\text { Confidence } & 0.95 \text { Prob }<\mathrm{t} \quad 0.9963\end{array}$

Analysis of Variance

Source DF Sum of Squares Mean Square F Ratio Prob $>$ F

$\begin{array}{llllll}\text { Block } & 1 & 0.00000646 & 0.0000065 & 25.0000 & 0.0075\end{array}$

$\begin{array}{llll}\text { Error } & 4 & 0.00000103 & 2.5825 \mathrm{e}-7\end{array}$

C. Total 50.0000074

Means for Oneway Anova

Level Number Mean Std Error Lower 95\% Upper 95\%

$\begin{array}{llllll}1 & 3 & 0.043568 & 0.00029 & 0.04275 & 0.04438\end{array}$

$\begin{array}{llllll}2 & 3 & 0.041493 & 0.00029 & 0.04068 & 0.04231\end{array}$

Std Error uses a pooled estimate of error variance 


\section{Exhibit D3. PSAL Measurements by Analytical Block for Samples of the Standard Glasses Prepared Using the LM Method (continued)}

Glass ID=Batch 1

Oneway Analysis of ZrO2 (wt\%) By Block

Reference Value $=0.098 \mathrm{wt} \%$

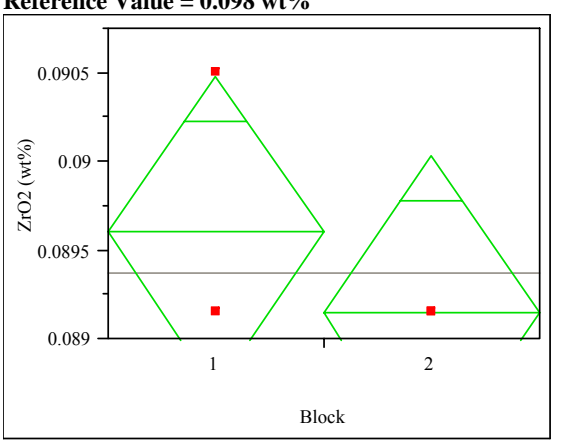

Oneway Anova

Rsquare

Adj Rsquare

$2.07 \mathrm{e}-14$

Root Mean Square Error $\quad 0.000551$

Mean of Response 0.089378

t Test

$1-2$

Assuming equal variances

Difference $\quad 0.00045$ t Ratio Std Err Dif $\quad 0.00045$ DF

Upper CL Dif 0.00170 Prob $>|t| 0.3739$

Lower CL Dif -0.00080 Prob $>t \quad 0.1870$

$\begin{array}{llll}\text { Confidence } & 0.95 \text { Prob }<\mathrm{t} \quad 0.8130\end{array}$

\section{Analysis of Variance}

Source DF Sum of Squares Mean Square F Ratio Prob $>$ F $\begin{array}{lllllll}\text { Block } & 1 & 3.0411 \mathrm{e}-7 & 3.0411 \mathrm{e}-7 & 1.0000 & 0.3739\end{array}$ $\begin{array}{llll}\text { Error } & 4 & 0.00000122 & 3.0411 \mathrm{e}-7\end{array}$

C. Total $5 \quad 0.00000152$

Means for Oneway Anova

Level Number Mean Std Error Lower 95\% Upper 95\%

$\begin{array}{llllll}1 & 3 & 0.089603 & 0.00032 & 0.08872 & 0.09049\end{array}$

$\begin{array}{llllll}2 & 3 & 0.089153 & 0.00032 & 0.08827 & 0.09004\end{array}$

Std Error uses a pooled estimate of error variance
Glass ID=Ustd

Oneway Analysis of BaO (wt\%) By Block

Reference Value $=0 \mathrm{wt} \%$

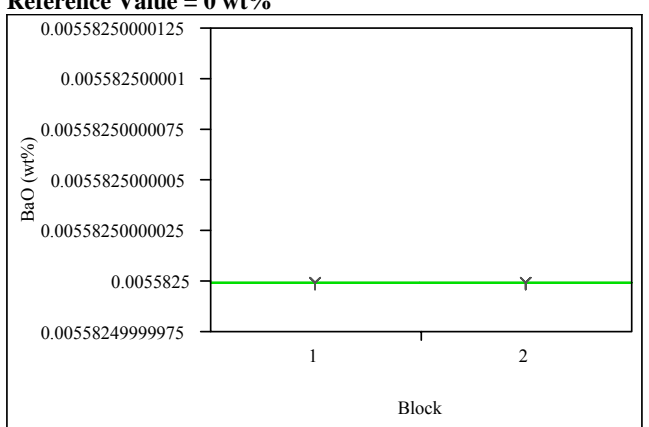

Oneway Anova

Summary of Fit

Rsquare

Adj Rsquare

Root Mean Square Erro

Mean of Respons

Observations (or Sum Wgts)

t Tes

Assuming equal variances

\section{Difference $\quad 0$ t Ratio}

$\begin{array}{llll}\text { Std Err Dif } & 0 & \text { DF } & 4\end{array}$

Upper CL Dif 0 Prob $>|t| 1.0000$

Lower CL Dif $\quad 0$ Prob $>$ t 0.5000

Analysis of Variance

Source DF Sum of Squares Mean Square F Ratio Prob $>$ F $\begin{array}{lrrr}\text { Source } & \text { DF } & \text { Sum of Squares } & \text { Mean Square } \\ \text { Block } & 1 & 0 & 0 \\ & 4 & 0\end{array}$

$\begin{array}{lll}\text { Error } & 4 & 0\end{array}$

C. Total 5
Means for Oneway Anova

Means for Oneway Anova
Level Number Mean Std Error Lower 95\% Upper 95\%

$\begin{array}{rrrrrr}\text { Level Number } & \text { Mean } & \text { Std Error } & \text { Lower 95\% } & \text { Upper 95\% } \\ 1 & 3 & 0.005583 & 0 & 0.00558 & 0.00558\end{array}$ $\begin{array}{llllll}1 & 3 & 0.005583 & 0 & 0.00558 & 0.00558 \\ 2 & 3 & 0.005583 & 0 & 0.00558 & 0.00558\end{array}$

Std Error uses a pooled estimate of error variance
Glass ID=Ustd

Oneway Analysis of CaO (wt\%) By Block

Reference Value $=1.301 \mathrm{wt} \%$

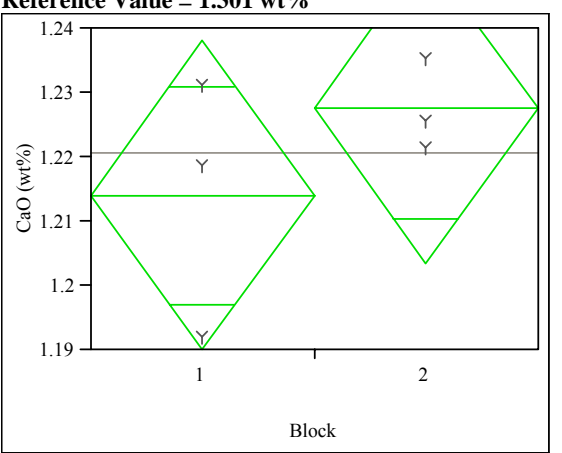

Oneway Anova

Summary of Fit

Rsquare

$\begin{array}{ll} & 0.233029 \\ \text { Adj Rsquare } & 0.041286\end{array}$

Adj Rsquare $\quad 0.041286$

Reot Mean Square Eror $\quad 0.015026$

Observations (or Sur

1.220802

Observations (or Sum Wgts)

t Test

Assuming equal variances

Difference $\quad-0.01353$ t Ratio -1.10241

$\begin{array}{lrr}\text { Std Err Dif } & 0.01227 \mathrm{DF} & 4 \\ & & \end{array}$

Upper CL Dif 0.02054 Prob $>|t| \quad 0.3321$

$\begin{array}{lrr}\text { Lower CL Dif } & -0.04759 \text { Prob }>t & 0.8339 \\ \text { Confidence } & 0.95 \text { Prob }<\mathrm{t} & 0.1661\end{array}$

Analysis of Variance

Source DF Sum of Squares Mean Square F Ratio Prob $>$ F

$\begin{array}{llllll}\text { Block } & 1 & 0.00027441 & 0.000274 & 1.2153 & 0.3321\end{array}$

$\begin{array}{llll}\text { Error } & 4 & 0.00090318 & 0.000226\end{array}$

. Total 50.0011775

Mevel Number

$\begin{array}{rrrrrr}\text { Level Number } & \text { Mean } & \text { Std Error } & \text { Lower 95\% } & \text { Upper 95\% } \\ 1 & 3 & 1.21404 & 0.00868 & 1.1900 & 1.2381\end{array}$

Std Error uses a pooled 


\section{Exhibit D3. PSAL Measurements by Analytical Block for Samples of the Standard Glasses Prepared Using the LM Method (continued)}

Glass ID=Ustd

Oneway Analysis of $\mathrm{Ce} 2 \mathrm{O} 3$ (wt\%) By Block Reference Value $=0 \mathrm{wt} \%$

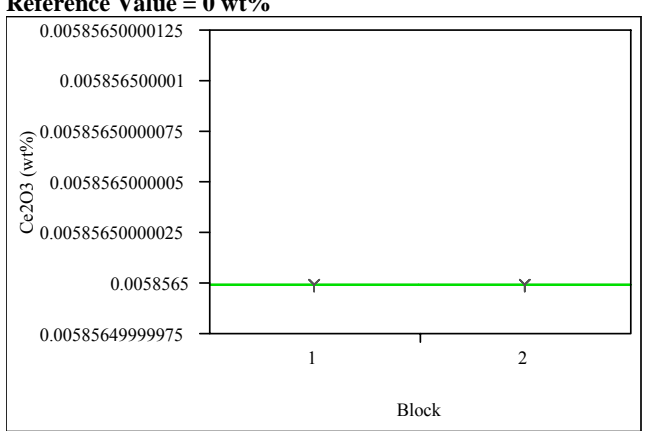

Oneway Anova

Summary of Fit

Rsquare

Adj Rsquare

Root Mean Square Erro

Mean of Respons

Observations (or Sum Wgts) $\quad 6$

t Test

Assuming equal variances

\section{Difference

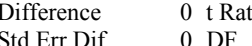 \\ Upper CL Dif 0 DF 4 \\ Lower CL Dif $\quad 0$ Prob $>$ t 0.5000 \\ Confidence 0.95 Prob $<$ t 0.5000}

Analysis of Variance

Source DF Sum of Squares Mean Square F Ratio Prob $>$ F Block $11 \quad 0 \quad 0$

$\begin{array}{ll}\text { Error } & 4 \\ \text { C. Total } 5\end{array}$ 0
0

Means for Oneway Anova

Level Number Mean Std Error Lower 95\% Upper 95\% $\begin{array}{llrrrr}1 & 3 & 0.005857 & 0 & 0.00586 & 0.00586\end{array}$

Std Error uses a pooled estimate of error variance
Glass ID=Ustd

Oneway Analysis of Cro3 (wt \%) By Block

Reference Value $=0 \mathrm{wt} \%$

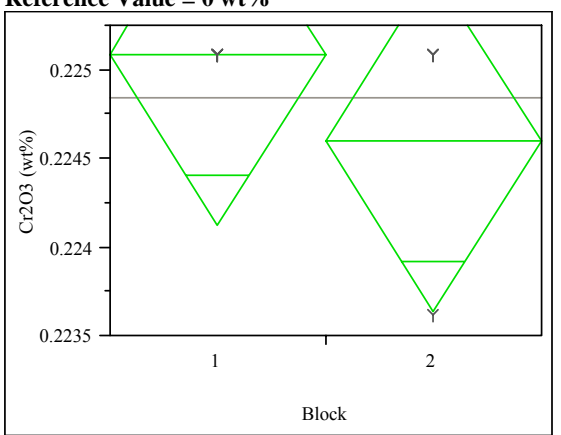

Oneway Anova

Rsquare

Adj Rsquare

$-9.5 \mathrm{e}-15$
Root 15

quare Error $\quad 0.000597$

Mean of Response 0.224843
6

Test

$1-2$

Assuming equal variances

Difference $\quad 0.00049$ t Ratio

$\begin{array}{llll}\text { Std Err Dif } & 0.00049 & \text { DF } & 4 \\ \text { Upper CL Dif } & 0.00184 \text { Prob }>|t| & 0.3739\end{array}$

Lower CL Dif -0.00087 Prob $>t \quad 0.1870$

$\begin{array}{llll}\text { Confidence } & 0.95 \text { Prob }<\mathrm{t} \quad 0.8130\end{array}$

Analysis of Variance

Source DF Sum of Squares Mean Square F Ratio Prob $>$ F $\begin{array}{lllllll}\text { Block } & 1 & 3.56046 \mathrm{e}-7 & 3.5605 \mathrm{e}-7 & 1.0000 & 0.3739\end{array}$ $\begin{array}{llll}\text { Error } & 4 & 0.00000142 & 3.5605 \mathrm{e}-7\end{array}$

C. Total $5 \quad 0.00000178$

Means for Oneway Anova

Level Number Mean Std Error Lower 95\% Upper 95\% $\begin{array}{llllll}3 & 0.225086 & 0.00034 & 0.22413 & 0.22604\end{array}$ $\begin{array}{llllll}2 & 3 & 0.224599 & 0.00034 & 0.22364 & 0.22556\end{array}$

Std Error uses a pooled estimate of error variance
Glass ID=Ustd

Oneway Analysis of $\mathrm{CuO}$ (wt\%) By Block

Reference Value $=0 \mathrm{wt} \%$

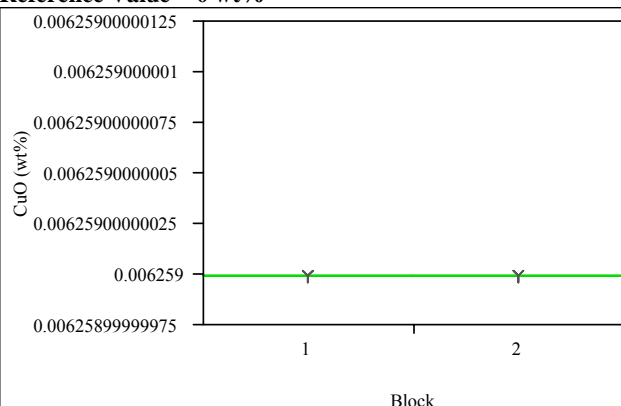

Oneway Anova

Summary of Fit

Rsquare

Adj Rsquare

Root Mean Square Erro

Mean of Response

Observations (or Sum Wgts) $\quad 6$

t Tes

Assuming equal variances

$\begin{array}{lllr}\text { Difference } & 0 & \text { t Ratio } & \\ \text { Std Err Dif } & 0 & \text { DF } & 4 \\ \text { Upper CL Dif } & 0 & \text { Prob }>|t| & 1.0000 \\ \text { Lower CL Dif } & 0 & \text { Prob }>\text { t } & 0.5000 \\ \text { Confidence } & 0.95 & \text { Prob }<t & 0.5000\end{array}$

Analysis of Variance

Source DF Sum of Squares Mean Square F Ratio Prob $>$ F Block $11 \quad 0 \quad 0$

$\begin{array}{lll}\text { C. Total } & 5 & \end{array}$

Means for Oneway Anova

Level Number Mean Std Error Lower 95\% Upper 95\% $\begin{array}{llllll}1 & 3 & 0.006259 & 0 & 0.00626 & 0.00626 \\ 2 & 3 & 0.006259 & 0 & 0.00626 & 0.00626\end{array}$

Std Error uses a pooled estimate of error variance 


\section{Exhibit D3. PSAL Measurements by Analytical Block for Samples of the Standard Glasses Prepared Using the LM Method (continued)}

Glass ID=Ustd

Oneway Analysis of $\mathrm{K2O}$ (wt\%) By Block

Reference Value $=2.999 \mathrm{wt} \%$

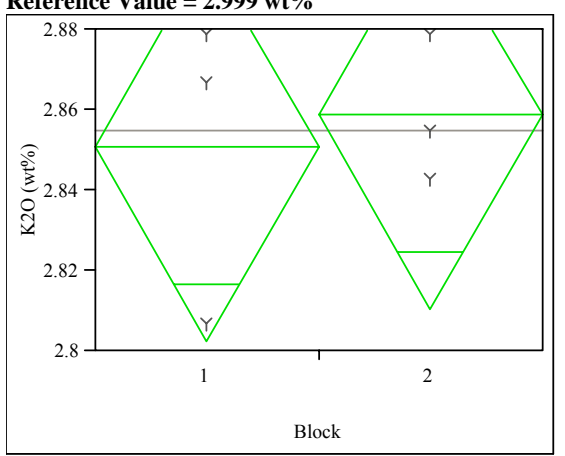

Oneway Anova

Summary of Fit

Rsquare

0.025641

Adj Rsquare $\quad-0.21795$

$\begin{array}{ll}\text { Root Mean Square Error } & 0.030315 \\ \text { Mean of Response } & 2.854902\end{array}$

Mbservations (or Sin

2.854902

Observations (or Sum Wgts)

t Test

Assuming equal variances

Difference $\quad-0.00803$ t Ratio $\quad-0.32444$ td Err Dif $\quad 0.02475$ D

4
0.7619

Upper CL Dif $\quad 0.06069$ Prob $>|t| \quad 0.7619$

$\begin{array}{lll}\text { Lower CL Dif } & 0.07675 \text { Prob }>t \quad 0.619 \\ 0.95 \text { Pro }<\text { t } & 0.3809\end{array}$

Analysis of Variance

Analysis of Variance
Source DF Sum of Squares Mean Square F Ratio Prob > F

$\begin{array}{lrrrrrr}\text { Source } & \text { DF } & \text { Sum of Squares } & \text { Mean Square } & \text { F Ratio } & \text { Prob }>\text { F } \\ \text { Block } & 1 & 0.00009674 & 0.000097 & 0.1053 & 0.7619\end{array}$

$\begin{array}{llll}\text { Block } & 1 & 0.00009674 & 0.000097 \\ \text { Error } & 4 & 0.00367602 & 0.000919\end{array}$

C. Total $5 \quad 0.00377276$

Means for Oneway Anova

Level Number Mean Std Error Lower 95\% Upper 95\%

$\begin{array}{llllll}1 & 3 & 2.85089 & 0.01750 & 2.8023 & 2.8995 \\ 2 & 3 & 2.85892 & 0.01750 & 2.8103 & 2.9075\end{array}$

Std Error uses a pooled estimate of error variance
Glass ID=Ustd

Oneway Analysis of La203 (wt\%) By Block

Reference Value $=0 \mathrm{wt}^{\circ}$

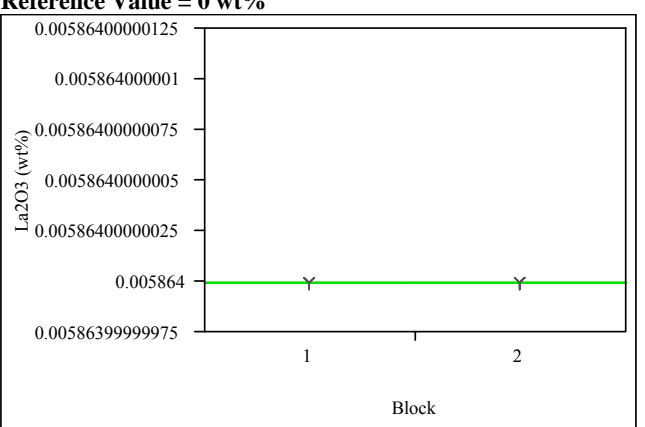

Oneway Anova

Summary of Fit

Rsquare

Adj Rsquare

Root Mean Square Erro

Mean of Response

Observations (or Sum Wgts) $\quad 6$

t Tes

Assuming equal variances

\section{Difference $\quad 0$ t Ratio}

Std Err Dif $\quad 0$ DF

Upper CL Dif 0 Prob $>|t| 1.0000$

Lower CL Dif 0 Prob $>$ t 0.5000

Analysis of Variance

Source DF Sum of Squares Mean Square F Ratio Prob $>$ F $\begin{array}{lrrr}\text { Source } & \text { DF } & \text { Sum of Squares } & \text { Mean Square } \\ \text { Block } & 1 & 0 & 0 \\ & 4 & 0\end{array}$

$\begin{array}{lll}\text { Error } & 4 & 0 \\ \text { C. Total } & 5 & 0\end{array}$

Means for Oneway Anova

Means for Oneway Anova
Level Number Mean Std Error Lower 95\% Upper 95\%

$\begin{array}{rrrrrr}\text { Level Number } & \text { Mean } & \text { Std Error } & \text { Lower 95\% } & \text { Upper 95\% } \\ 1 & 3 & 0.005864 & 0 & 0.00586 & 0.00586\end{array}$

$\begin{array}{llllll}1 & 3 & 0.005864 & 0 & 0.00586 & 0.00586 \\ 2 & 3 & 0.005864 & 0 & 0.00586 & 0.00586\end{array}$

Std Error uses a pooled estimate of error variance
Glass ID=Ustd

Oneway Analysis of $\mathrm{MgO}$ (wt\%) By Block

Reference Value $=1.21 \mathrm{wt} \%$

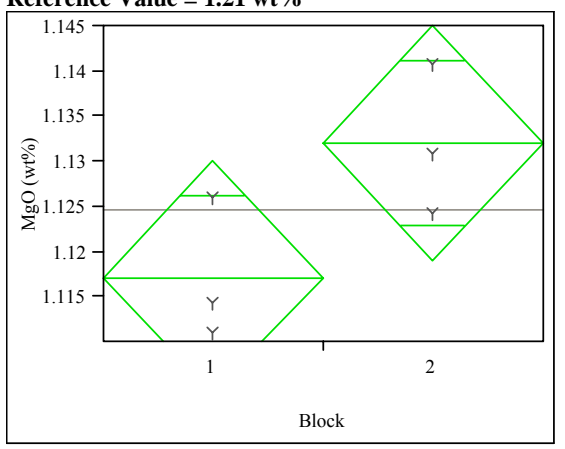

\section{Oneway Anova}

Summary of Fit

$\begin{array}{ll}\text { Rsquare } & 0.560338 \\ & 0.450423\end{array}$

Root Mean Square Error $\quad 0.008096$

Mean of Response $\quad 1.124604$

Observations (or Sum Wgts)

t Test

Assuming equal variances

Difference $\quad-0.01492$ t Ratio $\quad-2.25785$

$\begin{array}{lrr}\text { Std Err Dif } & 0.00661 \text { DF } & 4 \\ \text { DF } & & -2.25785\end{array}$

Upper CL Dif 0.00343 Prob $>|t| 0.0869$

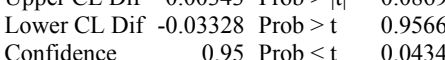

Analysis of Variance

Source DF Sum of Squares Mean Square F Ratio Prob $>$ F $\begin{array}{llllll}\text { Block } & 1 & 0.00033412 & 0.000334 & 5.0979 & 0.0869\end{array}$ $\begin{array}{llll}\text { Error } & 4 & 0.00026216 & 0.000066\end{array}$

C. Total $5 \quad 0.0005962$

Means for Oneway Anova

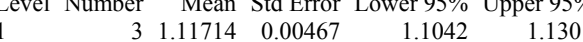

$\begin{array}{llllll}1 & 3 & 1.11714 & 0.00467 & 1.1042 & 1.1301 \\ & 3 & 1.13207 & 0.00467 & 1.1191 & 1.1450\end{array}$

Std Error uses a pooled estimate of error variance 


\section{Exhibit D3. PSAL Measurements by Analytical Block for Samples of the Standard Glasses Prepared Using the LM Method (continued)}

Glass ID=Ustd

Oneway Analysis of $\mathrm{MnO}(\mathrm{wt} \%)$ By Block

Reference Value $=\mathbf{2 . 8 9 2} \mathrm{wt} \%$

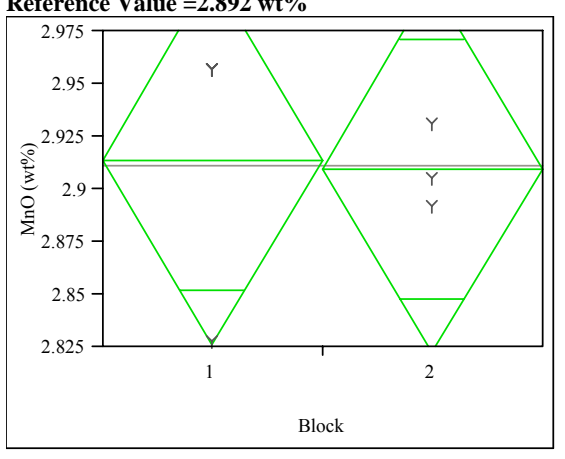

Oneway Anova

\section{Rsquare $\quad 0.002331$}

Adj Rsquare

-0.24709
0.054527

Mean of Response

2.911656

Observations (or Sum Wgts)

t Test

Assuming equal variances

Difference $\quad 0.00430$ t Ratio $\quad 0.096674$

Std Err Dif 0.04452 DF

Upper CL Dif 0.12791 Prob $>|t| \quad 0.9276$

$\begin{array}{lrll}\text { Lower CL Dif } & -0.11931 & \text { Prob }>t & 0.4638 \\ \text { Confidence } & 0.95 & \text { Prob }<t & 0.5362\end{array}$

Analysis of Variance

Source DF Sum of Squares Mean Square F Ratio Prob $>$ F $\begin{array}{llllll}\text { Block } & 1 & 0.00002779 & 0.000028 & 0.0093 & 0.9276\end{array}$ $\begin{array}{llll}\text { Error } & 4 & 0.01189268 & 0.002973\end{array}$

C. Total $5 \quad 0.01192046$

Means for Oneway Anova

Level Number Mean Std Error Lower 95\% Upper 95\%

$\begin{array}{llllll}1 & 3 & 2.91381 & 0.03148 & 2.8264 & 3.0012 \\ 2 & 3 & 2.90950 & 0.03148 & 2.8221 & 2.9969\end{array}$

Std Error uses a pooled estimate of error variance
Glass ID=Ustd

Oneway Analysis of Na2O (wt\%) By Block

Reference Value $=11.795$ wt $\%$

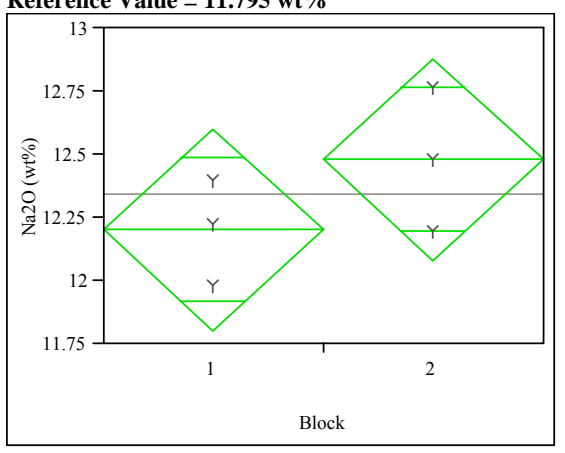

\section{Oneway Anova}

Summary of Fit

$\begin{array}{lr}\text { Rsquare } & 0.319163 \\ \text { Adj Rsquare } & 0.148954 \\ \text { Root Mean Square Error } & 0.249167 \\ \text { Mean of Response } & 12.34319 \\ \text { Observations (or Sum Wgts) } & 6 \\ \text { t Test } & \\ \text { 1-2 } & \\ \text { Assuming equal variances } & \end{array}$

Assuming equal variances

Difference $\quad-0.27859$ t Ratio $\quad-1.36935$

$\begin{array}{lrrr}\text { Std Err Dif } & 0.20344 \text { DF } & 4\end{array}$

Upper CL Dif 0.28627 Prob $>|t| 0.2427$

$\begin{array}{lrl}\text { Lower CL Dif }-0.84344 \text { Prob }>t & 0.8786 \\ \text { 0.95 Prob }<t & 0.1214\end{array}$

Analysis of Variance

Source DF Sum of Squares Mean Square F Ratio Prob $>$ F $\begin{array}{llllll}\text { Block } & 1 & 0.11641580 & 0.116416 & 1.8751 & 0.2427\end{array}$ $\begin{array}{llll}\text { Error } & 4 & 0.24833755 & 0.062084\end{array}$

C. Total $5 \quad 0.36475334$

Means for Oneway Anova

Level Number Mean Std Error Lower 95\% Upper 95\%

$\begin{array}{lrrrrr}1 & 3 & 12.2039 & 0.14386 & 11.804 & 12.603 \\ 2 & 3 & 12.4825 & 0.14386 & 12.083 & 12.882\end{array}$

Std Error uses a pooled estimate of error variance
Glass ID=Ustd

Oneway Analysis of PbO (wt\%) By Block

Reference Value $=0 \mathrm{wt} \%$

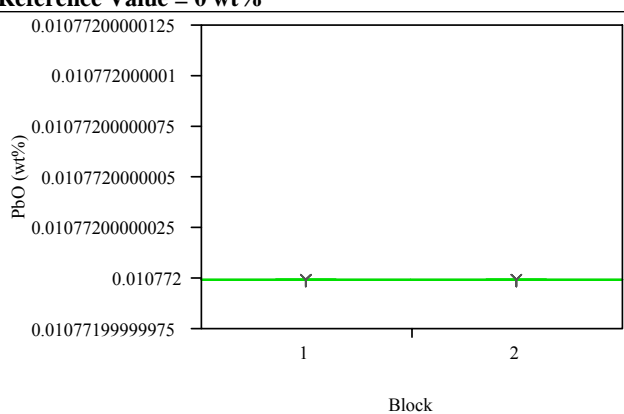

Oneway Anova

Summary of Fit

Rsquare

Adj Rsquare

Root Mean Square Error $\quad \begin{array}{r}-0.25 \\ 2.12-18\end{array}$

Mean of Respons

Observations (or Sum Wgts) 0.010772

Test

Assuming equal variances

$\begin{array}{lrr}\text { Difference } & 0 \text { t Ratio } & 0 \\ \text { Std Err Dif } & 1.735 \mathrm{e}-18 \mathrm{DF} & 4\end{array}$

$\begin{array}{lrlr}\text { Std Err Dif } & 1.735 \mathrm{e}-18 & \mathrm{DF} & 4 \\ \text { Upper CL Dif } & 4.816 \mathrm{e}-18 & \text { Prob }>|t| & 1.0000\end{array}$

$\begin{array}{llll}\text { Upper CL Dif } & 4.816 \mathrm{e}-18 & \text { Prob }>|\mathrm{t}| & 1.0000 \\ \text { Lower CL Dif } & -4.82 \mathrm{e}-18 & \text { Prob }>\mathrm{t} & 0.5000\end{array}$

$\begin{array}{rrrr}\text { Lower CL Dif } & -4.82 \mathrm{e}-18 & \text { Prob }>\mathrm{t} & 0.5000 \\ \text { Confidence } & 0.95 & \text { Prob }<\mathrm{t} & 0.5000\end{array}$

Analysis of Variance

Source DF Sum of Squares Mean Square F Ratio Prob $>$ F

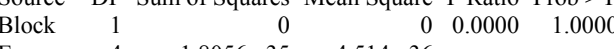
$\begin{array}{llll}\text { Error } & 4 & 1.8056 \mathrm{e}-35 & 4.514 \mathrm{e}-36\end{array}$

C. Total 5 1.8056e-35

Level Number Mean Std Error Lower 95\% Upper 95\% $\begin{array}{rrrrrr}1 & 3 & 0.010772 & 1.227 \mathrm{e}-18 & 0.01077 & 0.01077 \\ 1 & 3 & 0.010772 & 1.227 \mathrm{e}-18 & 0.01077 & 0.01077\end{array}$ Std Error uses a pooled estimate of 


\section{Exhibit D3. PSAL Measurements by Analytical Block for Samples of the Standard Glasses Prepared Using the LM Method (continued)}

Glass ID=Ustd

Oneway Analysis of $\mathrm{SO} 4$ (wt\%) By Block Reference Value $=0 \mathrm{wt} \%$

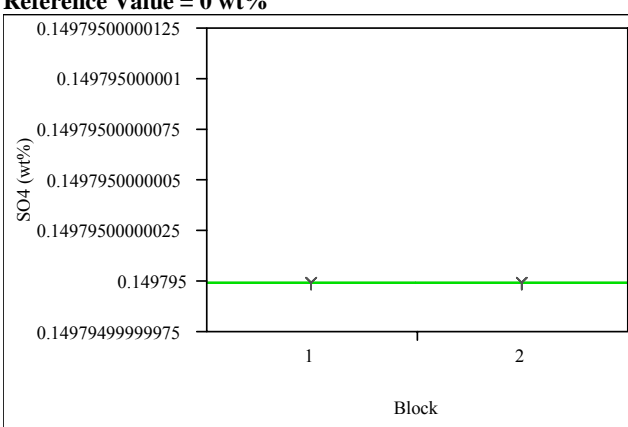

Oneway Anova

Summary of Fit

Rsquare

Adj Rsquare

Root Mean Square Erro

Mean of Respons

0.149795

t Test

$1-2$ Assuming equat varinces

\section{Difference \\ 0 t Ratio \\ 4 \\ Lower CL Dif 0 Prob $>$ t 0.5000 \\ Confidence 0.95 Prob $<$ t 0.5000}

Analysis of Variance

Source DF Sum of Squares Mean Square F Ratio Prob $>$ F Block 1100

Error 4

Means for Oneway Anova 0
0

Level Number Mean Std Error Lower 95\% Upper 95\% $\begin{array}{lrrrrr}1 & 3 & 0.149795 & 0 & 0.14979 & 0.14979\end{array}$ Std Error uses a pooled estimate of error variance
Glass ID=Ustd

Oneway Analysis of ThO2 (wt\%) By Block

Reference Value $=0 \mathrm{wt}^{\circ} \%$

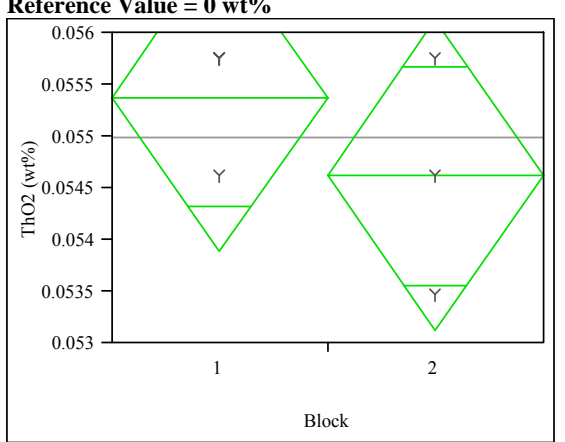

Oneway Anova

Summary of Fit

Rsquare

Adj Rsquare

Root Mean Square Error

$\begin{array}{lr}\text { Mean of Response } & 0.054998 \\ \text { Observations (or Sum Wgts) } & 6\end{array}$

0.2
$-1.1 \mathrm{e}-15$

0.000929

t Test

$1-2$

Assuming equal variances

Difference $\quad 0.00076$ t Ratio

$\begin{array}{llll}\text { Std Err Dif } & 0.00076 & \mathrm{DF} & 4 \\ \text { Upper CL Dif } & 0.00286 & \text { Prob }>|t| & 0.3739\end{array}$

Lower CL Dif -0.00135 Prob $>t \quad 0.1870$

$\begin{array}{llll}\text { Confidence } & 0.95 \text { Prob }<\mathrm{t} \quad 0.8130\end{array}$

Analysis of Variance

Source DF Sum of Squares Mean Square F Ratio Prob > $\begin{array}{llllll}\text { Block } & 1 & 8.63211 \mathrm{e}-7 & 8.6321 \mathrm{e}-7 & 1.0000 & 0.3739\end{array}$ $\begin{array}{llll}\text { Error } & 4 & 0.00000345 & 8.6321 \mathrm{e}-7\end{array}$

C. Total $5 \quad 0.00000432$

Means for Oneway Anova

Level Number Mean Std Error Lower 95\% Upper 95\%

$\begin{array}{llllll}3 & 0.055378 & 0.00054 & 0.05389 & 0.05687\end{array}$

$\begin{array}{llllll}2 & 3 & 0.054619 & 0.00054 & 0.05313 & 0.05687 \\ & & 0.05611\end{array}$

Std Error uses a pooled estimate of error variance
Glass ID=Ustd

Oneway Analysis of TiO2 (wt\%) By Block

Reference Value $=1.049 \mathrm{wt} \%$

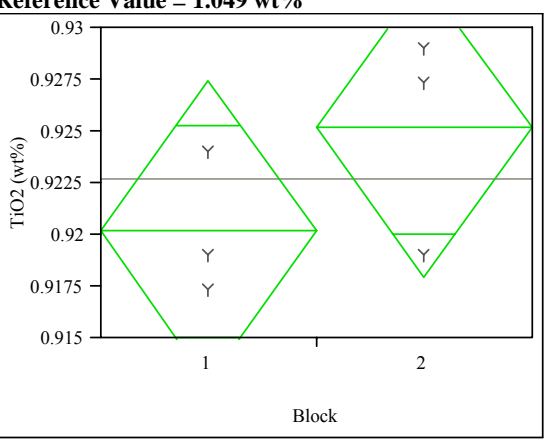

Oneway Anova

Summary of Fit

Adj Rsquare $\quad 0.315175$

Root Mean Square Error $\quad 0.004517$

$\begin{array}{lr}\text { Mean of Response } & 0.922682 \\ \text { Observations (or Sum Wgts) } & 6\end{array}$

t Test

$1-2$

Assuming equal variances

Difference $\quad-0.00500$ t Ratio -1.3568

$\begin{array}{lrrr}\text { Std Err Dif } & 0.00369 & \mathrm{DF} & 4 \\ \text { Upper CL Dif } & 0.00524 \text { Prob }>|\mathrm{t}| & 0.2464\end{array}$

Lower CL Dif -0.01524 Prob $>t \quad 0.8768$

$\begin{array}{lll}\text { Confidence } & 0.95 \text { Prob }<\mathrm{t} \quad 0.1232\end{array}$

Analysis of Variance

Source DF Sum of Squares Mean Square F Ratio Prob $>$ F $\begin{array}{llllll}\text { Block } & 1 & 0.00003756 & 0.000038 & 1.8409 & 0.2464\end{array}$ $\begin{array}{llll}\text { Error } & 4 & 0.00008161 & 0.000020\end{array}$

C. Total $5 \quad 0.0001191$

Means for Oneway Anova

Level Number Mean Std Error Lower 95\% Upper 95\%

$\begin{array}{llllll}3 & 0.920180 & 0.00261 & 0.91294 & 0.92742\end{array}$

$\begin{array}{llllll}2 & 3 & 0.925184 & 0.00261 & 0.91794 & 0.93242\end{array}$

Std Error uses a pooled estimate of error variance 


\section{Exhibit D3. PSAL Measurements by Analytical Block for Samples of the} Standard Glasses Prepared Using the LM Method (continued)

\section{Glass ID=Ustd}

Oneway Analysis of $\mathrm{ZnO}$ (wt\%) By Block

Reference Value $=0 \mathrm{wt} \%$

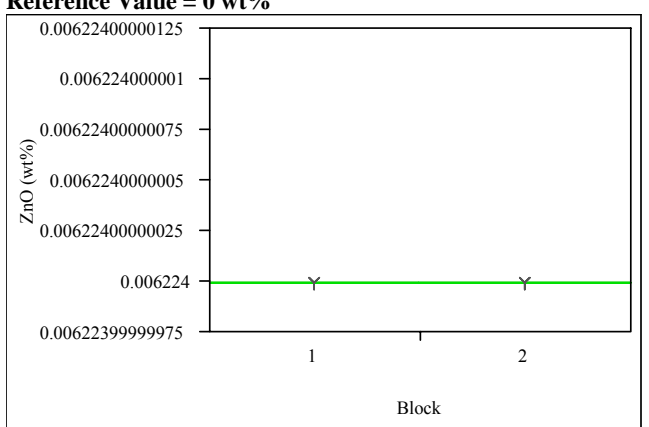

Oneway Anova

Summary of Fit

Rsquare

Adj Rsquare

Root Mean Square Erro

Mean of Response

Observations (or Sum Wgts) $\begin{array}{r}0.006224 \\ \hline\end{array}$

t Tes

Assuming equal variances

Difference $\quad 0$ t Ratio

$0 \mathrm{DF}$

Upper CL Dif $\quad 0$ Prob $>|t| 1.0000$

Lower CL Dif 0 Prob $>$ t 0.5000

Analysis of Variance

Source DF Sum of Squares Mean Square F Ratio Prob $>$ F $\begin{array}{lrrr}\text { Source } & \text { DF } & \text { Sum of Squares } & \text { Mean Square } \\ \text { Block } & 1 & 0 & 0 \\ & 4 & 0\end{array}$

Error 4

C. Total 5
Means for Oneway Anova

Mevel Number Mean Std Error Lower 95\% Upper 95\%

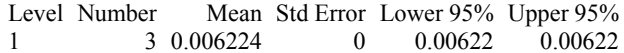
$\begin{array}{llllll}1 & 3 & 0.006224 & 0 & 0.00622 & 0.00622 \\ 2 & 3 & 0.006224 & 0 & 0.00622 & 0.00622\end{array}$

Std Error uses a pooled estimate of error variance
Glass ID=Ustd

Oneway Analysis of ZrO2 (wt\%) By Block

Reference Value $=0 \mathrm{wt} \%$

0.00675400000125

0.006754000001

$0^{0.00675400000075}$

这 0.0067540000005

ง 0.00675400000025

0.00675399999975

.006754

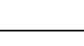

Block

Oneway Anova

ummary of Fit

Rsquare

Adj Rsquare

Root Mean Square Erro

Mean of Respon

Observations (or Sum Wgts)

Test

Assuming equal variances

Difference $\quad 0$ t Ratio

$\begin{array}{llll}\text { Std Err Dif } & 0 & \mathrm{DF} & 4\end{array}$

$\begin{array}{lll}\text { Upper CL Dif } & 0 \text { Prob }>|t| 1.0000\end{array}$

$\begin{array}{lrrr}\text { Lower CL Dif } & 0 & \text { Prob }>t & 0.5000 \\ \text { Confidence } & 0.95 & \text { Prob }<t & 0.5000\end{array}$

Analysis of Variance

Source DF Sum of Squares Mean Square F Ratio Prob $>$ F Block $11 \quad 0 \quad 0$

$\begin{array}{lll}\text { Error } & 4 & 0 \\ \text { C. Total } & 5 & 0\end{array}$

Means for Oneway Anova

Means for Oneway Anova
Level Number Mean Std Error Lower 95\% Upper 95\%

$\begin{array}{rrrrrr}\text { Level Number } & \text { Mean } & \text { Std Error } & & & \\ 1 & 3 & 0.006754 & 0 & 0.00675 & 0.00675 \\ & 3 & 0.00654 & 0 & 0.0065 & 0.00675\end{array}$

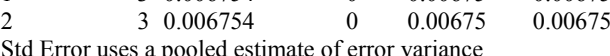




\section{Exhibit D4: PSAL Measurements by Analytical Block for Samples of the Standard Glasses Prepared Using the PF Method}

Glass ID=Batch 1

Oneway Analysis of Al2O3 (wt\%) By Block Reference Value $=4.877 \mathrm{wt} \%$

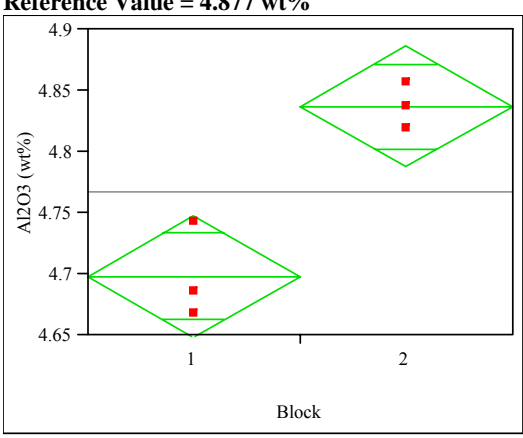

Oneway Anova

ummary of Fit

$\begin{array}{ll}\text { Rsquare } & 0.883212 \\ \text { Adj Rsqure } & 0.854015\end{array}$

Root Mean Square Error $\quad 0.854015$

Mean of Response

0.030855

Observations (or Sum Wgts)

t Test

Assuming equal variances Std Err Dif $\quad 0.02519$ DF

Upper CL Dif -0.06862 Prob $>|t| 0.0053$

Lower CL Dif -0.20851 Prob $>|t| 0.005$

0.95 Prob $<$ t 0.997

Analysis of Variance

Source DF Sum of Squares Mean Square F Ratio Prob $>$ F

$\begin{array}{lllllll}\text { Block } & 1 & 0.02879970 & 0.028800 & 30.2500 & 0.0053\end{array}$ $\begin{array}{llll}\text { Error } & 4 & 0.00380822 & 0.000952\end{array}$

C. Total $5-0.03260792$

Means for Oneway Anova

Level Number Mean Std Error Lower 95\% Upper 95\%

$\begin{array}{llrrrr}1 & 3 & 4.69856 & 0.01781 & 4.6491 & 4.7480\end{array}$

Std Error uses a pooled estimte of error variance
Glass ID=Batch 1

Oneway Analysis of B2O3 (wt\%) By Block

Oneway Analysis of $\mathrm{B} 2 \mathrm{O} 3(\mathrm{w} \%$
Reference Value $=7.777 \mathrm{wt} \%$

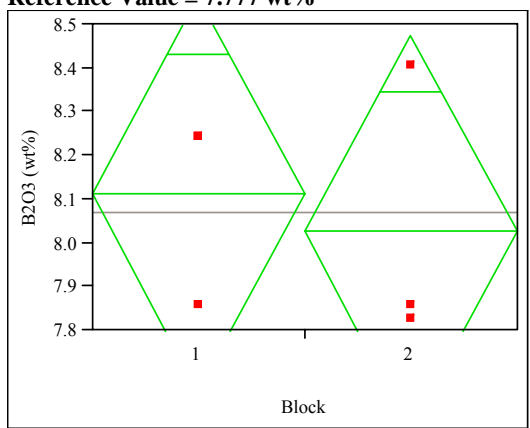

Oneway Anova

Summary of Fit

Rsquare

Adj Rsquare

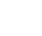

0.03426
-0.20717
0.279161

Root Mean Square Error $\quad 0.27916$

\begin{tabular}{l}
8.071216 \\
\hline
\end{tabular}

Test

Assuming equal variances

\section{Difference $\quad 0.08586$ t Ratio $\quad 0.376705$ \\ $\begin{array}{llr}\text { Difference } & 0.08586 \text { t Ratio } & 0.376705 \\ \text { Std Err Dif } & 0.22793 \mathrm{DF} & 4\end{array}$ \\ $\begin{array}{lll}\text { Std Err Dif } & 0.22793 & \mathrm{DF} \\ \text { Upper CL Dif } & 0.71871 \quad \text { Prob }>|t| & 0.7255\end{array}$

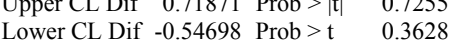

$\begin{array}{lll}\text { Confidence } & 0.95 \text { Prob }<\mathrm{t} \quad 0.6372\end{array}$

Analysis of Variance

Source DF Sum of Squares Mean Square F Ratio Prob $>$ F $\begin{array}{llllll}\text { Block } & 1 & 0.01105894 & 0.011059 & 0.1419 & 0.7255\end{array}$

$\begin{array}{lll}\text { Error } & 4 & 0.31172386\end{array}$

C. Torn for Oneway 0.32278280

Level Number Mean Std Error Lower 95\% Upper 95\%

\begin{tabular}{lrrrrr}
1 & 3 & 8.11415 & 0.16117 & 7.6667 & 8.5616 \\
\hline
\end{tabular}

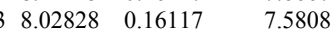

8.4758
Glass ID=Batch 1

Oneway Analysis of Fe2O3 (wt\%) By Block Reference Value $=12.839 \mathrm{wt} \%$

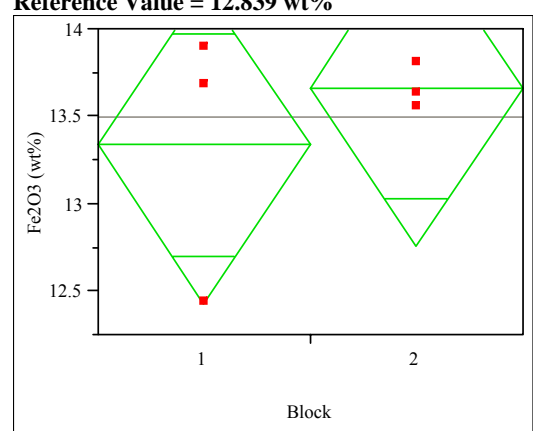

Oneway Anova

Summary of Fit

Rsquare

Root Mean Square Error $\quad-0.108415$

Root of Response $\quad 0.564415$

Observations (or Sum Wgts)

t Test

Assuming equal variances

Difference $\quad-0.3288$ t Ratio $\quad-0.71354$ Std Err Dif $\quad 0.4608$ D

Upper CL Dif 0.9507 Prob $>|1|-0.5149$

$\begin{array}{lll}\text { Confidence } & 0.95 \text { Prob }<\mathrm{t} \quad 0.2575\end{array}$

Analysis of Variance

Source DF Sum of Squares Mean Square F Ratio Prob $>$ F $\begin{array}{lrrrrr}\text { Block } & 1 & 0.1621947 & 0.162195 & 0.5091 & 0.5149\end{array}$

$\begin{array}{llll}\text { Error } & 4 & 1.2742558 & 0.318564\end{array}$

1.4364506

Means for Oneway Anova

Level Number Mean Std Error Lower 95\% Upper 95\% $\begin{array}{llllll}1 & 3 & 13.3391 & 0.32586 & 12.434 & 14.244 \\ 2 & 3 & 13.6679 & 0.32586 & 12.763 & 14.573\end{array}$ Std Error uses a pooled estimate of error variance 


\section{Exhibit D4: PSAL Measurements by Analytical Block for Samples of the Standard Glasses Prepared Using the PF Method (continued)}

Glass ID=Batch 1

Oneway Analysis of Li2O (wt\%) By Block

Reference Value $=4.429 \mathrm{wt} \%$

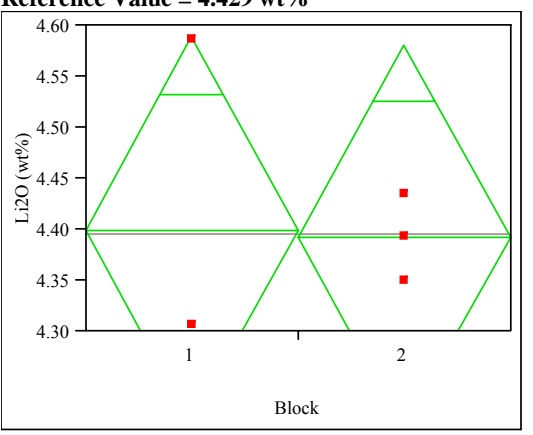

Oneway Anova

Summary of Fit

Rsquare

Adj Rsquare

0.001379

Root Mean Squa

$-0.24828$

Mean of Response

4.395504

Observations (or Sum Wgts)

t Tes

$1-2$

Assuming equal variances

Difference $\quad 0.00718$ t Ratio $\quad 0.074329$

Std Err Dif 0.09655 DF

Upper CL Dif 0.27524 Prob $>|t| \quad 0.944$

Lower CL Dif -0.26088 Prob $>t \quad 0.4722$

Confidence

0.95 Prob $<t$

Analysis of Variance

Source DF Sum of Squares Mean Square F Ratio Prob $>$ F $\begin{array}{llllll}\text { Block } & 1 & 0.00007725 & 0.000077 & 0.0055 & 0.9443\end{array}$ $\begin{array}{llll}\text { Error } & 4 & 0.05592874 & 0.013982\end{array}$

C. Total $5 \quad 0.0560059$

Means for Oneway Anova

Level Number Mean Std Error Lower 95\% Upper 95\%

$\begin{array}{llllll}1 & 3 & 4.39909 & 0.06827 & 4.2095 & 4.5886\end{array}$

$\begin{array}{rrrr}2 & 4.39192 & 0.06827 & 4.2024 \\ \text { Std Error uses a pooled estimate of error variance }\end{array}$
Glass ID=Batch 1

Oneway Analysis of NiO (wt\%) By Block

Reference Value $=\mathbf{0 . 7 5 1} \mathbf{w t} \%$

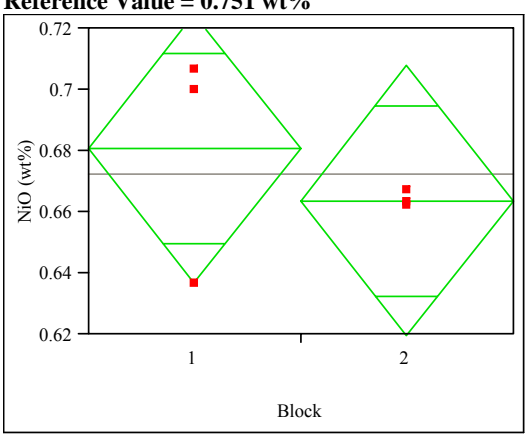

Oneway Anova

Summary of Fit

Rsquare

$\begin{array}{lr}\text { Adj Rsquare } & -0.09316 \\ \text { Root Mean Square Error } & 0.02743\end{array}$

Met Mean Square Error $\quad 0.02743$ 0.672304

t Test

Assuming equal variances

Difference $\quad 0.01697$ t Ratio $\quad 0.757554$

Std Err Dif 0.02240 D

Upper CL Dif 0.07915 Prob $>|t| \quad 0.490$

Lower CL Dif -0.04522 Prob $>t \quad 0.245$

Confidence

0.7546

\section{Analysis of Variance}

Source DF Sum of Squares Mean Square F Ratio Prob $>$ F $\begin{array}{llllll}\text { Block } & 1 & 0.00043180 & 0.000432 & 0.5739 & 0.4909\end{array}$ $\begin{array}{lll}\text { Error } & 4 & 0.00300966\end{array}$ 0.000752

C. Total 50.00344146

Means for Oneway Anova
Level Number Mean Std Error Lower 95\% Upper 95\%

$\begin{array}{lllllll}1 & 3 & 0.680788 & 0.01584 & 0.63682 & 0.72476\end{array}$

$\begin{array}{lllll}2 & 3 & 0.663821 & 0.01584 & 0.6198\end{array}$
Glass ID=Batch 1

(wt\%) By Block

Reference Value $=50.22$ wt $\%$

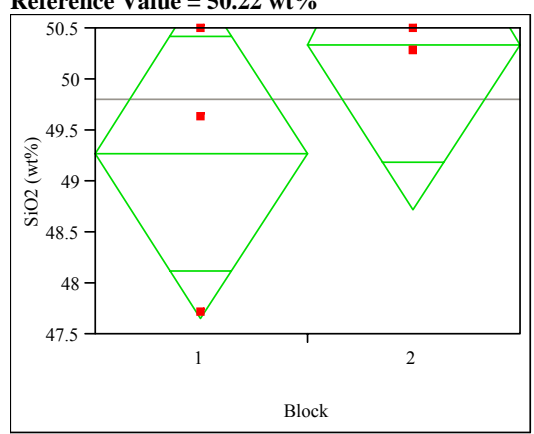

Oneway Anova

Summary of Fit

Rsquare

Adj Rsquare $\quad 0.295664$

Root Men Square Error $\quad 0.11958$

Met Men Square Error $\quad 1.010994$

Observations (or Sum Wgts)

t Test

$1-2$

Assuming equal variances

Difference $\quad-1.0697$ t Ratio $\quad-1.2958$

Std Err Dif $\quad 0.8255$ DF

Upper CL Dif 1.2222 Prob $>|t| 0.2648$

Lower CL Dif -3.3615 Prob $>$ t 0.8676

$\begin{array}{lll}\text { Confidence } \quad 0.95 \text { Prob }<\mathrm{t} \quad 0.1324 & \end{array}$

Analysis of Variance

DF Sum of Squares Mean Square F Ratio Prob > F $\begin{array}{lrrrrr}\text { Block } & 1 & 1.7162267 & 1.71623 & 1.6791 & 0.2648\end{array}$ $\begin{array}{llll}\text { Error } & 4 & 4.0884333 & 1.0221\end{array}$

C. Total $5 \quad 5.8046600$

Level Number Mean Std Error Lower 95\% Upper 95\% $\begin{array}{lrrrrr}\text { Level } & \text { Number } & \text { Mean } & \text { Std Error } & \text { Lower 95\% } & \text { Upper 95\% } \\ 1 & 3 & 49.2752 & 0.58370 & 47.655 & 50.896\end{array}$

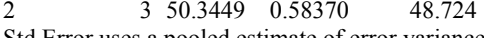
51.965 


\section{Exhibit D4: PSAL Measurements by Analytical Block for Samples of the Standard Glasses Prepared Using the PF Method (continued)}

Glass ID=Batch 1

Oneway Analysis of U3O8 (wt\%) By Block

Reference Value $=0 \mathrm{wt} \%$

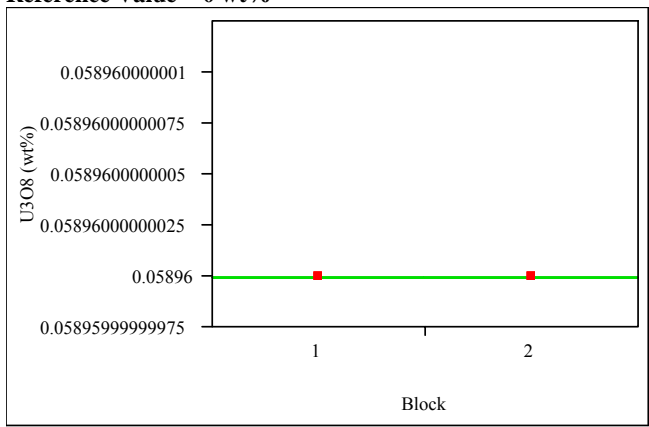

\section{Oneway Anova}

Summary of Fit

Rsquare

Adj Rsquare

Root Mean Square Erro

Mean of Response

Observations (or Sum Wgts)

t Test

$1-2$

Assuming equal variances

Difference

Std Err Dif

0 t Ratio
0 DF

Confidence

\section{Analysis of Variance}

Source DF Sum of Squares Mean Square F Ratio Prob > F 0

Error

0

C. Total

Level Number Mean Std Error Lower 95\% Upper 95\% $\begin{array}{llllll}1 & 3 & 0.058960 & 0 & 0.05896 & 0.05896 \\ 2 & 3 & 0.058960 & 0 & 0.05896 & 0.05896\end{array}$ Std Error uses a pooled estimate of error variance
Glass ID=Ustd

Oneway Analysis of Al2O3 (wt \%) By Block

Reference Value $=4.1 \mathrm{wt} \%$

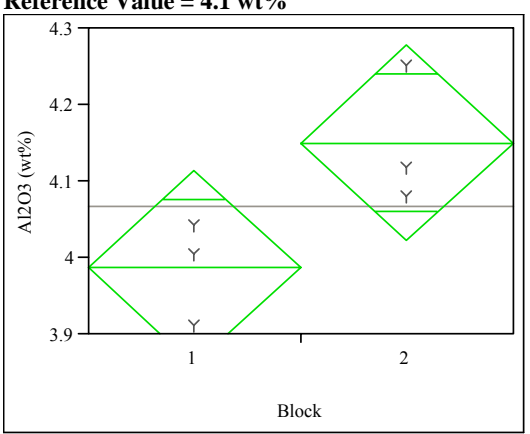

Oneway Anova

Summary of Fit

Rsquare

0.614545

Adj Rsquare

0.518182

Root Mean Square Error $\quad 0.079419$

Mean of Response 4.068723

Observations (or Sum Wgts)

Test

Assuming equal variances

$\begin{array}{lll}\text { Difference } & -0.16376 \text { t Ratio } \quad-2.52534\end{array}$

Std Err Dif 0.06485 DF

Upper CL Dif 0.01628 Prob $>|t| \quad 0.0650$

Lower CL Dif -0.34380 Prob $>t \quad 0.9675$

Confidence

$$
0.95 \text { Prob }<\mathrm{t} \quad 0.0325
$$

\section{Analysis of Variance}

Source DF Sum of Squares Mean Square F Ratio Prob $>$ F $\begin{array}{llllll}\text { Block } & 1 & 0.04022437 & 0.040224 & 6.3774 & 0.065\end{array}$

$\begin{array}{lll}\text { Error } & 4 & 0.02522949 \\ \text { C. Total } & 5 & 0.06545385\end{array}$ 0.006307

Means for Oneway Anova

Level Number Mean Std Error Lower 95\% Upper 95\%

$\begin{array}{lrrrrr}1 & 3 & 3.98685 & 0.04585 & 3.8595 & 4.1142\end{array}$

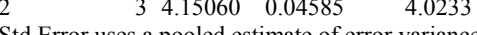

Glass ID=Ustd

Oneway Analysis of B2O3 (wt\%) By Block

Reference Value $=9.209 \mathrm{wt} \%$

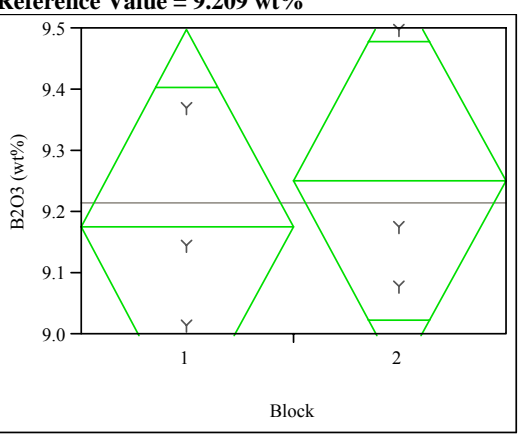

Oneway Anova

Summary of Fit

Rsquare

0.050154

Root Mens Squre Enor $\quad-0.18731$

Met

\begin{tabular}{lr} 
Observations (or Sum Wgts) & 9.21428 \\
\hline
\end{tabular}

t Test

$1-2$

Assuming equal variances

Difference $\quad-0.07513$ t Ratio $\quad-0.45957$

Std Err Dif 0.16348 DF

Upper CL Dif 0.37876 Prob $>|t| \quad 0.6697$

Lower CL Dif -0.52902 Prob $>t \quad 0.6652$

Confidence $\quad 0.95$ Prob $<\mathrm{t} \quad 0.3348$

Analysis of Variance

DF Sum of Squares Mean Square F Ratio Prob $>$ F $\begin{array}{llllll}\text { Block } & 1 & 0.00846700 & 0.008467 & 0.2112 & 0.6697\end{array}$ $\begin{array}{llll}\text { Error } & 4 & 0.16035463 & 0.040089\end{array}$

C. Total 50.16882163

Level Number Mean Std Error Lower 95\% Upper 95\% $\begin{array}{lrrrrr}\text { Level Number } & \text { Mean } & \text { Std Error } & \text { Lower 95\% } & \text { Upper 95\% } \\ 1 & 3 & 9.17671 & 0.11560 & 8.8558 & 9.4977\end{array}$ $\begin{array}{llllll}1 & 3 & 9.17671 & 0.11560 & 8.8558 & 9.4977 \\ 2 & 3 & 9.25185 & 0.11560 & 8.9309 & 9.5728\end{array}$ Std Error uses a pooled estimate of error variance 


\section{Exhibit D4: PSAL Measurements by Analytical Block for Samples of the Standard Glasses Prepared Using the PF Method (continued)}

Glass ID=Ustd

Oneway Analysis of Fe2O3 (wt\%) By Block Reference Value $=13.196 \mathrm{wt} \%$

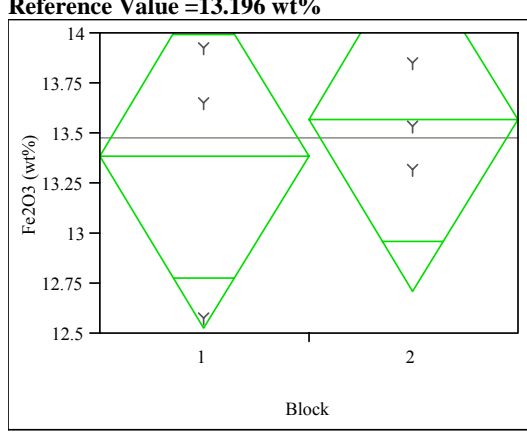

Oneway Anova

Summary of Fit

\begin{tabular}{lll}
-0.19617 \\
\hline
\end{tabular}

-0.19617
Reot Men

(1)

13.47969

Observations (or Sum Wgts)

t Test

Assuming equal variances

Difference $\quad-0.1859$ t Ratio $\quad-0.42426$

$\begin{array}{lrr}\text { Std Err Dif } & 0.4381 \mathrm{DF} & 4 \\ & & \end{array}$

Upper CL Dif 1.0304 Prob $>|t| 0.6932$

Lower CL Dif -1.4022 Prob $>t \quad 0.6534$

Analysis of Variance
Source DF Sum of Squares Mean Square F Ratio Prob $>$ F $\begin{array}{lrrrrr}\text { Source } & \text { DF } & \text { Sum of Squares } & \text { Mean Square } & \text { F Ratio } & \text { Prob }>\text { F } \\ \text { Block } & 1 & 0.0518165 & 0.051816 & 0.1800 & 0.6932\end{array}$

$\begin{array}{llll}\text { Block } & 1 & 0.0518165 & 0.051816 \\ \text { Error } & 4 & 1.1514770 & 0.287869 \\ \text { C. Total } & 5 & 1.2032935 & \end{array}$

Level Number Mean Std Error Lower 95\% Upper 95\%

$\begin{array}{llllll}1 & 3 & 13.3868 & 0.30977 & 12.527 & 14.247\end{array}$

Std Error uses a pooled
Glass ID=Ustd

(wt\%) By Block

Reference Value $=3.057 \mathrm{wt} \%$

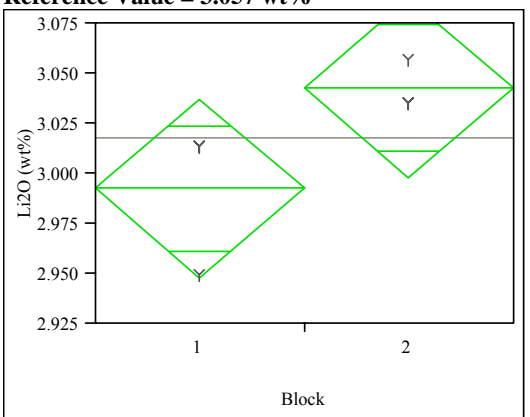

Oneway Anova

Summary of Fit

Rsquare

Oneway Anova

Rsquar

Adj Rsquare $\quad 0.001686$

Root Mean Square Error $\quad-0.2478$

$\begin{array}{lr}\text { Root Mean Square Error } & 0.03792 \\ \text { Mean of Response } & 0.9671\end{array}$

Observations (or Sum Wgts)

Root Mean Square Error $\quad 0.438202$

Mean of Response $\quad 3.017648$

Observations (or Sum Wgts)

Test

Assuming equal variances

Assuming equal variances

Difference $\quad-0.05023$ t Ratio $\quad-2.21359$

$\begin{array}{lrr}\text { Std Err Dif } \quad 0.02269 \mathrm{DF} & 4\end{array}$

Upper CL Dif 0.01277 Prob $>|t| \quad 0.0913$

Lower CL Dif $-0,11324$ Prob $>t$

Analysis of Variance

Source DF Sum of Squares Mean Square F Ratio Prob $>$ F Block $110.00378523 \quad 0.003785$ Ratio Prob $>$ F $\begin{array}{llllll}\text { Error } & 4 & 0.00308999 & 0.000772 & & \end{array}$

C. Total 5 . 0.00687522

Means for Oneway Anova

Level Number Mean Std Error Lower 95\% Upper 95\%

$\begin{array}{lrrrrr}\text { Level } & \text { Number } & \text { Mean } & \text { Std Error } & \text { Lower } 95 \% & \text { Upper } 95 \% \\ 1 & 3 & 2.99253 & 0.01605 & 2.9480 & 3.0371 \\ 2 & 3 & 3.04277 & 0.01605 & 2.9982 & 3.0873\end{array}$

Std Error uses a pooled estimate of error variance

Analysis of Variance
Difference $\quad 0.00255$ t Ratio 0.082199

Std Err Dif $\quad 0.03096$ DF $\quad 4$

Upper CL Dif 0.08851 Prob $>|t| \quad 0.9384$

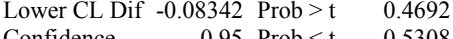

Analysis of Variance
Source DF Sum of Squares Mean Square F Ratio Prob $>$ F $\begin{array}{lrrrrr}\text { Source } & \text { DF } & \text { Sum of Squares } & \text { Mean Square } & \text { F Ratio } & \text { Prob }>\text { F } \\ \text { Block } & 1 & 0.00000972 & 0.00001 & 0.0068 & 0.9384\end{array}$ $\begin{array}{llll}\text { Block } & 1 & 0.00000972 & 0.00001 \\ \text { Error } & 4 & 0.00575160 & 0.001438\end{array}$

$5 \quad 0.0057613$

Means for Oneway Anova

Level Number Mean Std Error Lower 95\% Upper 95\%

$\begin{array}{llllll}1 & 3 & 0.968373 & 0.02189 & 0.90759 & 1.0292 \\ 2 & 3 & 0.965827 & 0.02189 & 0.90504 & 1.0266\end{array}$

Std Error uses a pooled estimate of error variance 


\section{Exhibit D4: PSAL Measurements by Analytical Block for Samples of the Standard Glasses Prepared Using the PF Method (continued)}

\section{Glass ID=Ustd}

Oneway Analysis of $\mathrm{SiO} 2(\mathrm{wt} \%)$ By Block

Reference Value $=45.353 \mathrm{wt} \%$

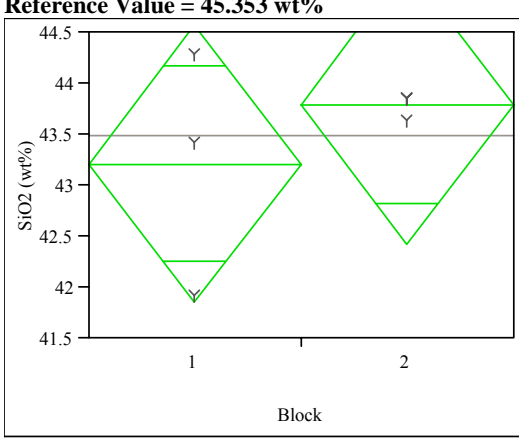

Oneway Anova

Summary of Fit

Rsquare

Adj Rsquare

0.145455

$-0.06818$

Root Mean Square Error $\quad 0.846759$

Mean of Response 43.4991
6

t Test

t-2

Assuming equal variances

Difference $\quad-0.5705$ t Ratio $\quad-0.82514$

Std Err Dif 0.6914 DF

Upper CL Dif 1.3491 Prob $>|t| \quad 0.455$

Lower CL Dif -2.4900 Prob $>t \quad 0.7722$

Confidence

$$
0.95 \text { Prob }<\mathrm{t} \quad 0.2278
$$

Analysis of Variance

Source DF Sum of Squares Mean Square F Ratio Prob $>$ F $\begin{array}{lrrrrr}\text { Source } & \text { DF } & \text { Sum of Squares } & & & \\ \text { Block } & 1 & 0.4881711 & 0.488171 & 0.6809 & 0.4557\end{array}$ Error $\quad 4 \quad 2.8680055$ C. Total $5 \quad 3.356176$

Means for Oneway Anova

Level Number Mean Std Error Lower 95\% Upper 95\%

$\begin{array}{llllll}1 & 3 & 43.2139 & 0.48888 & 41.857 & 44.571 \\ 2 & 3 & 43.7843 & 0.48888 & 42.427 & 45.142\end{array}$

Std Error uses a pooled estimate of error variance
Glass ID=Ustd

Oneway Analysis of U3O8 (wt\%) By Block

Reference Value $=2.406 \mathrm{wt} \%$

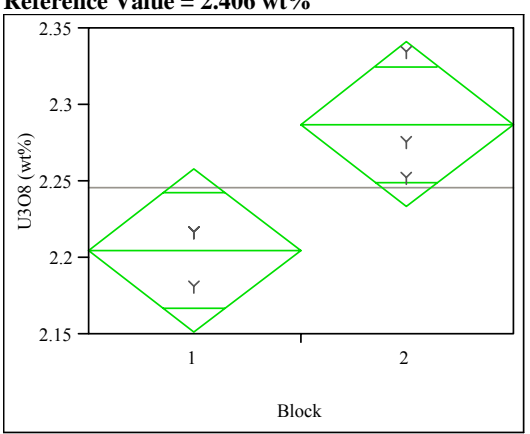

Oneway Anova

Summary of Fit

Rsquare

Adj Rsquare

Root Mean Squ

0.620853

Mean of Respons 2.246376

Observations (or Sum Wgts)

Test

Assuming equal variance

Difference $\quad-0.08254$ t Ratio $\quad-3.03109$

Std Err Dif 0.02723 DF

Upper CL Dif -0.00693 Prob $>|t| 0.0387$

Lower CL Dif -0.15815 Prob $>t \quad 0.9806$

$\begin{array}{lll}\text { Confidence } & 0.95 \text { Prob }<\mathrm{t} \quad 0.0194\end{array}$

\section{Analysis of Variance}

Source DF Sum of Squares Mean Square F Ratio Prob $>$ F

$\begin{array}{lllllll}\text { Block } & 1 & 0.01022027 & 0.010220 & 9.1875 & 0.0387\end{array}$

$\begin{array}{lll}\text { Error } & 4 & 0.00444964 \\ \text { C. Total } & 5 & 0.01466991\end{array}$ 0.001112

$\begin{array}{lll}\text { C. Total } & 5 & 0.01466991\end{array}$

Means for Oneway Anova
Level Number Mean Std Error Lower 95\% Upper 95\%

$\begin{array}{llllll}1 & 3 & 2.20510 & 0.01926 & 2.1516 & 2.2586 \\ 2 & 3 & 2.28765 & 0.01926 & 2.2342 & 2.3411\end{array}$

Std Error uses a pooled estimate of error variance 
Exhibit D5. Measured and Measured Bias-Corrected Oxide Weight Percents by Glass \# for the Glasses Prepared Using the LM Method

(100 - Batch 1; 200 - Ustd)

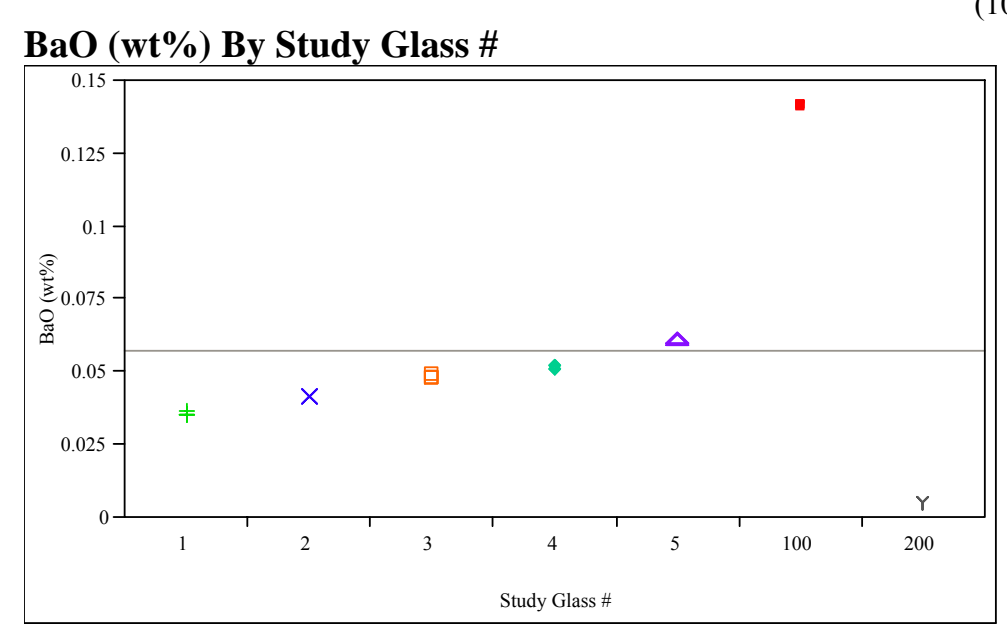

BaO bc (wt\%) By Study Glass \#

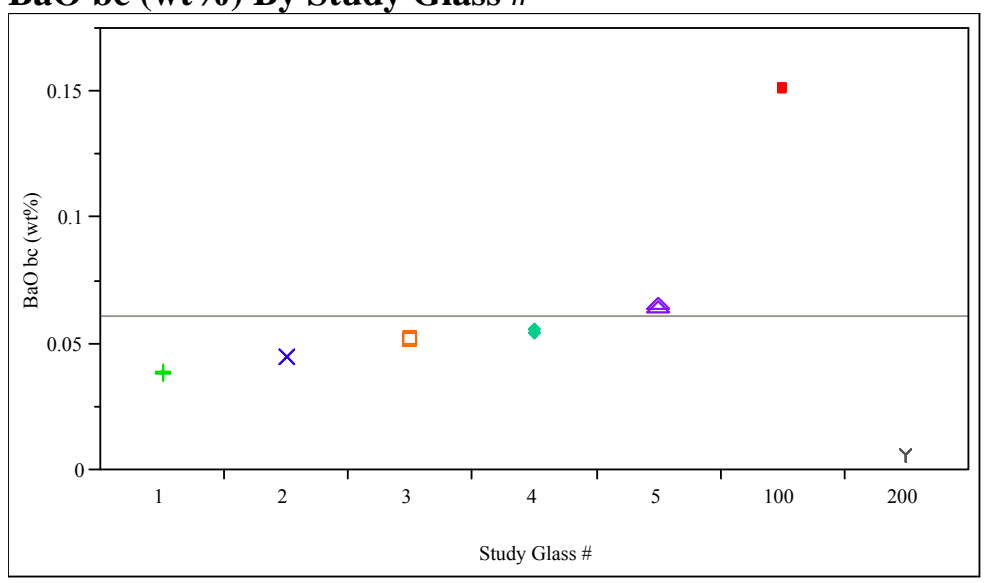

CaO (wt\%) By Study Glass \#

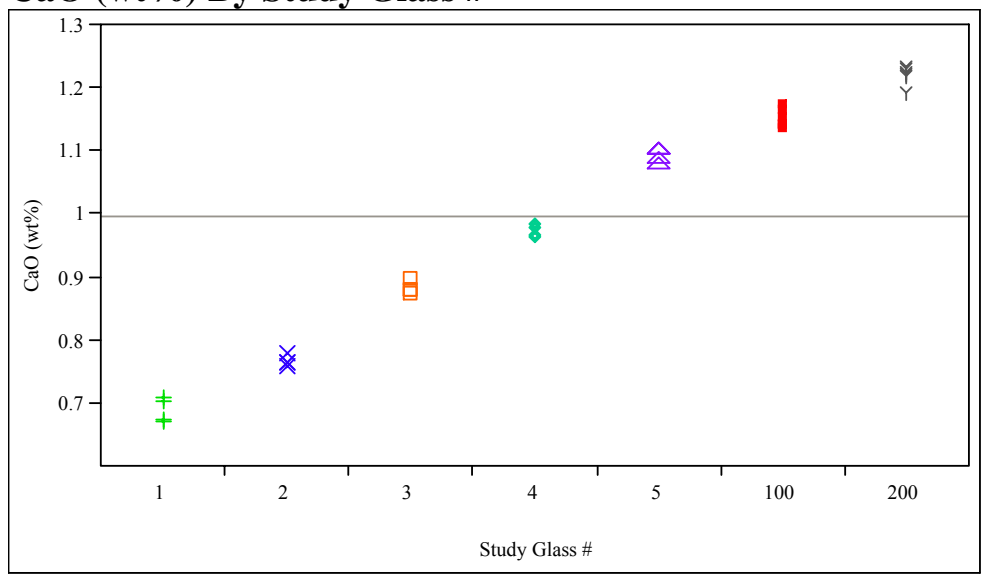

CaO bc (wt\%) By Study Glass \#

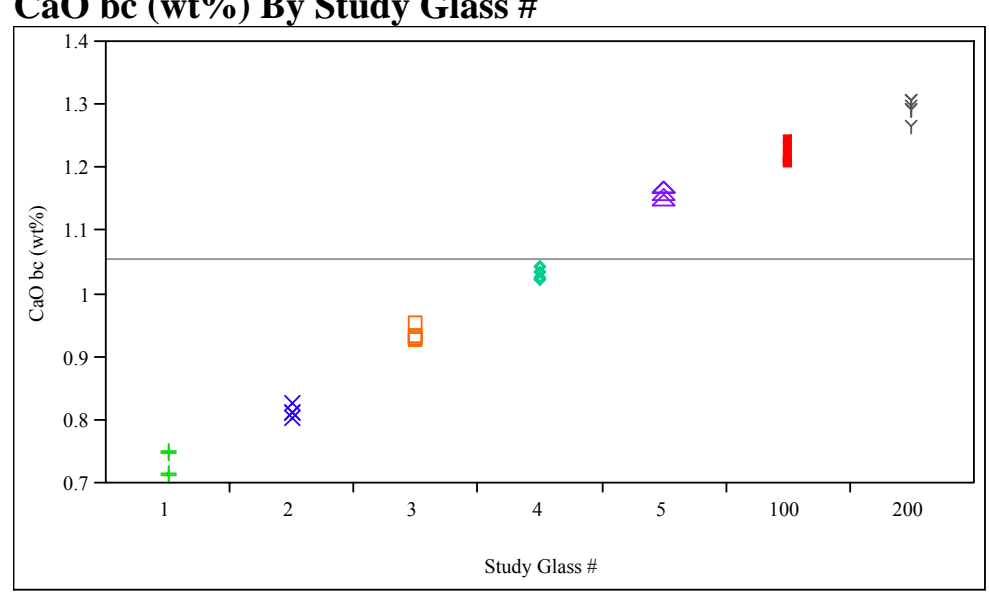


Exhibit D5. Measured and Measured Bias-Corrected Oxide Weight Percents by Glass \# for the Glasses Prepared Using the LM Method (continued)

(100 - Batch 1;200 - Ustd)

\section{Ce2O3 (wt\%) By Study Glass \#}

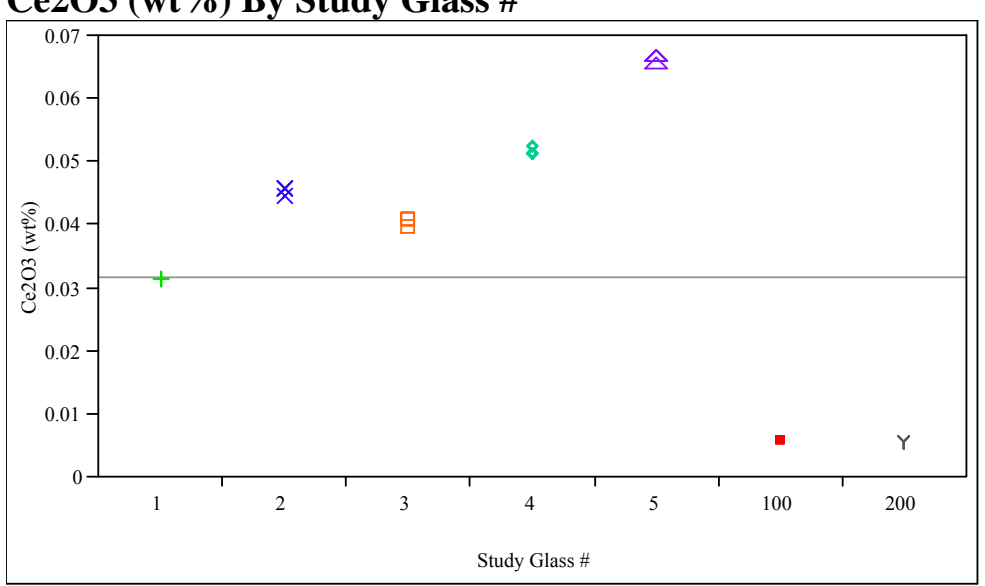

Ce2O3 bc (wt\%) By Study Glass \#

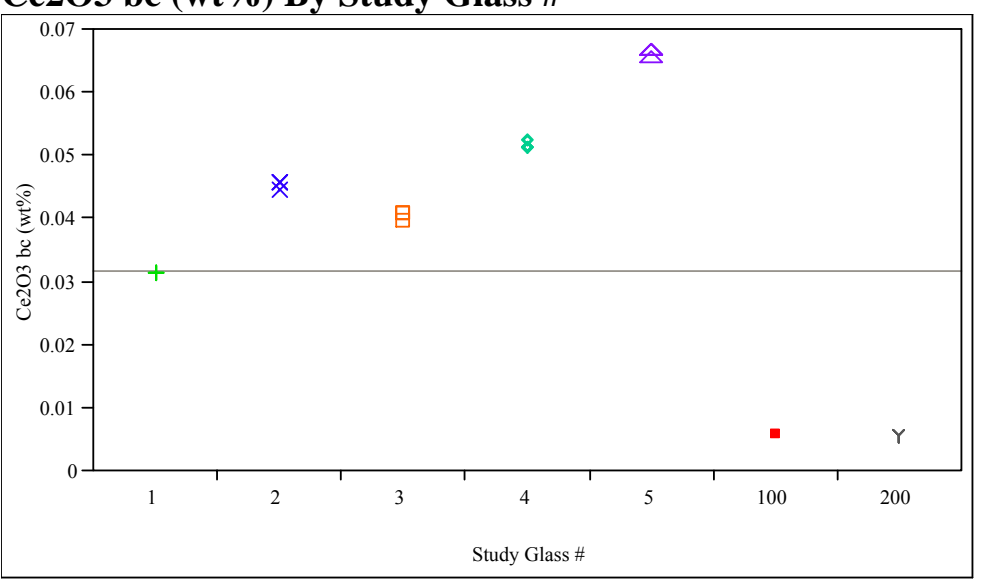

\section{Cr2O3 (wt\%) By Study Glass \#}

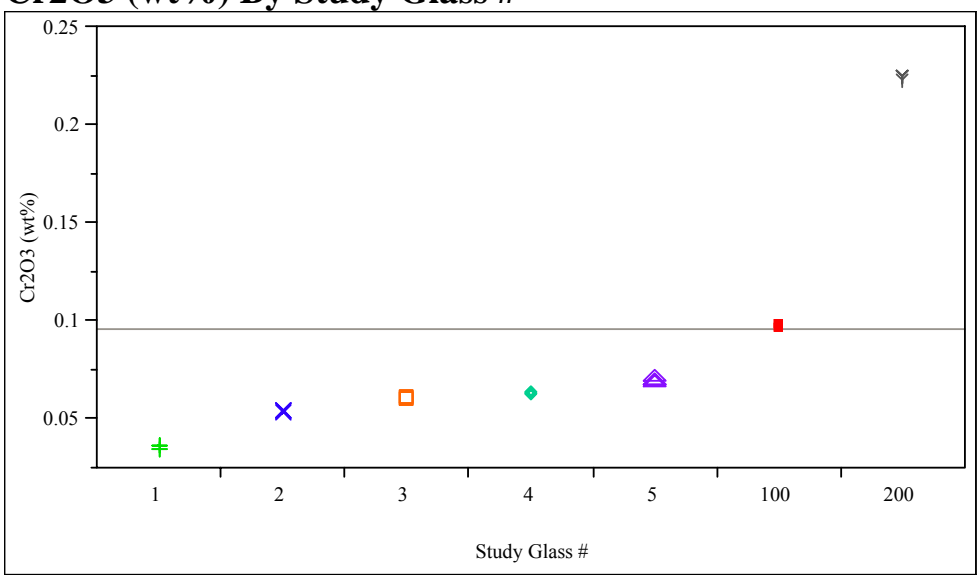

Cr2O3 bc (wt \%) By Study Glass \#

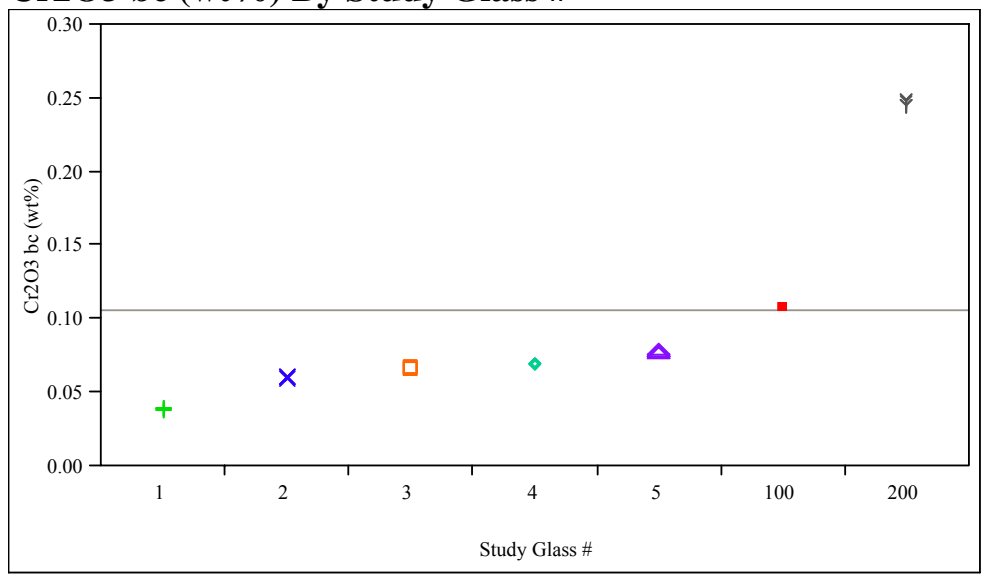


Exhibit D5. Measured and Measured Bias-Corrected Oxide Weight Percents by Glass \# for the Glasses Prepared Using the LM Method (continued)

(100 - Batch 1; 200 - Ustd)

CuO (wt\%) By Study Glass \#

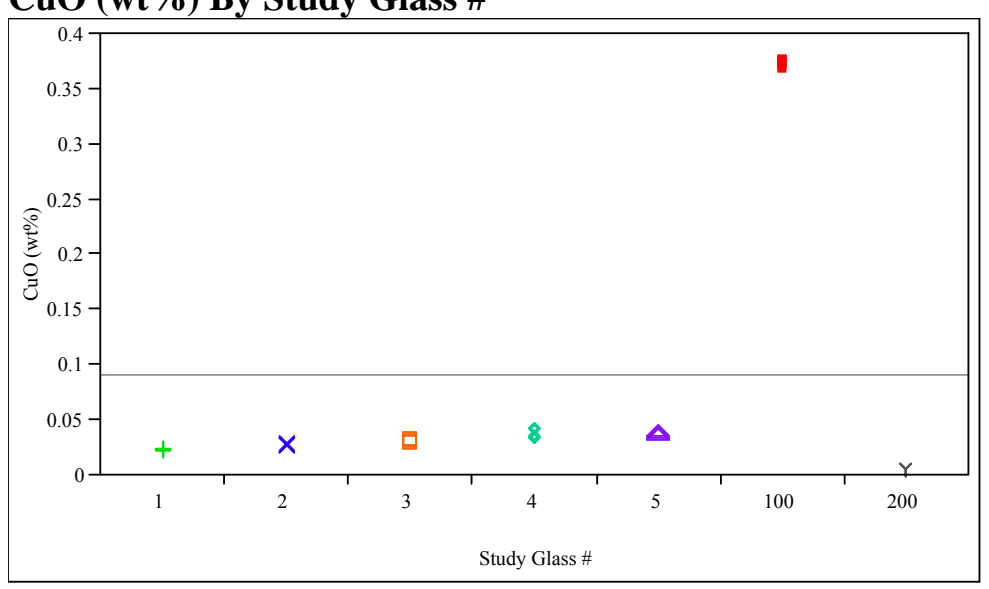

CuO bc (wt\%) By Study Glass \#

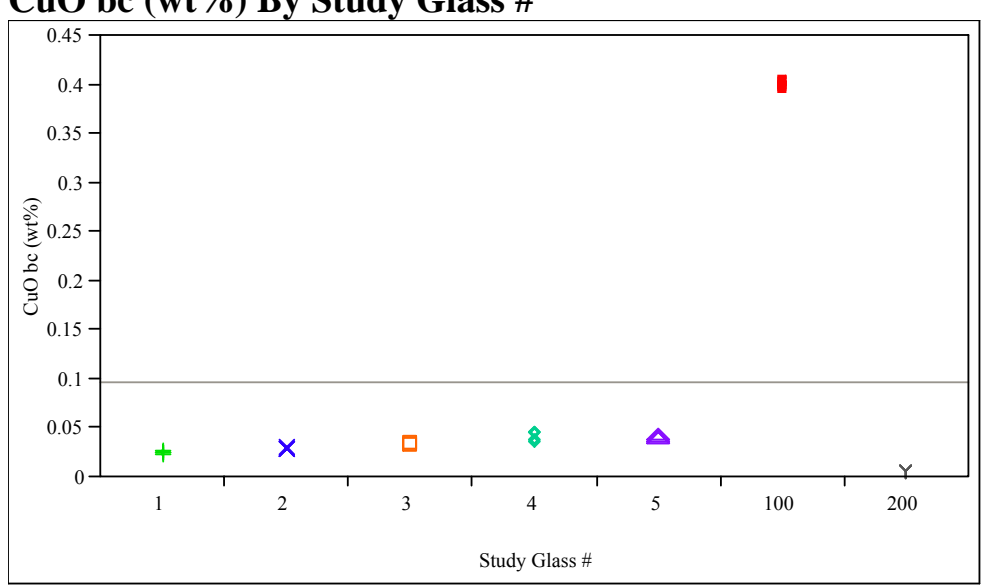

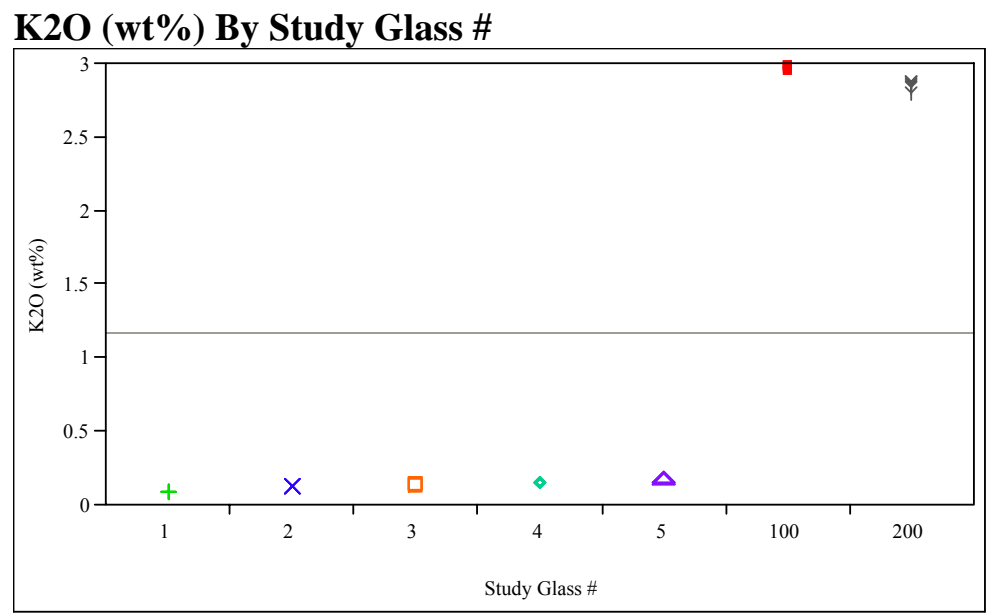

K2O bc (wt\%) By Study Glass \#

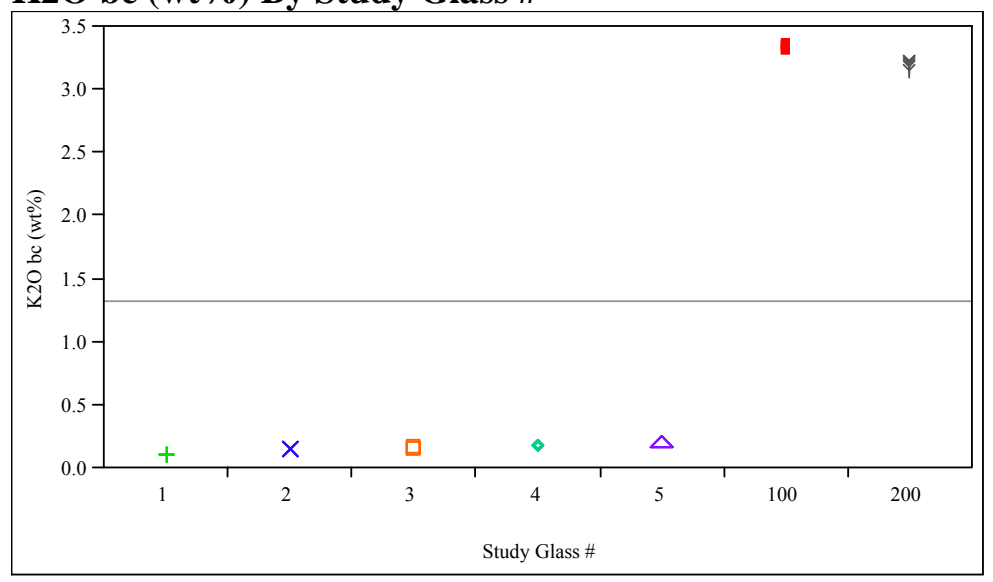


Exhibit D5. Measured and Measured Bias-Corrected Oxide Weight Percents by Glass \# for the Glasses Prepared Using the LM Method (continued)

(100 - Batch 1; 200 - Ustd)

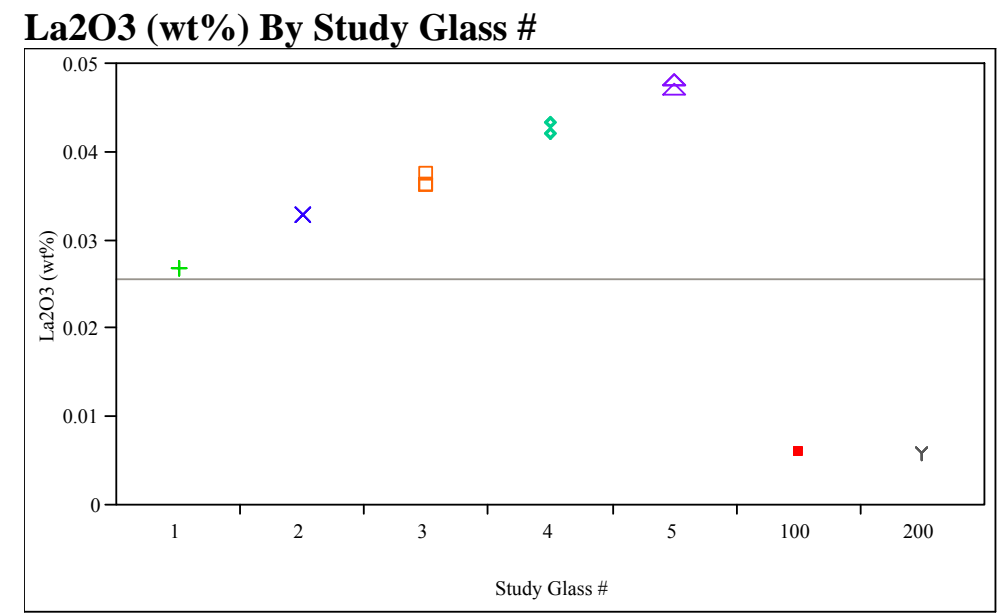

La2O3 bc (wt\%) By Study Glass \#

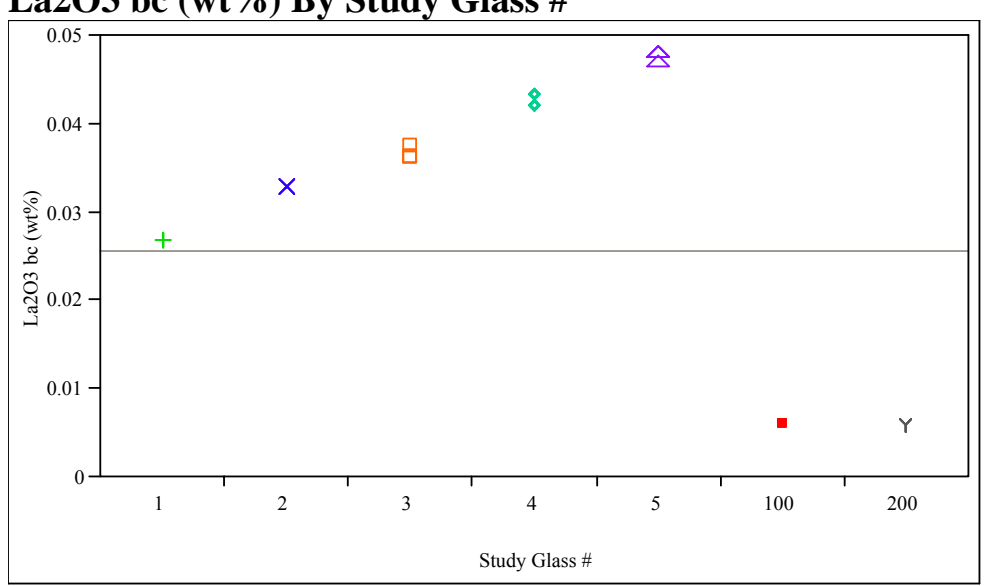

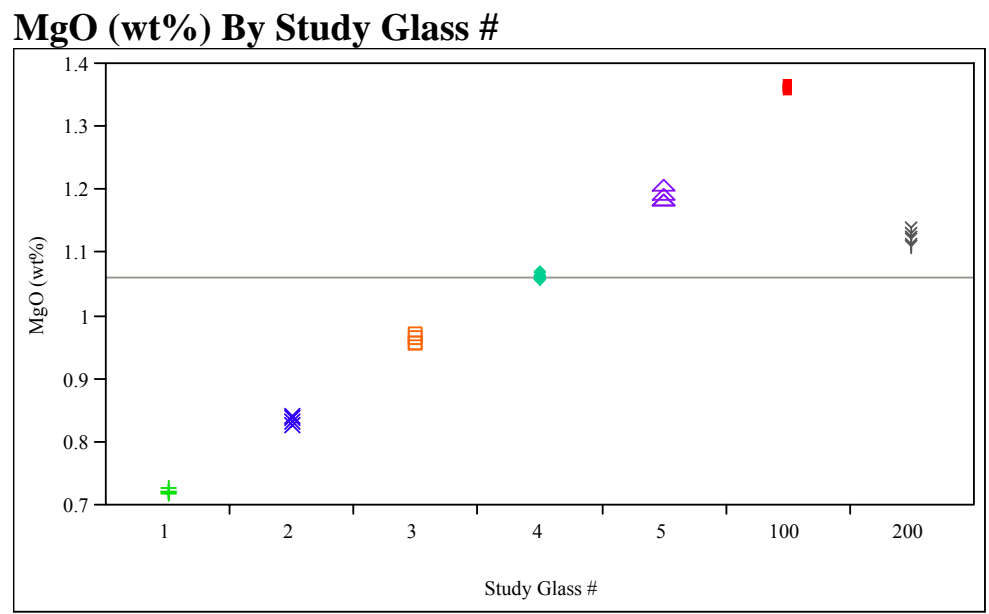

MgO bc (wt \%) By Study Glass \#

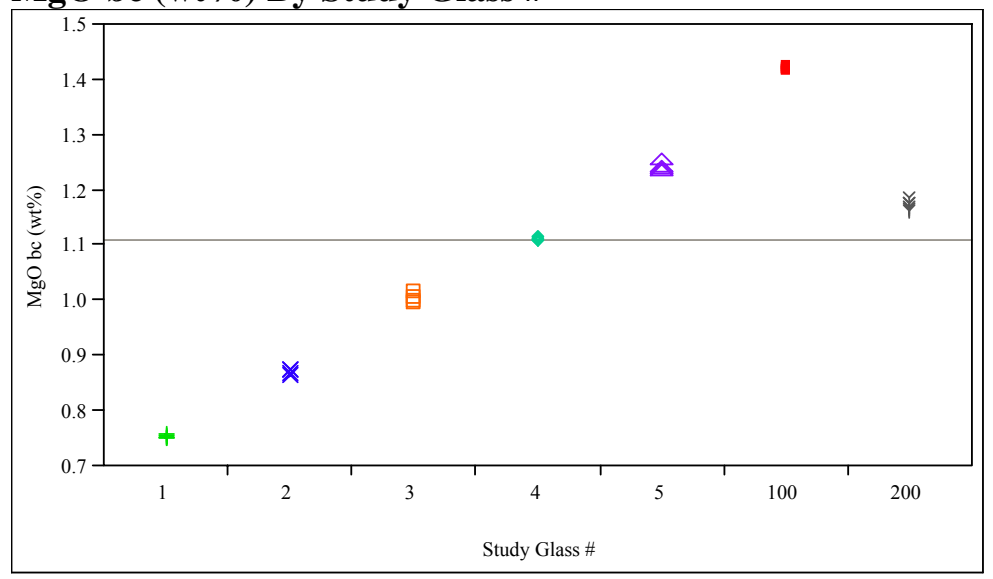


Exhibit D5. Measured and Measured Bias-Corrected Oxide Weight Percents by Glass \# for the Glasses Prepared Using the LM Method (continued)

(100 - Batch 1; 200 - Ustd)

MnO (wt \%) By Study Glass \#

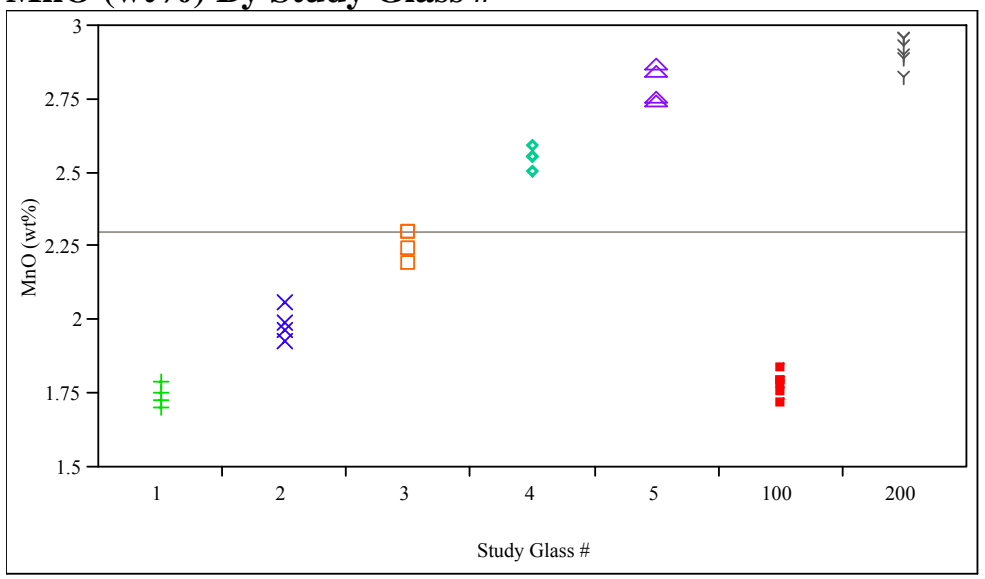

MnO bc (wt\%) By Study Glass \#

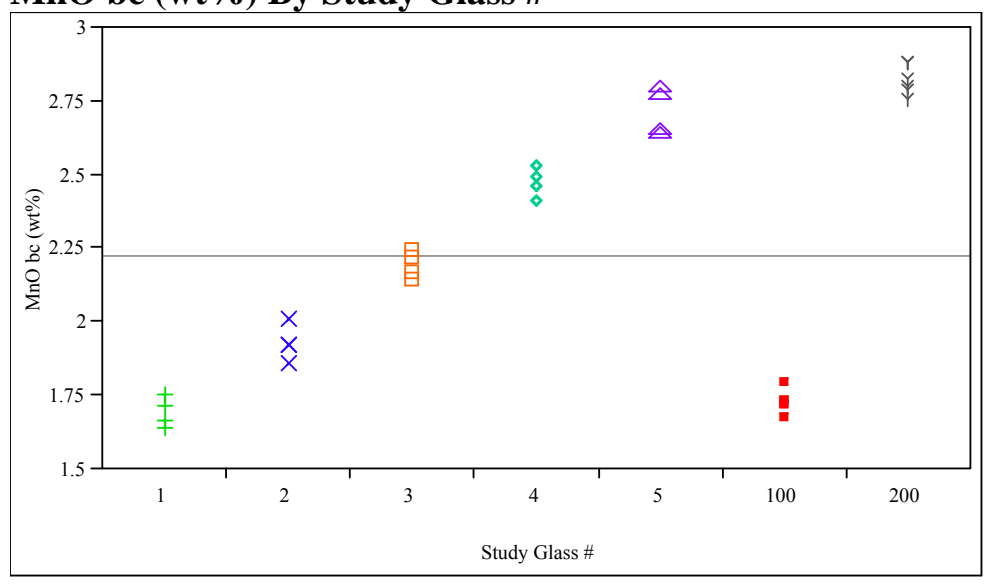

Na2O (wt\%) By Study Glass \#

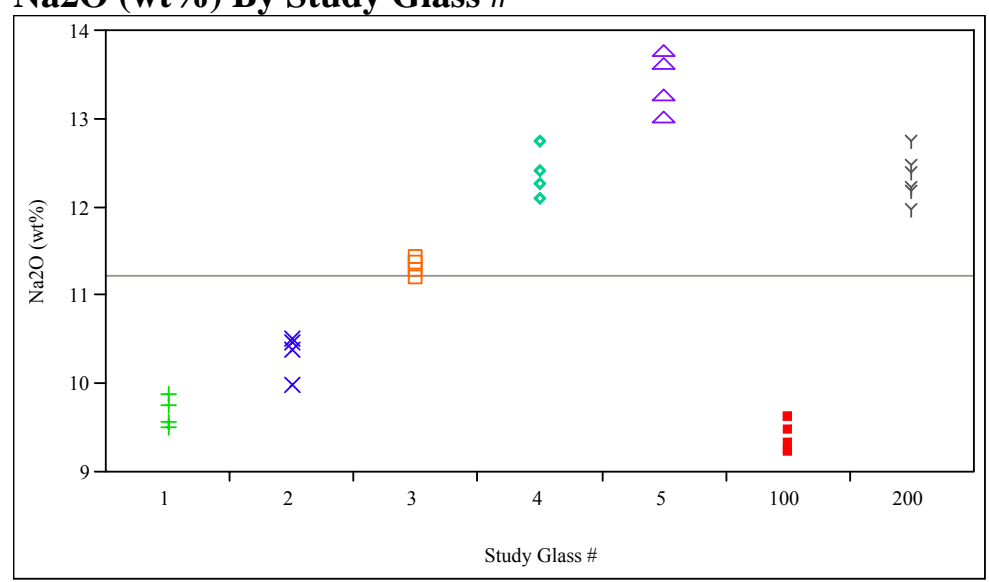

Na2O bc (wt \%) By Study Glass \#

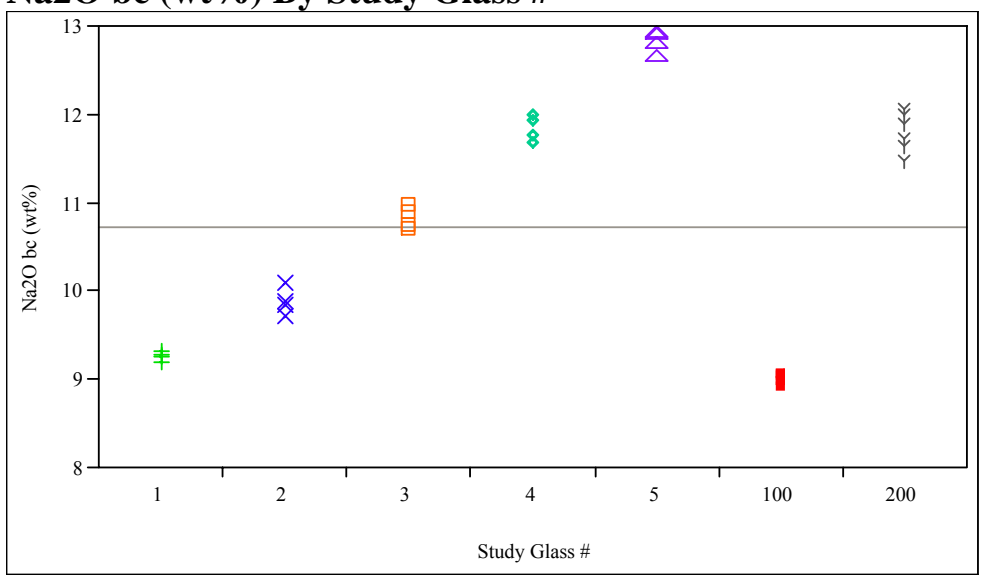


Exhibit D5. Measured and Measured Bias-Corrected Oxide Weight Percents by Glass \# for the Glasses Prepared Using the LM Method (continued)

(100 - Batch 1;200 - Ustd)

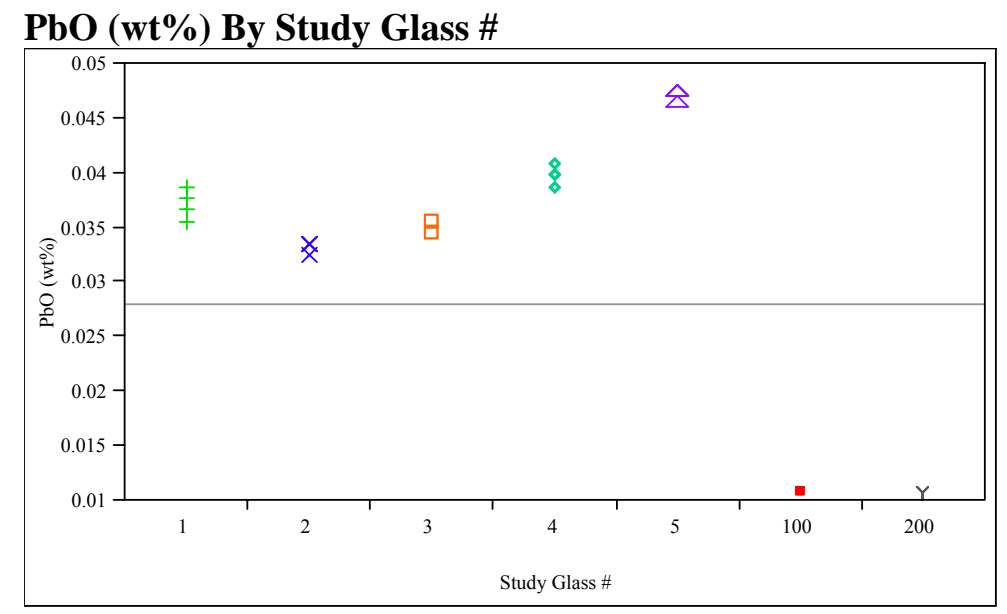

PbO bc (wt\%) By Study Glass \#

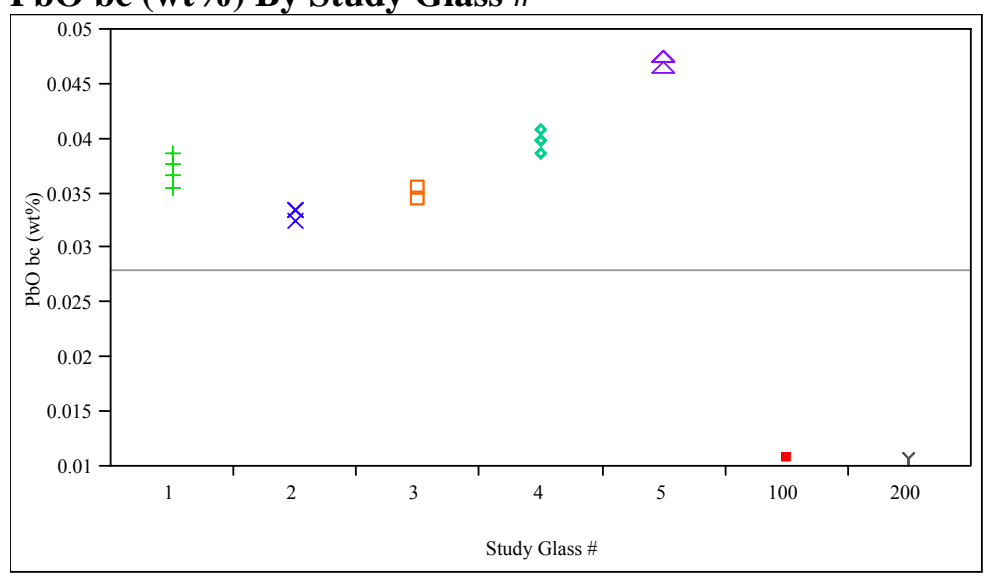

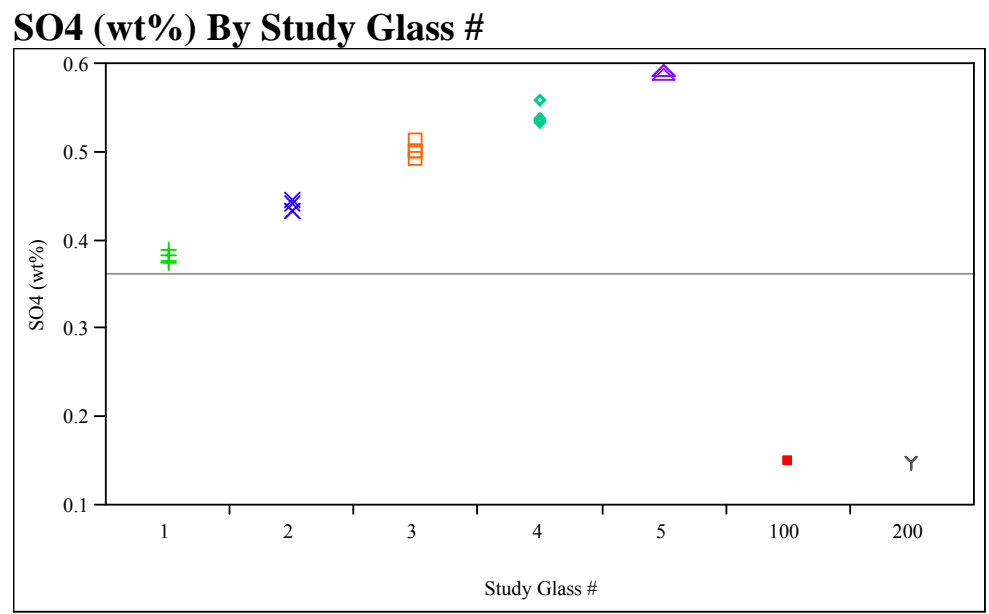

SO4 bc (wt\%) By Study Glass \#

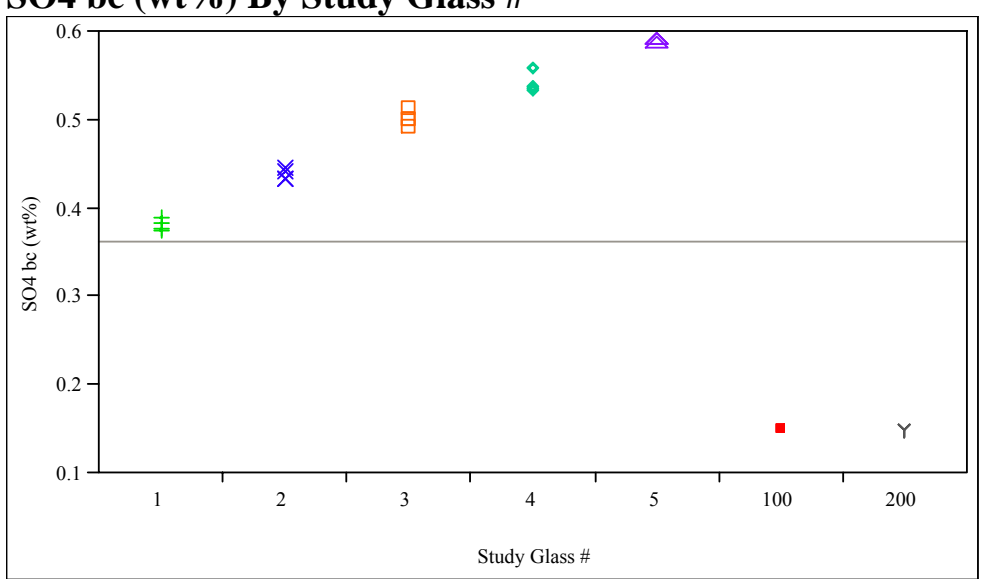


Exhibit D5. Measured and Measured Bias-Corrected Oxide Weight Percents by Glass \# for the Glasses Prepared Using the LM Method (continued)

(100 - Batch 1; 200 - Ustd)

ThO2 (wt \%) By Study Glass \#

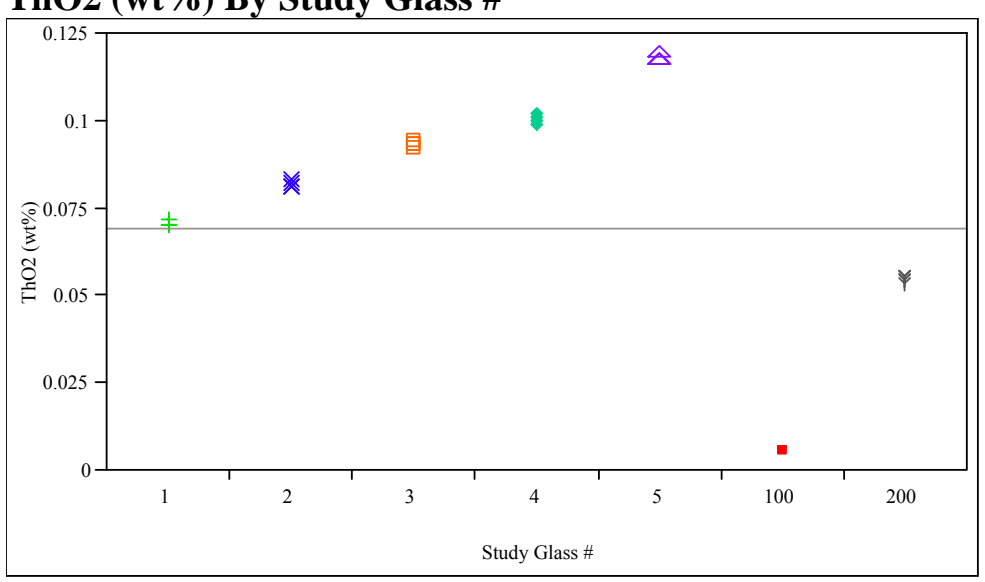

ThO2 bc (wt\%) By Study Glass \#

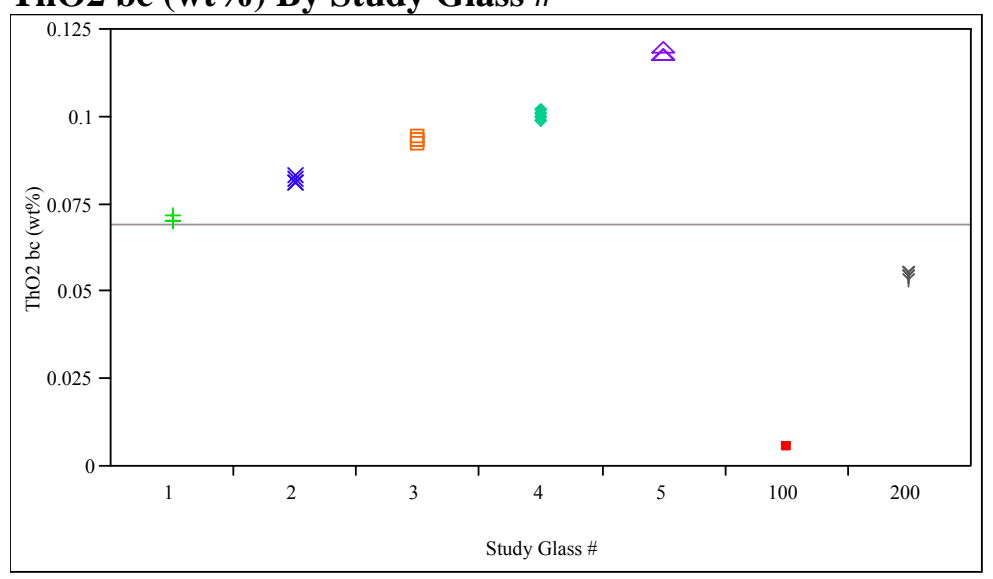

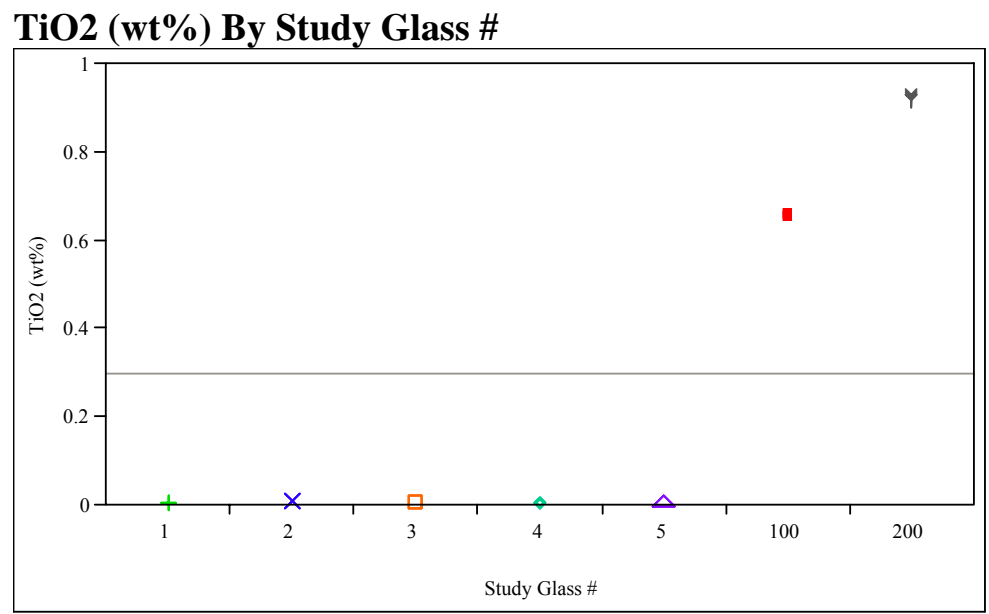

TiO2 bc (wt\%) By Study Glass \#

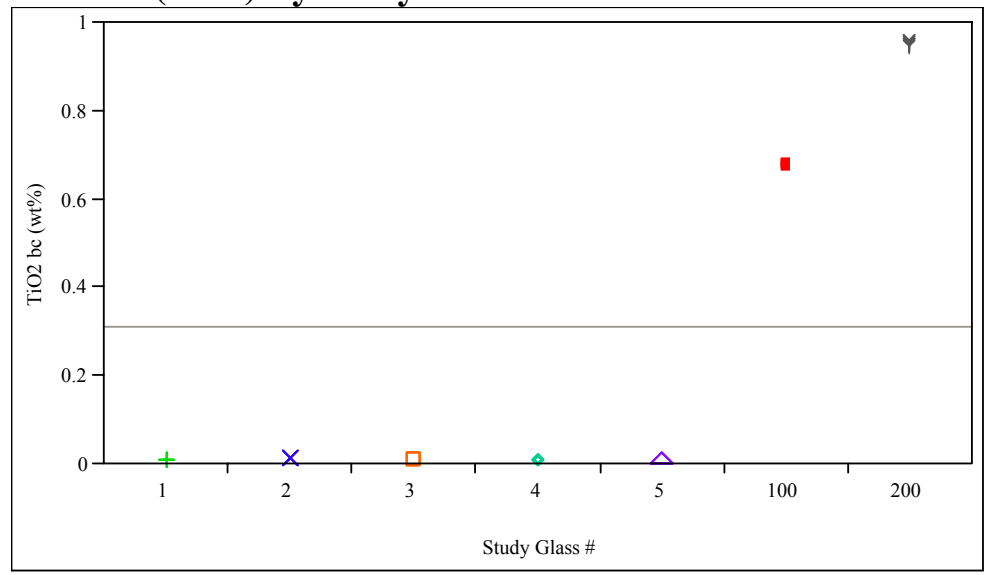


Exhibit D5. Measured and Measured Bias-Corrected Oxide Weight Percents by Glass \# for the Glasses Prepared Using the LM Method (continued)

(100 - Batch 1;200 - Ustd)

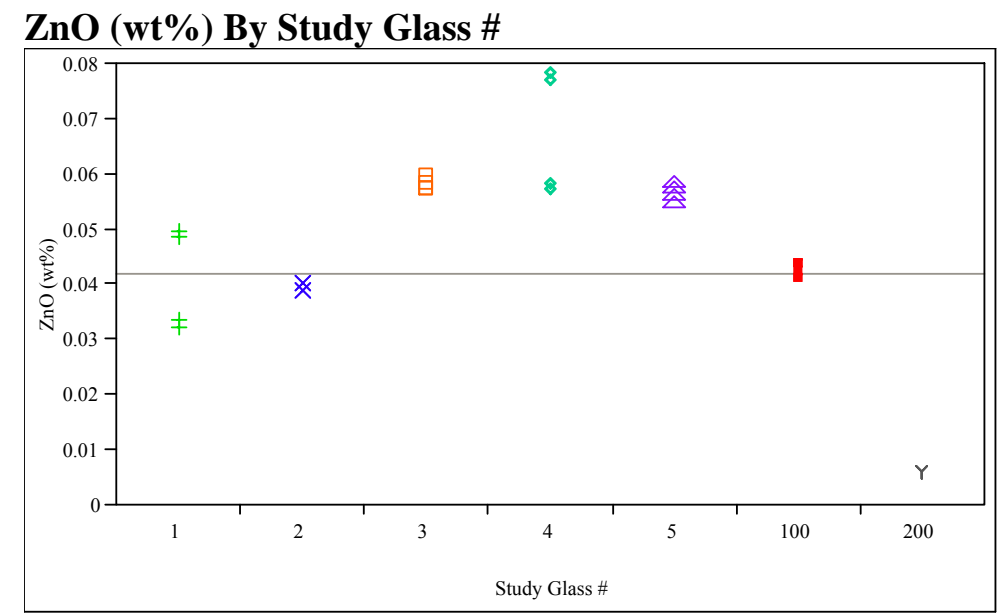

ZnO bc (wt\%) By Study Glass \#

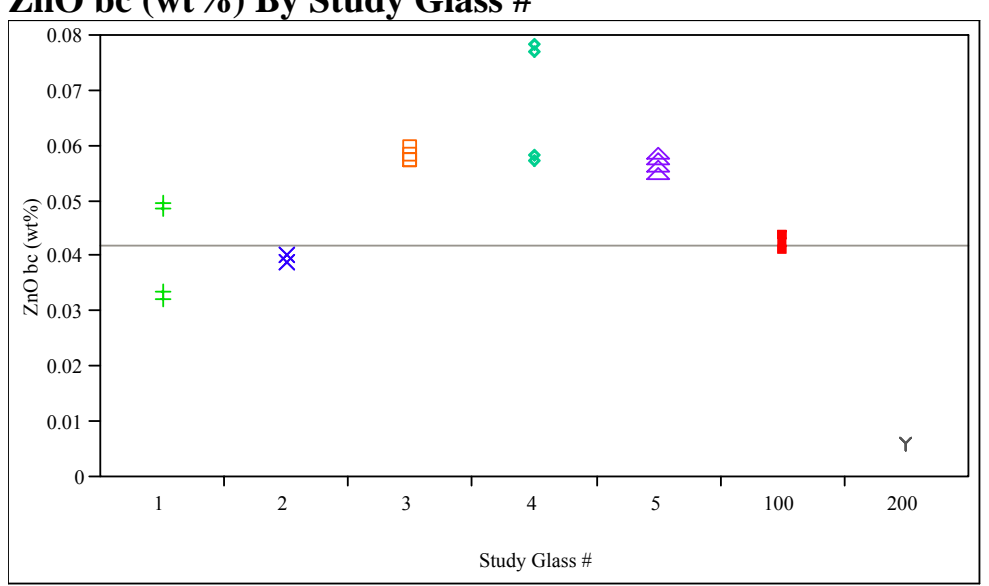

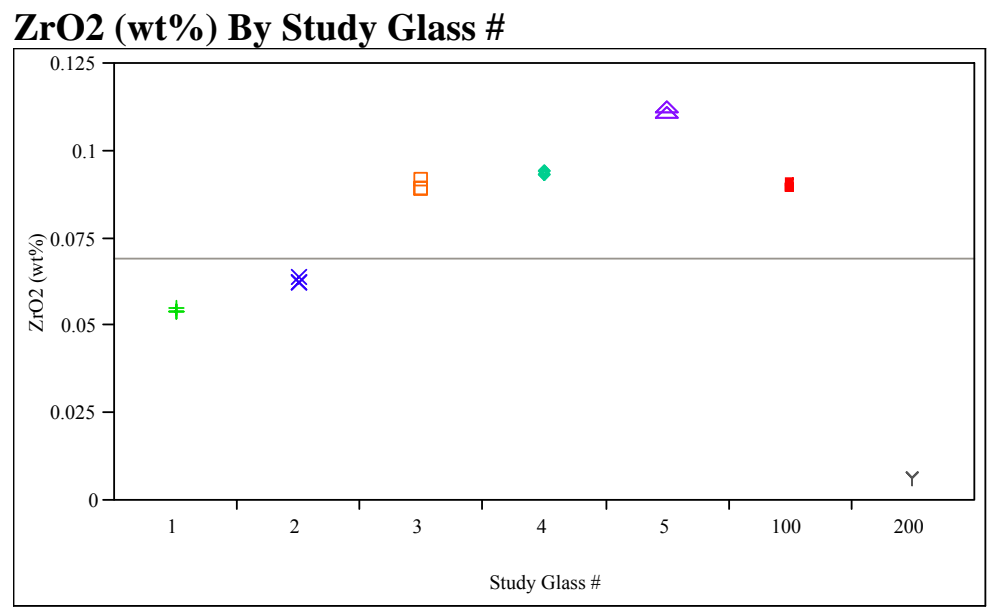

ZrO2 bc (wt\%) By Study Glass \#

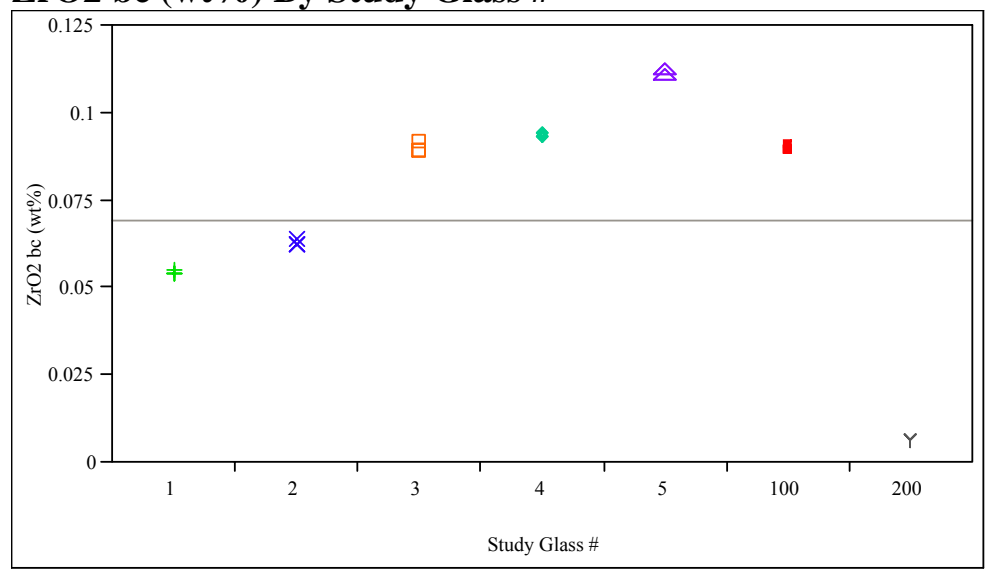




\section{Exhibit D6. Measured and Measured Bias-Corrected Oxide Weight Percent}

by Glass \# for the Glasses Prepared Using the PF Method

$(100-$ Batch $1 ; 200-$ Ustd $)$

\section{Al2O3 (wt \%) By Glass \#}

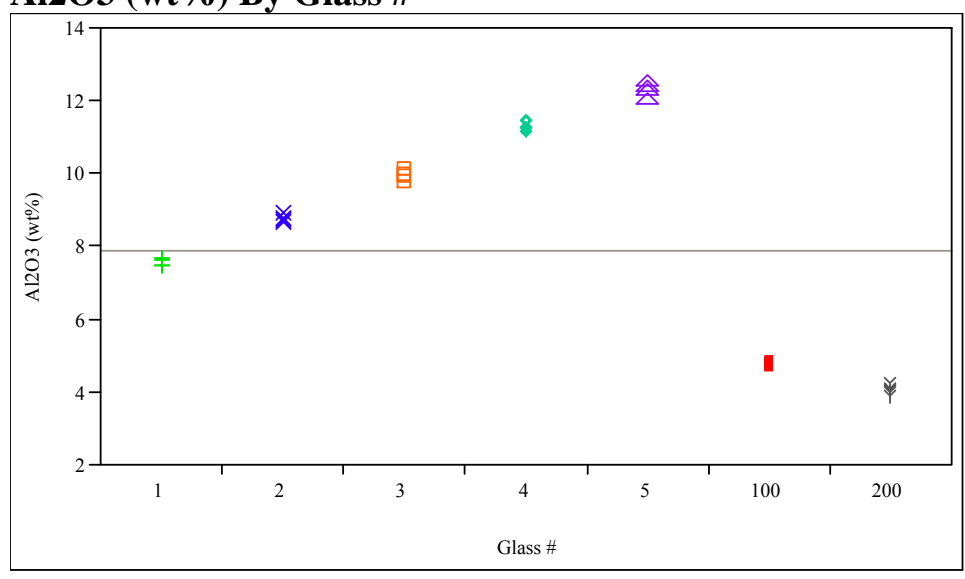

Al2O3 bc (wt \%) By Glass \#

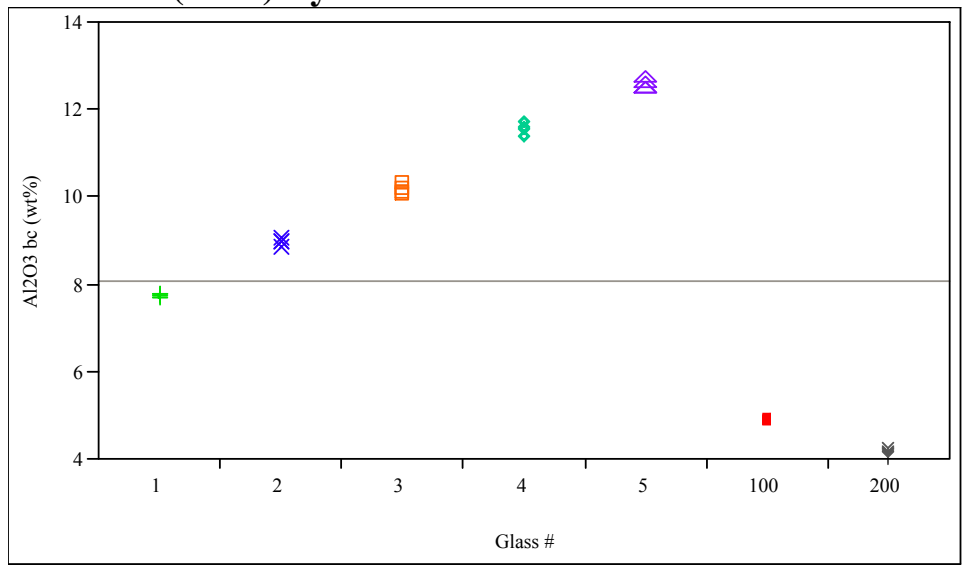

B2O3 (wt \%) By Glass \#

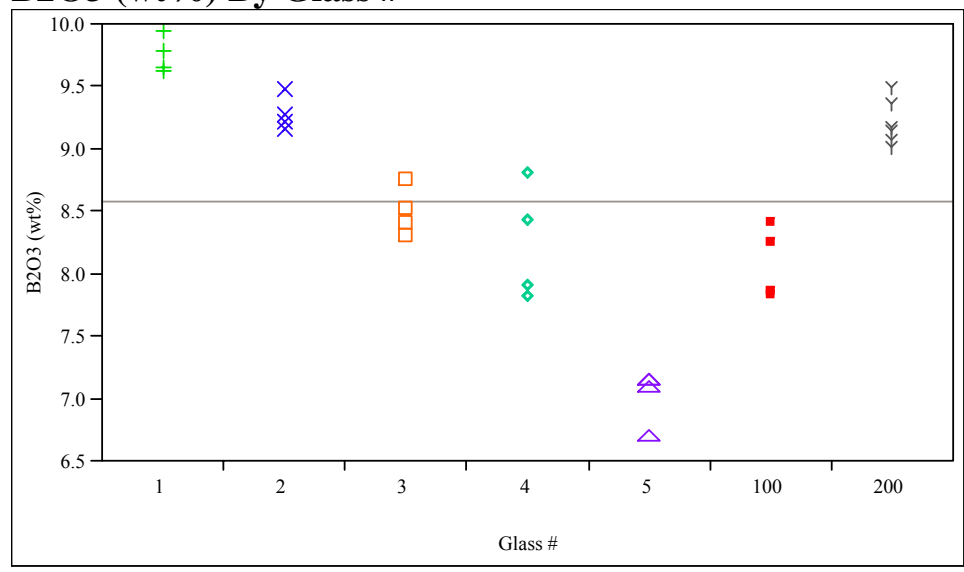

B2O3 bc (wt\%) By Glass \#

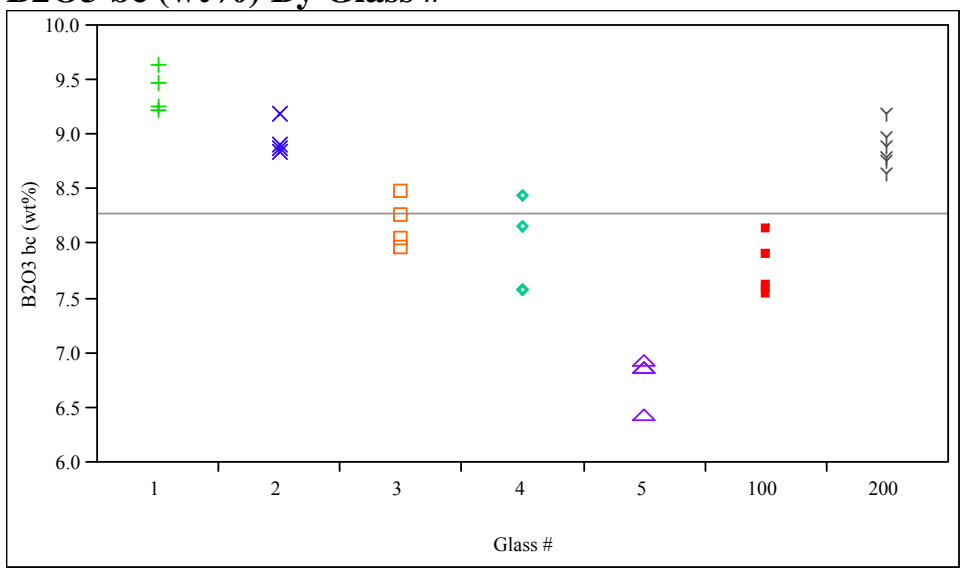




\section{Exhibit D6. Measured and Measured Bias-Corrected Oxide Weight Percent} by Glass \# for the Glasses Prepared Using the PF Method (continued)

(100 - Batch 1;200 - Ustd)
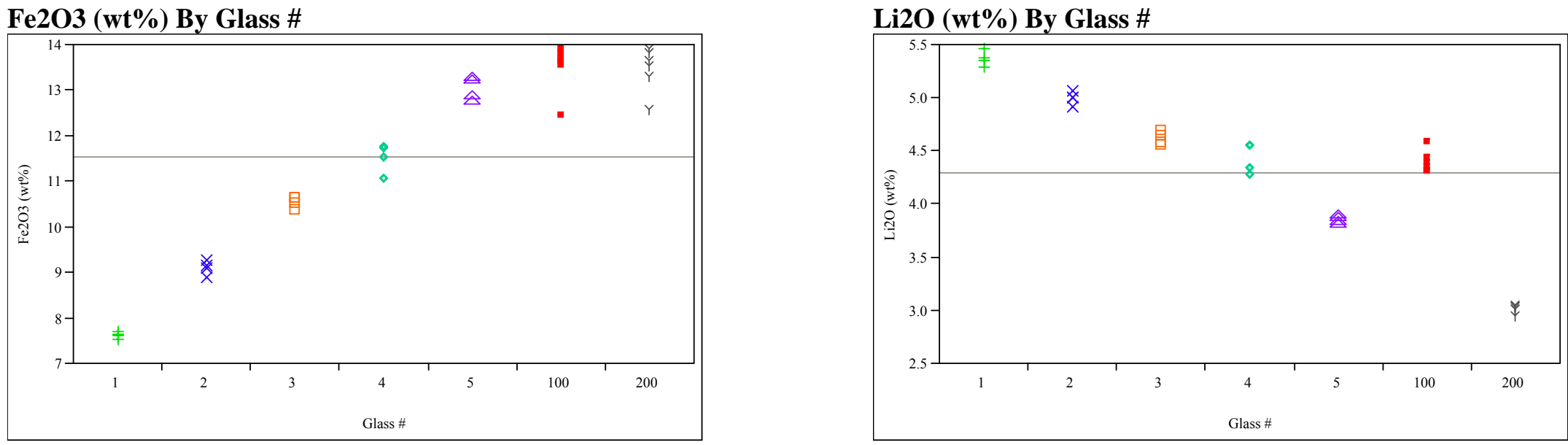

\section{Fe2O3 bc (wt \%) By Glass \#}

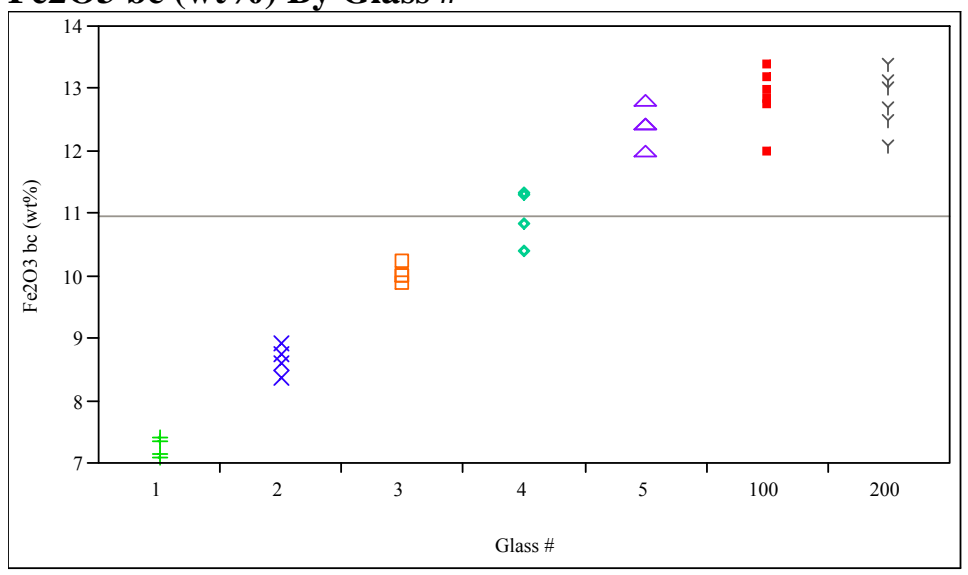

Li2O bc (wt\%) By Glass \#

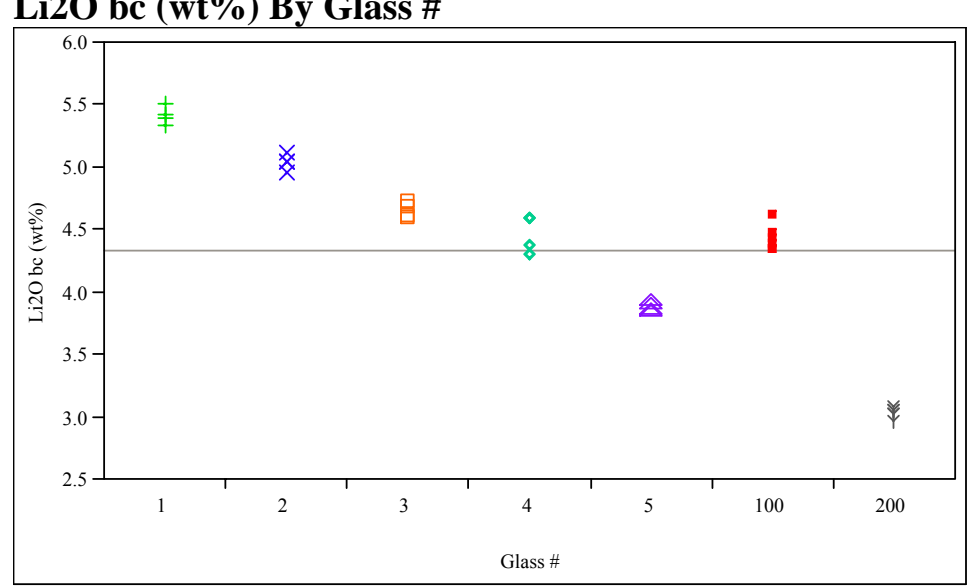




\section{Exhibit D6. Measured and Measured Bias-Corrected Oxide Weight Percent} by Glass \# for the Glasses Prepared Using the PF Method (continued)

(100 - Batch 1;200 - Ustd)
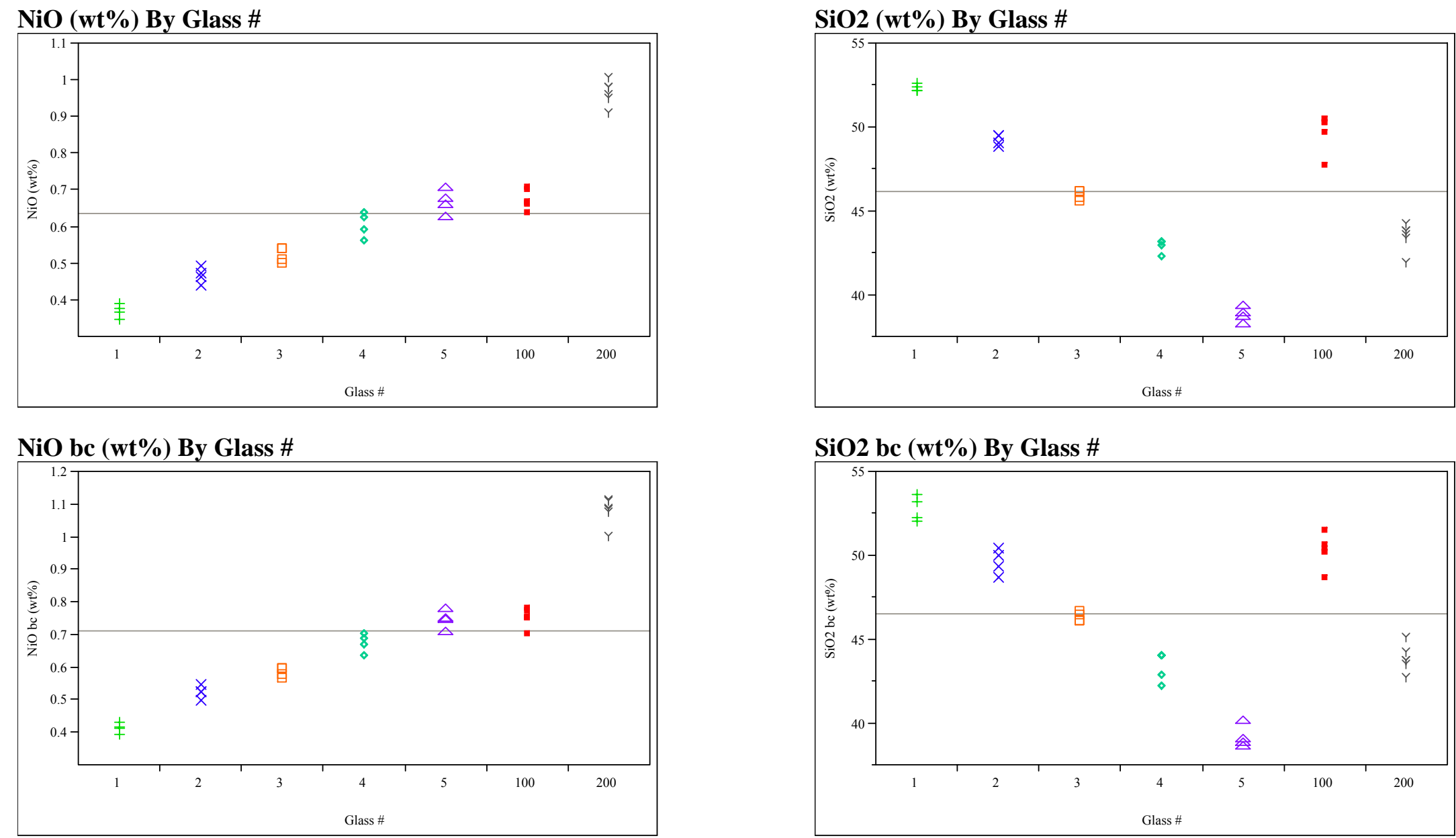


\section{Exhibit D6. Measured and Measured Bias-Corrected Oxide Weight Percent} by Glass \# for the Glasses Prepared Using the PF Method (continued)

(100 - Batch 1;200 - Ustd)

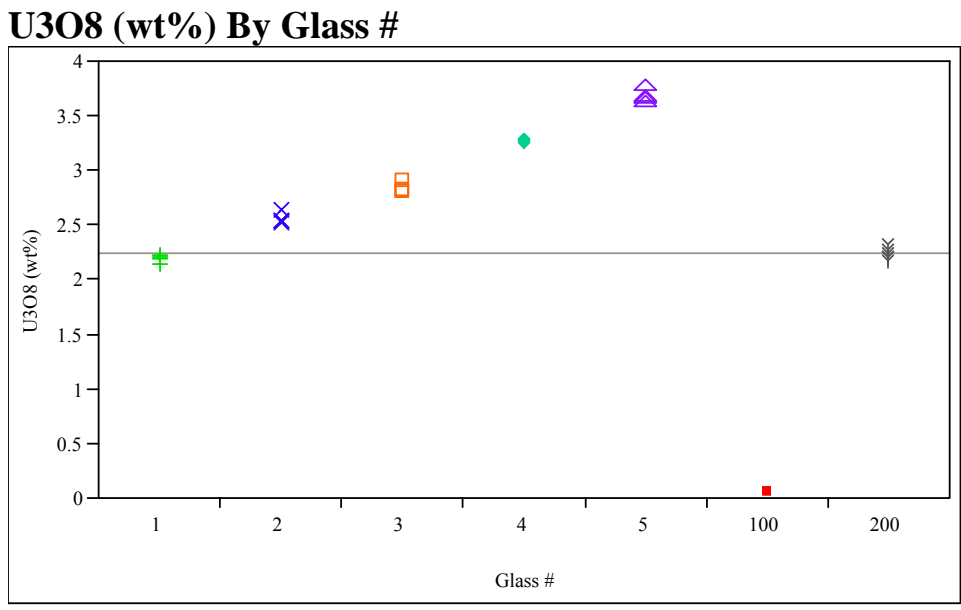

U308 bc (wt\%) By Glass \#

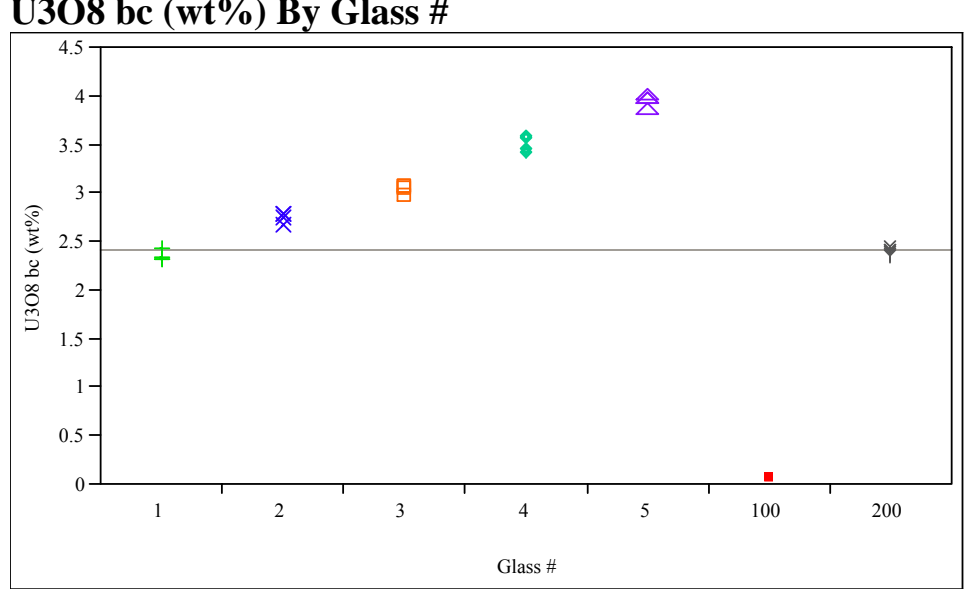




\section{Exhibit D7. Average Measured and Bias-Corrected (bc) Versus} Targeted Compositions by Glass \# by Oxide

(100 - Batch 1;200 - Ustd)
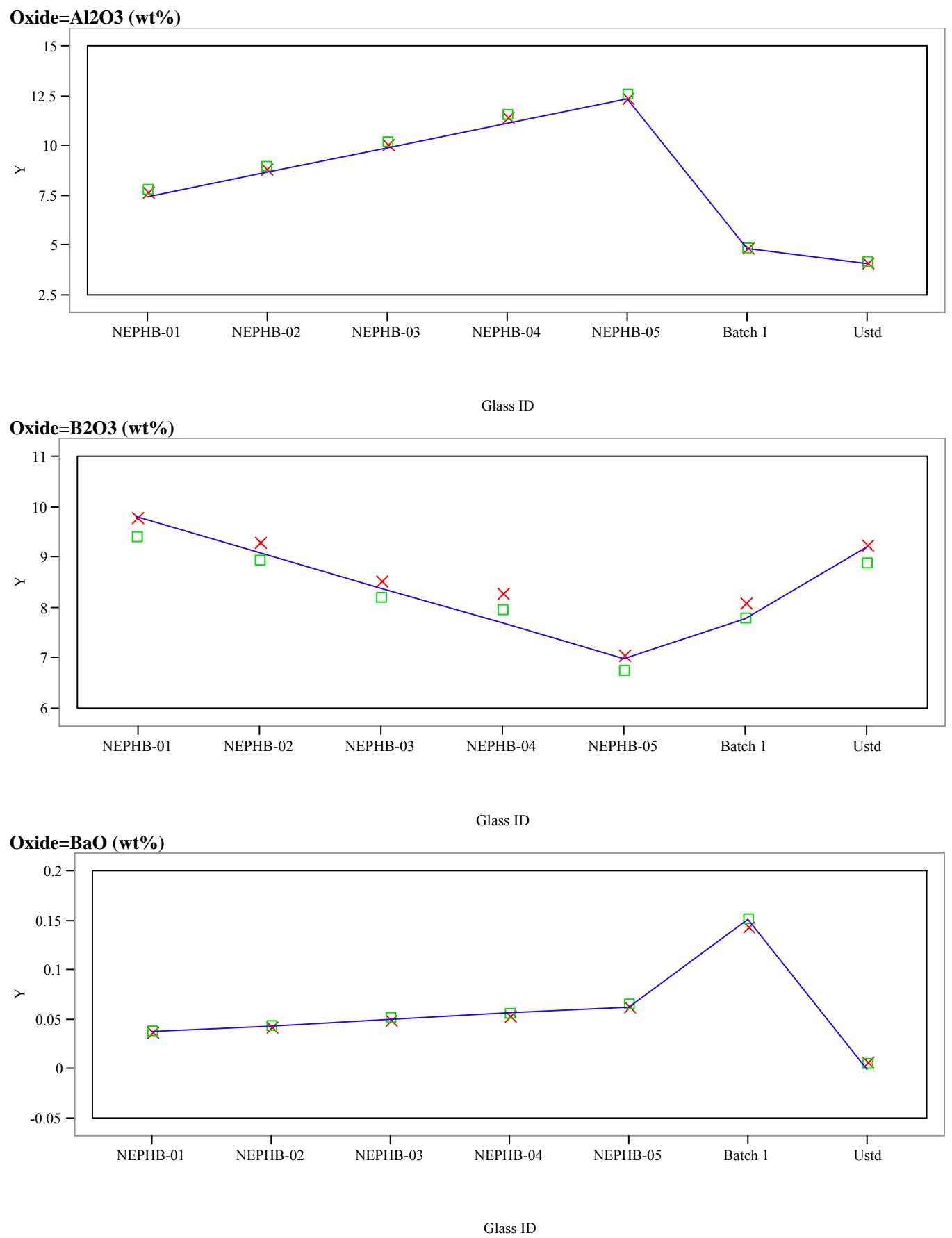

$\mathrm{Y} \times$ Measured $\square$ Measured bc $\quad$ Targeted 


\section{Exhibit D7. Average Measured and Bias-Corrected (bc) Versus Targeted Compositions by Glass \# by Oxide (continued)}

(100 - Batch 1; 200 - Ustd)
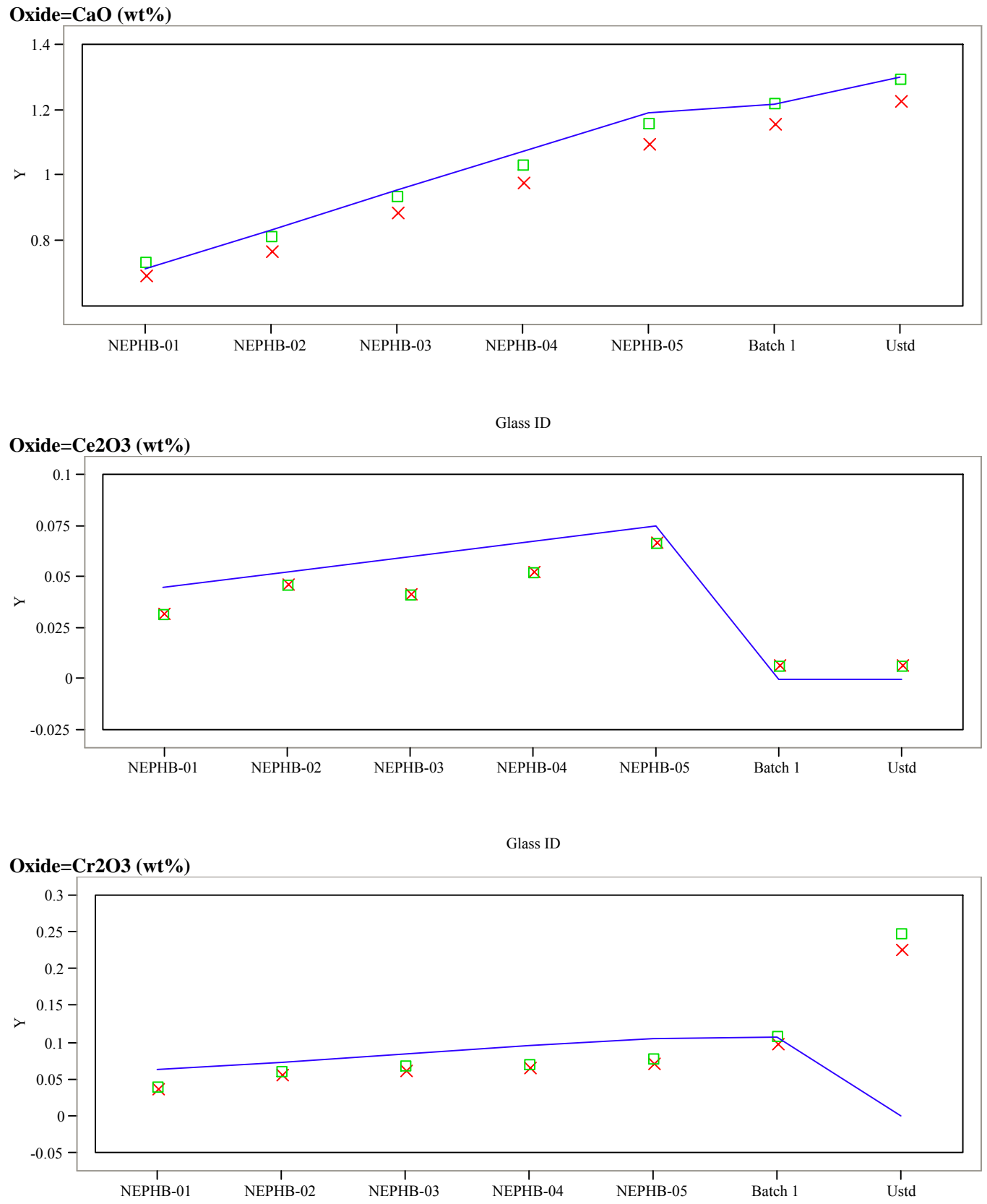

Glass ID
Y $\times$ Measured
- Measured bc 一 Targeted 


\section{Exhibit D7. Average Measured and Bias-Corrected (bc) Versus} Targeted Compositions by Glass \# by Oxide (continued)

(100 - Batch 1;200 - Ustd)
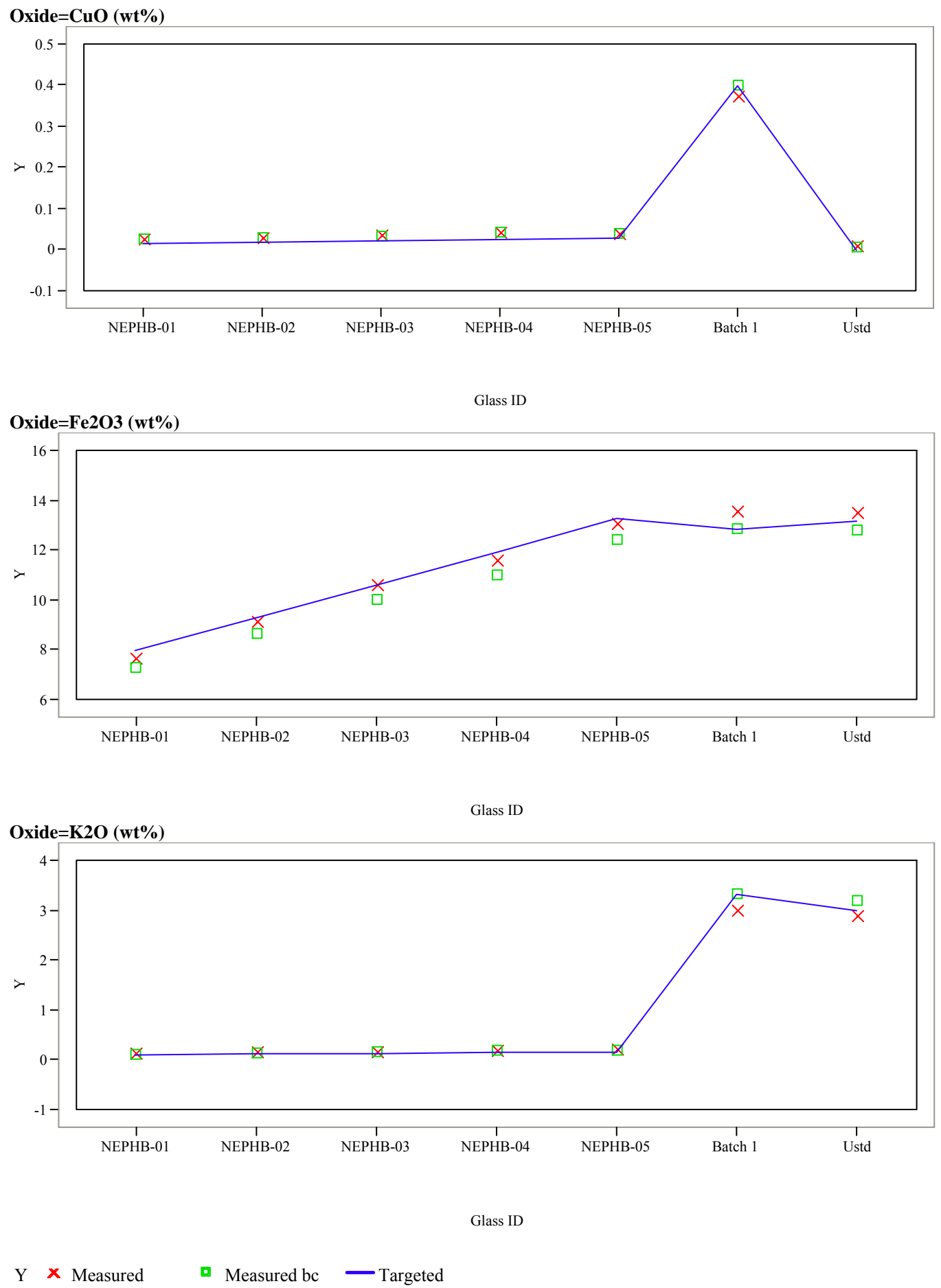


\section{Exhibit D7. Average Measured and Bias-Corrected (bc) Versus} Targeted Compositions by Glass \# by Oxide (continued)

(100 - Batch 1; 200 - Ustd)
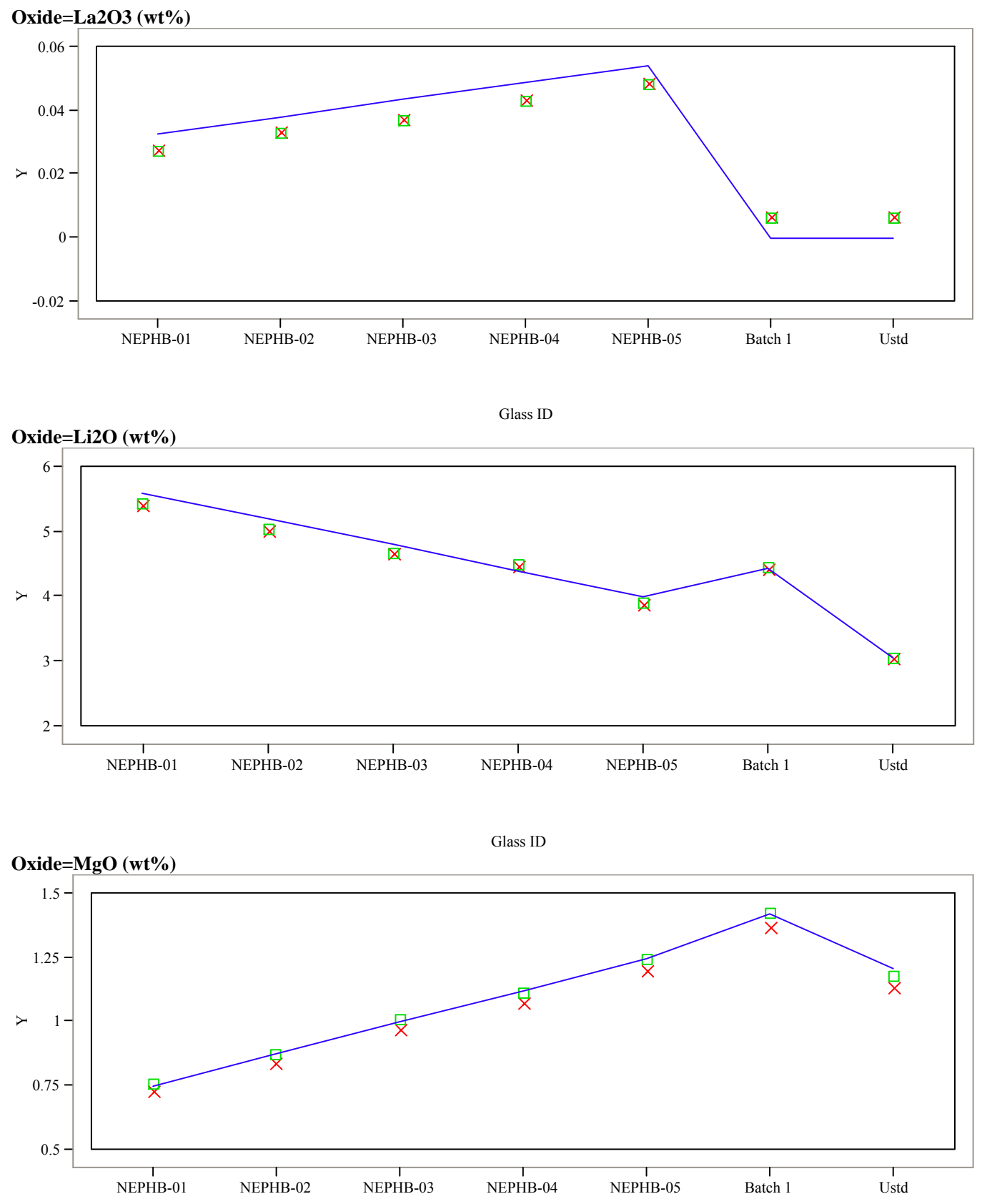

Glass ID
Y $\times$ Measured
- Measured bc — Targeted 


\section{Exhibit D7. Average Measured and Bias-Corrected (bc) Versus Targeted Compositions by Glass \# by Oxide (continued)}

(100- Batch 1;200 - Ustd)
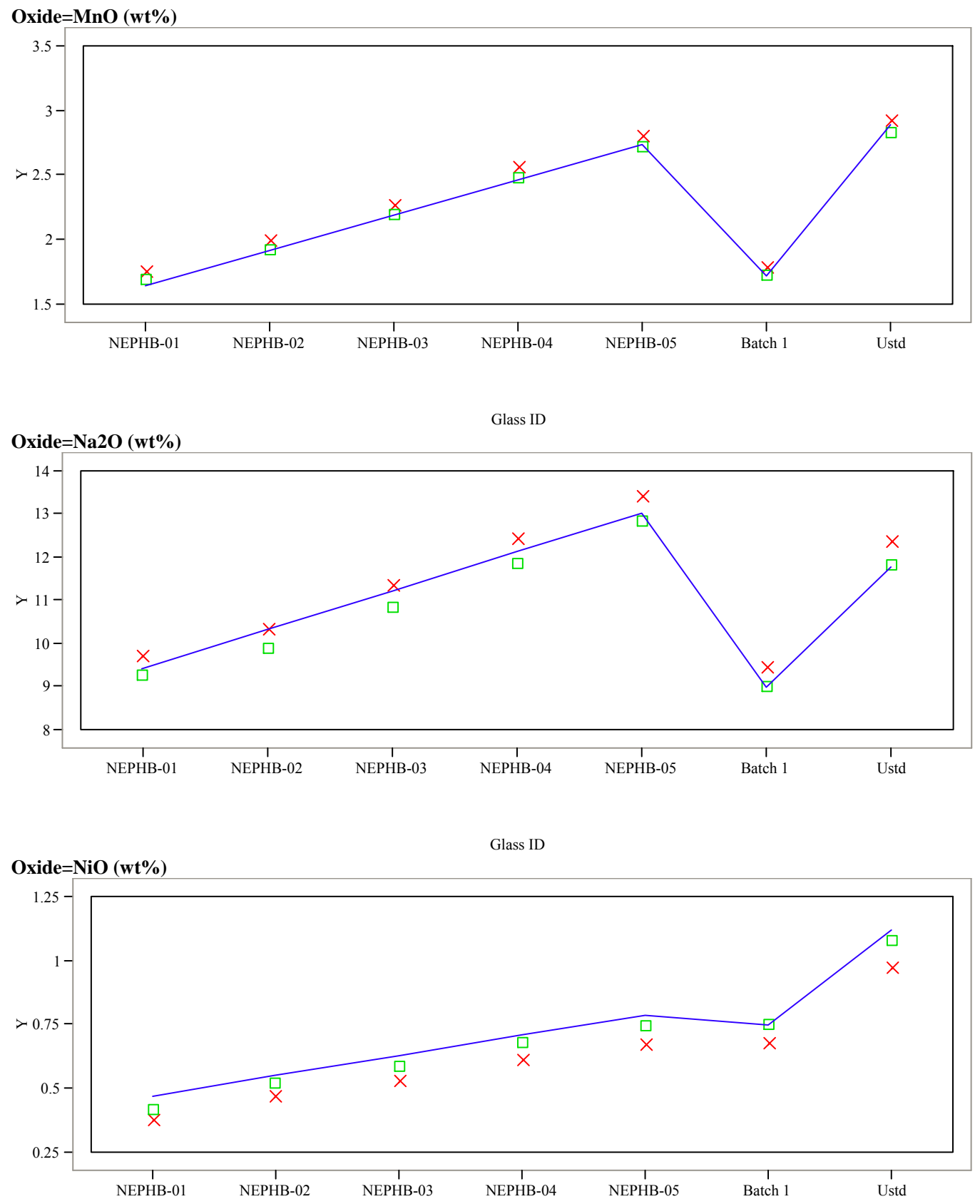

Glass ID

$\mathrm{Y} \times$ Measured $\square$ Measured bc $\quad$ Targeted 


\section{Exhibit D7. Average Measured and Bias-Corrected (bc) Versus} Targeted Compositions by Glass \# by Oxide (continued)

(100 - Batch 1; 200 - Ustd)
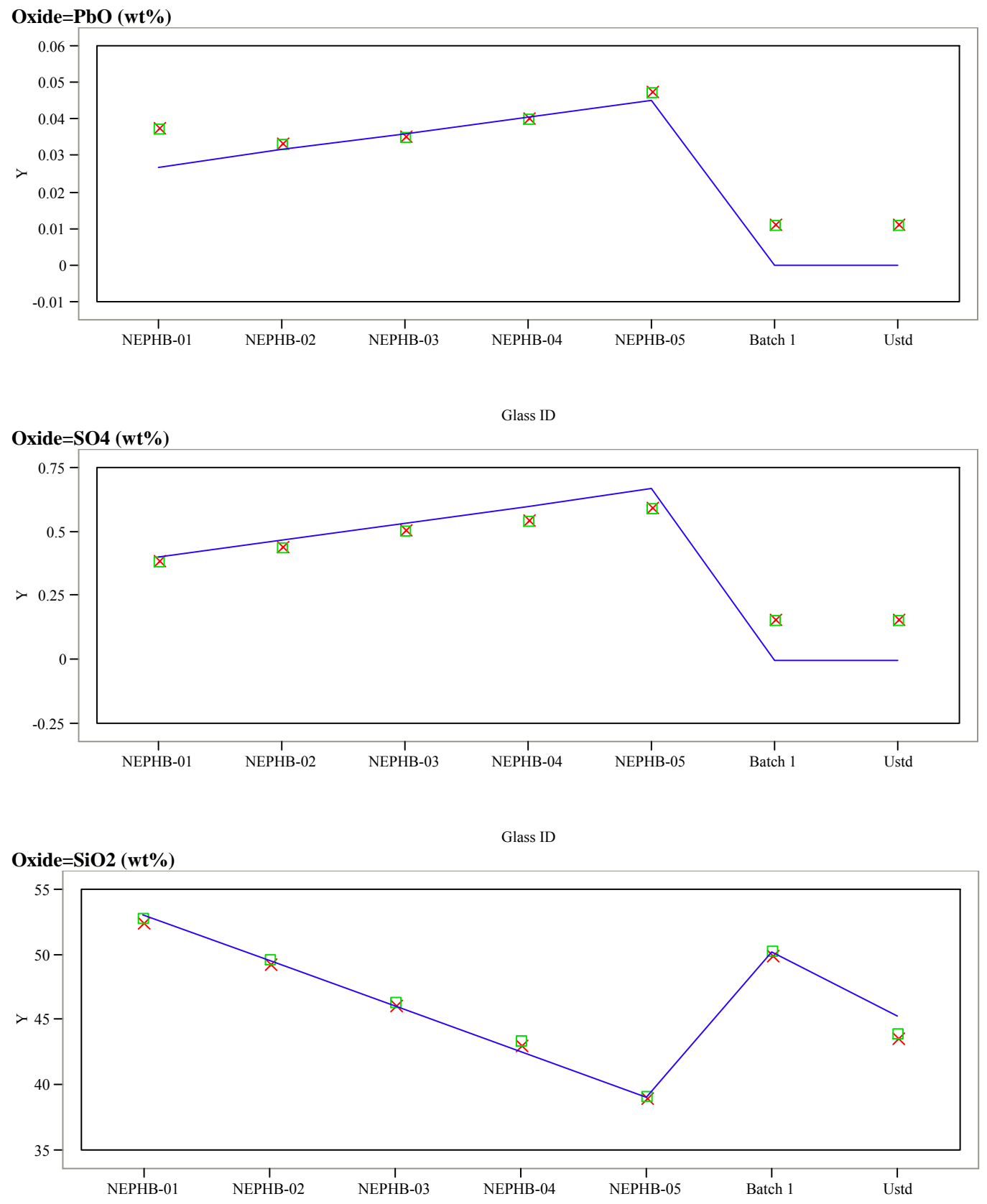

Glass ID

Y $\times$ Measured

- Measured bc — Targeted 


\section{Exhibit D7. Average Measured and Bias-Corrected (bc) Versus} Targeted Compositions by Glass \# by Oxide (continued)

(100 - Batch 1; 200 - Ustd)
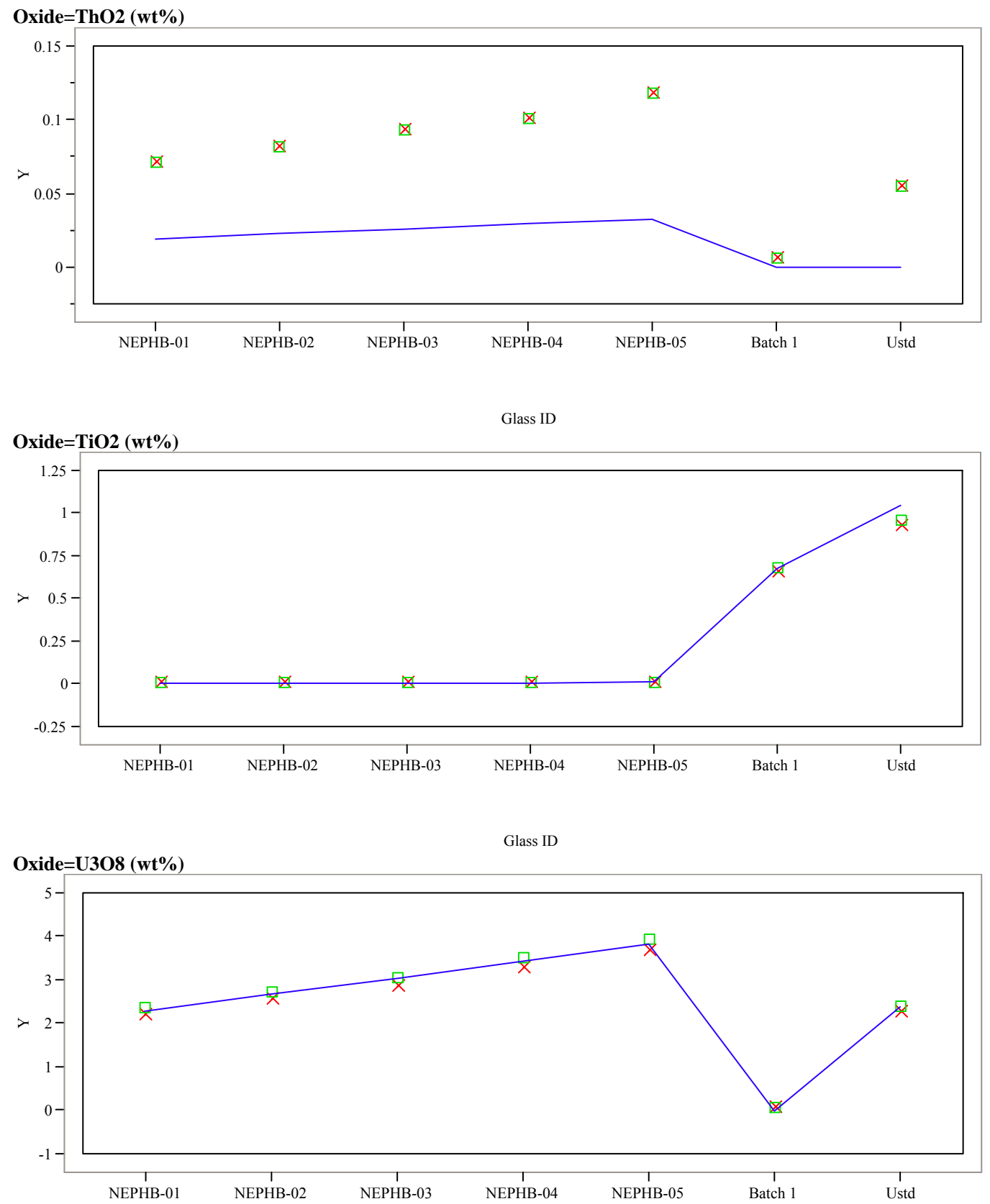

Glass ID
Y X Measured
- Measured bc — Targeted 


\section{Exhibit D7. Average Measured and Bias-Corrected (bc) Versus} Targeted Compositions by Glass \# by Oxide (continued)

(100 - Batch 1;200 - Ustd)
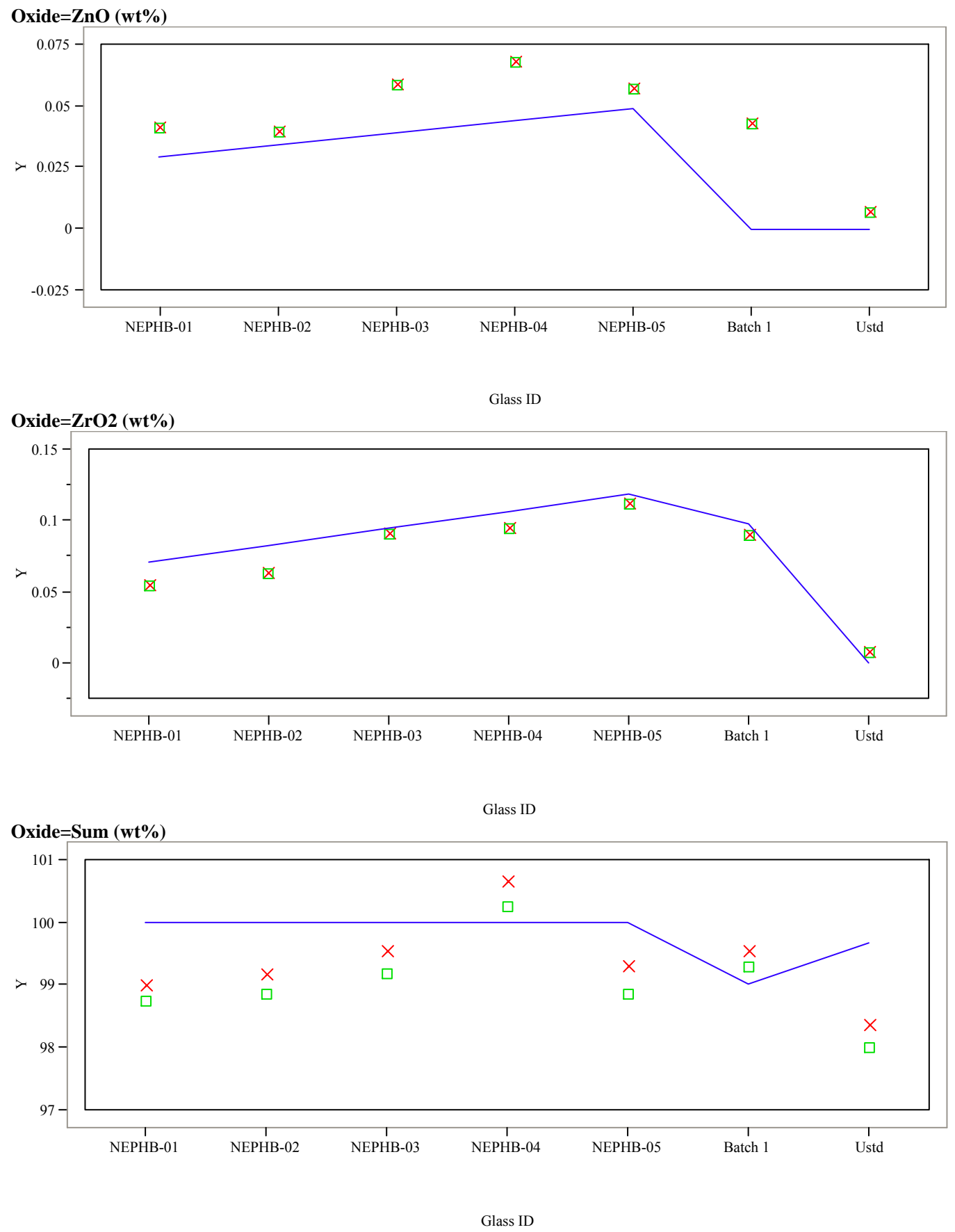

Y $\times$ Measured $\square$ Measured bc $\quad$ Targeted 
WSRC-STI-2006-00009

Revision 0

This page intentionally left blank. 


\section{Appendix E}

\section{Tables and Exhibits Supporting the Analysis of the PCT Results for the Frit 503 - SB4 Study Glasses}


Table E1. Laboratory Measurements of the PCT Solutions for the Frit 503/SB4 Study Glasses in ppm

\begin{tabular}{|c|c|c|c|c|c|c|c|c|c|c|c|c|c|c|c|}
\hline Glass ID & $\begin{array}{c}\text { Heat } \\
\text { Treatment }\end{array}$ & $\begin{array}{c}\text { Laboratory } \\
\text { ID }\end{array}$ & Block & Seq & B ar & Ba ar & Cd ar & Crar & Fe ar & $\mathrm{Li}$ ar & Na ar & Pb ar & Si ar & Th ar & $\mathrm{U}$ ar \\
\hline Soln Std & & STD-B1-1 & 1 & 1 & 19.6 & $<0.010$ & $<0.080$ & $<0.010$ & 4.56 & 9.6 & 81.4 & $<0.020$ & 49.3 & $<0.100$ & $<0.200$ \\
\hline blank & & $\mathrm{J} 02$ & 1 & 2 & 0.194 & $<0.010$ & $<0.080$ & $<0.010$ & $<0.004$ & $<0.500$ & 0.255 & $<0.020$ & $<0.100$ & $<0.100$ & $<0.200$ \\
\hline ARM-1 & & $\mathrm{J} 15$ & 1 & 3 & 10.8 & $<0.010$ & $<0.080$ & $<0.010$ & $<0.004$ & 8.35 & 22 & $<0.020$ & 36.8 & $<0.100$ & $<0.200$ \\
\hline NEPHB-04 & quenched & $\mathrm{J} 34$ & 1 & 4 & 11.2 & $<0.010$ & $<0.080$ & $<0.010$ & 2.56 & 9.47 & 39.4 & $<0.020$ & 53.3 & $<0.100$ & 1.27 \\
\hline NEPHB-04ccc & $\mathrm{ccc}$ & $\mathrm{J} 37$ & 1 & 5 & 18.4 & $<0.010$ & $<0.080$ & $<0.010$ & 3.45 & 14.2 & 48.7 & $<0.020$ & 59.7 & $<0.100$ & 1.46 \\
\hline NEPHB-05 & quenched & $\mathrm{J} 25$ & 1 & 6 & 11.8 & $<0.010$ & $<0.080$ & $<0.010$ & 3.32 & 9.08 & 50.5 & $<0.020$ & 52.2 & $<0.100$ & 1.37 \\
\hline NEPHB-03 & quenched & $\mathrm{J} 28$ & 1 & 7 & 11.4 & $<0.010$ & $<0.080$ & $<0.010$ & 2.71 & 10 & 31.3 & $<0.020$ & 57 & $<0.100$ & 1.63 \\
\hline NEPHB-01 ccc & $\mathrm{ccc}$ & $\mathrm{J} 26$ & 1 & 8 & 11.5 & $<0.010$ & $<0.080$ & $<0.010$ & 3.83 & 10.5 & 21.6 & $<0.020$ & 62.4 & $<0.100$ & 3.32 \\
\hline Soln Std & & STD-B1-2 & 1 & 9 & 19.9 & $<0.010$ & $<0.080$ & $<0.010$ & 4.59 & 9.44 & 82 & $<0.020$ & 48.2 & $<0.100$ & $<0.200$ \\
\hline EA & & $\mathrm{J} 16$ & 1 & 10 & 35.4 & $<0.010$ & $<0.080$ & $<0.010$ & $<0.004$ & 10.4 & 97.7 & $<0.020$ & 50.3 & $<0.100$ & $<0.200$ \\
\hline NEPHB-03ccc & $\mathrm{ccc}$ & $\mathrm{J} 29$ & 1 & 11 & 10.8 & $<0.010$ & $<0.080$ & $<0.010$ & 2.71 & 9.56 & 29.6 & $<0.020$ & 55.2 & $<0.100$ & 1.54 \\
\hline NEPHB-02 $\mathrm{ccc}$ & $\mathrm{ccc}$ & J04 & 1 & 12 & 10.9 & $<0.010$ & $<0.080$ & $<0.010$ & 3 & 9.78 & 23.9 & $<0.020$ & 58.9 & $<0.100$ & 1.96 \\
\hline NEPHB-01 & quenched & $\mathrm{J} 24$ & 1 & 13 & 11.6 & $<0.010$ & $<0.080$ & $<0.010$ & 4.32 & 11.3 & 19.1 & $<0.020$ & 64.6 & $<0.100$ & 3.68 \\
\hline NEPHB-02 & quenched & $\mathrm{J} 30$ & 1 & 14 & 11.1 & $<0.010$ & $<0.080$ & $<0.010$ & 3.13 & 10.4 & 23.9 & $<0.020$ & 59.6 & $<0.100$ & 2.12 \\
\hline NEPHB-05 ccc & $\mathrm{ccc}$ & $\mathrm{J} 12$ & 1 & 15 & 9.87 & $<0.010$ & $<0.080$ & $<0.010$ & 1.64 & 8.86 & 42.2 & $<0.020$ & 46.5 & $<0.100$ & 1.06 \\
\hline Soln Std & & STD-B1-3 & 1 & 16 & 19.8 & $<0.010$ & $<0.080$ & $<0.010$ & 4.47 & 9.29 & 82.6 & $<0.020$ & 47.5 & $<0.100$ & $<0.200$ \\
\hline Soln Std & & STD-B2-1 & 2 & 1 & 19.5 & $<0.010$ & $<0.080$ & $<0.010$ & 4.47 & 9.71 & 81.5 & $<0.020$ & 49.3 & $<0.100$ & $<0.200$ \\
\hline NEPHB-03 ccc & $\mathrm{ccc}$ & $\mathrm{J} 11$ & 2 & 2 & 10.8 & $<0.010$ & $<0.080$ & $<0.010$ & 2.75 & 9.63 & 30.7 & $<0.020$ & 55.1 & $<0.100$ & 1.47 \\
\hline NEPHB-01 ccc & $\mathrm{ccc}$ & $\mathrm{J} 36$ & 2 & 3 & 11.5 & $<0.010$ & $<0.080$ & $<0.010$ & 3.72 & 10.6 & 20.3 & $<0.020$ & 62.8 & $<0.100$ & 3.27 \\
\hline EA & & $\mathrm{J} 31$ & 2 & 4 & 30.6 & $<0.010$ & $<0.080$ & $<0.010$ & $<0.004$ & 9.07 & 84.2 & $<0.020$ & 44.9 & $<0.100$ & $<0.200$ \\
\hline NEPHB-05ccc & $\mathrm{ccc}$ & J06 & 2 & 5 & 11 & $<0.010$ & $<0.080$ & $<0.010$ & 2.19 & 9.34 & 46.1 & $<0.020$ & 50.5 & $<0.100$ & 1.22 \\
\hline ARM-1 & & $\mathrm{J} 14$ & 2 & 6 & 11.6 & $<0.010$ & $<0.080$ & $<0.010$ & $<0.004$ & 8.42 & 23.1 & $<0.020$ & 36.9 & $<0.100$ & $<0.200$ \\
\hline NEPHB-03 & quenched & $\mathrm{J} 35$ & 2 & 7 & 11 & $<0.010$ & $<0.080$ & $<0.010$ & 2.82 & 9.65 & 31 & $<0.020$ & 54.4 & $<0.100$ & 1.43 \\
\hline NEPHB-02 & quenched & $\mathrm{J} 32$ & 2 & 8 & 11.2 & $<0.010$ & $<0.080$ & $<0.010$ & 3.02 & 10.4 & 24.6 & $<0.020$ & 59.1 & $<0.100$ & 2.08 \\
\hline Soln Std & & STD-B2-2 & 2 & 9 & 19.9 & $<0.010$ & $<0.080$ & $<0.010$ & 4.64 & 9.48 & 83.9 & $<0.020$ & 48.4 & $<0.100$ & $<0.200$ \\
\hline NEPHB-05 & quenched & $\mathrm{J} 10$ & 2 & 10 & 11.6 & $<0.010$ & $<0.080$ & $<0.010$ & 3.22 & 9.17 & 52 & $<0.020$ & 51.1 & $<0.100$ & 1.31 \\
\hline NEPHB-04ccc & $\mathrm{ccc}$ & J08 & 2 & 11 & 18.4 & $<0.010$ & $<0.080$ & $<0.010$ & 3.08 & 14.1 & 50.7 & $<0.020$ & 59.6 & $<0.100$ & 1.47 \\
\hline NEPHB-04 & quenched & $\mathrm{J} 38$ & 2 & 12 & 11.3 & $<0.010$ & $<0.080$ & $<0.010$ & 2.61 & 9.38 & 40.7 & $<0.020$ & 52 & $<0.100$ & 1.26 \\
\hline NEPHB-02ccc & $\mathrm{ccc}$ & $\mathrm{J} 13$ & 2 & 13 & 10.9 & $<0.010$ & $<0.080$ & $<0.010$ & 2.94 & 9.79 & 25.6 & $<0.020$ & 58.3 & $<0.100$ & 1.95 \\
\hline NEPHB-01 & quenched & $\mathrm{J} 05$ & 2 & 14 & 11.4 & $<0.010$ & $<0.080$ & $<0.010$ & 4.25 & 11.1 & 19.7 & $<0.020$ & 63.8 & $<0.100$ & 3.59 \\
\hline Soln Std & & STD-B2-3 & 2 & 15 & 19.8 & $<0.010$ & $<0.080$ & $<0.010$ & 4.5 & 9.6 & 84 & $<0.020$ & 48.7 & $<0.100$ & $<0.200$ \\
\hline Soln Std & & STD-B3-1 & 3 & 1 & 19.6 & $<0.010$ & $<0.080$ & $<0.010$ & 4.5 & 9.72 & 80.4 & $<0.020$ & 51 & $<0.100$ & $<0.200$ \\
\hline
\end{tabular}


Table E1. Laboratory Measurements of the PCT Solutions for the Frit 503/SB4 Study Glasses in ppm (continued)

\begin{tabular}{|c|c|c|c|c|c|c|c|c|c|c|c|c|c|c|c|}
\hline Glass ID & $\begin{array}{c}\text { Heat } \\
\text { Treatment }\end{array}$ & $\begin{array}{c}\text { Laboratory } \\
\text { ID }\end{array}$ & Block & Seq & B ar & Ba ar & Cd ar & Cr ar & Fe ar & Li ar & Na ar & Pb ar & Si ar & Th ar & U ar \\
\hline NEPHB-01 ccc & $\mathrm{ccc}$ & $\mathrm{J} 17$ & 3 & 2 & 11.4 & $<0.010$ & $<0.080$ & $<0.010$ & 3.66 & 10.7 & 19.3 & $<0.020$ & 64.2 & $<0.100$ & 3.17 \\
\hline NEPHB-02 ccc & $\mathrm{ccc}$ & $\mathrm{J} 22$ & 3 & 3 & 10.9 & $<0.010$ & $<0.080$ & $<0.010$ & 2.94 & 10 & 24.4 & $<0.020$ & 61.2 & $<0.100$ & 1.87 \\
\hline NEPHB-05 & quenched & $\mathrm{J} 20$ & 3 & 4 & 11.2 & $<0.010$ & $<0.080$ & $<0.010$ & 3.14 & 8.98 & 49.1 & $<0.020$ & 51.9 & $<0.100$ & 1.3 \\
\hline NEPHB-02 & quenched & $\mathrm{J} 07$ & 3 & 5 & 10.9 & $<0.010$ & $<0.080$ & $<0.010$ & 3.03 & 10.4 & 23.4 & $<0.020$ & 60.3 & $<0.100$ & 1.89 \\
\hline ARM-1 & & $\mathrm{J} 19$ & 3 & 6 & 11.6 & $<0.010$ & $<0.080$ & $<0.010$ & $<0.004$ & 8.62 & 23.2 & $<0.020$ & 37.8 & $<0.100$ & $<0.200$ \\
\hline NEPHB-05 ccc & $\mathrm{ccc}$ & $\mathrm{J} 27$ & 3 & 7 & 10.7 & $<0.010$ & $<0.080$ & $<0.010$ & 2.21 & 9.65 & 47.6 & $<0.020$ & 53.5 & $<0.100$ & 1.2 \\
\hline NEPHB-03ccc & $\mathrm{ccc}$ & $\mathrm{J} 03$ & 3 & 8 & 11 & $<0.010$ & $<0.080$ & $<0.010$ & 2.75 & 9.7 & 30 & $<0.020$ & 57.9 & $<0.100$ & 1.29 \\
\hline Soln Std & & STD-B3-2 & 3 & 9 & 20.1 & $<0.010$ & $<0.080$ & $<0.010$ & 4.66 & 9.54 & 81.8 & $<0.020$ & 49.5 & $<0.100$ & $<0.200$ \\
\hline NEPHB-04 & quenched & $\mathrm{J} 33$ & 3 & 10 & 11.1 & $<0.010$ & $<0.080$ & $<0.010$ & 2.39 & 9.39 & 39.4 & $<0.020$ & 54.1 & $<0.100$ & 1.31 \\
\hline blank & & $\mathrm{J} 21$ & 3 & 11 & 0.116 & $<0.010$ & $<0.080$ & $<0.010$ & $<0.004$ & $<0.500$ & $<0.100$ & $<0.020$ & $<0.100$ & $<0.100$ & $<0.200$ \\
\hline NEPHB-04ccc & $\mathrm{ccc}$ & J09 & 3 & 12 & 18.3 & $<0.010$ & $<0.080$ & $<0.010$ & 3.18 & 14.3 & 49.3 & $<0.020$ & 62.5 & $<0.100$ & 1.47 \\
\hline EA & & $\mathrm{J} 23$ & 3 & 13 & 20.9 & $<0.010$ & $<0.080$ & $<0.010$ & $<0.004$ & 6.48 & 61.1 & $<0.020$ & 35.3 & $<0.100$ & $<0.200$ \\
\hline NEPHB-01 & quenched & $\mathrm{J} 18$ & 3 & 14 & 11.9 & $<0.010$ & $<0.080$ & $<0.010$ & 4.37 & 11.4 & 20.1 & $<0.020$ & 67.3 & $<0.100$ & 3.49 \\
\hline NEPHB-03 & quenched & $\mathrm{J} 01$ & 3 & 15 & 11.1 & $<0.010$ & $<0.080$ & $<0.010$ & 3.01 & 9.77 & 29.7 & $<0.020$ & 57.7 & $<0.100$ & 1.5 \\
\hline Soln Std & & STD-B3-3 & 3 & 16 & 20.1 & $<0.010$ & $<0.080$ & $<0.010$ & 4.62 & 9.6 & 81 & $<0.020$ & 50.7 & $<0.100$ & $<0.200$ \\
\hline
\end{tabular}


Table E2. PSAL Measurements of the PCT Solutions for the Study Glasses After Appropriate Adjustments

\begin{tabular}{|c|c|c|c|c|c|c|c|c|c|c|c|c|c|c|c|}
\hline Glass ID & $\begin{array}{c}\text { Heat } \\
\text { Treatment }\end{array}$ & Laboratory ID & Block & Seq & B (ppm) & Ba (ppm) & Cd (ppm) & Cr (ppm) & Fe (ppm) & Li (ppm) & $\mathrm{Na}$ (ppm) & Pb (ppm) & Si (ppm) & Th (ppm) & $\overline{\mathrm{U} \text { (ppm) }}$ \\
\hline Soln Std & & STD-B1-1 & 1 & 1 & 19.600 & 0.005 & 0.040 & 0.005 & 4.560 & 9.600 & 81.400 & 0.010 & 49.300 & 0.050 & 0.100 \\
\hline blank & & J02 & 1 & 2 & 0.323 & 0.008 & 0.067 & 0.008 & 0.003 & 0.417 & 0.425 & 0.017 & 0.083 & 0.083 & 0.167 \\
\hline ARM-1 & & $\mathrm{J} 15$ & 1 & 3 & 18.000 & 0.008 & 0.067 & 0.008 & 0.003 & 13.917 & 36.667 & 0.017 & 61.335 & 0.083 & 0.167 \\
\hline NEPHB-04 & quenched & $\mathrm{J} 34$ & 1 & 4 & 18.667 & 0.008 & 0.067 & 0.008 & 4.267 & 15.784 & 65.668 & 0.017 & 88.835 & 0.083 & 2.117 \\
\hline NEPHB-04ccc & $\mathrm{ccc}$ & $\mathrm{J} 37$ & 1 & 5 & 30.667 & 0.008 & 0.067 & 0.008 & 5.750 & 23.667 & 81.168 & 0.017 & 99.502 & 0.083 & 2.433 \\
\hline NEPHB-05 & quenched & $\mathrm{J} 25$ & 1 & 6 & 19.667 & 0.008 & 0.067 & 0.008 & 5.533 & 15.134 & 84.168 & 0.017 & 87.002 & 0.083 & 2.283 \\
\hline NEPHB-03 & quenched & $\mathrm{J} 28$ & 1 & 7 & 19.000 & 0.008 & 0.067 & 0.008 & 4.517 & 16.667 & 52.168 & 0.017 & 95.002 & 0.083 & 2.717 \\
\hline NEPHB-01 ccc & $\mathrm{ccc}$ & $\mathrm{J} 26$ & 1 & 8 & 19.167 & 0.008 & 0.067 & 0.008 & 6.383 & 17.500 & 36.001 & 0.017 & 104.002 & 0.083 & 5.533 \\
\hline Soln Std & & STD-B1-2 & 1 & 9 & 19.900 & 0.005 & 0.040 & 0.005 & 4.590 & 9.440 & 82.000 & 0.010 & 48.200 & 0.050 & 0.100 \\
\hline EA & & $\mathrm{J} 16$ & 1 & 10 & 590.001 & 0.083 & 0.667 & 0.083 & 0.033 & 173.334 & 1628.337 & 0.167 & 838.335 & 0.833 & 1.667 \\
\hline NEPHB-03 ccc & $\mathrm{ccc}$ & J29 & 1 & 11 & 18.000 & 0.008 & 0.067 & 0.008 & 4.517 & 15.934 & 49.334 & 0.017 & 92.002 & 0.083 & 2.567 \\
\hline NEPHB-02 ccc & $\mathrm{ccc}$ & $\mathrm{J} 04$ & 1 & 12 & 18.167 & 0.008 & 0.067 & 0.008 & 5.000 & 16.300 & 39.834 & 0.017 & 98.169 & 0.083 & 3.267 \\
\hline NEPHB-01 & quenched & $\mathrm{J} 24$ & 1 & 13 & 19.334 & 0.008 & 0.067 & 0.008 & 7.200 & 18.834 & 31.834 & 0.017 & 107.669 & 0.083 & 6.133 \\
\hline NEPHB-02 & quenched & $\mathrm{J} 30$ & 1 & 14 & 18.500 & 0.008 & 0.067 & 0.008 & 5.217 & 17.334 & 39.834 & 0.017 & 99.335 & 0.083 & 3.533 \\
\hline NEPHB-05 ccc & $\mathrm{ccc}$ & $\mathrm{J} 12$ & 1 & 15 & 16.450 & 0.008 & 0.067 & 0.008 & 2.733 & 14.767 & 70.335 & 0.017 & 77.502 & 0.083 & 1.767 \\
\hline Soln Std & & STD-B1-3 & 1 & 16 & 19.800 & 0.005 & 0.040 & 0.005 & 4.470 & 9.290 & 82.600 & 0.010 & 47.500 & 0.050 & 0.100 \\
\hline Soln Std & & STD-B2-1 & 2 & 1 & 19.500 & 0.005 & 0.040 & 0.005 & 4.470 & 9.710 & 81.500 & 0.010 & 49.300 & 0.050 & 0.100 \\
\hline NEPHB-03ccc & $\mathrm{ccc}$ & $\mathrm{J} 11$ & 2 & 2 & 18.000 & 0.008 & 0.067 & 0.008 & 4.583 & 16.050 & 51.168 & 0.017 & 91.835 & 0.083 & 2.450 \\
\hline NEPHB-01 ccc & $\mathrm{ccc}$ & $\mathrm{J} 36$ & 2 & 3 & 19.167 & 0.008 & 0.067 & 0.008 & 6.200 & 17.667 & 33.834 & 0.017 & 104.669 & 0.083 & 5.450 \\
\hline EA & & $\mathrm{J} 31$ & 2 & 4 & 510.001 & 0.083 & 0.667 & 0.083 & 0.033 & 151.167 & 1403.336 & 0.167 & 748.335 & 0.833 & 1.667 \\
\hline NEPHB-05 ccc & $\mathrm{ccc}$ & J06 & 2 & 5 & 18.334 & 0.008 & 0.067 & 0.008 & 3.650 & 15.567 & 76.835 & 0.017 & 84.168 & 0.083 & 2.033 \\
\hline ARM-1 & & $\mathrm{J} 14$ & 2 & 6 & 19.334 & 0.008 & 0.067 & 0.008 & 0.003 & 14.034 & 38.501 & 0.017 & 61.501 & 0.083 & 0.167 \\
\hline NEPHB-03 & quenched & $\mathrm{J} 35$ & 2 & 7 & 18.334 & 0.008 & 0.067 & 0.008 & 4.700 & 16.084 & 51.668 & 0.017 & 90.668 & 0.083 & 2.383 \\
\hline NEPHB-02 & quenched & $\mathrm{J} 32$ & 2 & 8 & 18.667 & 0.008 & 0.067 & 0.008 & 5.033 & 17.334 & 41.001 & 0.017 & 98.502 & 0.083 & 3.467 \\
\hline Soln Std & & STD-B2-2 & 2 & 9 & 19.900 & 0.005 & 0.040 & 0.005 & 4.640 & 9.480 & 83.900 & 0.010 & 48.400 & 0.050 & 0.100 \\
\hline NEPHB-05 & quenched & $\mathrm{J} 10$ & 2 & 10 & 19.334 & 0.008 & 0.067 & 0.008 & 5.367 & 15.284 & 86.668 & 0.017 & 85.168 & 0.083 & 2.183 \\
\hline NEPHB-04ccc & $\mathrm{ccc}$ & $\mathrm{J} 08$ & 2 & 11 & 30.667 & 0.008 & 0.067 & 0.008 & 5.133 & 23.500 & 84.502 & 0.017 & 99.335 & 0.083 & 2.450 \\
\hline NEPHB-04 & quenched & $\mathrm{J} 38$ & 2 & 12 & 18.834 & 0.008 & 0.067 & 0.008 & 4.350 & 15.634 & 67.835 & 0.017 & 86.668 & 0.083 & 2.100 \\
\hline NEPHB-02 ccc & $\mathrm{ccc}$ & $\mathrm{J} 13$ & 2 & 13 & 18.167 & 0.008 & 0.067 & 0.008 & 4.900 & 16.317 & 42.668 & 0.017 & 97.169 & 0.083 & 3.250 \\
\hline NEPHB-01 & quenched & $\mathrm{J} 05$ & 2 & 14 & 19.000 & 0.008 & 0.067 & 0.008 & 7.083 & 18.500 & 32.834 & 0.017 & 106.335 & 0.083 & 5.983 \\
\hline Soln Std & & STD-B2-3 & 2 & 15 & 19.800 & 0.005 & 0.040 & 0.005 & 4.500 & 9.600 & 84.000 & 0.010 & 48.700 & 0.050 & 0.100 \\
\hline Soln Std & & STD-B3-1 & 3 & 1 & 19.600 & 0.005 & 0.040 & 0.005 & 4.500 & 9.720 & 80.400 & 0.010 & 51.000 & 0.050 & 0.100 \\
\hline
\end{tabular}


Table E2. PSAL Measurements of the PCT Solutions for the Study Glasses After Appropriate Adjustments (continued)

\begin{tabular}{|c|c|c|c|c|c|c|c|c|c|c|c|c|c|c|c|}
\hline Glass ID & \begin{tabular}{|c|} 
Heat \\
Treatment \\
\end{tabular} & Laboratory ID & Block & Seq & B (ppm) & Ba (ppm) & Cd (ppm) & Cr (ppm) & Fe (ppm) & Li (ppm) & Na (ppm) & Pb (ppm) & Si (ppm) & Th (ppm) & $\bar{U}$ U (ppm) \\
\hline NEPHB-01 ccc & $\mathrm{ccc}$ & $\mathrm{J} 17$ & 3 & 2 & 19.000 & 0.008 & 0.067 & 0.008 & 6.100 & 17.834 & 32.167 & 0.017 & 107.002 & 0.083 & 5.283 \\
\hline NEPHB-02 ccc & $\mathrm{ccc}$ & $\mathrm{J} 22$ & 3 & 3 & 18.167 & 0.008 & 0.067 & 0.008 & 4.900 & 16.667 & 40.667 & 0.017 & 102.002 & 0.083 & 3.117 \\
\hline NEPHB-05 & quenched & $\mathrm{J} 20$ & 3 & 4 & 18.667 & 0.008 & 0.067 & 0.008 & 5.233 & 14.967 & 81.835 & 0.017 & 86.502 & 0.083 & 2.167 \\
\hline NEPHB-02 & quenched & J07 & 3 & 5 & 18.167 & 0.008 & 0.067 & 0.008 & 5.050 & 17.334 & 39.001 & 0.017 & 100.502 & 0.083 & 3.150 \\
\hline ARM-1 & & $\mathrm{J} 19$ & 3 & 6 & 19.334 & 0.008 & 0.067 & 0.008 & 0.003 & 14.367 & 38.667 & 0.017 & 63.001 & 0.083 & 0.167 \\
\hline NEPHB-05ccc & $\mathrm{ccc}$ & $\mathrm{J} 27$ & 3 & 7 & 17.834 & 0.008 & 0.067 & 0.008 & 3.683 & 16.084 & 79.335 & 0.017 & 89.168 & 0.083 & 2.000 \\
\hline NEPHB-03ccc & $\mathrm{ccc}$ & $\mathrm{J} 03$ & 3 & 8 & 18.334 & 0.008 & 0.067 & 0.008 & 4.583 & 16.167 & 50.001 & 0.017 & 96.502 & 0.083 & 2.150 \\
\hline Soln Std & & STD-B3-2 & 3 & 9 & 20.100 & 0.005 & 0.040 & 0.005 & 4.660 & 9.540 & 81.800 & 0.010 & 49.500 & 0.050 & 0.100 \\
\hline NEPHB-04 & quenched & $\mathrm{J} 33$ & 3 & 10 & 18.500 & 0.008 & 0.067 & 0.008 & 3.983 & 15.650 & 65.668 & 0.017 & 90.168 & 0.083 & 2.183 \\
\hline blank & & $\mathrm{J} 21$ & 3 & 11 & 0.193 & 0.008 & 0.067 & 0.008 & 0.003 & 0.417 & 0.083 & 0.017 & 0.083 & 0.083 & 0.167 \\
\hline NEPHB-04ccc & $\mathrm{ccc}$ & J09 & 3 & 12 & 30.501 & 0.008 & 0.067 & 0.008 & 5.300 & 23.834 & 82.168 & 0.017 & 104.169 & 0.083 & 2.450 \\
\hline EA & & $\mathrm{J} 23$ & 3 & 13 & 348.334 & 0.083 & 0.667 & 0.083 & 0.033 & 108.000 & 1018.335 & 0.167 & 588.335 & 0.833 & 1.667 \\
\hline NEPHB-01 & quenched & $\mathrm{J} 18$ & 3 & 14 & 19.834 & 0.008 & 0.067 & 0.008 & 7.283 & 19.000 & 33.501 & 0.017 & 112.169 & 0.083 & 5.817 \\
\hline NEPHB-03 & quenched & $\mathrm{J} 01$ & 3 & 15 & 18.500 & 0.008 & 0.067 & 0.008 & 5.017 & 16.284 & 49.501 & 0.017 & 96.169 & 0.083 & 2.500 \\
\hline Soln Std & & STD-B3-3 & 3 & 16 & 20.100 & 0.005 & 0.040 & 0.005 & 4.620 & 9.600 & 81.000 & 0.010 & 50.700 & 0.050 & 0.100 \\
\hline
\end{tabular}


Table E3. Laboratory Measurements As-Received of the PCT Solutions for the Re-Tested ccc Glasses

\begin{tabular}{|c|c|c|c|c|c|c|c|c|c|c|c|c|c|c|c|}
\hline Glass ID & $\begin{array}{c}\text { Heat } \\
\text { Treatment }\end{array}$ & $\begin{array}{c}\text { Laboratory } \\
\text { ID }\end{array}$ & Block & Seq & B ar & Ba ar & Cd ar & Crar & Fe ar & Li ar & Na ar & Pb ar & Si ar & Th ar & U ar \\
\hline Soln Std & & $\begin{array}{l}\text { STD-B1-1 } \\
\end{array}$ & 4 & 1 & 21.2 & $<0.010$ & $<0.080$ & $<0.010$ & 4.04 & 10.0 & 79.6 & $<0.020$ & 52.6 & $<0.100$ & $<0.200$ \\
\hline EA & & K05 & 4 & 2 & 22.8 & $<0.010$ & $<0.080$ & $<0.010$ & $<0.040$ & 8.01 & 62.1 & $<0.020$ & 38.1 & $<0.100$ & $<0.200$ \\
\hline NEPHB-01ccc & $\mathrm{ccc}$ & K17 & 4 & 3 & 11.9 & $<0.010$ & $<0.080$ & $<0.010$ & 4.04 & 11.1 & 19.2 & $<0.020$ & 62.5 & $<0.100$ & 3.35 \\
\hline NEPHB-02ccc & $\mathrm{ccc}$ & K22 & 4 & 4 & 11.5 & $<0.010$ & $<0.080$ & $<0.010$ & 3.72 & 10.4 & 23.2 & $<0.020$ & 58.5 & $<0.100$ & 1.95 \\
\hline ARM-1 & & K18 & 4 & 5 & 11.3 & $<0.010$ & $<0.080$ & $<0.010$ & $<0.040$ & 9.51 & 23.7 & $<0.020$ & 39.5 & $<0.100$ & $<0.200$ \\
\hline Soln Std & & STD-B1-2 & 4 & 6 & 20.9 & $<0.010$ & $<0.080$ & $<0.010$ & 4.15 & 10.7 & 78.6 & $<0.020$ & 53.4 & $<0.100$ & $<0.200$ \\
\hline blank & & K08 & 4 & 7 & $<0.100$ & $<0.010$ & $<0.080$ & $<0.010$ & $<0.040$ & $<0.500$ & $<0.100$ & $<0.020$ & $<0.100$ & $<0.100$ & $<0.200$ \\
\hline NEPHB-04ccc & $\mathrm{ccc}$ & K21 & 4 & 8 & 22.2 & $<0.010$ & $<0.080$ & $<0.010$ & 3.94 & 18.6 & 50.7 & $<0.020$ & 61.8 & $<0.100$ & 1.50 \\
\hline NEPHB-03ccc & $\mathrm{ccc}$ & K23 & 4 & 9 & 11.2 & $<0.010$ & $<0.080$ & $<0.010$ & 3.00 & 9.92 & 28.1 & $<0.020$ & 54.4 & $<0.100$ & 1.52 \\
\hline NEPHB-05ccc & $\mathrm{ccc}$ & K13 & 4 & 10 & 10.8 & $<0.010$ & $<0.080$ & $<0.010$ & 1.89 & 9.81 & 42.6 & $<0.020$ & 49.7 & $<0.100$ & 1.12 \\
\hline Soln Std & & STD-B1-3 & 4 & 11 & 20.9 & $<0.010$ & $<0.080$ & $<0.010$ & 4.38 & 10.4 & 78.1 & $<0.020$ & 51.9 & $<0.100$ & $<0.200$ \\
\hline Soln Std & & STD-B2-1 & 5 & 1 & 21.9 & $<0.010$ & $<0.080$ & $<0.010$ & 4.47 & 9.86 & 77.4 & $<0.020$ & 52.2 & $<0.100$ & $<0.200$ \\
\hline NEPHB-03ccc & $\mathrm{ccc}$ & K16 & 5 & 2 & 11.9 & $<0.010$ & $<0.080$ & $<0.010$ & 3.36 & 9.88 & 29.9 & $<0.020$ & 53.6 & $<0.100$ & 1.44 \\
\hline ARM-1 & & K02 & 5 & 3 & 13.5 & $<0.010$ & $<0.080$ & $<0.010$ & $<0.040$ & 9.48 & 23.8 & $<0.020$ & 38.5 & $<0.100$ & $<0.200$ \\
\hline NEPHB-01ccc & $\mathrm{ccc}$ & K01 & 5 & 4 & 11.8 & $<0.010$ & $<0.080$ & $<0.010$ & 4.10 & 10.7 & 18.7 & $<0.020$ & 59.2 & $<0.100$ & 3.09 \\
\hline NEPHB-02ccc & $\mathrm{ccc}$ & K06 & 5 & 5 & 11.3 & $<0.010$ & $<0.080$ & $<0.010$ & 3.63 & 10.2 & 23.7 & $<0.020$ & 56.1 & $<0.100$ & 1.80 \\
\hline Soln Std & & STD-B2-2 & 5 & 6 & 20.9 & $<0.010$ & $<0.080$ & $<0.010$ & 4.49 & 9.73 & 80.5 & $<0.020$ & 51.4 & $<0.100$ & $<0.200$ \\
\hline NEPHB-04ccc & $\mathrm{ccc}$ & K09 & 5 & 7 & 22.4 & $<0.010$ & $<0.080$ & $<0.010$ & 4.07 & 17.7 & 51.8 & $<0.020$ & 58.5 & $<0.100$ & 1.46 \\
\hline EA & & K15 & 5 & 8 & 22.8 & $<0.010$ & $<0.080$ & $<0.010$ & $<0.040$ & 7.73 & 62.4 & $<0.020$ & 36.6 & $<0.100$ & $<0.200$ \\
\hline NEPHB-05ccc & $\mathrm{ccc}$ & K12 & 5 & 9 & 10.7 & $<0.010$ & $<0.080$ & $<0.010$ & 2.18 & 9.40 & 45.6 & $<0.020$ & 46.7 & $<0.100$ & 1.08 \\
\hline Soln Std & & STD-B2-3 & 5 & 10 & 20.7 & $<0.010$ & $<0.080$ & $<0.010$ & 4.30 & 9.55 & 82.2 & $<0.020$ & 49.8 & $<0.100$ & $<0.200$ \\
\hline Soln Std & & STD-B3-1 & 6 & 1 & 21.4 & $<0.010$ & $<0.080$ & $<0.010$ & 4.18 & 9.79 & 83.0 & $<0.020$ & 52.4 & $<0.100$ & $<0.200$ \\
\hline NEPHB-04ccc & $\mathrm{ccc}$ & K03 & 6 & 2 & 23.8 & $<0.010$ & $<0.080$ & $<0.010$ & 6.32 & 18.2 & 53.9 & $<0.020$ & 60.8 & $<0.100$ & 1.64 \\
\hline NEPHB-02ccc & $\mathrm{ccc}$ & K10 & 6 & 3 & 11.7 & $<0.010$ & $<0.080$ & $<0.010$ & 3.43 & 10.3 & 23.2 & $<0.020$ & 56.8 & $<0.100$ & 1.81 \\
\hline EA & & K20 & 6 & 4 & 36.2 & $<0.010$ & $<0.080$ & $<0.010$ & $<0.040$ & 11.3 & 94.9 & $<0.020$ & 48.6 & $<0.100$ & $<0.200$ \\
\hline NEPHB-03ccc & $\mathrm{ccc}$ & $\mathrm{K} 11$ & 6 & 5 & 11.1 & $<0.010$ & $<0.080$ & $<0.010$ & 3.07 & 9.94 & 29.9 & $<0.020$ & 53.8 & $<0.100$ & 1.37 \\
\hline Soln Std & & STD-B-3-2 & 6 & 6 & 21.2 & $<0.010$ & $<0.080$ & $<0.010$ & 4.49 & 9.87 & 81.4 & $<0.020$ & 53.0 & $<0.100$ & $<0.200$ \\
\hline ARM-1 & & K04 & 6 & 7 & 14.0 & $<0.010$ & $<0.080$ & $<0.010$ & $<0.040$ & 10.0 & 27.1 & $<0.020$ & 40.3 & $<0.100$ & $<0.200$ \\
\hline blank & & K19 & 6 & 8 & $<0.100$ & $<0.010$ & $<0.080$ & $<0.010$ & $<0.040$ & $<0.500$ & $<0.100$ & $<0.020$ & $<0.100$ & $<0.100$ & $<0.200$ \\
\hline NEPHB-05 ccc & $\mathrm{ccc}$ & K07 & 6 & 9 & 10.2 & $<0.010$ & $<0.080$ & $<0.010$ & 2.32 & 9.56 & 44.8 & $<0.020$ & 48.6 & $<0.100$ & 1.15 \\
\hline NEPHB-01 ccc & $\mathrm{ccc}$ & K14 & 6 & 10 & 11.3 & $<0.010$ & $<0.080$ & $<0.010$ & 4.41 & 11.4 & 19.8 & $<0.020$ & 62.8 & $<0.100$ & 3.18 \\
\hline Soln Std & & STD-B3-3 & 6 & 11 & 21.0 & $<0.010$ & $<0.080$ & $<0.010$ & 4.47 & 9.85 & 82.2 & $<0.020$ & 52.5 & $<0.100$ & $<0.200$ \\
\hline
\end{tabular}


Table E4. Laboratory Measurements after Adjustments of the PCT Solutions for the Re-Tested ccc Glasses

\begin{tabular}{|c|c|c|c|c|c|c|c|c|c|c|c|c|c|c|c|}
\hline Glass ID & $\begin{array}{c}\text { Heat } \\
\text { Treatment }\end{array}$ & $\begin{array}{c}\begin{array}{c}\text { Laboratory } \\
\text { ID }\end{array} \\
\end{array}$ & Block & Seq & $\begin{array}{c}\text { B } \\
(\mathbf{p p m})\end{array}$ & $\begin{array}{c}\text { Ba } \\
\text { (ppm) }\end{array}$ & $\begin{array}{c}\text { Cd } \\
\text { (ppm) }\end{array}$ & $\begin{array}{c}\mathbf{C r} \\
(\mathbf{p p m})\end{array}$ & $\begin{array}{c}\mathbf{F e} \\
(\mathbf{p p m})\end{array}$ & Li (ppm) & $\begin{array}{c}\text { Na } \\
(\mathbf{p p m})\end{array}$ & $\begin{array}{c}\mathbf{P b} \\
(\mathbf{p p m})\end{array}$ & $\begin{array}{c}\mathbf{S i} \\
(\mathbf{p p m})\end{array}$ & $\begin{array}{c}\text { Th } \\
\text { (ppm) }\end{array}$ & $\begin{array}{c}\mathrm{U} \\
(\mathbf{p p m})\end{array}$ \\
\hline Soln Std & & STD-B1-1 & 4 & 1 & 21.200 & 0.005 & 0.040 & 0.005 & 4.040 & 10.000 & 79.600 & 0.010 & 52.600 & 0.050 & 0.100 \\
\hline EA & & K05 & 4 & 2 & 380.001 & 0.083 & 0.667 & 0.083 & 0.333 & 133.500 & 1035.002 & 0.167 & 635.001 & 0.833 & 1.667 \\
\hline NEPHB-01ccc & $\mathrm{ccc}$ & $\mathrm{K} 17$ & 4 & 3 & 19.834 & 0.008 & 0.067 & 0.008 & 6.733 & 18.500 & 32.001 & 0.017 & 104.169 & 0.083 & 5.583 \\
\hline NEPHB-02ccc & $\mathrm{ccc}$ & $\mathrm{K} 22$ & 4 & 4 & 19.167 & 0.008 & 0.067 & 0.008 & 6.200 & 17.334 & 38.667 & 0.017 & 97.502 & 0.083 & 3.250 \\
\hline ARM-1 & & K18 & 4 & 5 & 18.834 & 0.008 & 0.067 & 0.008 & 0.033 & 15.850 & 39.501 & 0.017 & 65.835 & 0.083 & 0.167 \\
\hline Soln Std & & STD-B1-2 & 4 & 6 & 20.900 & 0.005 & 0.040 & 0.005 & 4.150 & 10.700 & 78.600 & 0.010 & 53.400 & 0.050 & 0.100 \\
\hline blank & & K08 & 4 & 7 & 0.083 & 0.008 & 0.067 & 0.008 & 0.033 & 0.417 & 0.083 & 0.017 & 0.083 & 0.083 & 0.167 \\
\hline NEPHB-04ccc & $\mathrm{ccc}$ & K21 & 4 & 8 & 37.001 & 0.008 & 0.067 & 0.008 & 6.567 & 31.001 & 84.502 & 0.017 & 103.002 & 0.083 & 2.500 \\
\hline NEPHB-03ccc & $\mathrm{ccc}$ & $\mathrm{K} 23$ & 4 & 9 & 18.667 & 0.008 & 0.067 & 0.008 & 5.000 & 16.534 & 46.834 & 0.017 & 90.668 & 0.083 & 2.533 \\
\hline NEPHB-05ccc & $\mathrm{ccc}$ & K13 & 4 & 10 & 18.000 & 0.008 & 0.067 & 0.008 & 3.150 & 16.350 & 71.001 & 0.017 & 82.835 & 0.083 & 1.867 \\
\hline Soln Std & & STD-B1-3 & 4 & 11 & 20.900 & 0.005 & 0.040 & 0.005 & 4.380 & 10.400 & 78.100 & 0.010 & 51.900 & 0.050 & 0.100 \\
\hline Soln Std & & STD-B2-1 & 5 & 1 & 21.900 & 0.005 & 0.040 & 0.005 & 4.470 & 9.860 & 77.400 & 0.010 & 52.200 & 0.050 & 0.100 \\
\hline NEPHB-03ccc & $\mathrm{ccc}$ & K16 & 5 & 2 & 19.834 & 0.008 & 0.067 & 0.008 & 5.600 & 16.467 & 49.834 & 0.017 & 89.335 & 0.083 & 2.400 \\
\hline ARM-1 & & K02 & 5 & 3 & 22.500 & 0.008 & 0.067 & 0.008 & 0.033 & 15.800 & 39.667 & 0.017 & 64.168 & 0.083 & 0.167 \\
\hline NEPHB-01ccc & $\mathrm{ccc}$ & K01 & 5 & 4 & 19.667 & 0.008 & 0.067 & 0.008 & 6.833 & 17.834 & 31.167 & 0.017 & 98.669 & 0.083 & 5.150 \\
\hline NEPHB-02ccc & $\mathrm{ccc}$ & K06 & 5 & 5 & 18.834 & 0.008 & 0.067 & 0.008 & 6.050 & 17.000 & 39.501 & 0.017 & 93.502 & 0.083 & 3.000 \\
\hline Soln Std & & STD-B2-2 & 5 & 6 & 20.900 & 0.005 & 0.040 & 0.005 & 4.490 & 9.730 & 80.500 & 0.010 & 51.400 & 0.050 & 0.100 \\
\hline NEPHB-04ccc & $\mathrm{ccc}$ & K09 & 5 & 7 & 37.334 & 0.008 & 0.067 & 0.008 & 6.783 & 29.501 & 86.335 & 0.017 & 97.502 & 0.083 & 2.433 \\
\hline EA & & K15 & 5 & 8 & 380.001 & 0.083 & 0.667 & 0.083 & 0.333 & 128.834 & 1040.002 & 0.167 & 610.001 & 0.833 & 1.667 \\
\hline NEPHB-05ccc & $\mathrm{ccc}$ & K12 & 5 & 9 & 17.834 & 0.008 & 0.067 & 0.008 & 3.633 & 15.667 & 76.002 & 0.017 & 77.835 & 0.083 & 1.800 \\
\hline Soln Std & & STD-B2-3 & 5 & 10 & 20.700 & 0.005 & 0.040 & 0.005 & 4.300 & 9.550 & 82.200 & 0.010 & 49.800 & 0.050 & 0.100 \\
\hline Soln Std & & STD-B3-1 & 6 & 1 & 21.400 & 0.005 & 0.040 & 0.005 & 4.180 & 9.790 & 83.000 & 0.010 & 52.400 & 0.050 & 0.100 \\
\hline NEPHB-04ccc & $\mathrm{ccc}$ & K03 & 6 & 2 & 39.667 & 0.008 & 0.067 & 0.008 & 10.534 & 30.334 & 89.835 & 0.017 & 101.335 & 0.083 & 2.733 \\
\hline NEPHB-02ccc & $\mathrm{ccc}$ & $\mathrm{K} 10$ & 6 & 3 & 19.500 & 0.008 & 0.067 & 0.008 & 5.717 & 17.167 & 38.667 & 0.017 & 94.669 & 0.083 & 3.017 \\
\hline EA & & K20 & 6 & 4 & 603.335 & 0.083 & 0.667 & 0.083 & 0.333 & 188.334 & 1581.670 & 0.167 & 810.002 & 0.833 & 1.667 \\
\hline NEPHB-03ccc & $\mathrm{ccc}$ & K11 & 6 & 5 & 18.500 & 0.008 & 0.067 & 0.008 & 5.117 & 16.567 & 49.834 & 0.017 & 89.668 & 0.083 & 2.283 \\
\hline Soln Std & & STD-B-3-2 & 6 & 6 & 21.200 & 0.005 & 0.040 & 0.005 & 4.490 & 9.870 & 81.400 & 0.010 & 53.000 & 0.050 & 0.100 \\
\hline ARM-1 & & K04 & 6 & 7 & 23.334 & 0.008 & 0.067 & 0.008 & 0.033 & 16.667 & 45.168 & 0.017 & 67.168 & 0.083 & 0.167 \\
\hline blank & & K19 & 6 & 8 & 0.083 & 0.008 & 0.067 & 0.008 & 0.033 & 0.417 & 0.083 & 0.017 & 0.083 & 0.083 & 0.167 \\
\hline NEPHB-05ccc & $\mathrm{ccc}$ & K07 & 6 & 9 & 17.000 & 0.008 & 0.067 & 0.008 & 3.867 & 15.934 & 74.668 & 0.017 & 81.002 & 0.083 & 1.917 \\
\hline NEPHB-01ccc & $\mathrm{ccc}$ & K14 & 6 & 10 & 18.834 & 0.008 & 0.067 & 0.008 & 7.350 & 19.000 & 33.001 & 0.017 & 104.669 & 0.083 & 5.300 \\
\hline Soln Std & & STD-B3-3 & 6 & 11 & 21.000 & 0.005 & 0.040 & 0.005 & 4.470 & 9.850 & 82.200 & 0.010 & 52.500 & 0.050 & 0.100 \\
\hline
\end{tabular}


Exhibit E1. Laboratory PCT Measurements in Analytical Sequence for Study Glasses, EA, ARM, Blanks, and Solution Standards
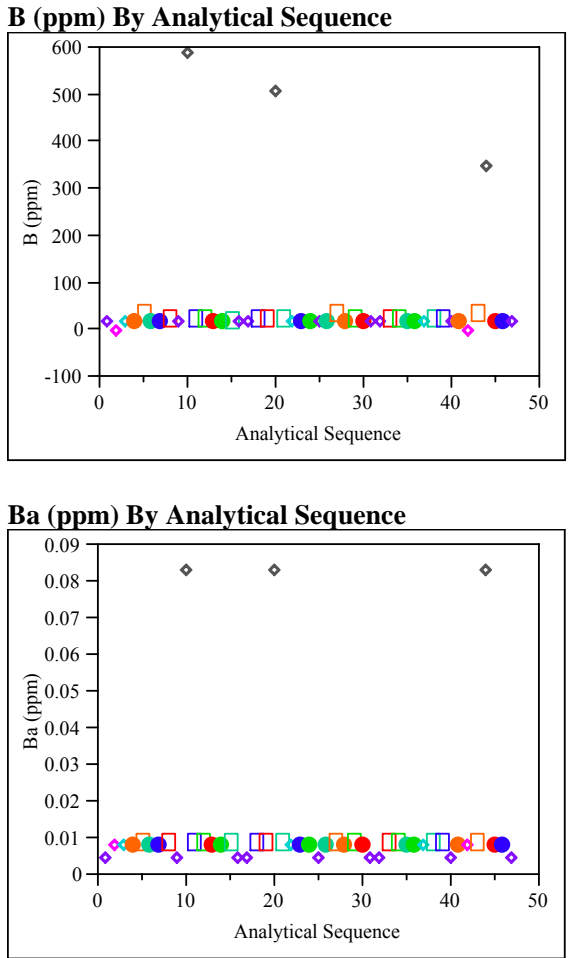

Cd (ppm) By Analytical Sequence
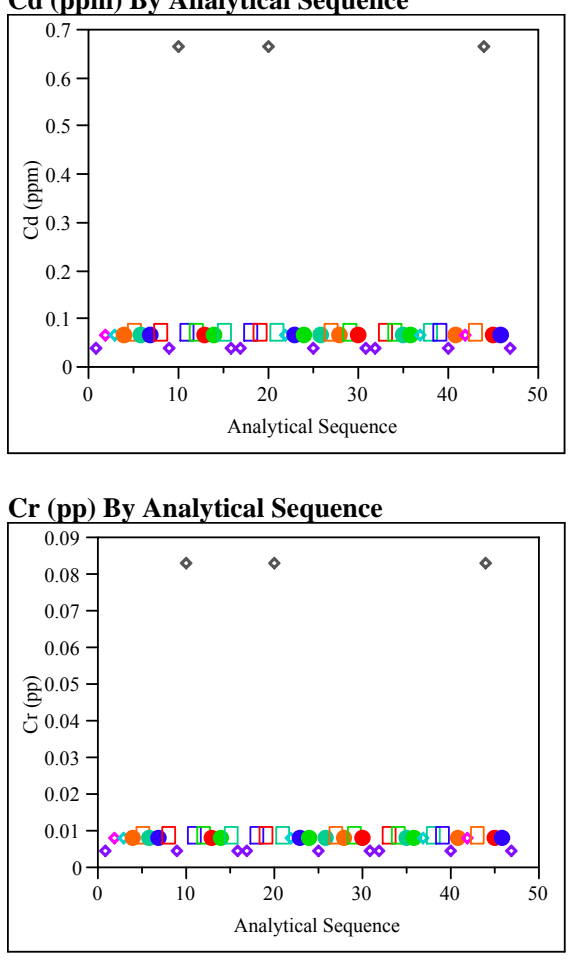

Fe (ppm) By Analytical Sequence
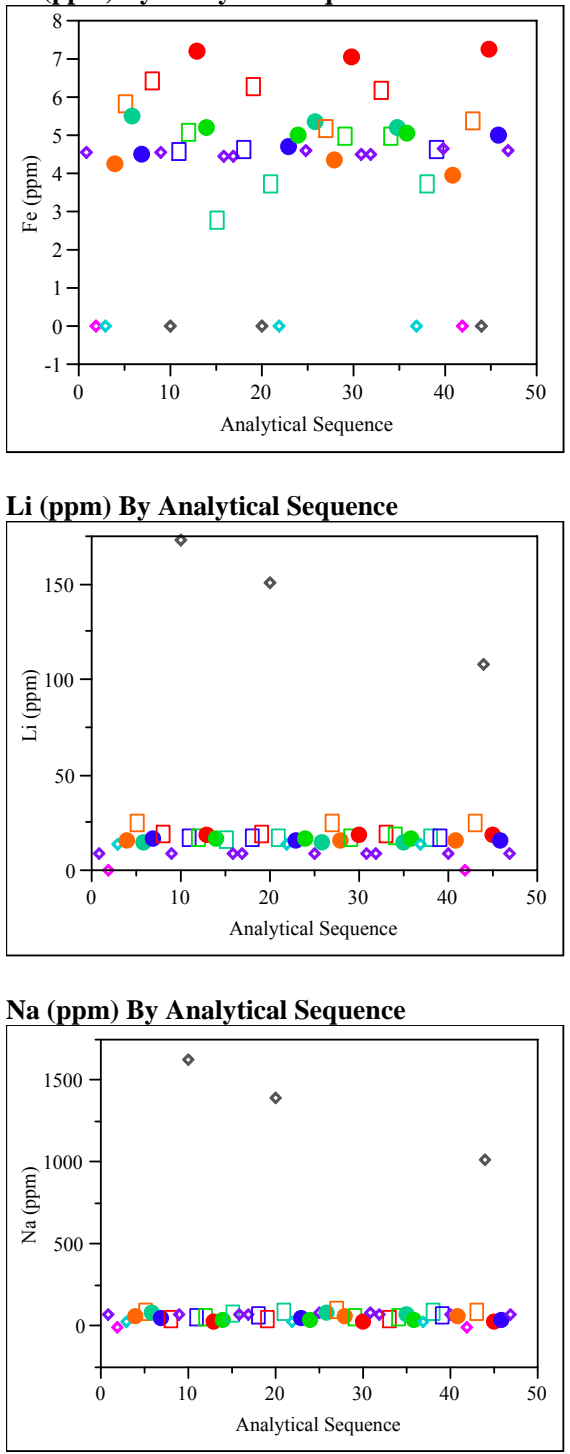

Pb (ppm) By Analytical Sequence

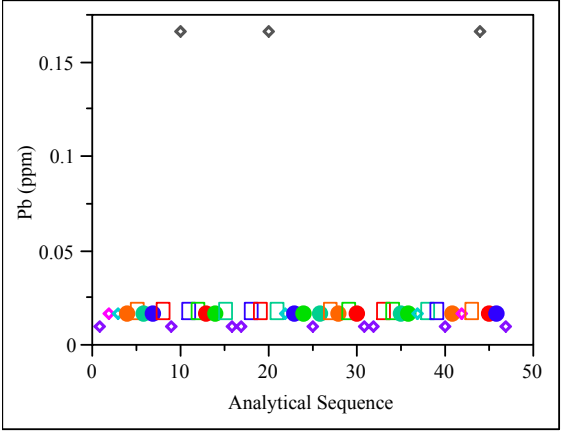

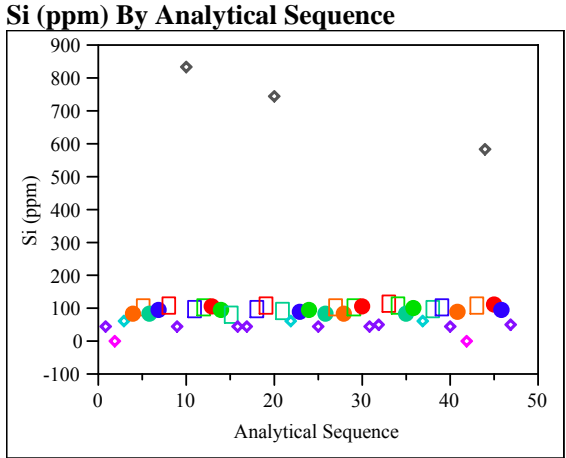

Th (ppm) By Analytical Sequence
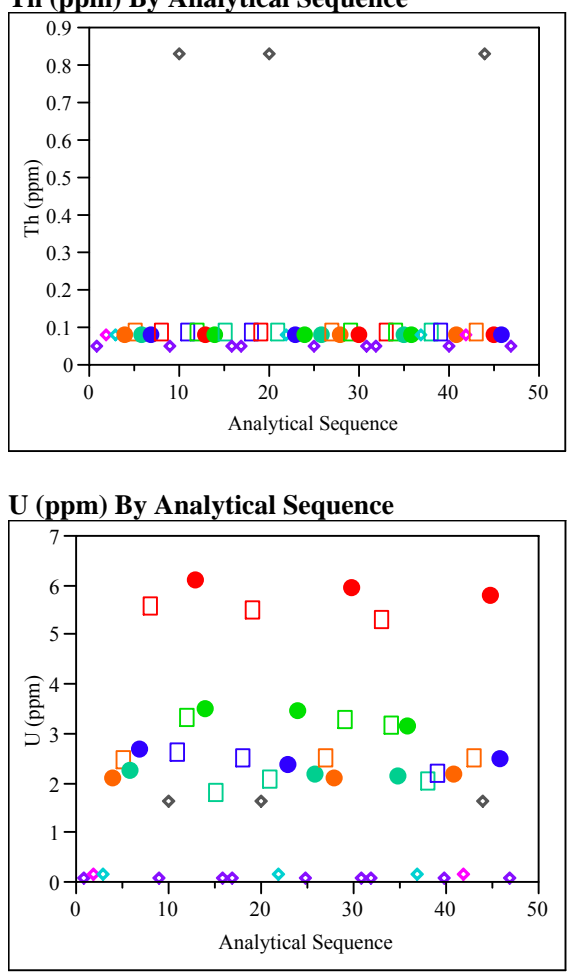


\section{Exhibit E2. Laboratory PCT Measurements in Analytical Sequence for Study Glasses}
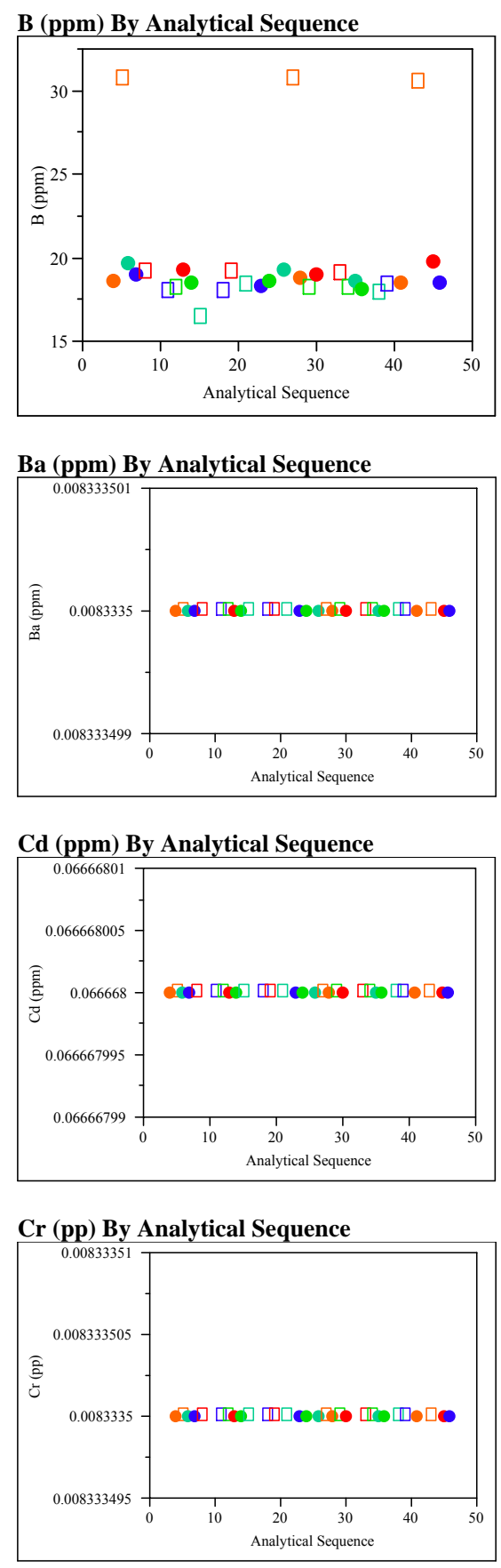

Fe (ppm) By Analytical Sequence

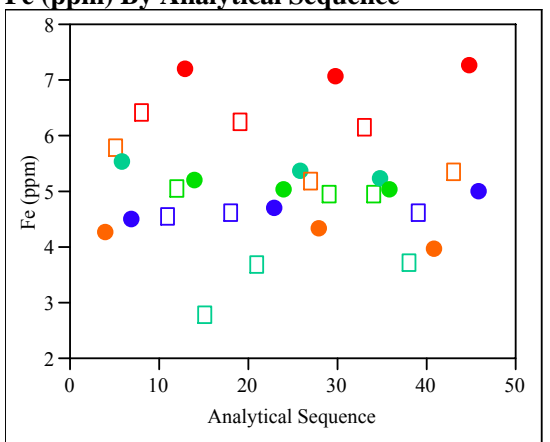

Li (ppm) By Analytical Sequence

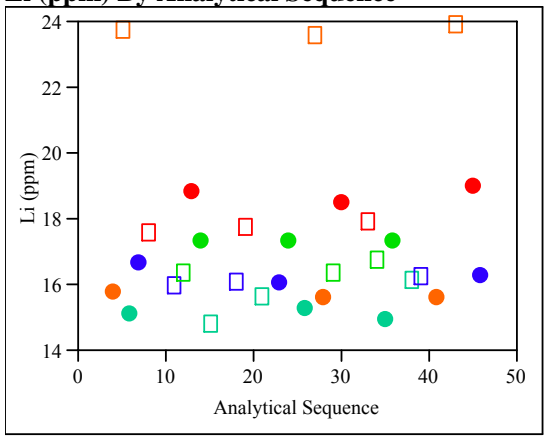

Na (ppm) By Analytical Sequence

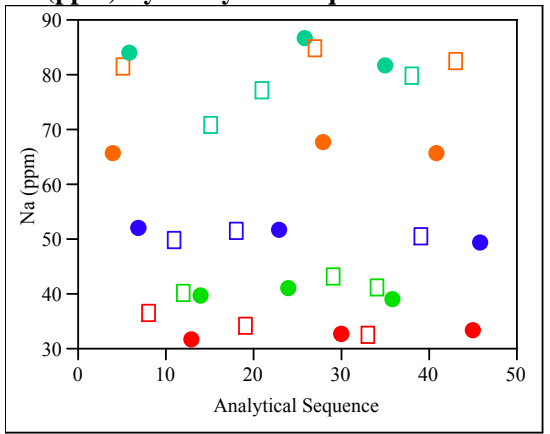

Pb (ppm) By Analytical Sequence

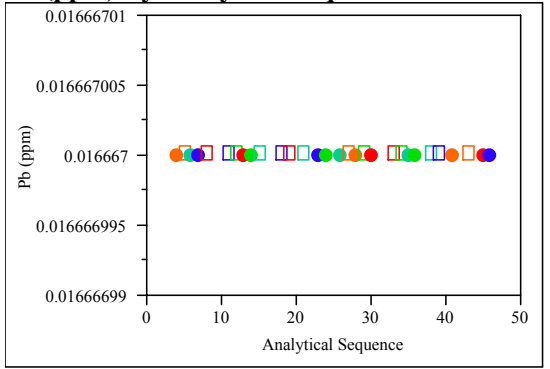

Si (ppm) By Analytical Sequence

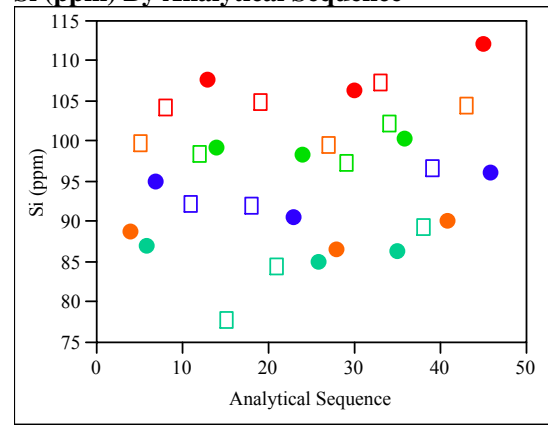

Th (ppm) By Analytical Sequence

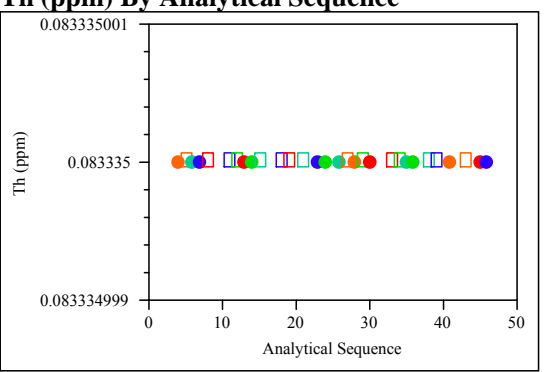

U (ppm) By Analytical Sequence

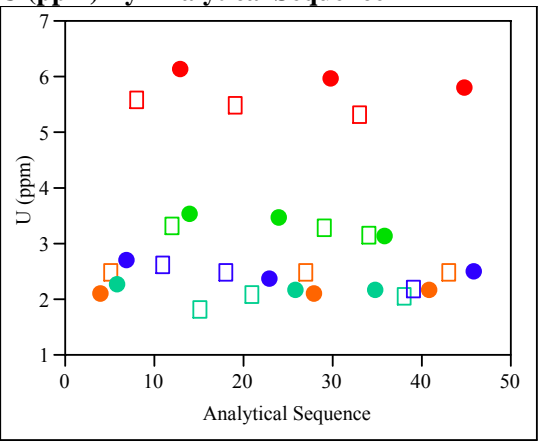




\section{Exhibit E3. Measurements of the Multi-Element Solution Standard by ICP-AES Block}

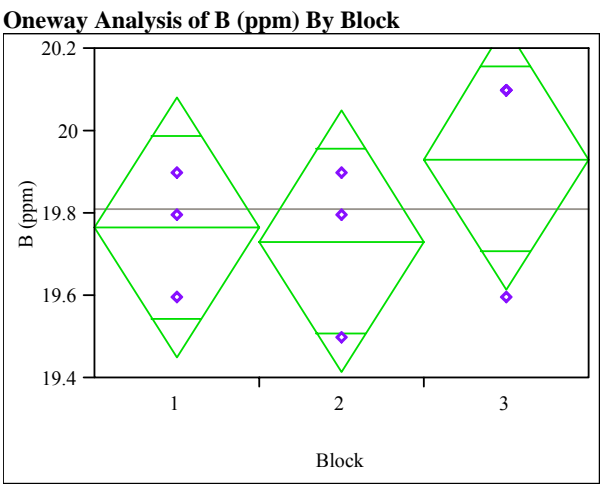

\section{Oneway Anova}

Summary of Fit

$\begin{array}{lr}\text { Rsquare } & 0.186747 \\ \text { Adj Rsquare } & -0.08434 \\ \text { Root Mean Square Error } & 0.223607 \\ \text { Mean of Response } & 19.81111 \\ \text { Observations (or Sum Wgts) } & 9\end{array}$

Analysis of Variance

Source DF Sum of Squares Mean Square F Ratio Prob $>$ F $\begin{array}{lllllll}\text { Block } & 2 & 0.06888889 & 0.034444 & 0.6889 & 0.5379\end{array}$ $\begin{array}{lll}\text { Error } & 6 & 0.30000000 \\ \text { C. Total } & 8 & 0.36888889\end{array}$

Means for Oneway Anova

Level Number Mean Std Error Lower 95\% Upper 95\% $\begin{array}{llllll}1 & 3 & 19.7667 & 0.12910 & 19.451 & 20.083 \\ 2 & 3 & 19.7333 & 0.12910 & 19.417 & 20.049\end{array}$ $\begin{array}{llllll}2 & 3 & 19.7333 & 0.12910 & 19.417 & 20.049 \\ 3 & 3 & 19.9333 & 0.12910 & 19.617 & 20.249\end{array}$ Std Error uses a pooled estimate of error variance

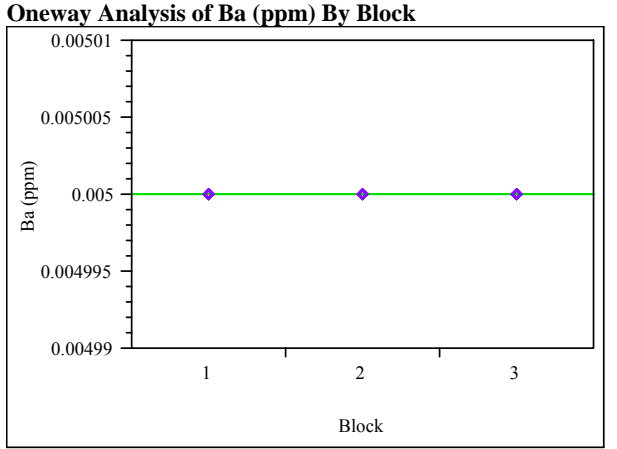

\section{Oneway Anova}

Rsquare

Adj Rsquare

$\begin{array}{lr}\text { Root Mean Square Error } & 0 \\ \text { Mean of Response } & 0.005\end{array}$

Mean of Response

Analysis of Variance

Source DF Sum of Squares Mean Square F Ratio Prob $>$ F $\begin{array}{llll}\text { Block } & 2 & 0 & 0 \\ \text { Error } & 6 & 0 & 0\end{array}$

C. Total $8 \quad 0$

Means for Oneway Anova

Level Number Mean Std Error Lower 95\% Upper 95\%

$\begin{array}{llllll}1 & 3 & 0.005000 & 0 & 0.00500 & 0.00500\end{array}$

$\begin{array}{llllll}1 & 3 & 0.005000 & 0 & 0.00500 & 0.00500 \\ 2 & 3 & 0.005000 & 0 & 0.00500 & 0.00500 \\ 3 & 3 & 0.005000 & 0 & 0.00500 & 0.00500\end{array}$

Std Error uses a pooled estimate of error variance

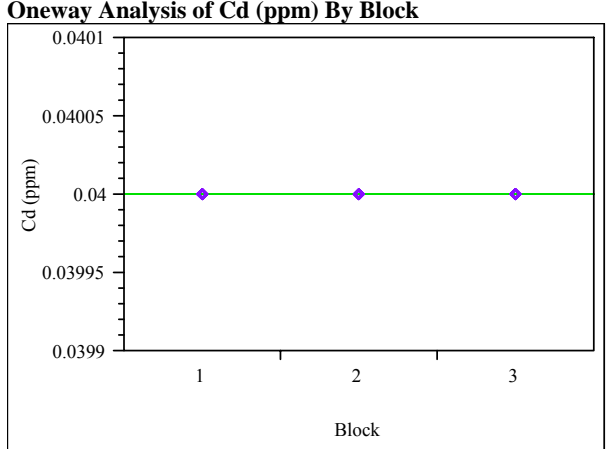

Oneway Anova

Summary of Fit

Rsquare

Adj Rsquare

Root Mean Square Error

Mean of Response 0.04

Analysis of Variance

Analysis of Variance
Source DF Sum of Squares Mean Square F Ratio Prob $>$ F

Block 220

$\begin{array}{ll}\text { Block } & 2 \\ \text { Error } & 6\end{array}$

\begin{tabular}{ll} 
C. Total 8 \\
\hline
\end{tabular}

Means for Oneway Anova

Level Number Mean Std Error Lower 95\% Upper 95\%

Lever Std Error Lower 95\% Upper 95\%

$\begin{array}{llllll}1 & 3 & 0.040000 & 0 & 0.04000 & 0.04000 \\ 2 & 3 & 0.040000 & 0 & 0.04000 & 0.04000 \\ 3 & 3 & 0.040000 & 0 & 0.04000 & 0.04000\end{array}$

Std Error uses a pooled estimate of error variance 


\section{Exhibit E3. Measurements of the Multi-Element Solution Standard by ICP-AES Block (continued)}

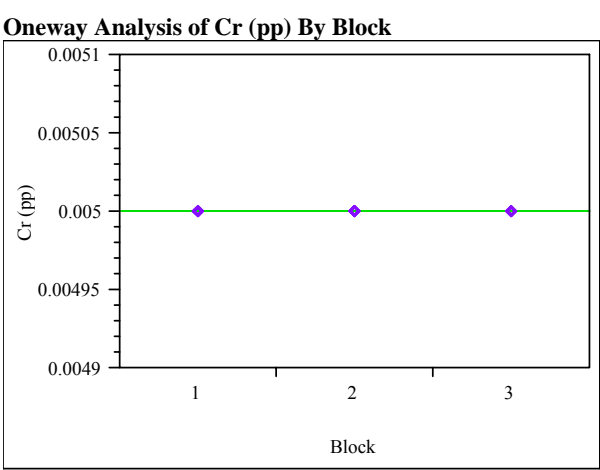

Oneway Anova

Summary of Fit

\section{Rsquare}

Adj Rsquare

Root Mean Square Error

Mean of Response

(20)

$\begin{array}{lr}\text { Mean of Response } & 0.005 \\ \text { Observations (or Sum Wgts) } & 9 \\ \text { Analysis of Variance } & \end{array}$

$\begin{array}{crrrr}\text { Source } & \text { DF } & \text { Sum of Squares } & \text { Mean Square } & \text { F Ratio Prob }>\text { F } \\ \text { Block } & 2 & 0 & 0 \\ \text { Error } & 6 & 0 & 0\end{array}$

$\begin{array}{ll}\text { Error } & 6 \\ \text { C. Total } & 8\end{array}$

Means for Oneway Anova

Means for Oneway Anova
Level Number Mean Std Error Lower 95\% Upper 95\%

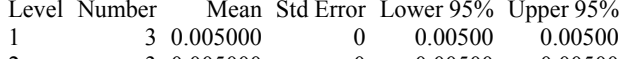

$\begin{array}{llrlrr}1 & 3 & 0.005000 & 0 & 0.00500 & 0.00500 \\ 2 & 3 & 0.005000 & 0 & 0.00500 & 0.00500 \\ 3 & 3 & 0.005000 & 0 & 0.00500 & 0.00500\end{array}$

Std Error uses a pooled estimate of error variance

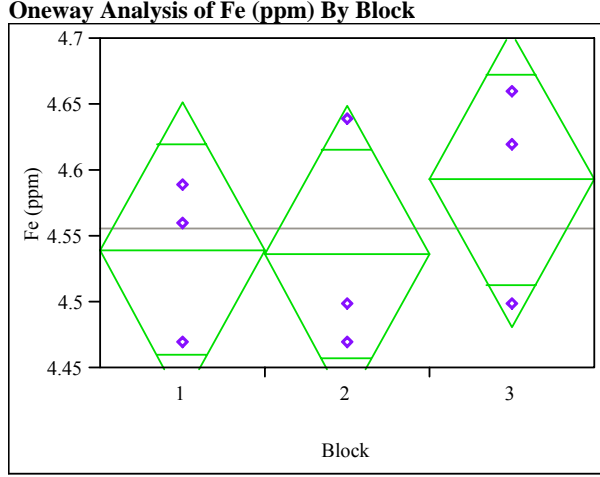

\section{Oneway Anova}

\section{Rsquare}

Root Mean Square Error $\quad 0.079722$

Mean of Response 4.556667

Analysis of Variance

Source DF Sum of Squares Mean Square F Ratio Prob > F

$\begin{array}{lrrrrr}\text { Block } & 2 & 0.00606667 & 0.003033 & 0.4773 & 0.6422\end{array}$

$\begin{array}{llll}\text { Error } & 6 & 0.03813333 & 0.006356\end{array}$

$\begin{array}{lll}\text { C. Total } & 8 & 0.04420000\end{array}$

Means for Oneway Anova

Level Number Mean Std Error Lower 95\% Upper 95\%

$\begin{array}{lllrrr}1 & 3 & 4.54000 & 0.04603 & 4.4274 & 4.6526 \\ 2 & 3 & 4.53667 & 0.04603 & 4.4240 & 4.6493\end{array}$

$\begin{array}{llllll}2 & 3 & 4.53667 & 0.04603 & 4.4240 & 4.6493 \\ 3 & 3 & 4.59333 & 0.04603 & 4.4807 & 4.7060\end{array}$

Std Error uses a pooled estimate of error variance

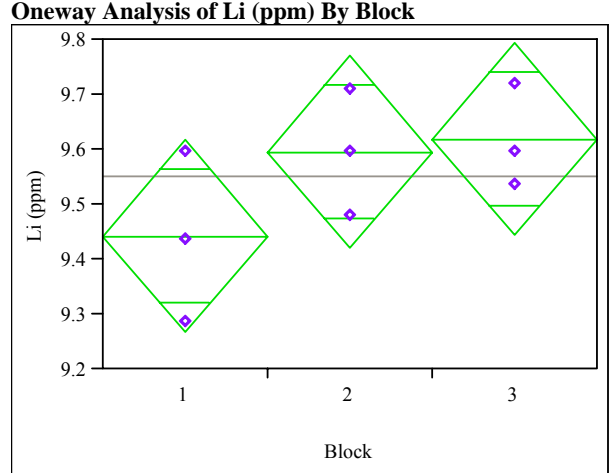

Oneway Anova

Summary of Fit

$\begin{array}{lr}\text { Rsquare } & 0.37699 \\ \text { Adj Rsquare } & 0.169319\end{array}$

Root Mean Square Error $\quad 0.123378$

Mean of Response 9.553333

Observations (or Sum Wgts)

Analysis of Variance $\begin{array}{lrrrrr}\text { Block } & 2 & 0.05526667 & 0.027633 & 1.8153 & 0.2418\end{array}$ $\begin{array}{llll}\text { Error } & 6 & 0.09133333 & 0.015222\end{array}$

Means for Oneway Anova

Level Number Mean Std Error Lower 95\% Upper 95\% $\begin{array}{llrrrr}1 & 3 & 9.44333 & 0.07123 & 9.2690 & 9.6176 \\ 2 & 3 & 9.59667 & 0.07123 & 9.4224 & 9.7710\end{array}$ $\begin{array}{llllll}2 & 3 & 9.59667 & 0.0723 & 9.4224 & 9.7710 \\ 3 & 3 & 9.62000 & 0.07123 & 9.4457 & 9.7943\end{array}$ Std Error uses a pooled estimate of error variance 


\section{Exhibit E3. Measurements of the Multi-Element Solution Standard by ICP-AES Block (continued)}

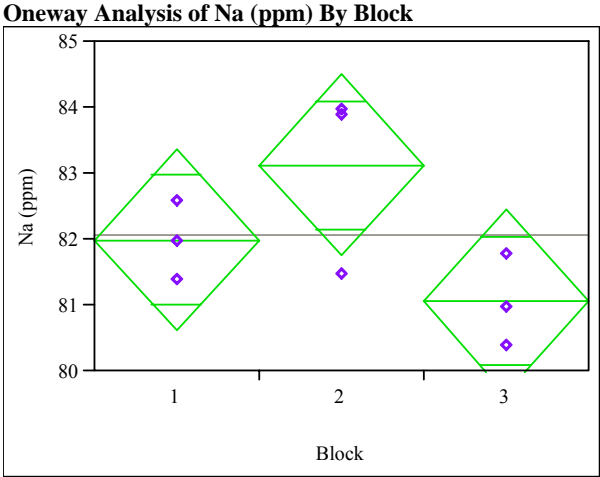

\section{Oneway Anova}

Summary of Fit

$\begin{array}{lr}\text { Rsquare } & 0.529379 \\ \text { Adj Rsquare } & 0.372506 \\ \text { Root Mean Square Error } & 0.975819 \\ \text { Mean of Response } & 82.06667 \\ \text { Observations (or Sum Wgts) } & 9\end{array}$

Analysis of Variance

Source DF Sum of Squares Mean Square F Ratio Prob > F $\begin{array}{lrrrrr}\text { Block } & 2 & 6.426667 & 3.21333 & 3.3746 & 0.1042\end{array}$ $\begin{array}{lrrr}\text { Error } & 6 & 5.713333 & 0.95222\end{array}$

C. Total $8 \quad 12.140000$

Means for Oneway Anova

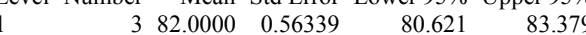

$\begin{array}{llllll}1 & 3 & 82.0000 & 0.56339 & 80.621 & 83.379 \\ 2 & 3 & 83.1333 & 0.56339 & 81.755 & 84.512 \\ 3 & 3 & 81.0667 & 0.56339 & 79.688 & 82.445\end{array}$

Std Error uses a pooled estimate of error variance

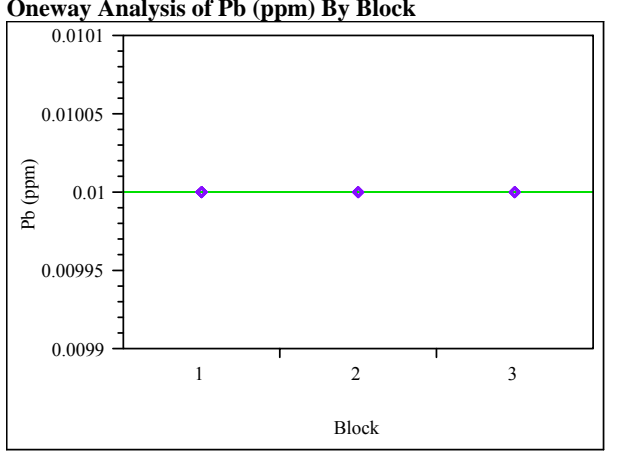

\section{Oneway Anova}

Summary of Fit

Rsquare

Adj Rsquare

Mean of Response

Observations (or Sum

Source DF Sum of Squares Mean Square F Ratio Prob $>$ F

Mean Square F Ratio Prob $>$

Error

C. Total 8

Means for Oneway Anova
Level Number Mean Std Error Lower 95\% Upper 95\%

Level Number Mean Std Error Lower 95\% Upper 95\%

$\begin{array}{llllll}1 & 3 & 0.010000 & 0 & 0.01000 & 0.01000 \\ 2 & 3 & 0.010000 & 0 & 0.01000 & 0.01000 \\ 3 & 3 & 0.010000 & 0 & 0.01000 & 0.0000\end{array}$

Std Error uses a pooled estimate of error vaimec
Oneway Analysis of Si (ppm) By Block

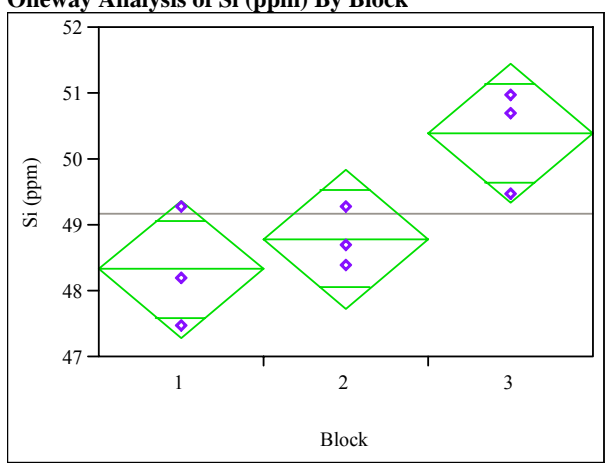

Oneway Anova

Summary of Fit

Rsquare

Adj Rsquare

0.679375

Root Mean Square Error $\quad \begin{array}{r}0.572499 \\ 0.7446\end{array}$

Mean of Response 49.17778

Observations (or Sum Wgts)

Analysis of Variance

Source DF Sum of Squares Mean Square F Ratio Prob > F $\begin{array}{llllll}\text { Block } & 2 & 7.048889 & 3.52444 & 6.3567 & 0.0330\end{array}$

$\begin{array}{lll}\text { Error } & 6 & 3.326667\end{array}$ 0.5544

$\begin{array}{lll}\text { C. Total } & 8 & 10.375556\end{array}$

Level Number Mean Std Error Lower 95\% Upper 95\% $\begin{array}{rrrrrr}1 & 3 & 48.3333 & 0.42990 & 47.281 & 49.385 \\ 1 & 3 & 48.8000 & 0.42990 & 47.748 & 49.852\end{array}$ $\begin{array}{llllll}2 & 3 & 48.8000 & 0.42990 & 47.748 & 49.852 \\ 3 & 3 & 50.4000 & 0.42990 & 49.348 & 51.452\end{array}$ Std Error uses a pooled estimate of error variance 
Exhibit E3. Measurements of the Multi-Element Solution Standard by ICP-AES Block (continued)

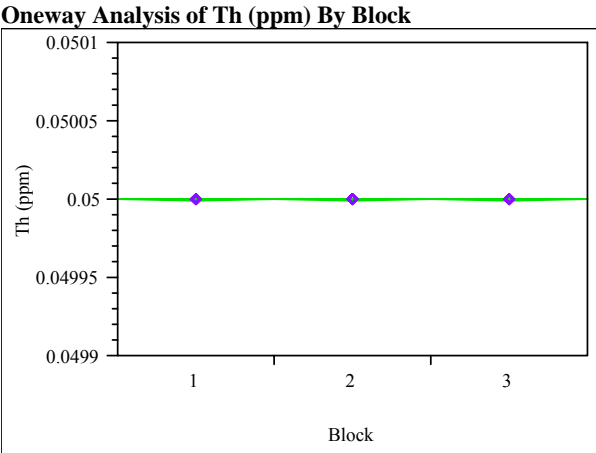

Oneway Anova

Summary of Fit

$\begin{array}{lr}\text { Rsquare } & 0 \\ \text { Adj Rsquare } & -0.33333\end{array}$

Root Mean Square Error $\quad 8.5 \mathrm{e}-18$

Mean of Response

Observations (or Sum Wgts)

Analysis of Variance

Source DF Sum of Squares Mean Square F Ratio Prob $>$ F

Block $\quad 2 \quad r \begin{array}{rrrr}0 & 0 & 0.0000 & 1.0000\end{array}$

$\begin{array}{llll}\text { Error } & 6 & 4.3333 \mathrm{e}-34 & 7.222 \mathrm{e}-35\end{array}$

$8 \quad 4.3333 \mathrm{e}-34$

Means for Oneway Anova

Level Number Mean Std Error Lower 95\% Upper 95\%

$\begin{array}{llllll}1 & 3 & 0.050000 & 4.907 \mathrm{e}-18 & 0.05000 & 0.05000\end{array}$

$\begin{array}{llllll}1 & 3 & 0.050000 & 4.907 \mathrm{e}-18 & 0.05000 & 0.05000 \\ 2 & 3 & 0.050000 & 4.907 \mathrm{e}-18 & 0.05000 & 0.05000\end{array}$

$\begin{array}{llllll}1 & 3 & 0.050000 & 4.907 \mathrm{e}-18 & 0.05000 & 0.05000 \\ 3 & 3 & 0.050000 & 4.907 \mathrm{e}-18 & 0.05000 & 0.05000\end{array}$

Std Error uses a pooled estimate of error variance

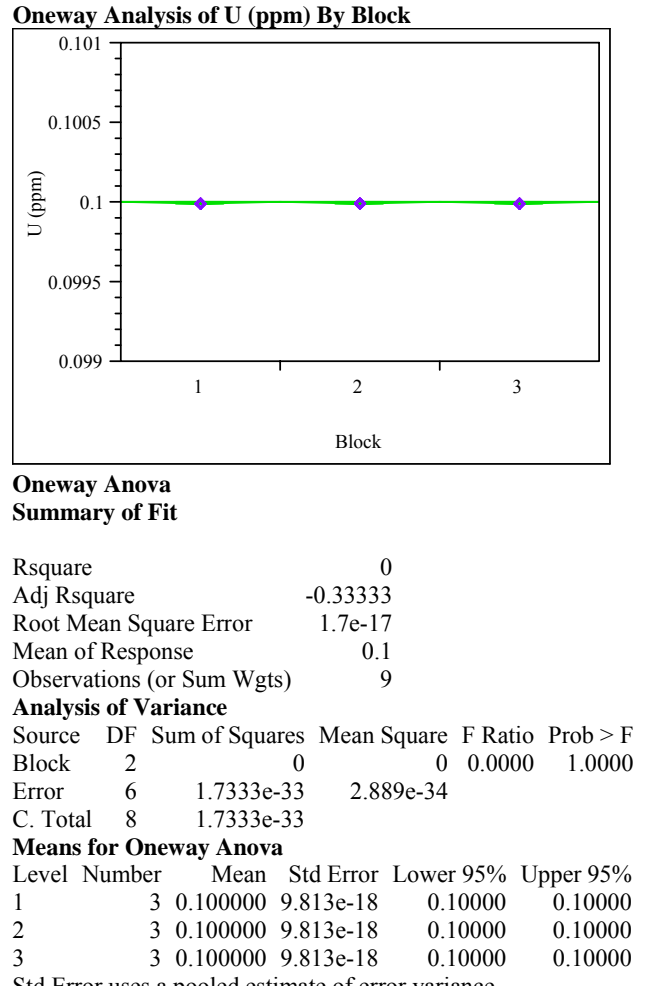

Std Error uses a pooled estimate of error variance 
Exhibit E4. Laboratory PCT Measurements by Glass Number for Study Glasses and Standards

(100 - Solution Standard; 101 - EA; 102 - ARM; 103 - Blanks)

B (ppm) By Glass \#

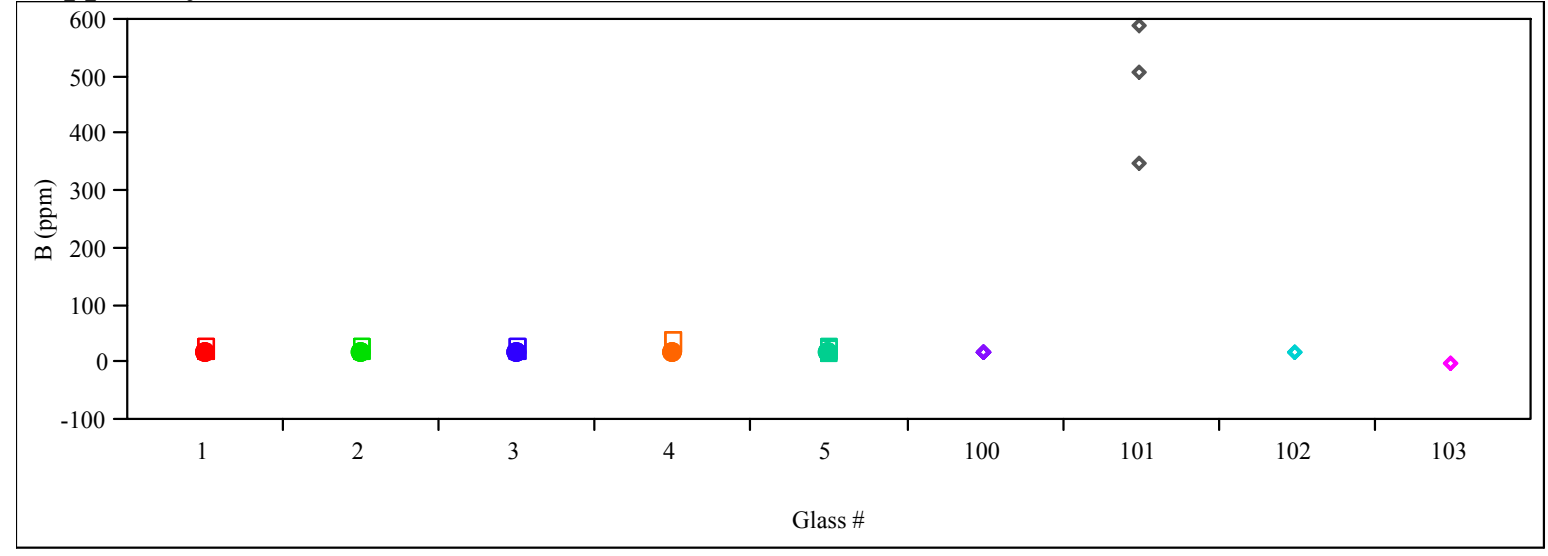

Ba (ppm) By Glass \#

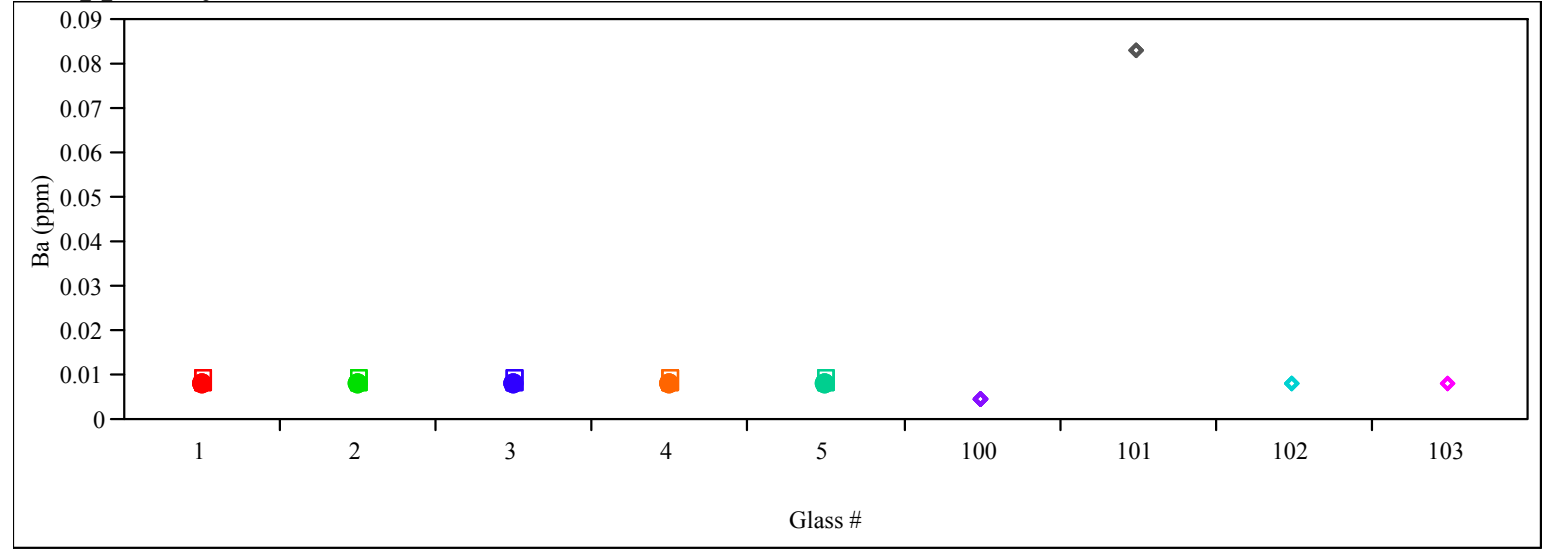

Cd (ppm) By Glass \#

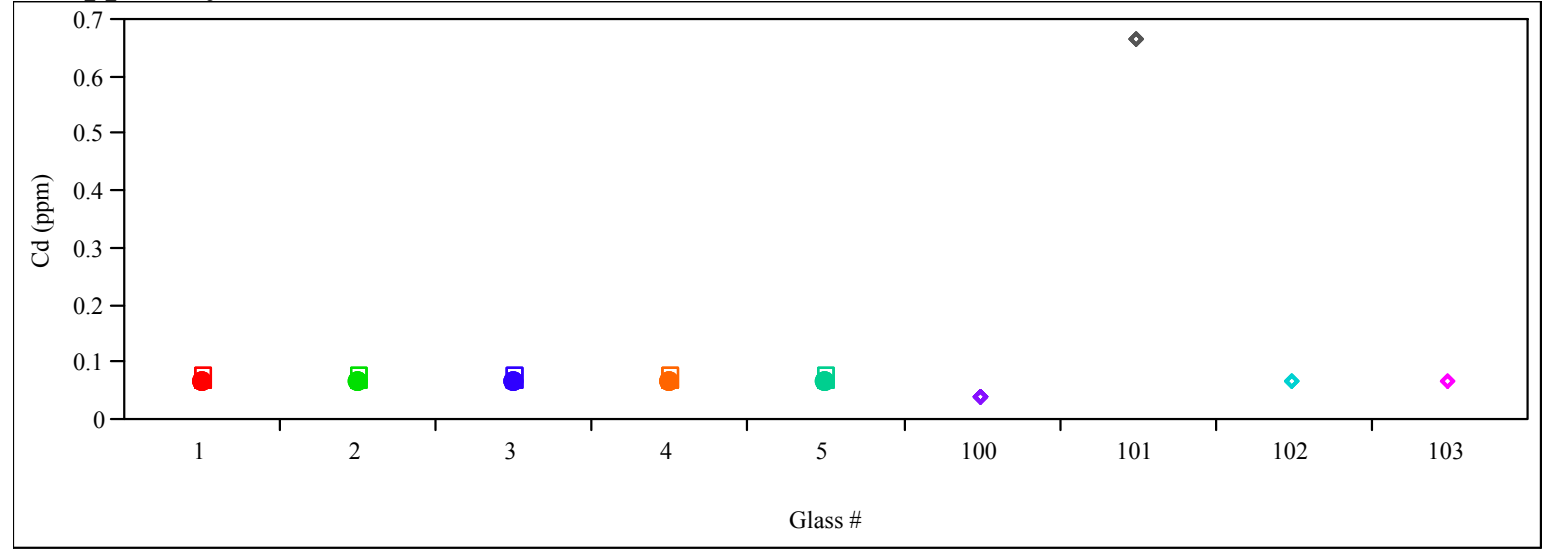


Exhibit E4. Laboratory PCT Measurements by Glass Number

for Study Glasses and Standards (continued)

(100 - Solution Standard; 101 - EA; 102 - ARM; 103 - Blanks)

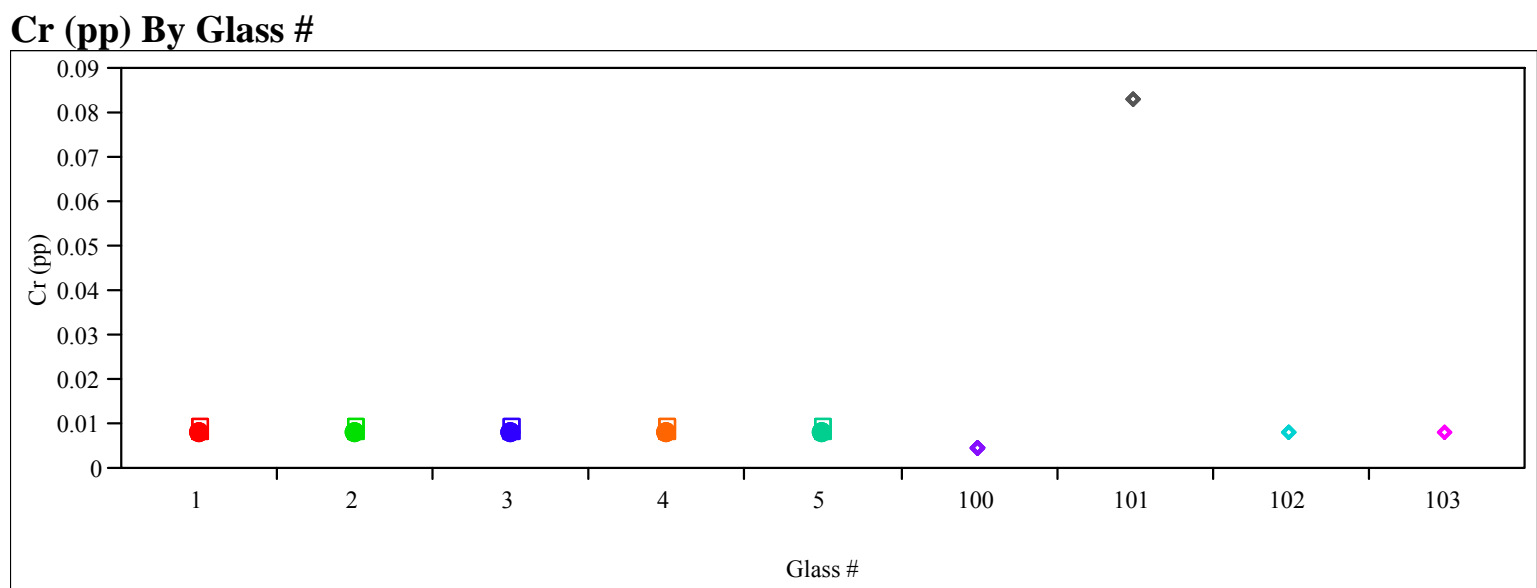

Fe (ppm) By Glass \#

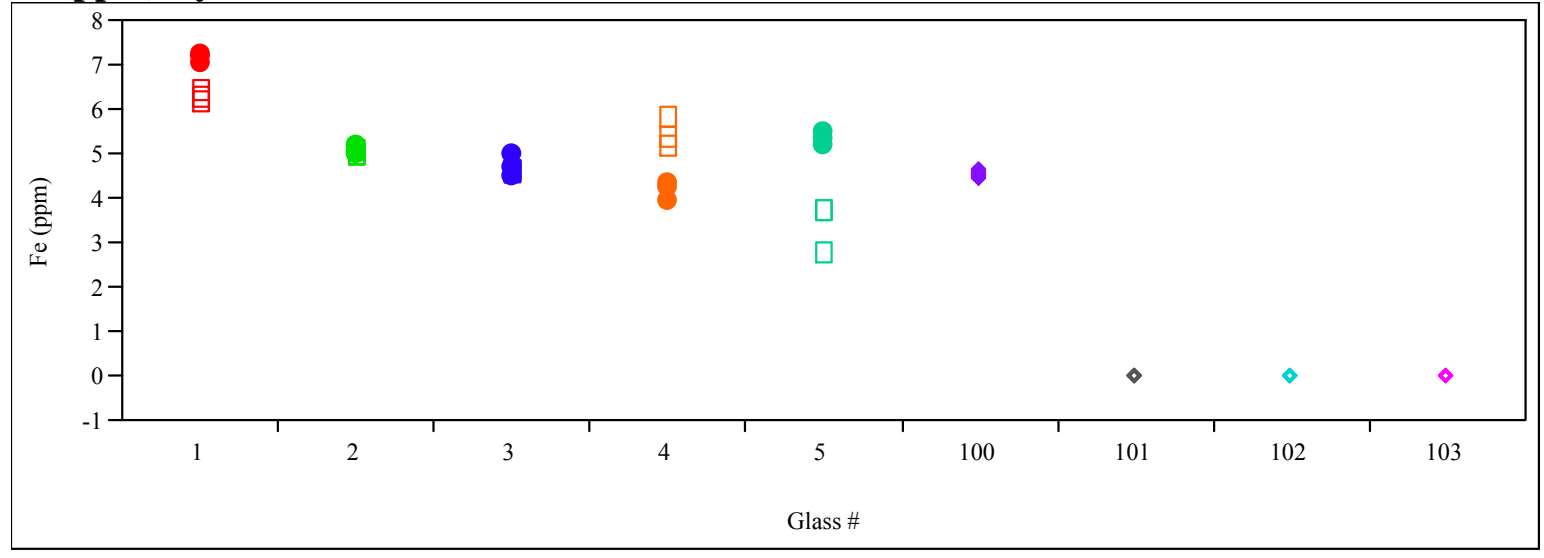

Li (ppm) By Glass \#

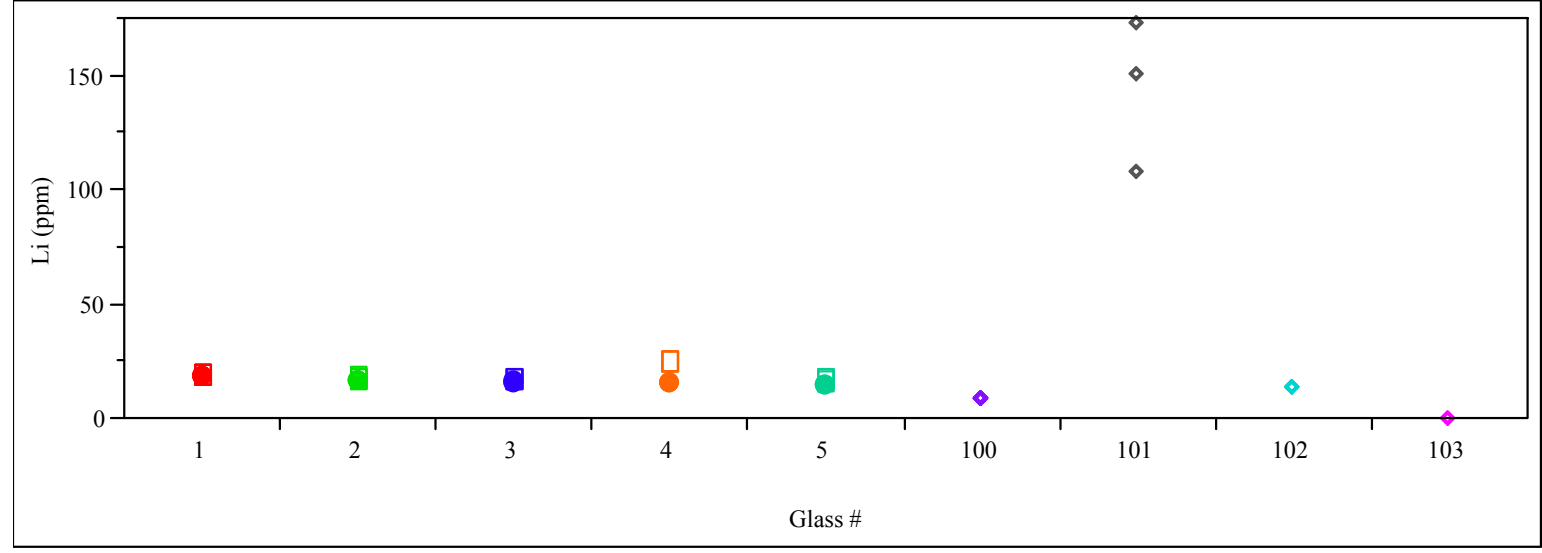


Exhibit E4. Laboratory PCT Measurements by Glass Number

for Study Glasses and Standards (continued)

(100 - Solution Standard; 101 - EA; 102 - ARM; 103 - Blanks)

Na (ppm) By Glass \#

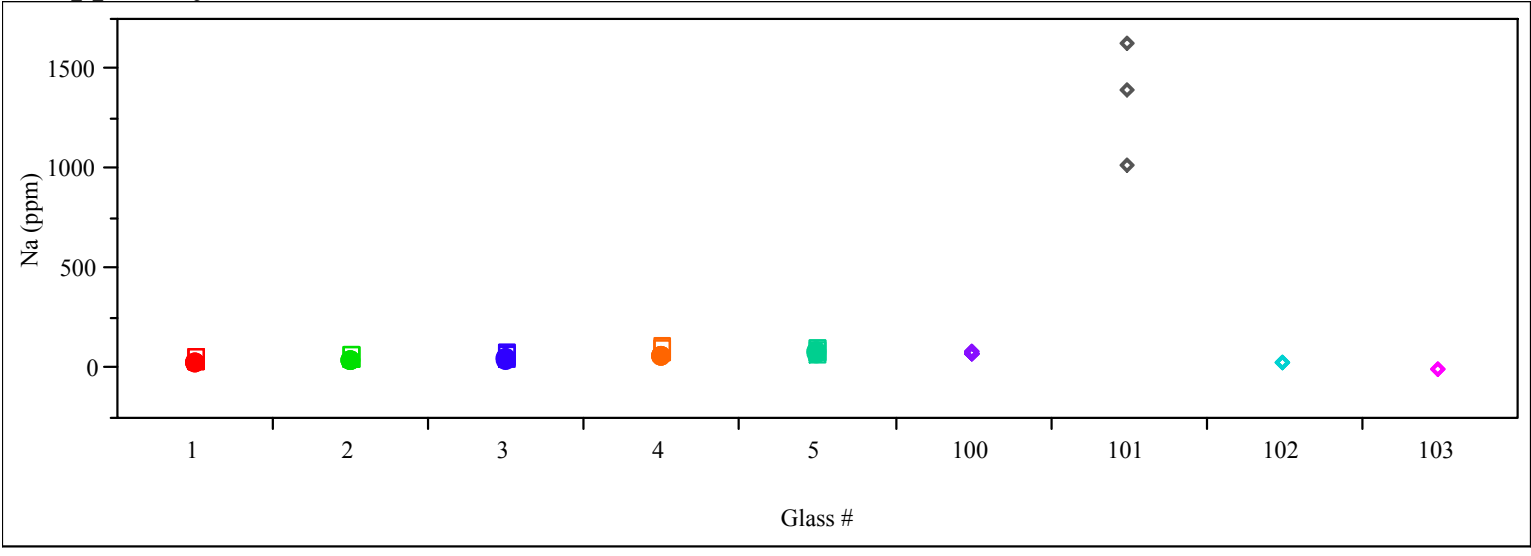

Pb (ppm) By Glass \#

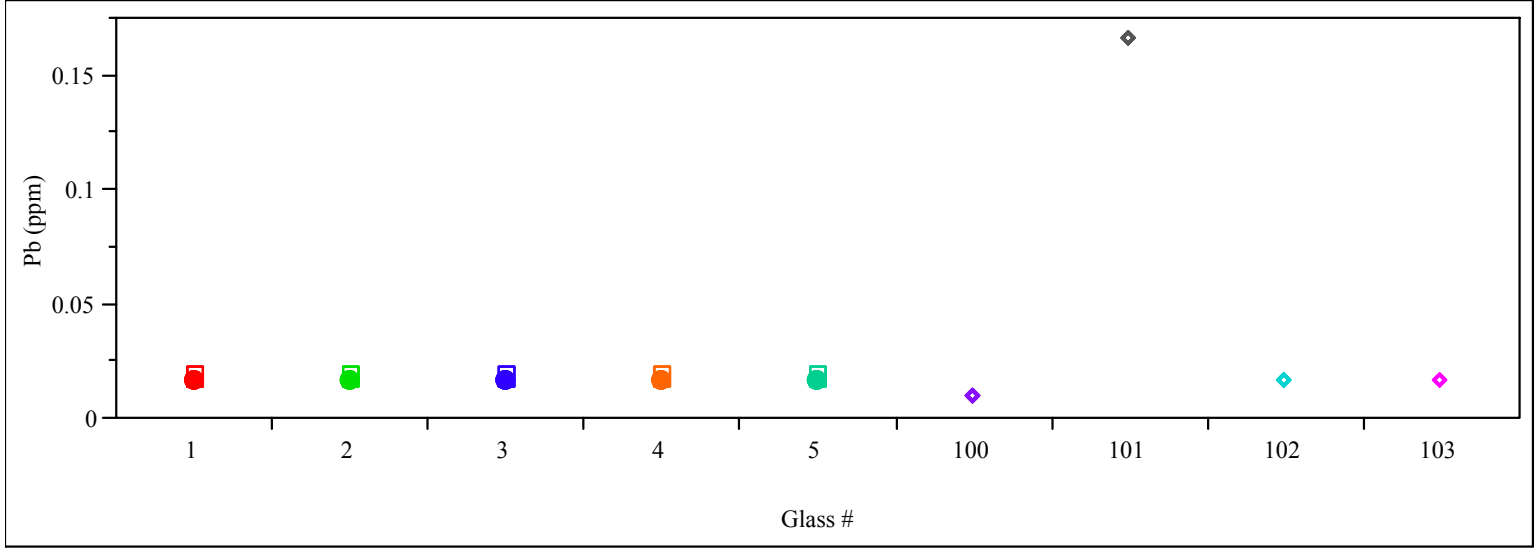

Si (ppm) By Glass \#

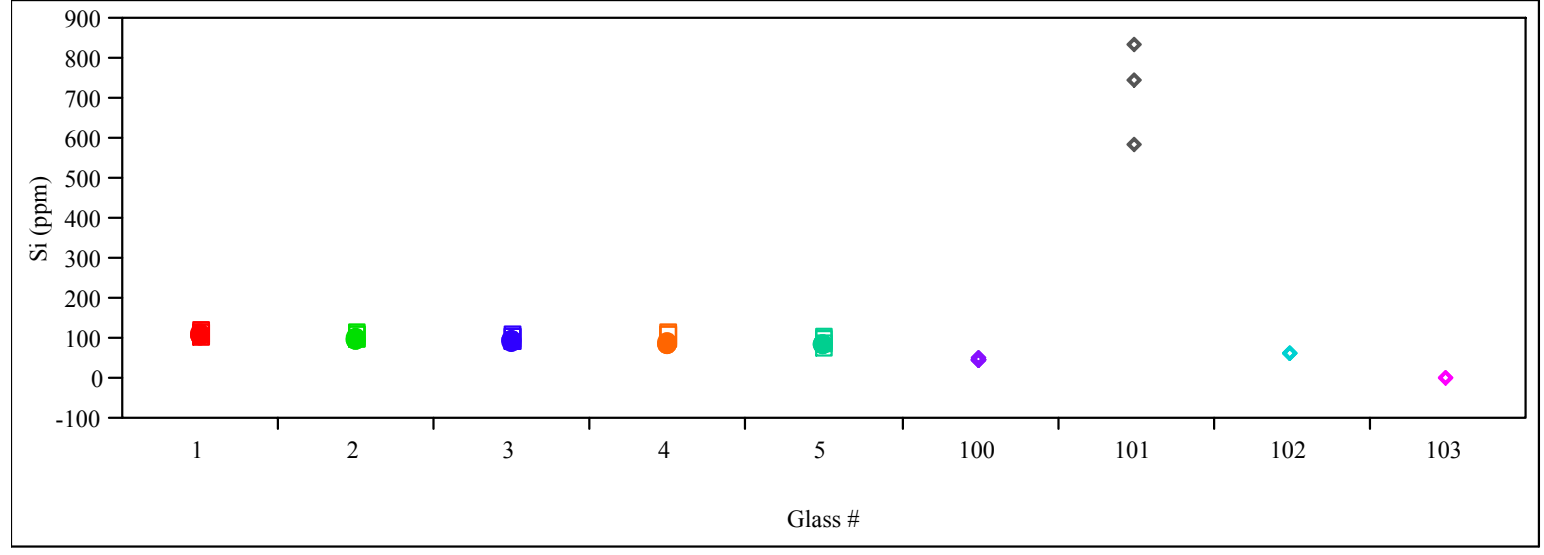


Exhibit E4. Laboratory PCT Measurements by Glass Number

for Study Glasses and Standards (continued)

(100 - Solution Standard; 101 - EA; 102 - ARM; 103 - Blanks)

Th (ppm) By Glass \#

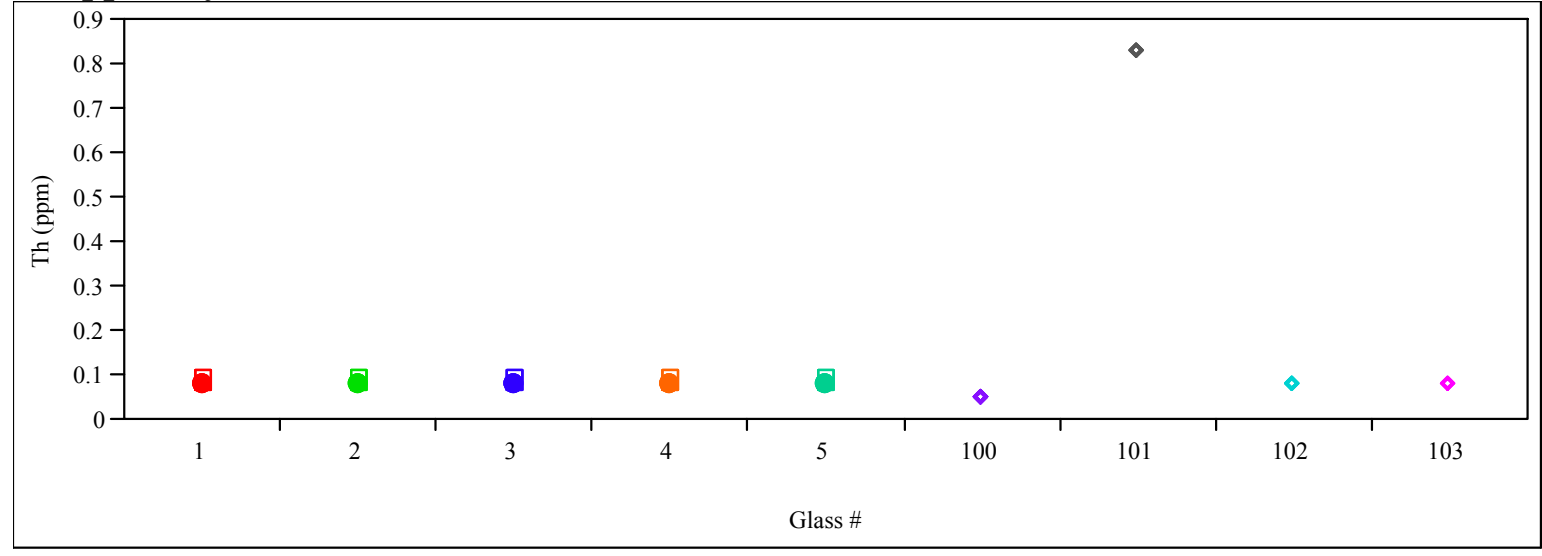

U (ppm) By Glass \#

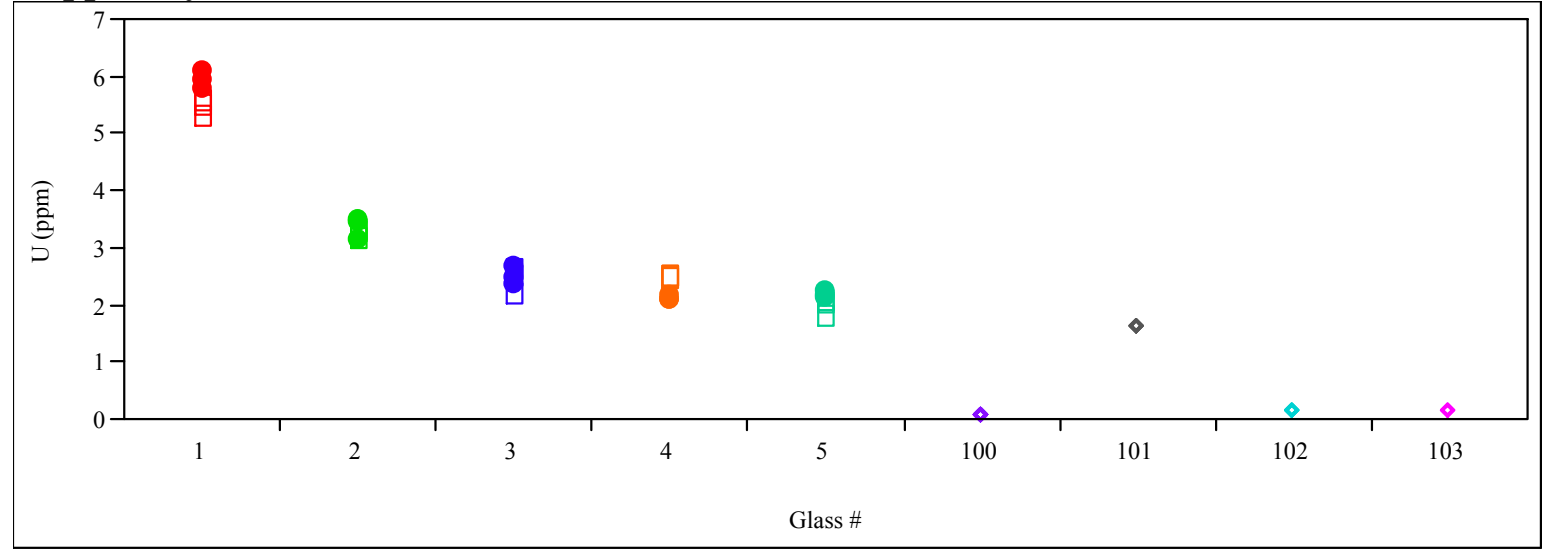


Exhibit E5. Laboratory PCT Measurements by Glass Number for Study Glasses

B (ppm) By Glass \#

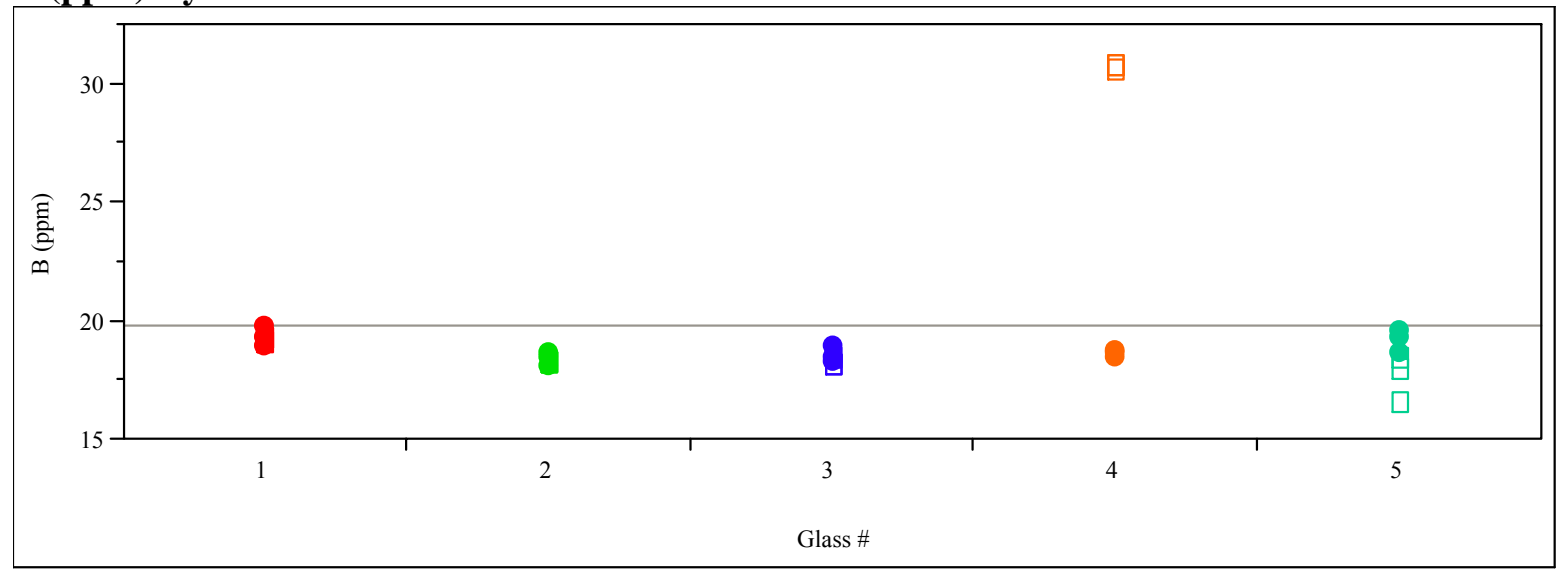

Ba (ppm) By Glass \#

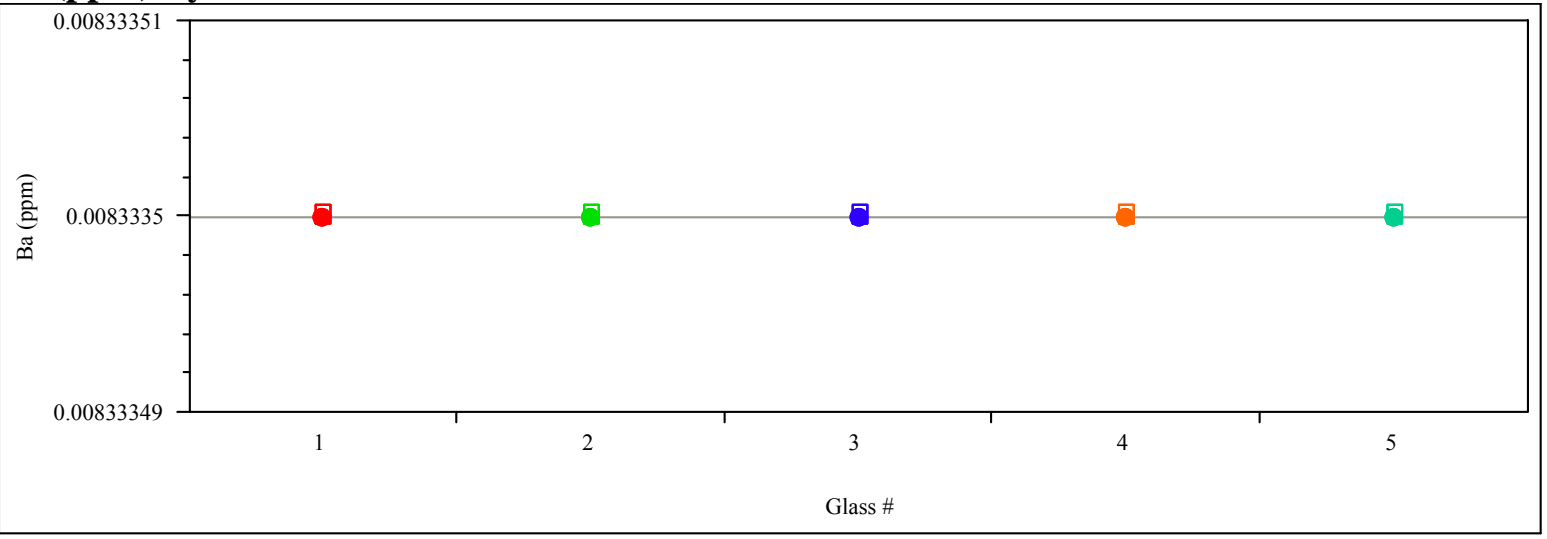

Cd (ppm) By Glass \#

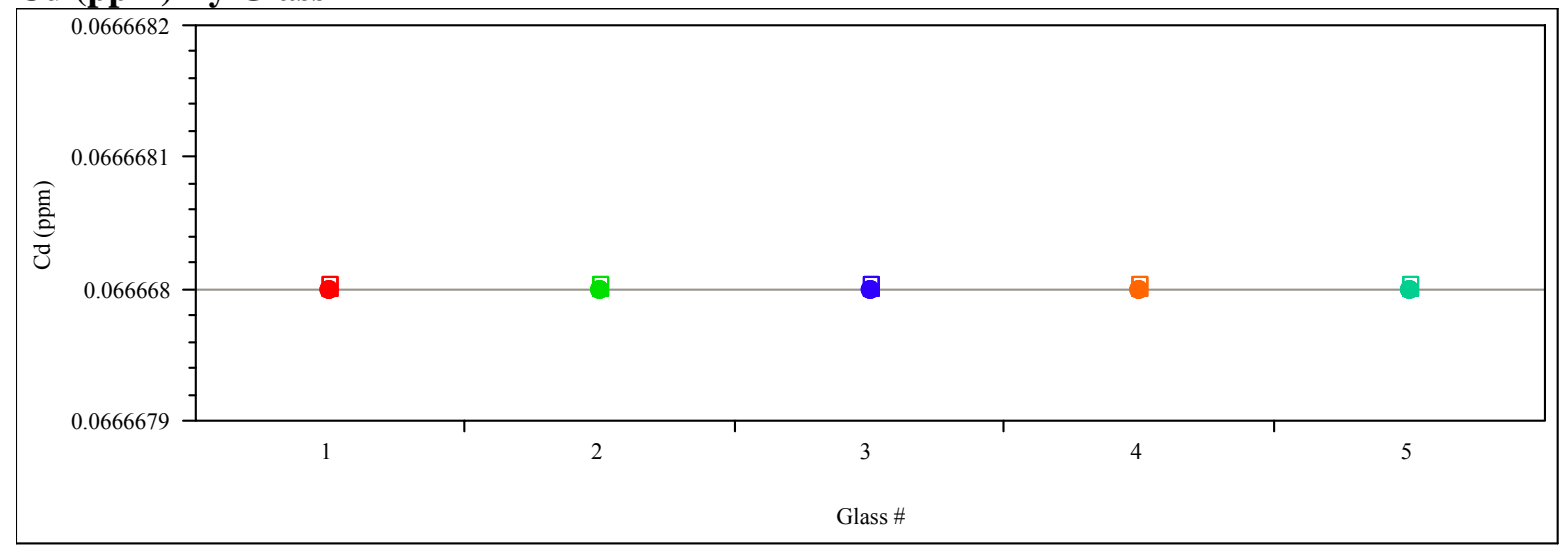


Exhibit E5. Laboratory PCT Measurements by Glass Number for Study Glasses (continued)

Cr (pp) By Glass \#

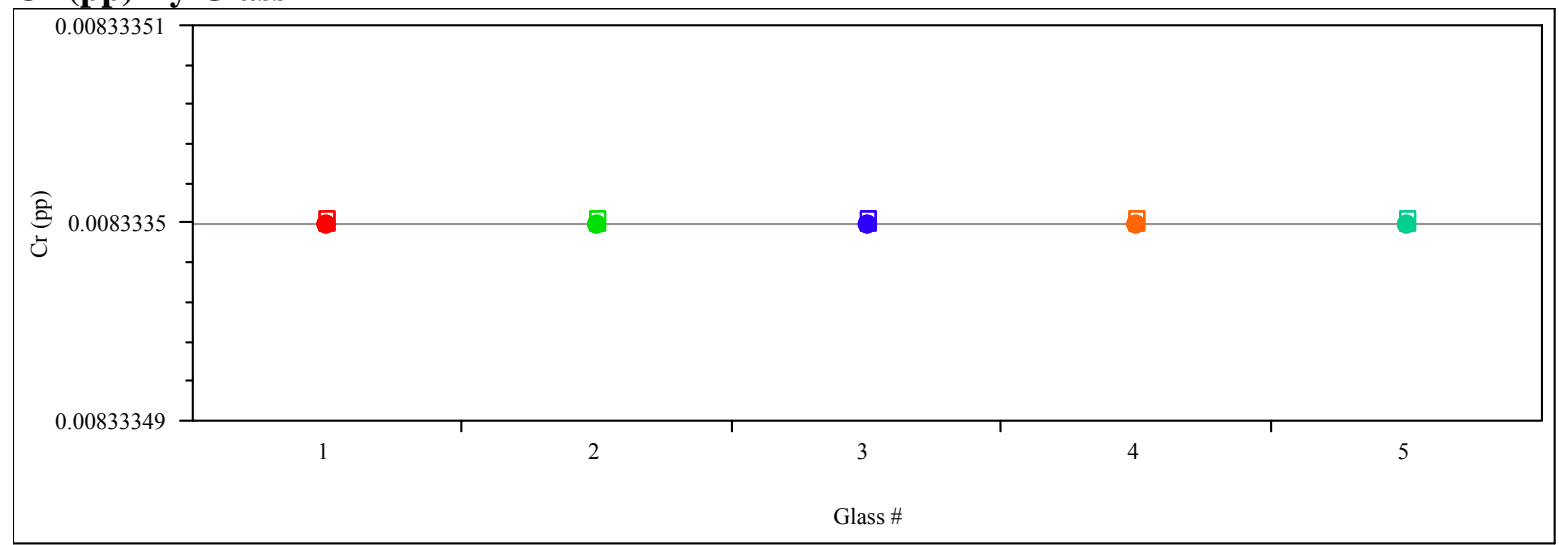

Fe (ppm) By Glass \#

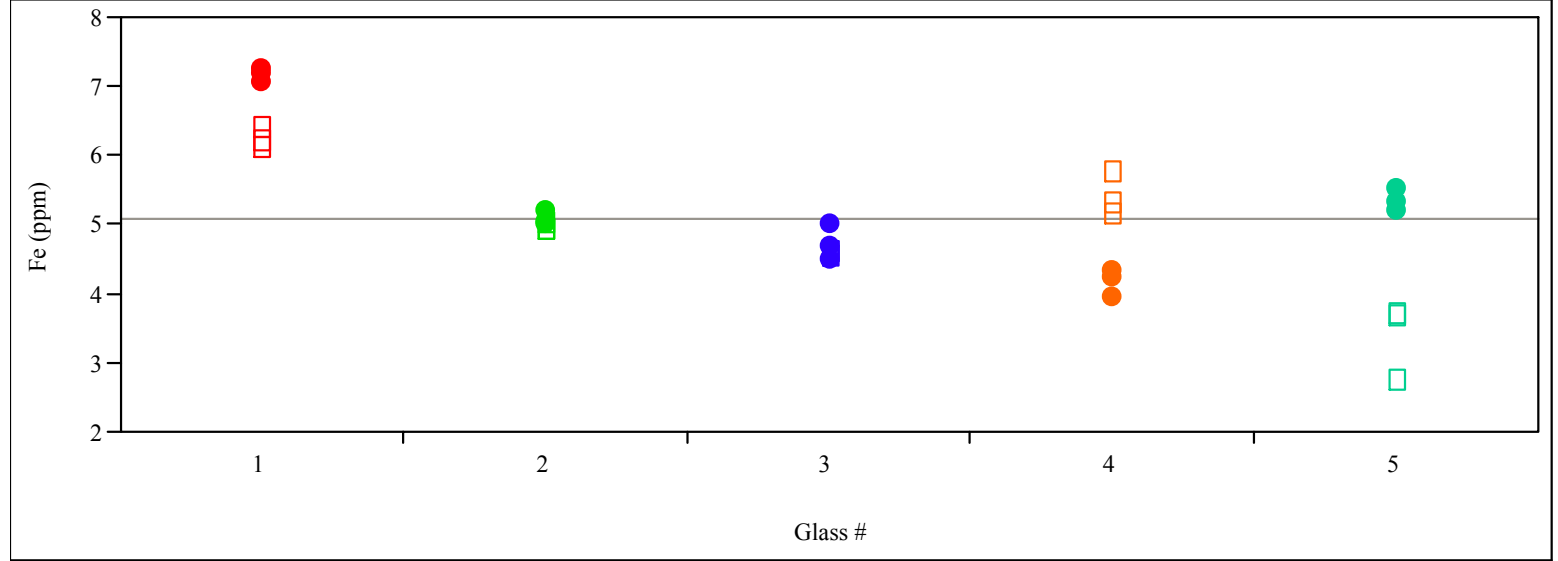

Li (ppm) By Glass \#

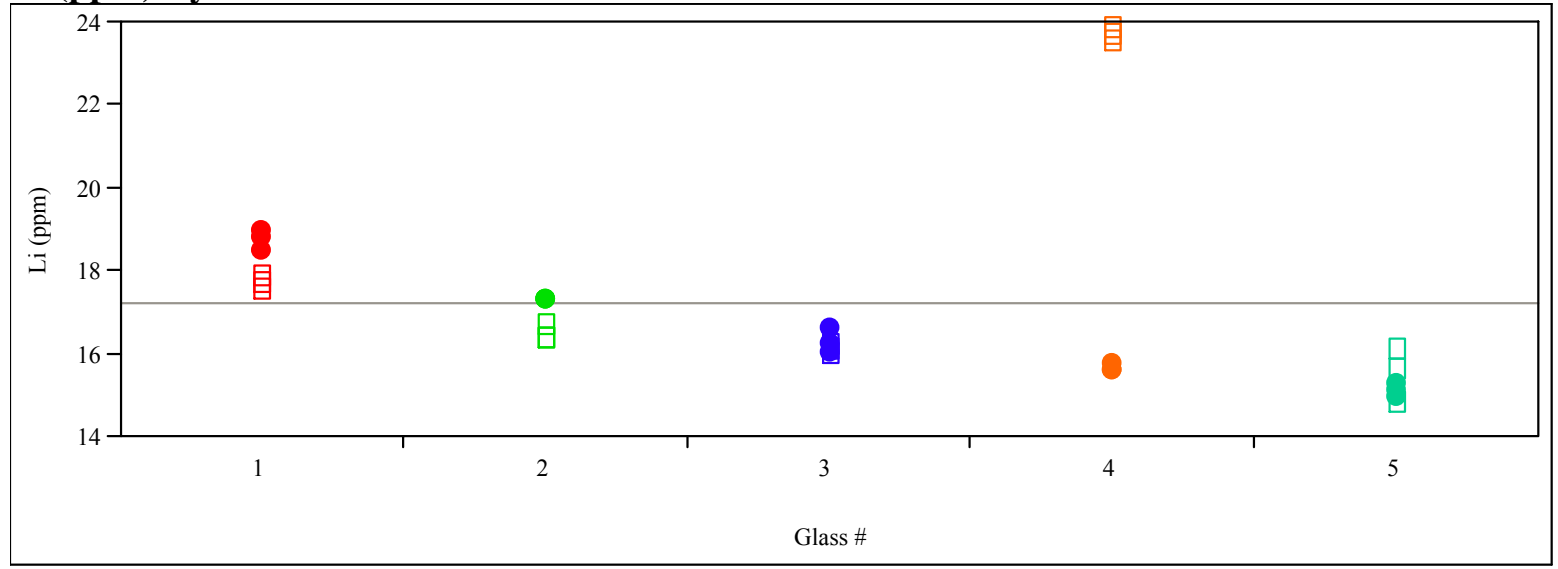


Exhibit E5. Laboratory PCT Measurements by Glass Number for Study Glasses (continued)

Na (ppm) By Glass \#

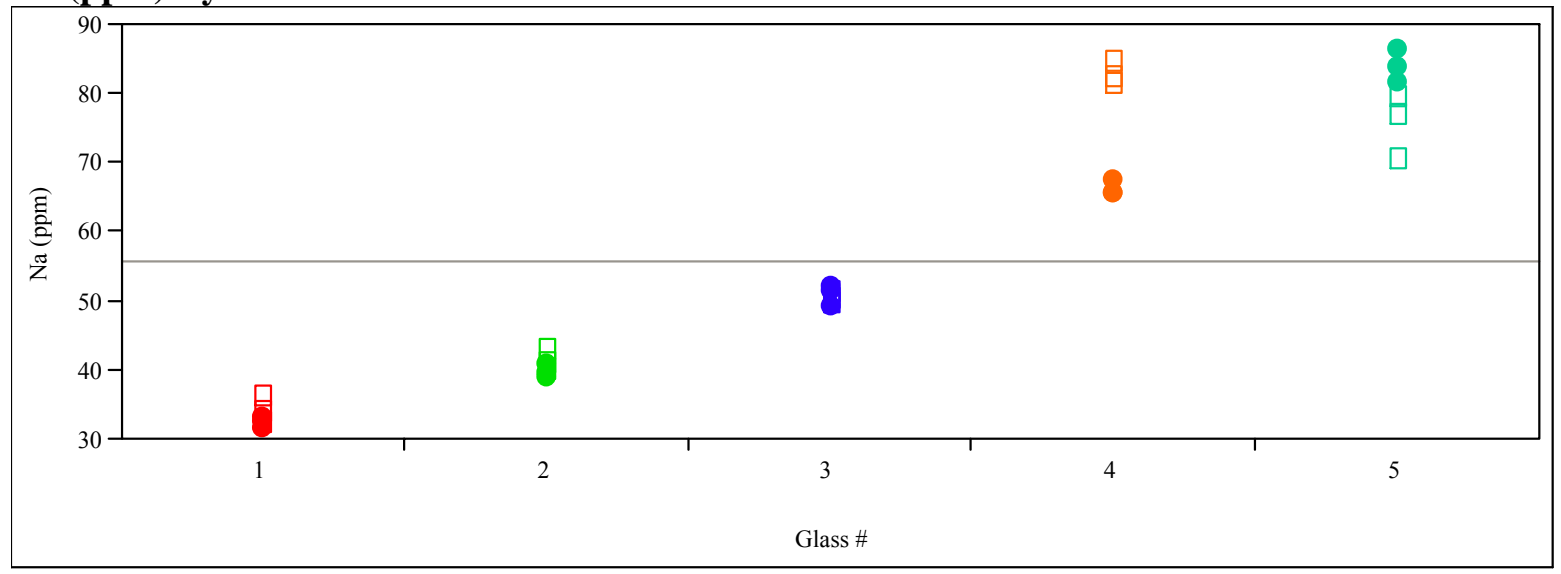

Pb (ppm) By Glass \#

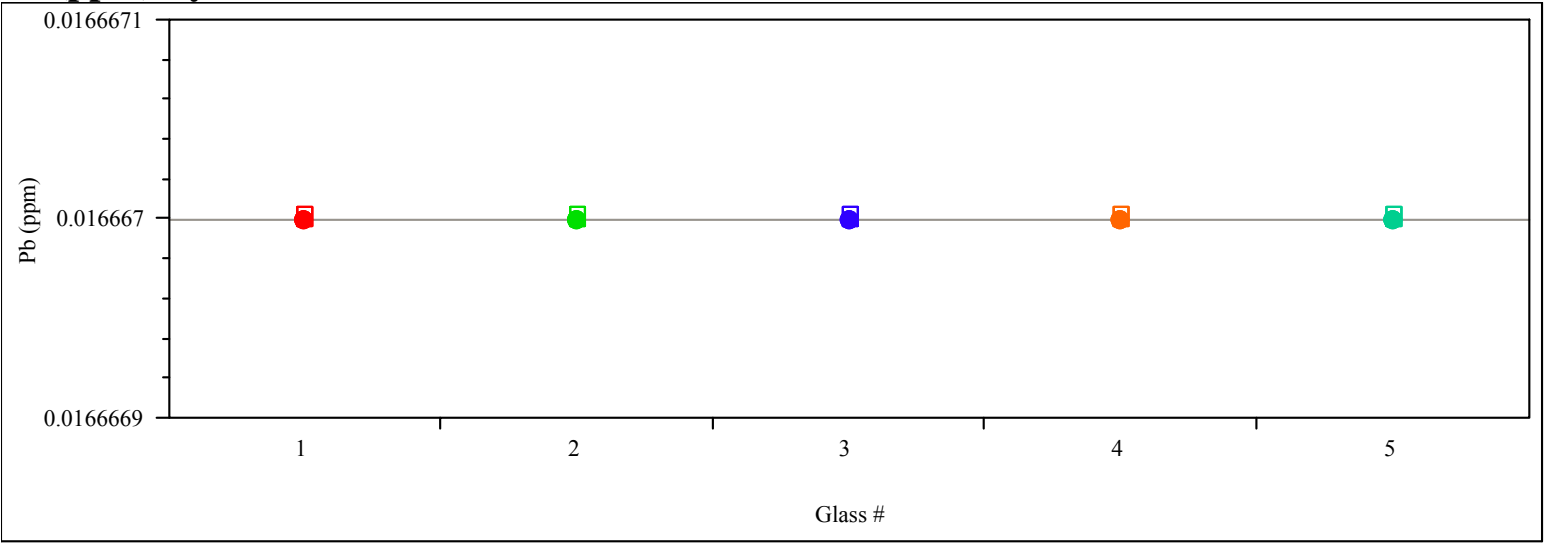

\section{Si (ppm) By Glass \#}

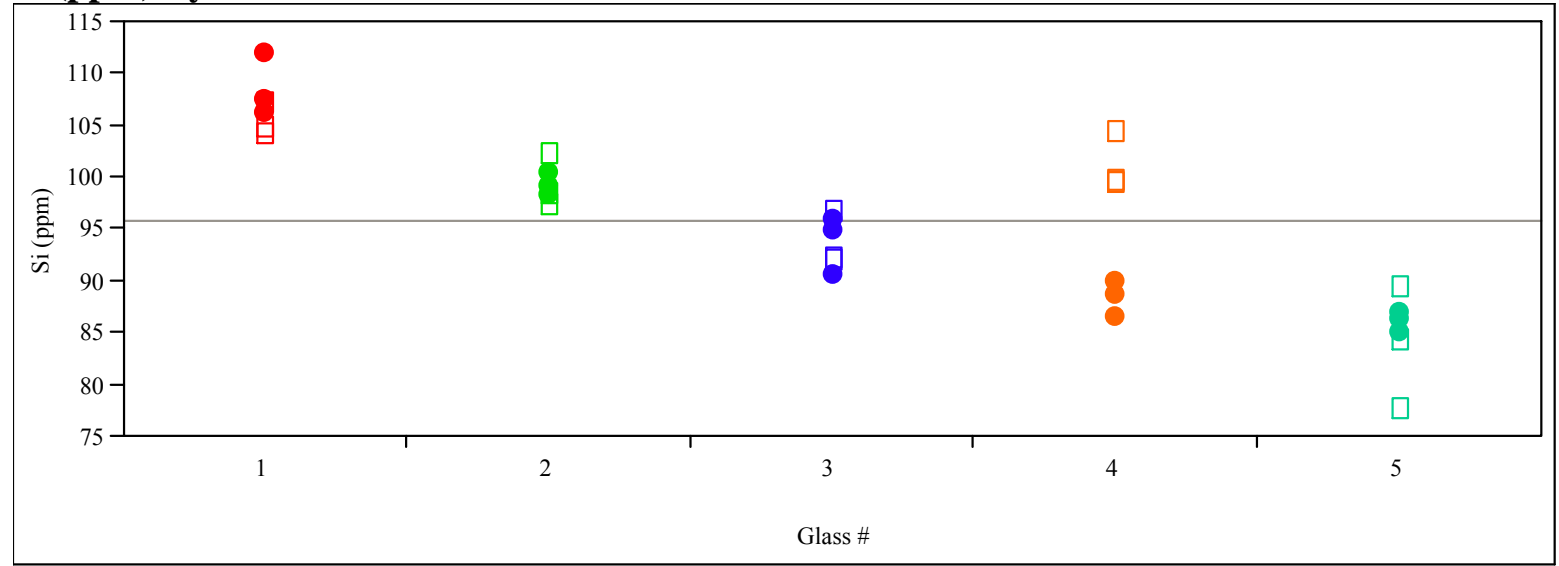


Exhibit E5. Laboratory PCT Measurements by Glass Number for Study Glasses (continued)

Th (ppm) By Glass \#

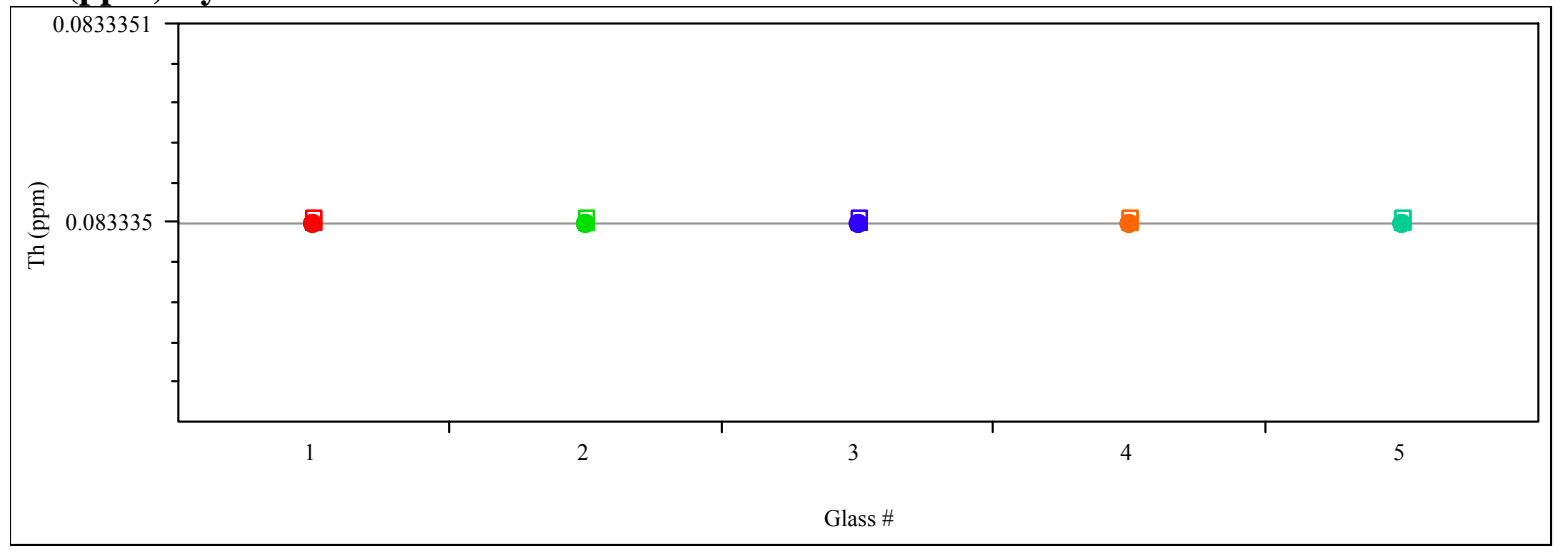

U (ppm) By Glass \#

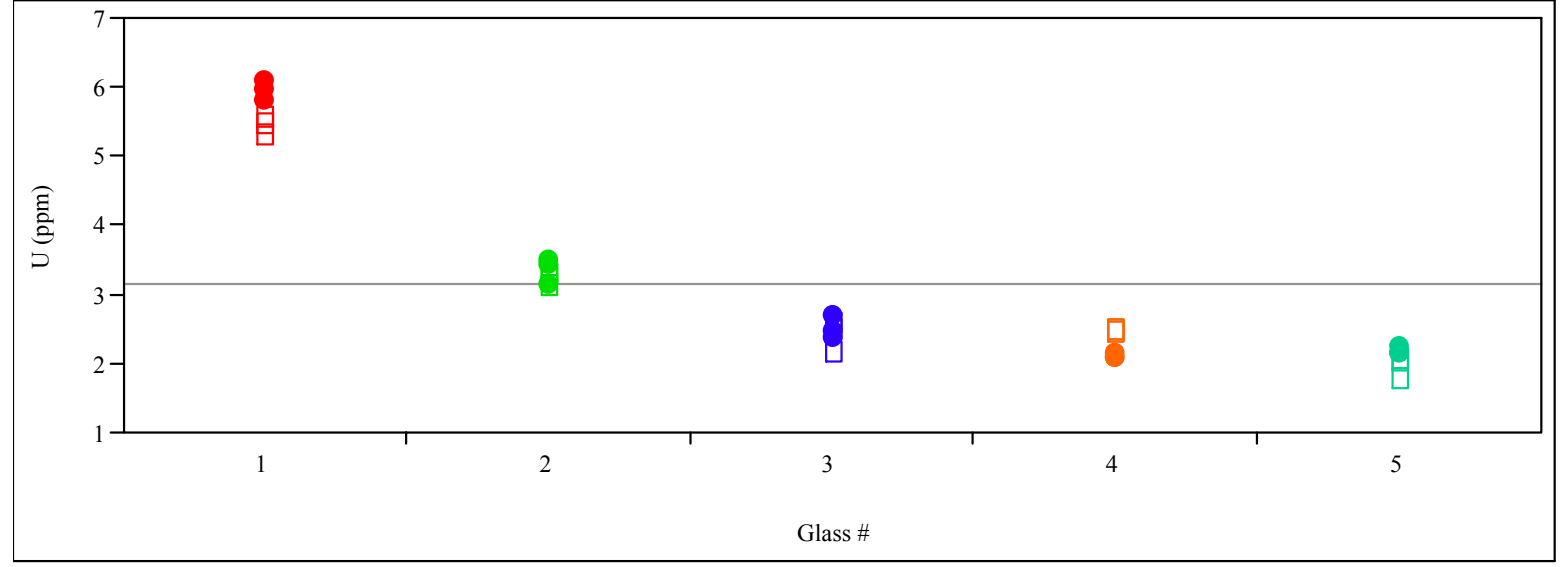




\section{Exhibit E6. Correlations and Scatter Plots of Normalized PCTs Over All Compositional Views and Heat Treatments}

\section{Comp/HT=measured bc-ccc}

\section{Correlations}

$\begin{array}{lrrrr} & \log \mathrm{NL}[\mathrm{B}(\mathrm{g} / \mathrm{L})] & \log \mathrm{NL}[\mathrm{Li}(\mathrm{g} / \mathrm{L})] & \log \mathrm{NL}[\mathrm{Na}(\mathrm{g} / \mathrm{L})] & \log \mathrm{NL}[\mathrm{Si}(\mathrm{g} / \mathrm{L})] \\ \log \mathrm{NL}[\mathrm{B}(\mathrm{g} / \mathrm{L})] & 1.0000 & 0.9990 & 0.9299 & 0.9959 \\ \log \mathrm{NL}[\mathrm{Li}(\mathrm{g} / \mathrm{L})] & 0.9990 & 1.0000 & 0.9378 & 0.9987 \\ \log \mathrm{NL}[\mathrm{Na}(\mathrm{g} / \mathrm{L})] & 0.9299 & 0.9378 & 1.0000 & 0.9369 \\ \log \mathrm{NL}[\mathrm{Si}(\mathrm{g} / \mathrm{L})] & 0.9959 & 0.9987 & 0.9369 & 1.0000\end{array}$

\section{Scatterplot Matrix}

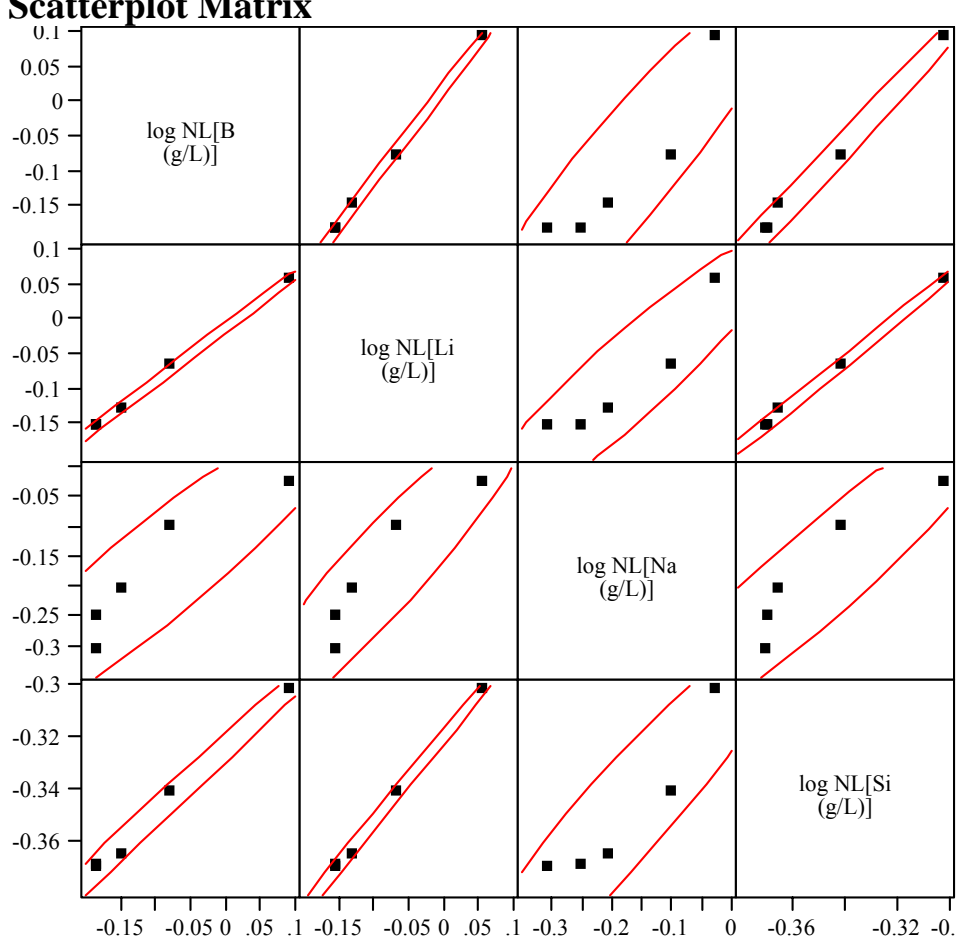

\section{Comp/HT=measured bc-quenched}

\section{Correlations}

$\log \mathrm{NL}[\mathrm{B}(\mathrm{g} / \mathrm{L})] \log \mathrm{NL}[\mathrm{Li}(\mathrm{g} / \mathrm{L})] \log \mathrm{NL}[\mathrm{Na}(\mathrm{g} / \mathrm{L})] \log \mathrm{NL}[\mathrm{Si}(\mathrm{g} / \mathrm{L})]$ $\begin{array}{lllll}\log \mathrm{NL}[\mathrm{B}(\mathrm{g} / \mathrm{L})] & 1.0000 & 0.9497 & 0.9354 & 0.8839 \\ \log \mathrm{NL}[\mathrm{Li}(\mathrm{g} / \mathrm{L})] & 0.9497 & 1.0000 & 0.7925 & 0.9668\end{array}$ $\begin{array}{lllll}\log \mathrm{NL}[\mathrm{Na}(\mathrm{g} / \mathrm{L})] & 0.9354 & 0.7925 & 1.0000 & 0.6810\end{array}$ $\begin{array}{lllll}\log \mathrm{NL}[\mathrm{Si}(\mathrm{g} / \mathrm{L})] & 0.8839 & 0.9668 & 0.6810 & 1.0000\end{array}$

\section{Scatterplot Matrix}

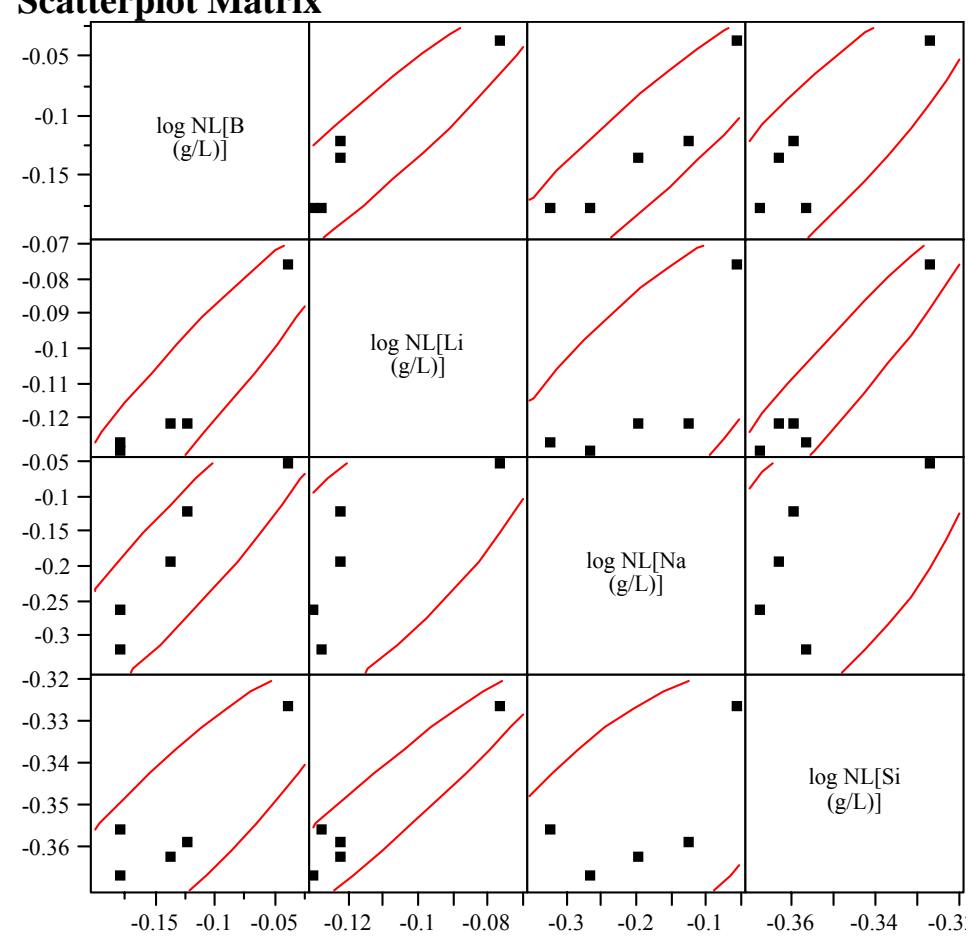


Exhibit E6. Correlations and Scatter Plots of Normalized PCTs Over All Compositional Views and Heat Treatments (continued)

\section{Comp/HT=measured-ccc}

\section{Multivariate}

\section{Correlations}

$\begin{array}{lrrrr} & \log \mathrm{NL}[\mathrm{B}(\mathrm{g} / \mathrm{L})] & \log \mathrm{NL}[\mathrm{Li}(\mathrm{g} / \mathrm{L})] & \log \mathrm{NL}[\mathrm{Na}(\mathrm{g} / \mathrm{L})] & \log \mathrm{NL}[\mathrm{Si}(\mathrm{g} / \mathrm{L})] \\ \log \mathrm{NL}[\mathrm{B}(\mathrm{g} / \mathrm{L})] & 1.0000 & 0.9990 & 0.9300 & 0.9959 \\ \log \mathrm{NL}[\mathrm{Li}(\mathrm{g} / \mathrm{L})] & 0.9990 & 1.0000 & 0.9378 & 0.9986 \\ \log \mathrm{NL}[\mathrm{Na}(\mathrm{g} / \mathrm{L})] & 0.9300 & 0.9378 & 1.0000 & 0.9368 \\ \log \mathrm{NL}[\mathrm{Si}(\mathrm{g} / \mathrm{L})] & 0.9959 & 0.9986 & 0.9368 & 1.0000\end{array}$

\section{Scatterplot Matrix}

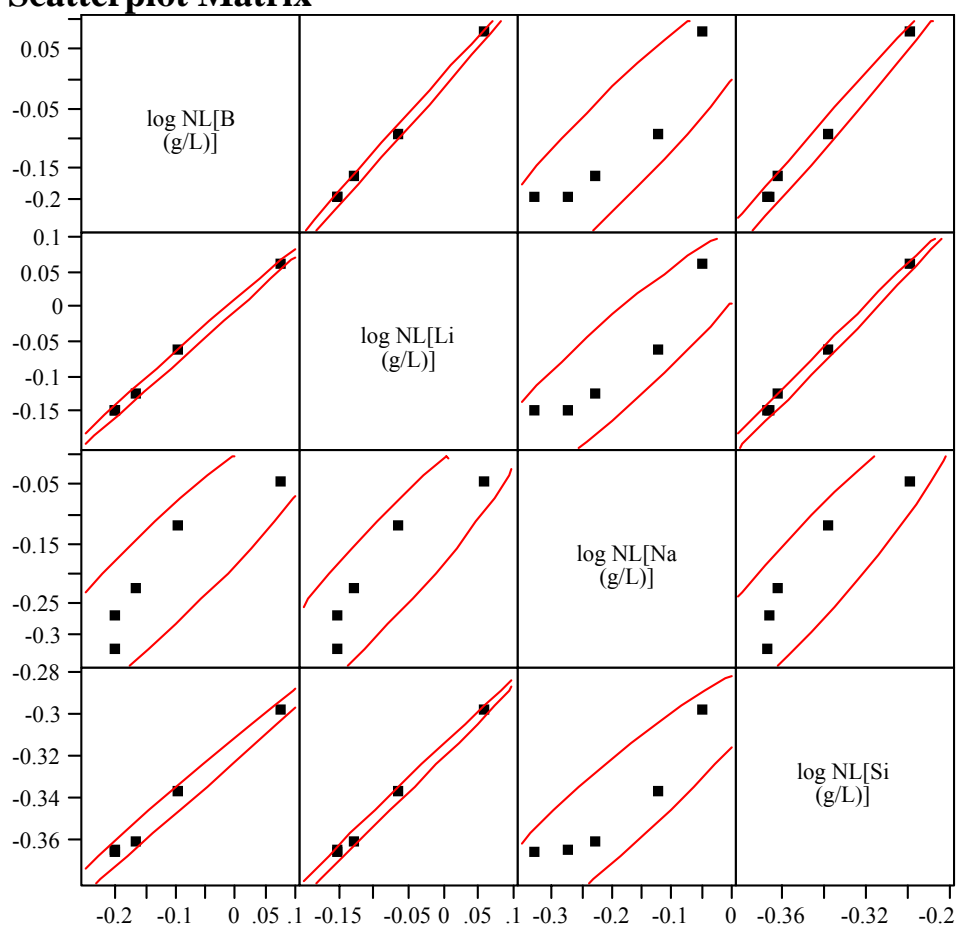

\section{Comp/HT=measured-quenched}

\section{Multivariate}

\section{Correlations}

$\begin{array}{lrrrr} & \log \mathrm{NL}[\mathrm{B}(\mathrm{g} / \mathrm{L})] & \log \mathrm{NL}[\mathrm{Li}(\mathrm{g} / \mathrm{L})] & \log \mathrm{NL}[\mathrm{Na}(\mathrm{g} / \mathrm{L})] & \log \mathrm{NL}[\mathrm{Si}(\mathrm{g} / \mathrm{L})] \\ \log \mathrm{NL}[\mathrm{B}(\mathrm{g} / \mathrm{L})] & 1.0000 & 0.9498 & 0.9353 & 0.8840 \\ \log \mathrm{NL}[\mathrm{Li}(\mathrm{g} / \mathrm{L})] & 0.9498 & 1.0000 & 0.7924 & 0.9666 \\ \log \mathrm{NL}[\mathrm{Na}(\mathrm{g} / \mathrm{L})] & 0.9353 & 0.7924 & 1.0000 & 0.6810 \\ \log \mathrm{NL}[\mathrm{Si}(\mathrm{g} / \mathrm{L})] & 0.8840 & 0.9666 & 0.6810 & 1.0000\end{array}$

\section{Scatterplot Matrix}

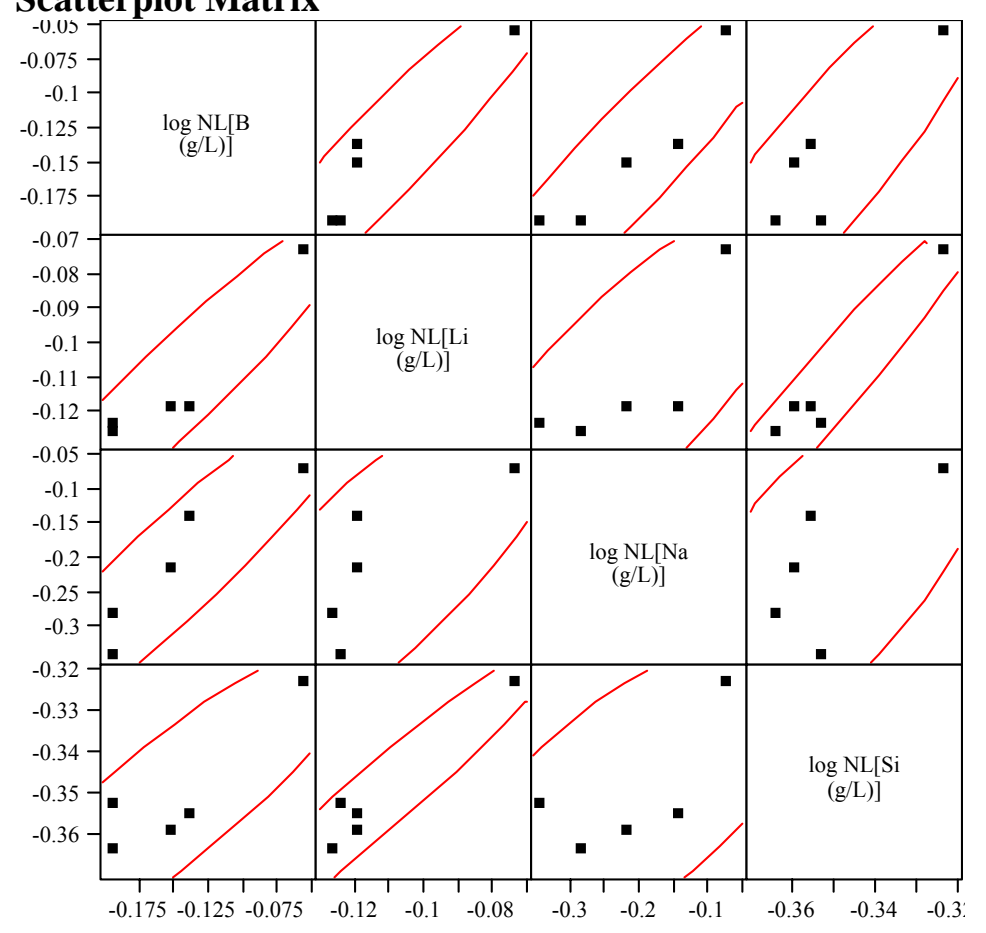


Exhibit E6. Correlations and Scatter Plots of Normalized PCTs

Over All Compositional Views and Heat Treatments (continued)

\section{Comp/HT=targeted-ccc}

\section{Multivariate}

\section{Correlations}

$\begin{array}{lrrrr} & \log \mathrm{NL}[\mathrm{B}(\mathrm{g} / \mathrm{L})] & \log \mathrm{NL}[\mathrm{Li}(\mathrm{g} / \mathrm{L})] & \log \mathrm{NL}[\mathrm{Na}(\mathrm{g} / \mathrm{L})] & \log \mathrm{NL}[\mathrm{Si}(\mathrm{g} / \mathrm{L})] \\ \log \mathrm{NL}[\mathrm{B}(\mathrm{g} / \mathrm{L})] & 1.0000 & 0.9984 & 0.9221 & 0.9972 \\ \log \mathrm{NL}[\mathrm{Li}(\mathrm{g} / \mathrm{L})] & 0.9984 & 1.0000 & 0.9314 & 0.9990 \\ \log \mathrm{NL}[\mathrm{Na}(\mathrm{g} / \mathrm{L})] & 0.9221 & 0.9314 & 1.0000 & 0.9418 \\ \log \mathrm{NL}[\mathrm{Si}(\mathrm{g} / \mathrm{L})] & 0.9972 & 0.9990 & 0.9418 & 1.0000\end{array}$

\section{Scatterplot Matrix}

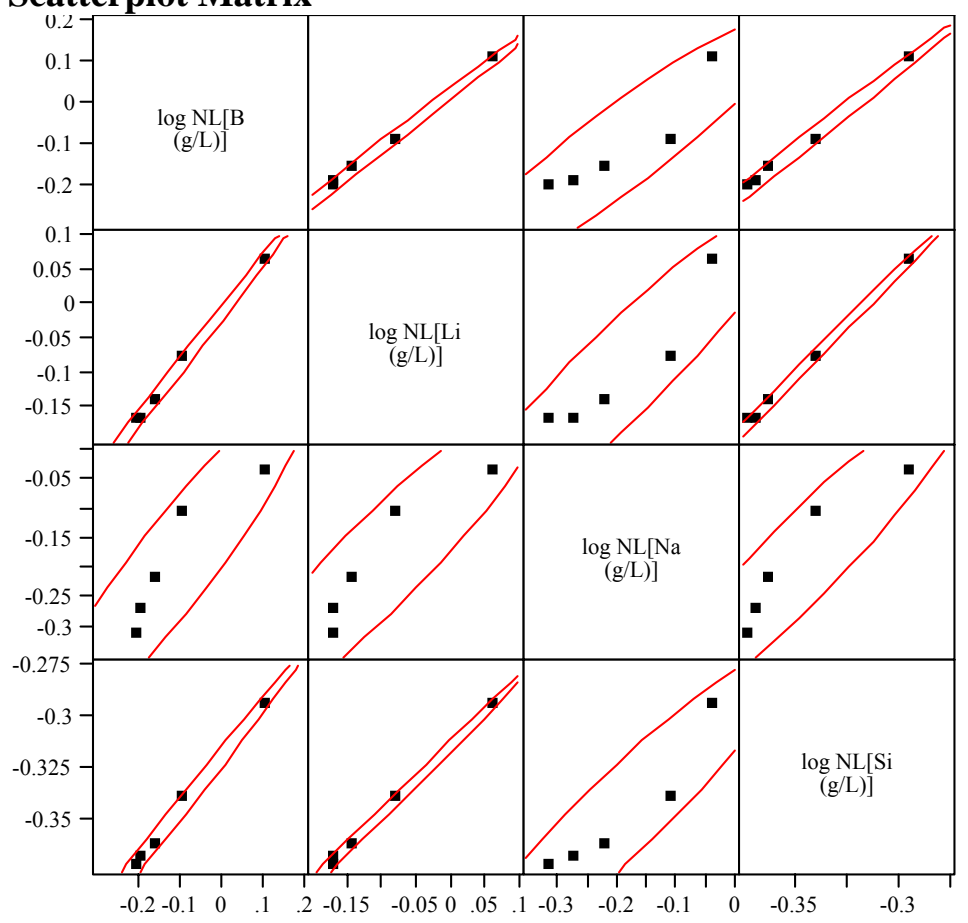

\section{Comp/HT=targeted-quenched}

\section{Multivariate}

\section{Correlations}

$\begin{array}{lrrrr} & \log \mathrm{NL}[\mathrm{B}(\mathrm{g} / \mathrm{L})] & \log \mathrm{NL}[\mathrm{Li}(\mathrm{g} / \mathrm{L})] & \log \mathrm{NL}[\mathrm{Na}(\mathrm{g} / \mathrm{L})] & \log \mathrm{NL}[\mathrm{Si}(\mathrm{g} / \mathrm{L})] \\ \log \mathrm{NL}[\mathrm{B}(\mathrm{g} / \mathrm{L})] & 1.0000 & 0.9787 & 0.9908 & 0.9011 \\ \log \mathrm{NL}[\mathrm{Li}(\mathrm{g} / \mathrm{L})] & 0.9787 & 1.0000 & 0.9469 & 0.9620 \\ \log \mathrm{NL}[\mathrm{Na}(\mathrm{g} / \mathrm{L})] & 0.9908 & 0.9469 & 1.0000 & 0.8350 \\ \log \mathrm{NL}[\mathrm{Si}(\mathrm{g} / \mathrm{L})] & 0.9011 & 0.9620 & 0.8350 & 1.0000\end{array}$

\section{Scatterplot Matrix}

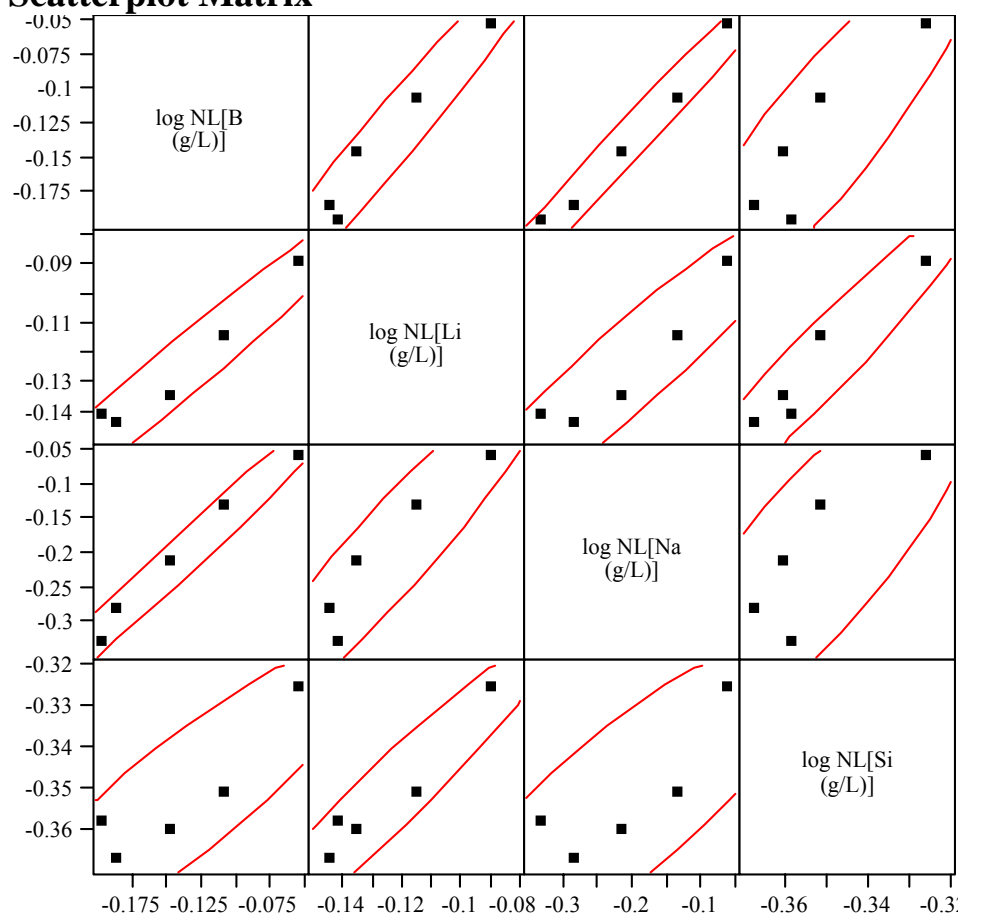




\section{Exhibit E7. Effects of Heat Treatment on PCT ppm-Response of Study Glasses}

\section{Glass \#=1}

Oneway Analysis of $\log [\mathrm{B}$ ppm] By Heat Treatment

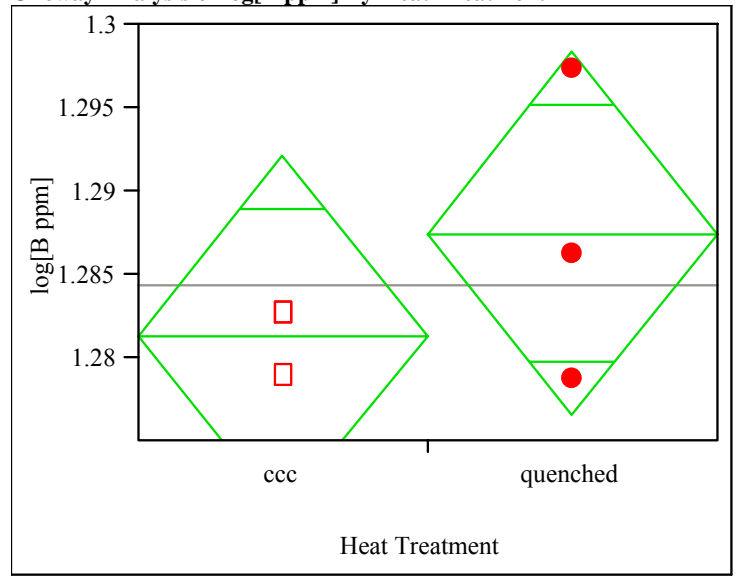

t Test

ccc-quenched

Assuming equal variances

Difference $\quad-0.00620$ t Ratio -1.11579

Std Err Dif 0.00556 DF 4

Upper CL Dif 0.00923 Prob $>|t| 0.3270$

Lower CL Dif -0.02164 Prob $>\mathrm{t} \quad 0.8365$

Confidence $\quad 0.95$ Prob $<\mathrm{t} \quad 0.1635$

Oneway Analysis of $\log [\mathrm{Li}$ ppm] By Heat Treatment

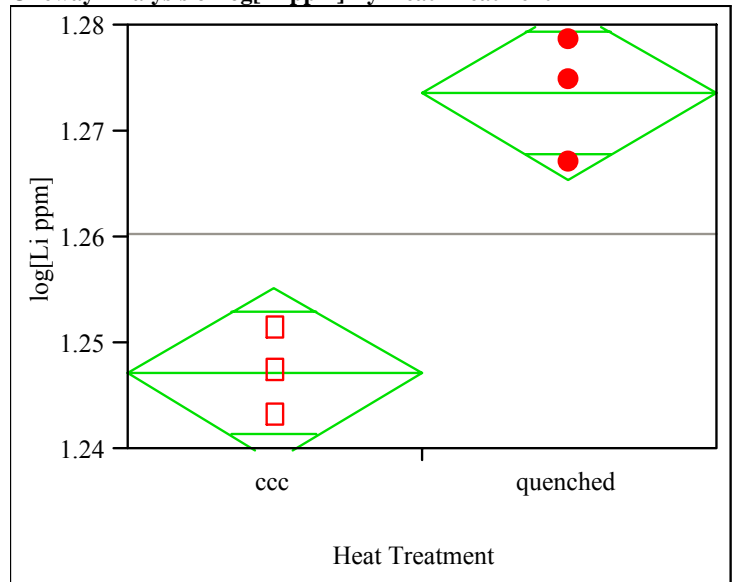

t Test

ccc-quenched

Assuming equal variances

Difference $\quad-0.02648$ t Ratio -6.38333

Std Err Dif $\quad 0.00415$ DF

Upper CL Dif -0.01496 Prob $>|t| \quad 0.0031$

Lower CL Dif -0.03799 Prob $>t \quad 0.9985$

Confidence $\quad 0.95$ Prob $<\mathrm{t} \quad 0.0015$

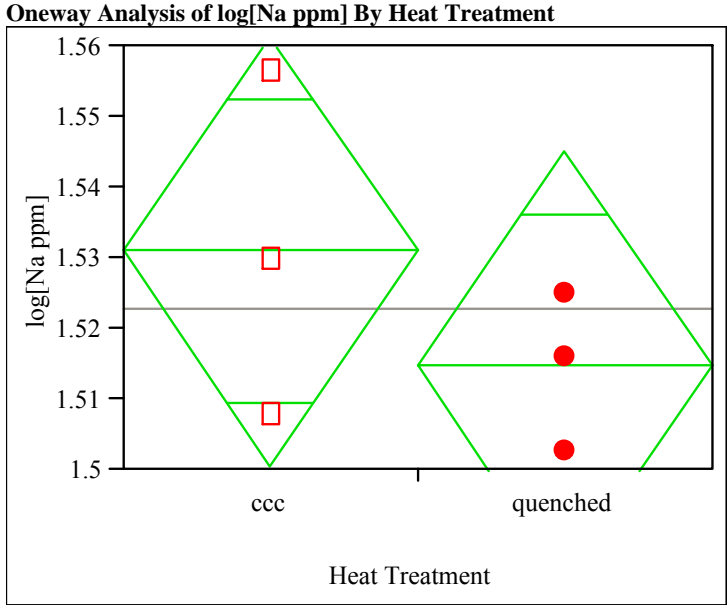

t Test

ccc-quenched

Assuming equal variances

$\begin{array}{lrlr}\text { Difference } & 0.01627 & \mathrm{t} \text { Ratio } & 1.047022 \\ \text { Std Err Dif } & 0.01554 & \text { DF } & 4 \\ \text { Upper CL Dif } & 0.05942 & \text { Prob }>|\mathrm{t}| & 0.3542 \\ \text { Lower CL Dif } & -0.02687 & \text { Prob }>\mathrm{t} & 0.1771 \\ \text { Confidence } & 0.95 & \text { Prob }<\mathrm{t} & 0.8229\end{array}$

Oneway Analysis of $\log [\mathrm{Si}$ ppm] By Heat Treatment

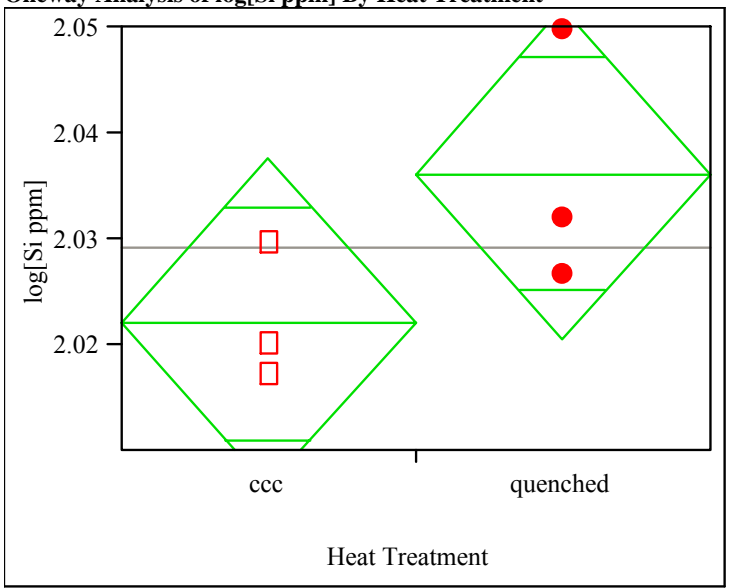

t Test

ccc-quenched

Assuming equal variances

Difference $\quad-0.01413$ t Ratio -1.77907

Std Err Dif $\quad 0.00794$ DF 4

Upper CL Dif 0.00792 Prob $>|\mathrm{t}| \quad 0.1498$

Lower CL Dif -0.03618 Prob $>t \quad 0.9251$

$\begin{array}{lrl}\text { Confidence } & 0.95 \text { Prob }<\mathrm{t} \quad 0.0749\end{array}$ 


\section{Exhibit E7. Effects of Heat Treatment on PCT ppm-Response of Study Glasses (continued)}

Glass \#=2

Oneway Analysis of $\log [\mathrm{B}$ ppm] By Heat Treatment

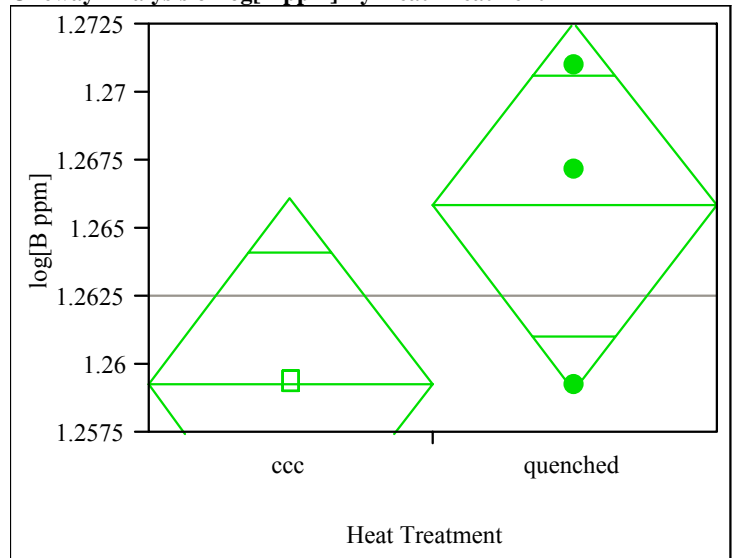

t Test

ccc-quenched

Assuming equal variances

Difference $\quad-0.00656$ t Ratio -1.892

Std Err Dif $\quad 0.00347$ DF

Upper CL Dif 0.00307 Prob $>|t| 0.1314$

Lower CL Dif -0.01619 Prob $>$ t 0.9343

Confidence $\quad 0.95$ Prob $<\mathrm{t} \quad 0.0657$

Oneway Analysis of $\log [\mathrm{Li}$ ppm] By Heat Treatment

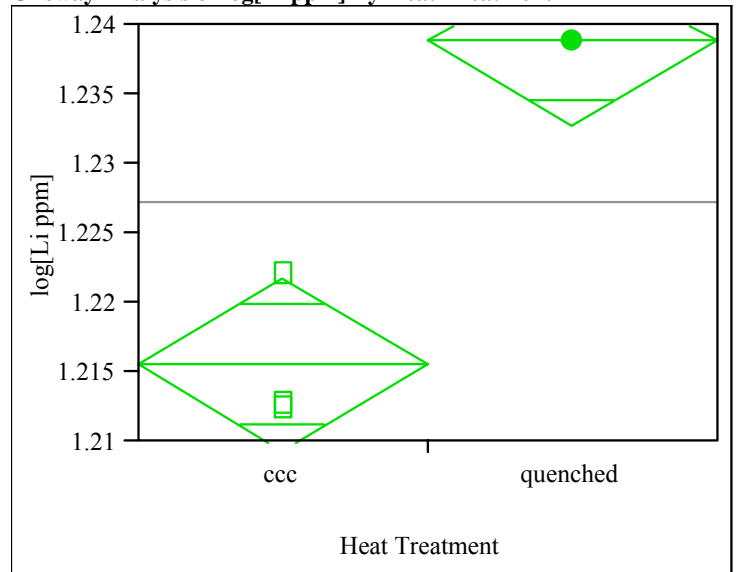

t Test

ccc-quenched

Assuming equal variances

$\begin{array}{lrlr}\text { Difference } & -0.02333 & \mathrm{t} \text { Ratio } & -7.40744 \\ \text { Std Err Dif } & 0.00315 & \text { DF } & 4 \\ \text { Upper CL Dif } & -0.01458 & \text { Prob }>|\mathrm{t}| & 0.0018 \\ \text { Lower CL Dif } & -0.03207 & \text { Prob }>\mathrm{t} & 0.9991 \\ \text { Confidence } & 0.95 & \text { Prob }<\mathrm{t} & 0.0009\end{array}$

Oneway Analysis of $\log [\mathrm{Na}$ ppm] By Heat Treatment

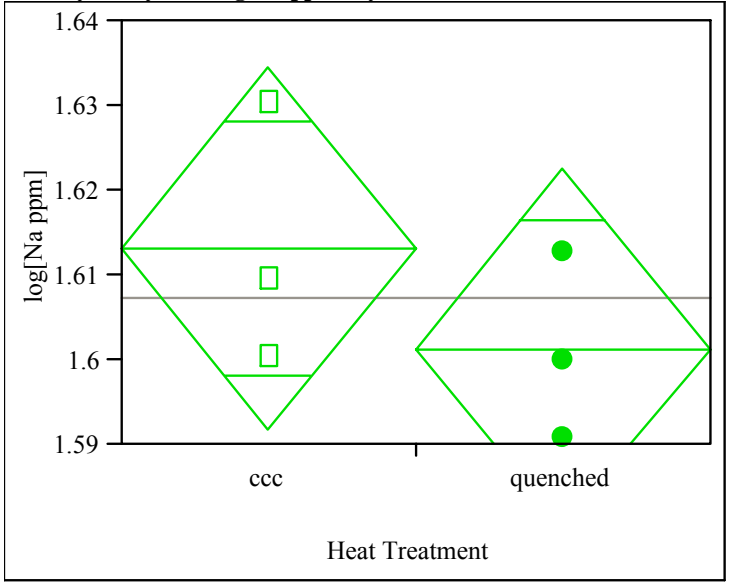

t Test

ccc-quenched

Assuming equal variances

$\begin{array}{lrlr}\text { Difference } & 0.01183 & \text { t Ratio } & 1.089891 \\ \text { Std Err Dif } & 0.01085 & \text { DF } & 4 \\ \text { Upper CL Dif } & 0.04195 & \text { Prob }>|t| & 0.3370 \\ \text { Lower CL Dif } & -0.01830 & \text { Prob }>\mathrm{t} & 0.1685 \\ \text { Confidence } & 0.95 & \text { Prob }<\mathrm{t} & 0.8315\end{array}$

Oneway Analysis of $\log [\mathrm{Si}$ ppm] By Heat Treatment

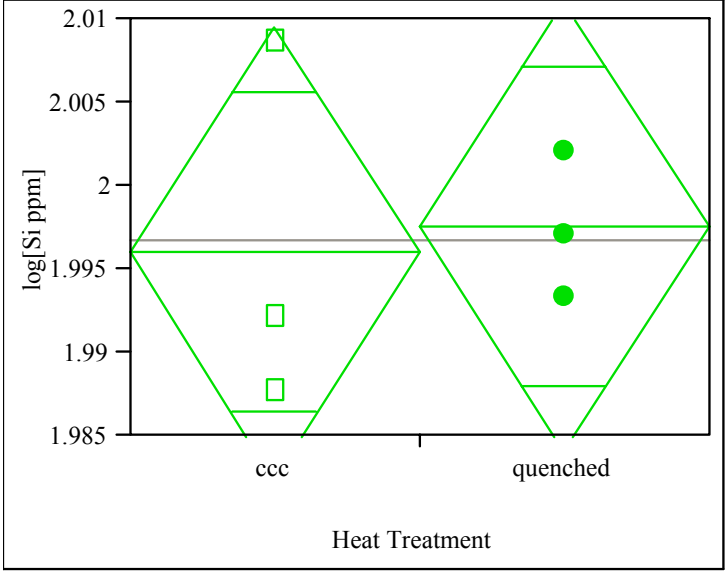

t Test

ccc-quenched

Assuming equal variances

$\begin{array}{lrlr}\text { Difference } & -0.00154 & \mathrm{t} \text { Ratio } & -0.22307 \\ \text { Std Err Dif } & 0.00690 & \text { DF } & 4 \\ \text { Upper CL Dif } & 0.01761 & \text { Prob }>|\mathrm{t}| & 0.8344 \\ \text { Lower CL Dif } & -0.02069 & \text { Prob }>\mathrm{t} & 0.5828 \\ \text { Confidence } & 0.95 & \text { Prob }<\mathrm{t} & 0.4172\end{array}$




\section{Exhibit E7. Effects of Heat Treatment on PCT ppm-Response of Study Glasses (continued)}

Glass \#=3

Oneway Analysis of $\log [\mathrm{B}$ ppm] By Heat Treatment

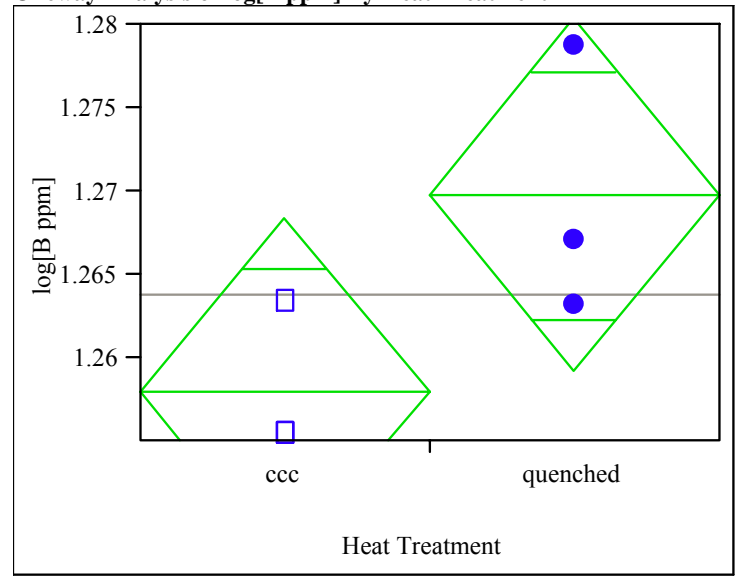

t Test

ccc-quenched

Assuming equal variances

Difference $\quad-0.01179$ t Ratio $\quad-2.20008$

Std Err Dif 0.00536 DF

Upper CL Dif 0.00309 Prob $>|t| \quad 0.0926$

Lower CL Dif -0.02668 Prob $>\mathrm{t} \quad 0.9537$

Confidence $\quad 0.95$ Prob $<\mathrm{t} \quad 0.0463$

Oneway Analysis of $\log [\mathrm{Li}$ ppm] By Heat Treatment

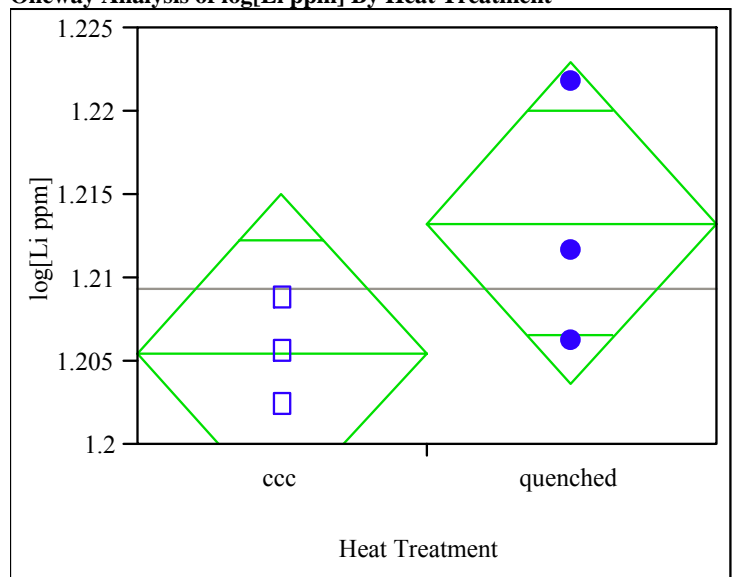

t Test

ccc-quenched

Assuming equal variances

Difference $\quad-0.00786$ t Ratio $\quad-1.60695$

Std Err Dif $\quad 0.00489$ DF

Upper CL Dif 0.00572 Prob $>|t| \quad 0.1833$

Lower CL Dif -0.02143 Prob $>$ t 0.9083

$\begin{array}{lrl}\text { Confidence } & 0.95 \text { Prob }<\mathrm{t} \quad 0.0917\end{array}$

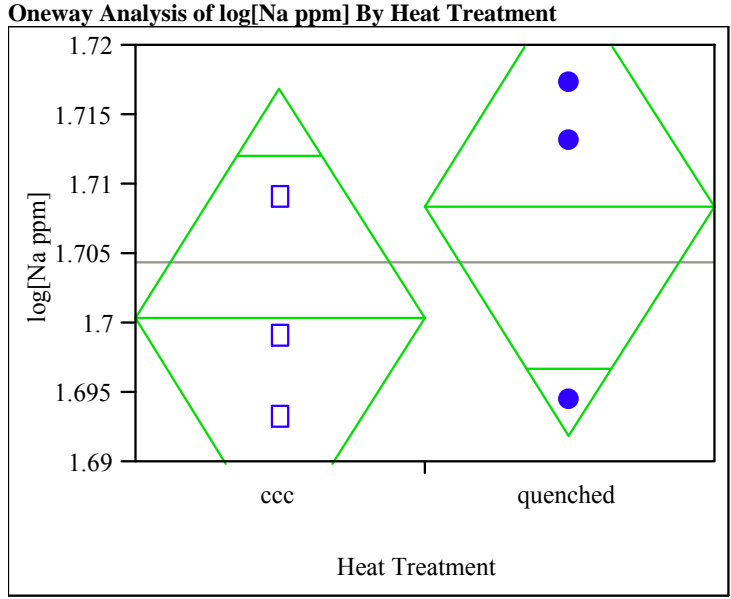

t Test

ccc-quenched

Assuming equal variances

Difference $\quad-0.00804$ t Ratio $\quad-0.95743$

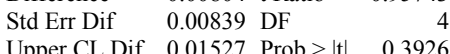

Upper CL Dif 0.01527 Prob $>|t| \quad 0.3926$

Lower CL Dif -0.03134 Prob $>t \quad 0.8037$

Confidence $\quad 0.95$ Prob $<\mathrm{t} \quad 0.1963$

Oneway Analysis of $\log [\mathrm{Si}$ ppm] By Heat Treatment

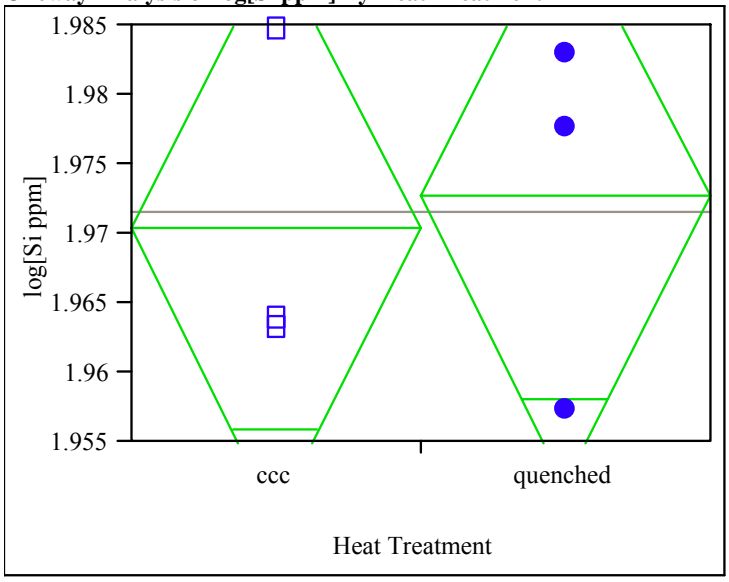

t Test

ccc-quenched

Assuming equal variances

Difference $\quad-0.00229$ t Ratio $\quad-0.21826$

Std Err Dif $\quad 0.01051$ DF

Upper CL Dif 0.02688 Prob $>|\mathrm{t}| \quad 0.8379$

Lower CL Dif -0.03147 Prob $>\mathrm{t} \quad 0.5810$

$\begin{array}{lll}\text { Confidence } & 0.95 \text { Prob }<\mathrm{t} \quad 0.4190\end{array}$ 
WSRC-STI-2006-00009

Revision 0

\section{Exhibit E7. Effects of Heat Treatment on PCT ppm-Response of Study Glasses (continued)}

Glass \#=4

Oneway Analysis of $\log [\mathrm{B}$ ppm] By Heat Treatment

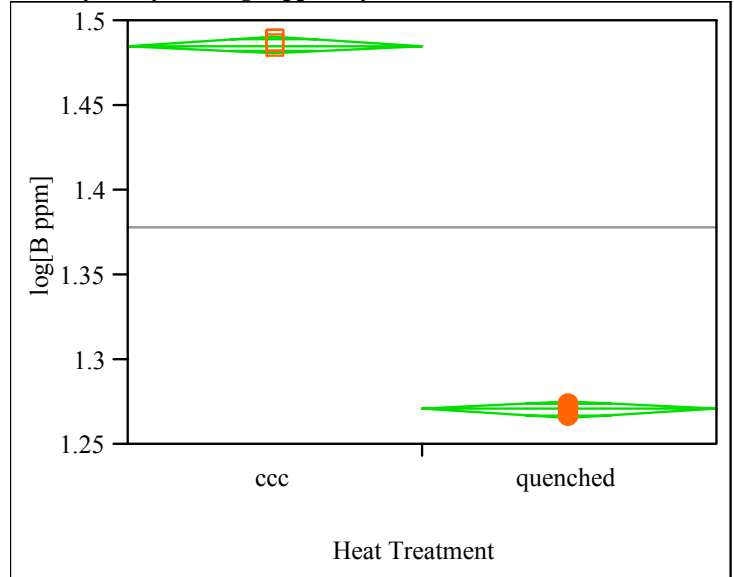

t Test

ccc-quenched

Assuming equal variances

Difference $\quad 0.214822$ t Ratio 90.49923

Std Err Dif $\quad 0.002374$ DF

Upper CL Dif 0.221413 Prob $>|t|<.0001$

Lower CL Dif 0.208232 Prob $>t \quad<.0001$

Confidence $\quad 0.95$ Prob $<\mathrm{t} \quad 1.0000$

Oneway Analysis of $\log [\mathrm{Li}$ ppm] By Heat Treatment

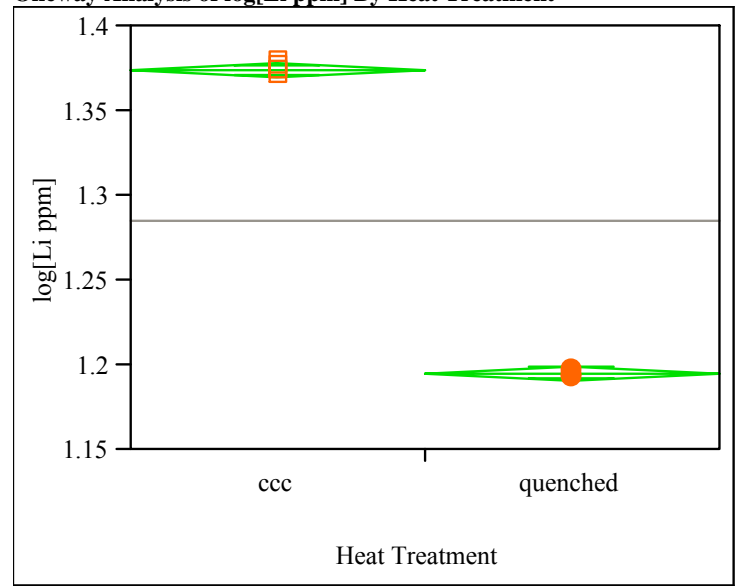

t Test

ccc-quenched

Assuming equal variances

Difference $\quad 0.178542$ t Ratio 81.15857

Std Err Dif 0.002200 DF 4

Upper CL Dif 0.184650 Prob $>|t|<.0001$

Lower CL Dif 0.172434 Prob $>\mathrm{t} \quad<.0001$

$\begin{array}{lll}\text { Confidence } & 0.95 \text { Prob }<\mathrm{t} \quad 1.0000\end{array}$

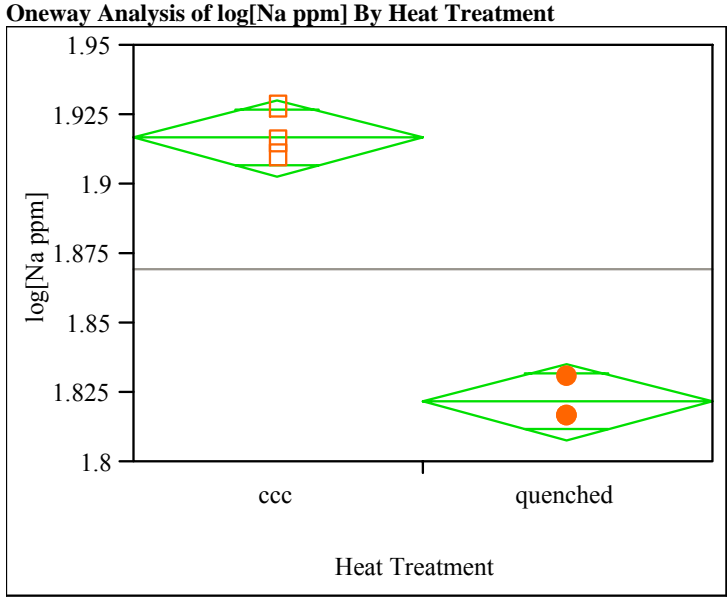

t Test

ccc-quenched

Assuming equal variances

Difference $\quad 0.094932$ t Ratio $\quad 13.5833$

$\begin{array}{lrlr}\text { Std Err Dif } & 0.006989 & \text { DF } & 4\end{array}$

Upper CL Dif 0.114337 Prob $>|t| \quad 0.0002$

Lower CL Dif 0.075528 Prob $>t<.0001$

Confidence $\quad 0.95$ Prob $<\mathrm{t} \quad 0.9999$

Oneway Analysis of $\log [\mathrm{Si}$ ppm] By Heat Treatment

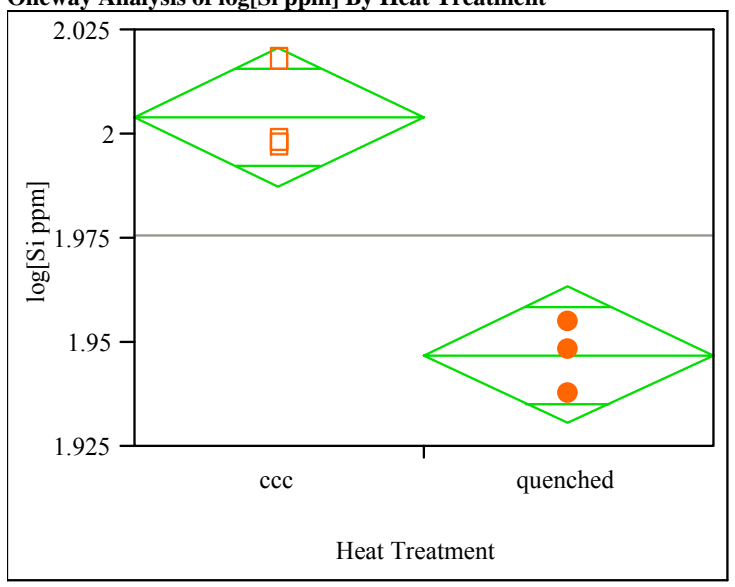

t Test

ccc-quenched

Assuming equal variances

Difference $\quad 0.057058$ t Ratio 6.77942

Std Err Dif $\quad 0.008416$ DF

Upper CL Dif 0.080425 Prob $>|t| 0.0025$

Lower CL Dif 0.033690 Prob $>$ t 0.0012

$\begin{array}{lll}\text { Confidence } & 0.95 \text { Prob }<\mathrm{t} \quad 0.9988\end{array}$ 


\section{Exhibit E7. Effects of Heat Treatment on PCT ppm-Response of Study Glasses (continued)}

Glass \#=5

Oneway Analysis of $\log [\mathrm{B}$ ppm] By Heat Treatment

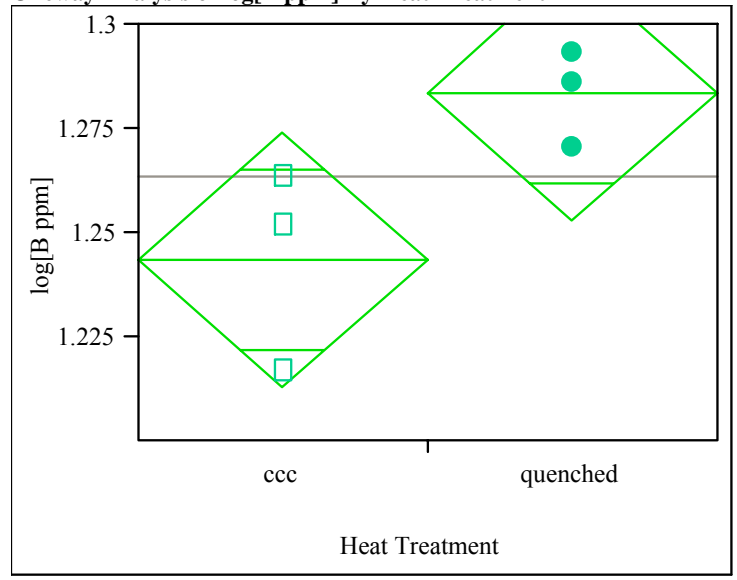

t Test

ccc-quenched

Assuming equal variances

Difference $\quad-0.04015$ t Ratio $\quad-2.57094$

Std Err Dif $\quad 0.01562$ DF

Upper CL Dif 0.00321 Prob $>|t| \quad 0.0619$

Lower CL Dif -0.08352 Prob $>t \quad 0.9690$

Confidence $\quad 0.95$ Prob $<\mathrm{t} \quad 0.0310$

Oneway Analysis of $\log [\mathrm{Li} \mathrm{ppm}]$ By Heat Treatment

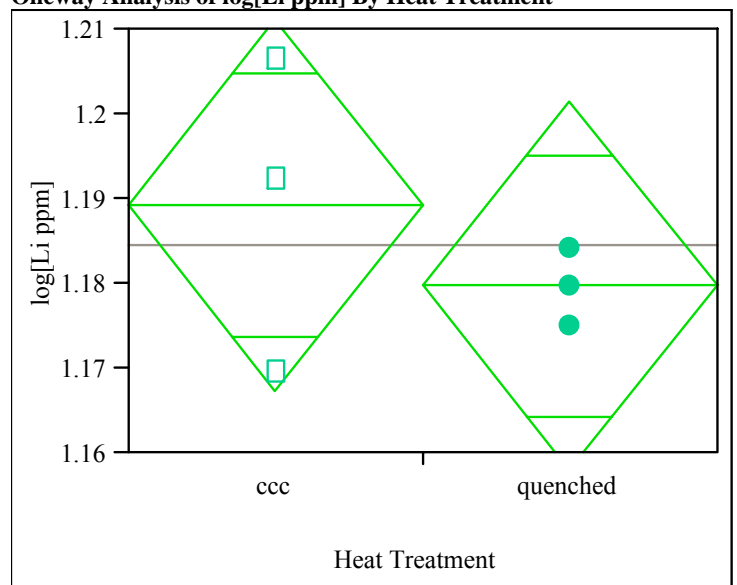

t Test

ccc-quenched

Assuming equal variances

$\begin{array}{lrlr}\text { Difference } & 0.00953 & \mathrm{t} \text { Ratio } & 0.856527 \\ \text { Std Err Dif } & 0.01112 & \text { DF } & 4 \\ \text { Upper CL Dif } & 0.04040 & \text { Prob }>|\mathrm{t}| & 0.4400 \\ \text { Lower CL Dif } & -0.02135 & \text { Prob }>\mathrm{t} & 0.2200 \\ \text { Confidence } & 0.95 & \text { Prob }<\mathrm{t} & 0.7800\end{array}$

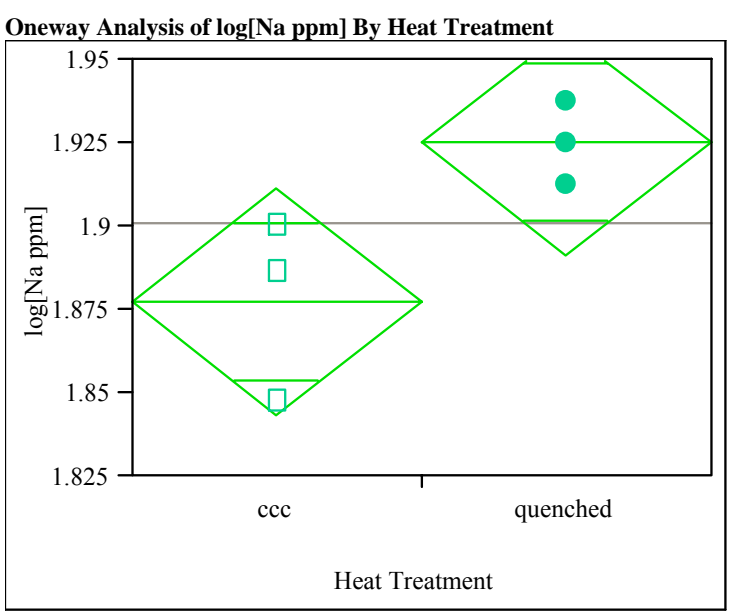

t Test

ccc-quenched

Assuming equal variances

Difference $\quad-0.04792$ t Ratio $\quad-2.78377$

$\begin{array}{lrlr}\text { Std Err Dif } & 0.01721 & \text { DF } & 4 \\ \text { Upper CL } & -0.00013 & \text { Prob }>|t| & 0.0496\end{array}$

Upper CL Dif -0.00013 Prob $>|t| \quad 0.0496$

$\begin{array}{lrll}\text { Lower CL Dif } & -0.09571 & \text { Prob }>t & 0.9752 \\ \text { Confidence } & 0.95 & \text { Prob }<\mathrm{t} & 0.0248\end{array}$

Oneway Analysis of $\log [\mathrm{Si}$ ppm] By Heat Treatment

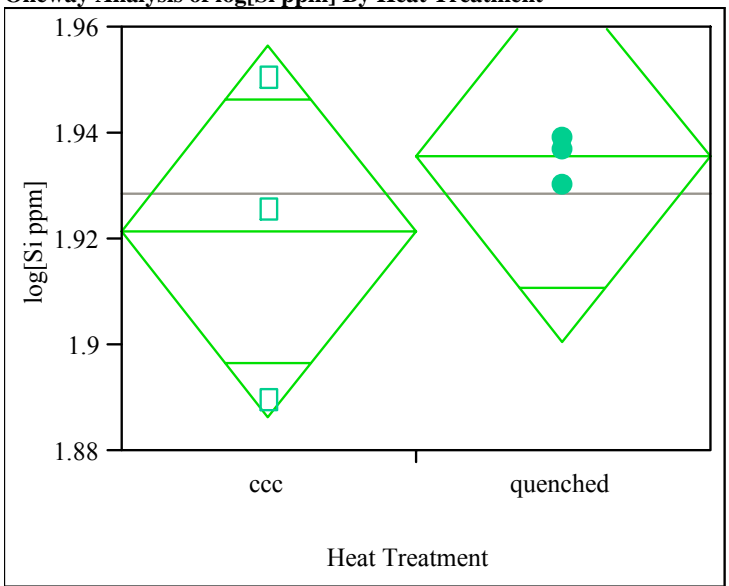

t Test

ccc-quenched

Assuming equal variances

Difference $\quad-0.01405$ t Ratio $\quad-0.7857$

$\begin{array}{lll}\text { Std Err Dif } \quad 0.01789 \text { DF } & 4\end{array}$

Upper CL Dif 0.03561 Prob $>|t| \quad 0.4760$

Lower CL Dif -0.06371 Prob $>t \quad 0.7620$

Confidence $\quad 0.95$ Prob $<\mathrm{t} \quad 0.2380$ 


\section{Exhibit E8. Effects of Heat Treatment for Study Glasses \\ by Compositional View}

\section{Composition=measured}

Variability Chart for log NL[B (g/L)]

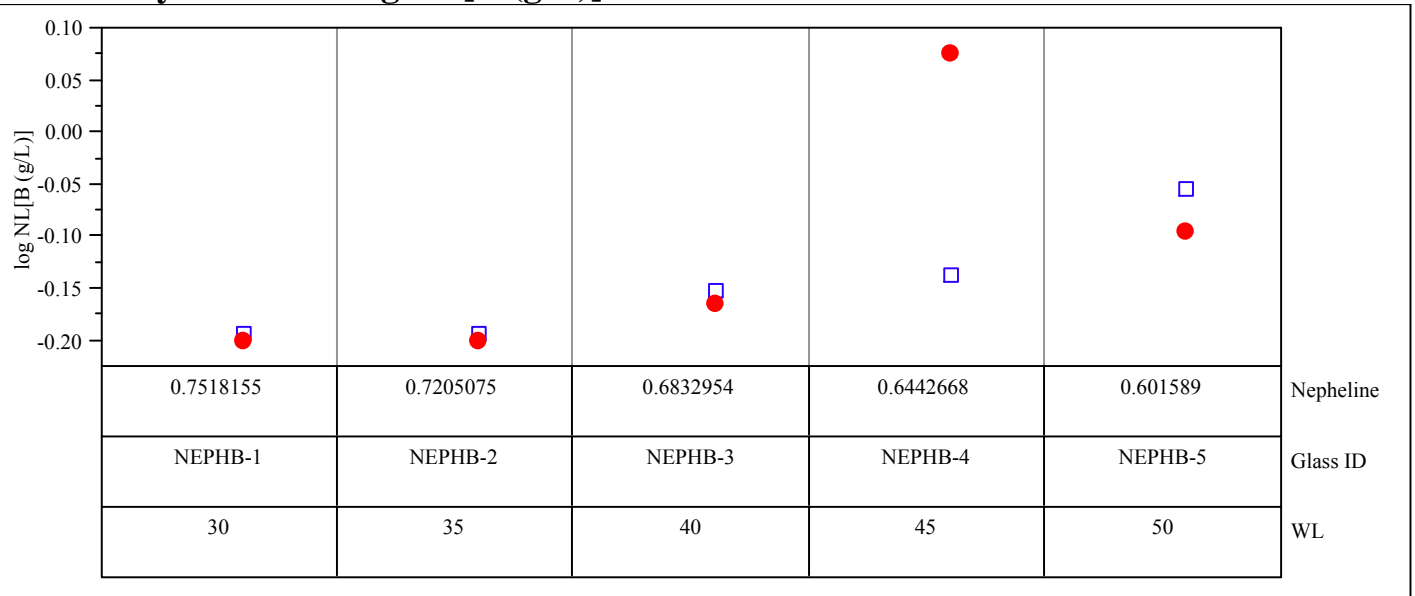

Variability Chart for log NL[Li (g/L)]

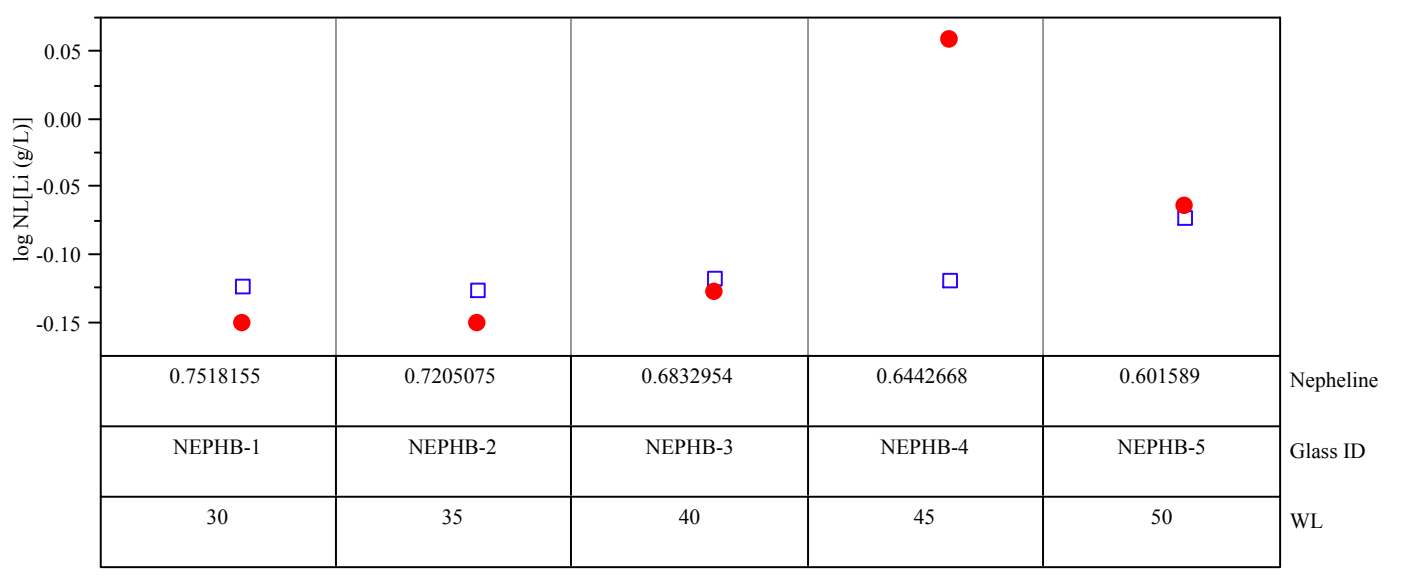

Variability Chart for log NL[Na (g/L)]

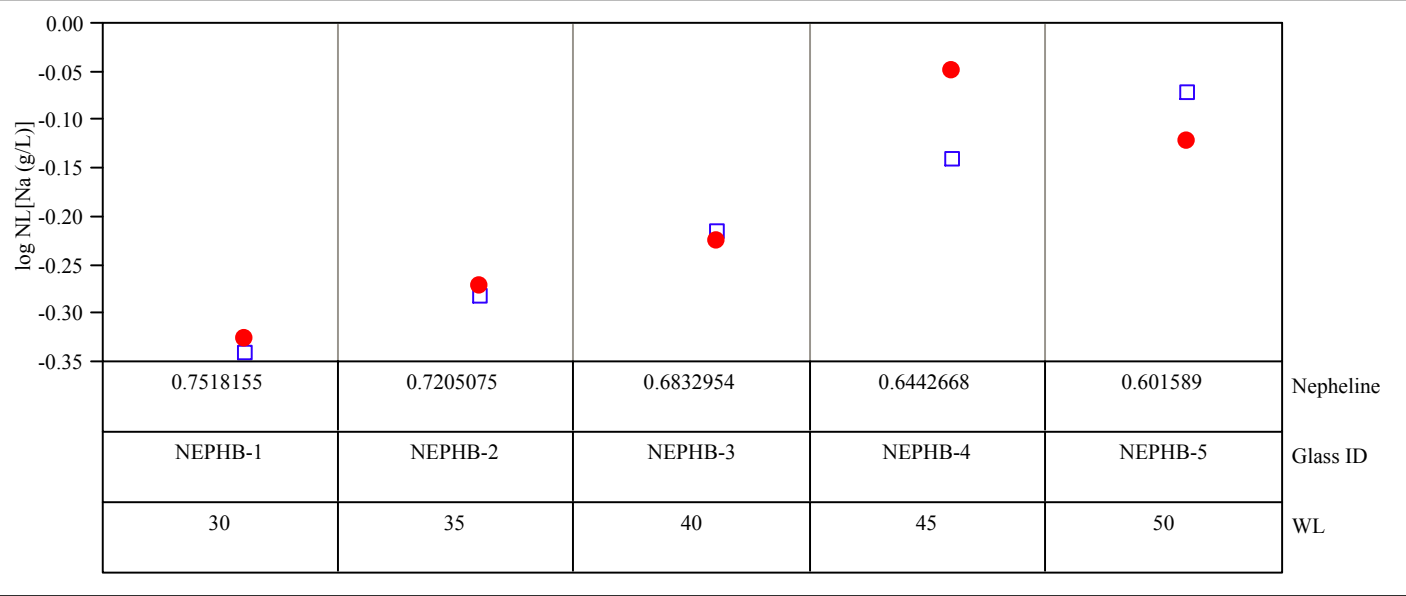




\section{Exhibit E8. Effects of Heat Treatment for Study Glasses by Compositional View (continued)}

Variability Chart for log NL[Si (g/L)]

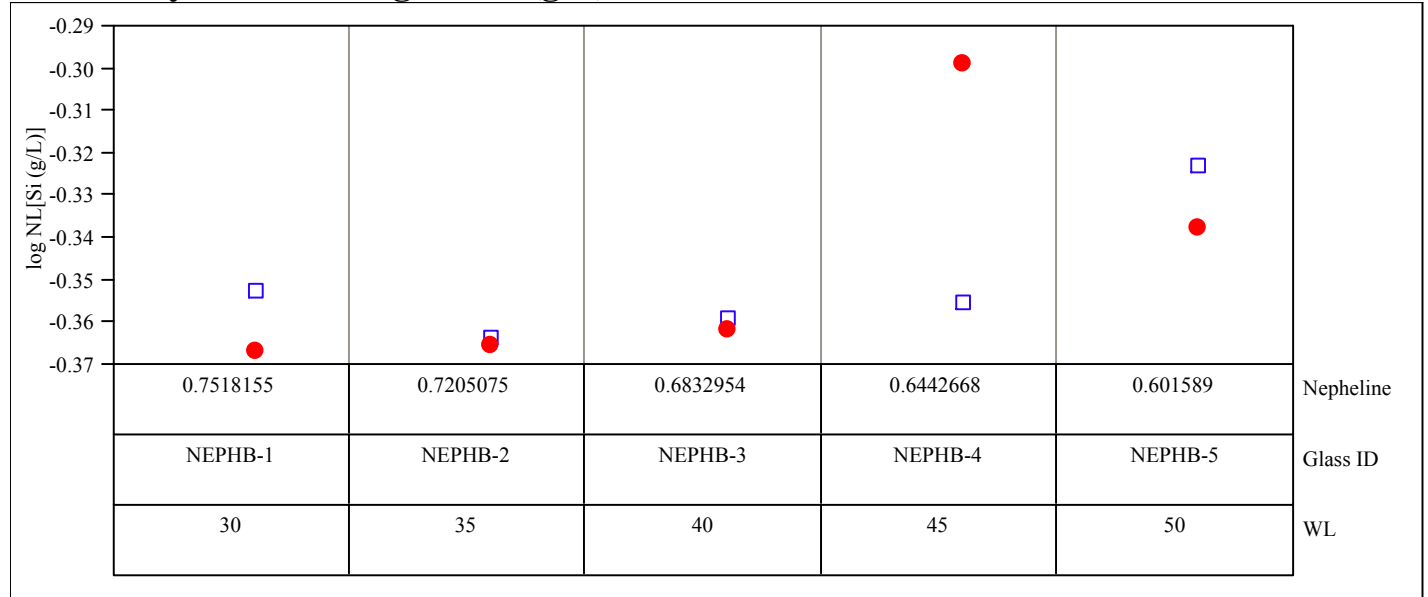

\section{Composition $=$ measured bc}

Variability Chart for $\log$ NL[B (g/L)]

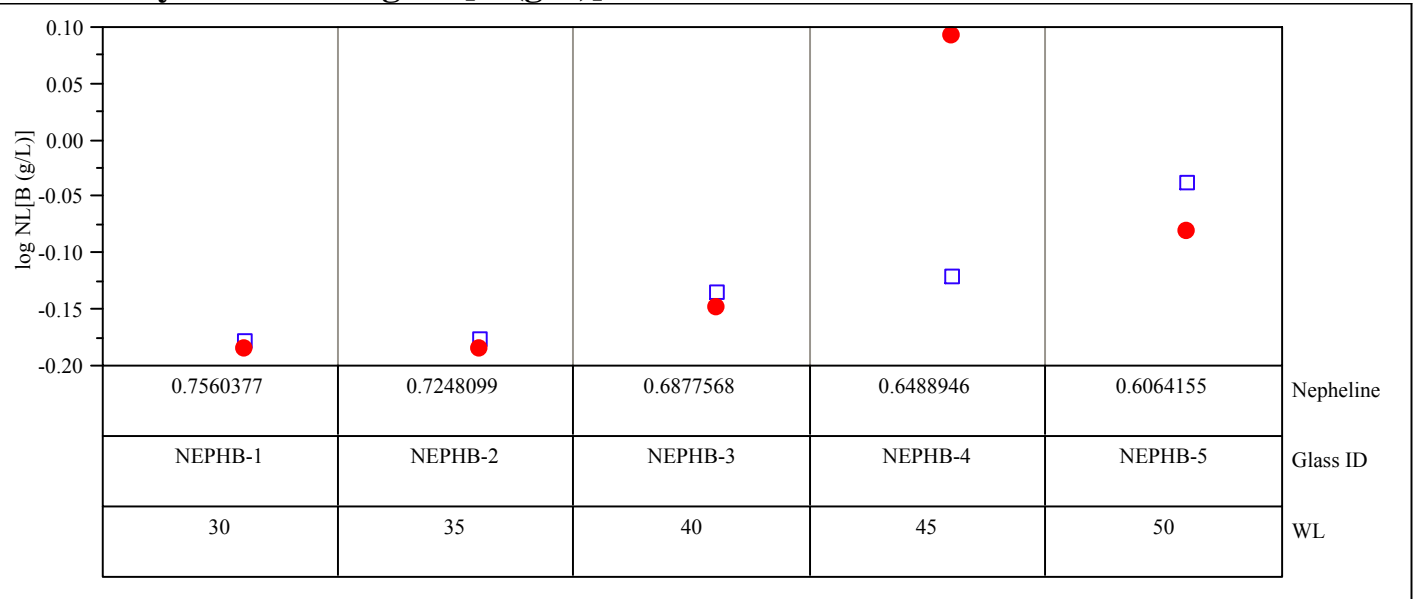

Variability Chart for log NL[Li (g/L)]

\begin{tabular}{|c|c|c|c|c|}
\hline & & & & \\
\hline & & & & \\
\hline \\
\hline 0.7560377 & 0.7248099 & 0.6877568 & 0.6488946 & 0.6064155 \\
\hline NEPHB-1 & NEPHB-2 & NEPHB-3 & NEPHB-4 & NEPHB-5 \\
\hline 30 & 35 & 40 & 45 & 50 \\
\hline
\end{tabular}




\section{Exhibit E8. Effects of Heat Treatment for Study Glasses by Compositional View (continued)}

Variability Chart for log NL[Na (g/L)]

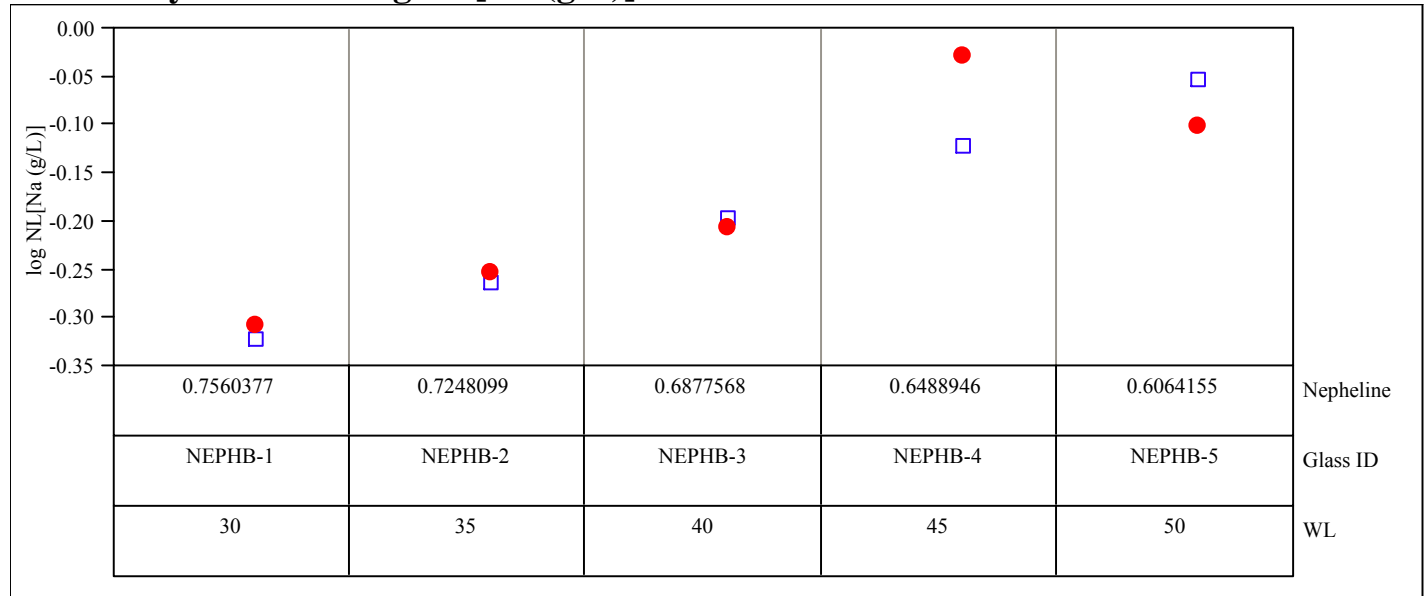

Variability Chart for log NL[Si (g/L)]

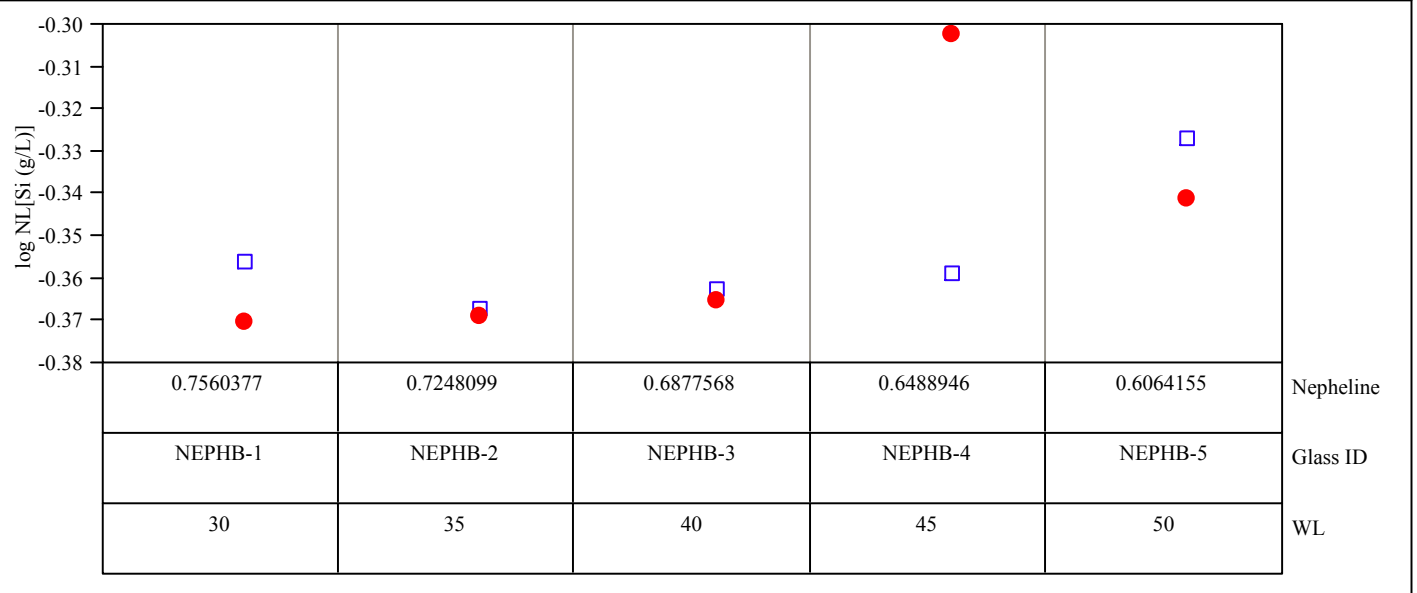

\section{Composition=targeted}

Variability Chart for $\log$ NL[B (g/L)]

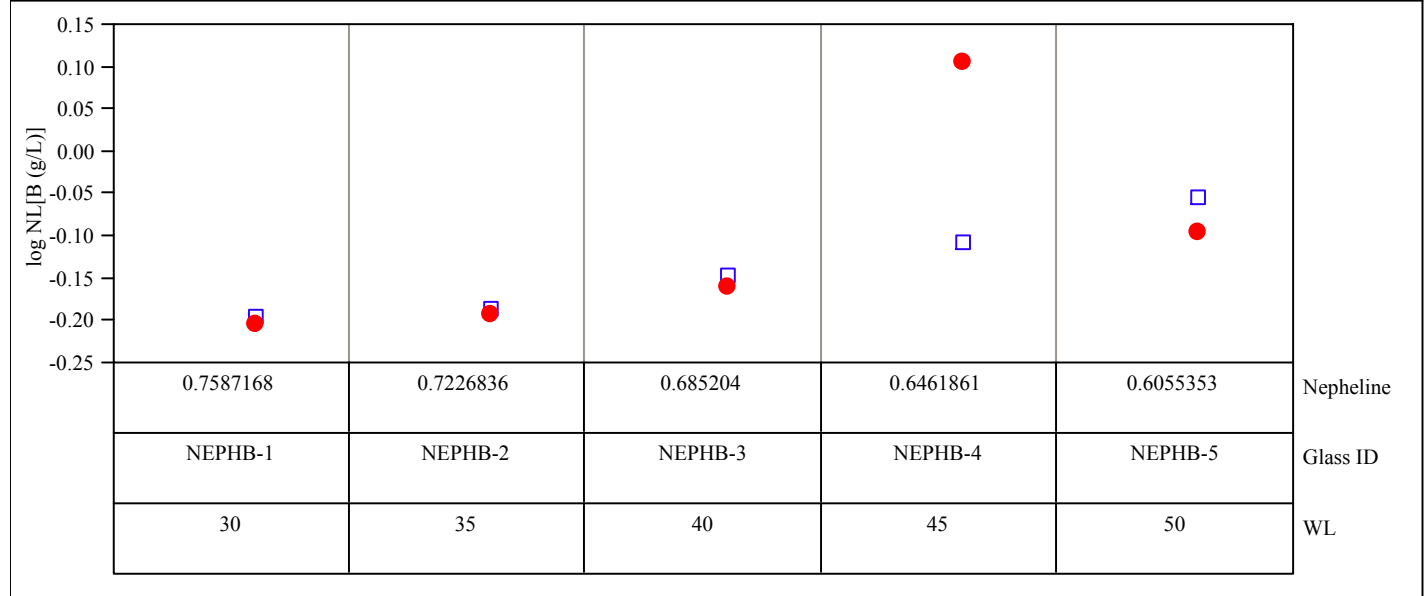




\section{Exhibit E8. Effects of Heat Treatment for Study Glasses by Compositional View (continued)}

Variability Chart for log NL[Li (g/L)]

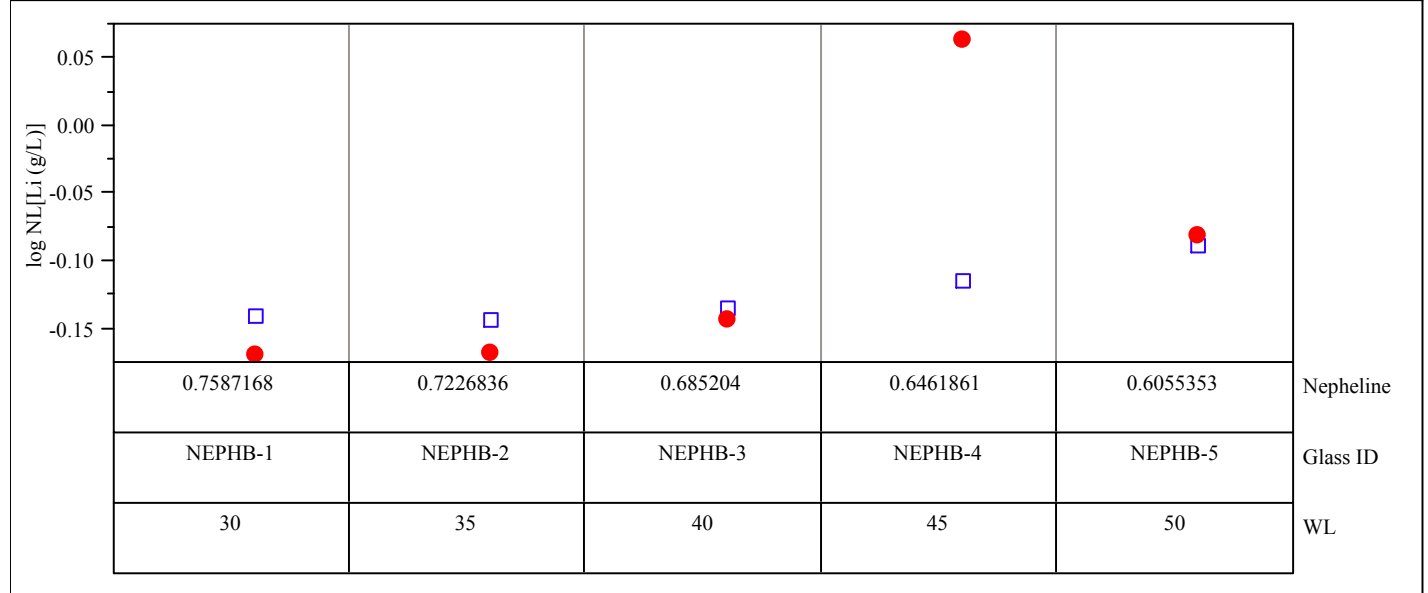

Variability Chart for log NL[Na (g/L)]

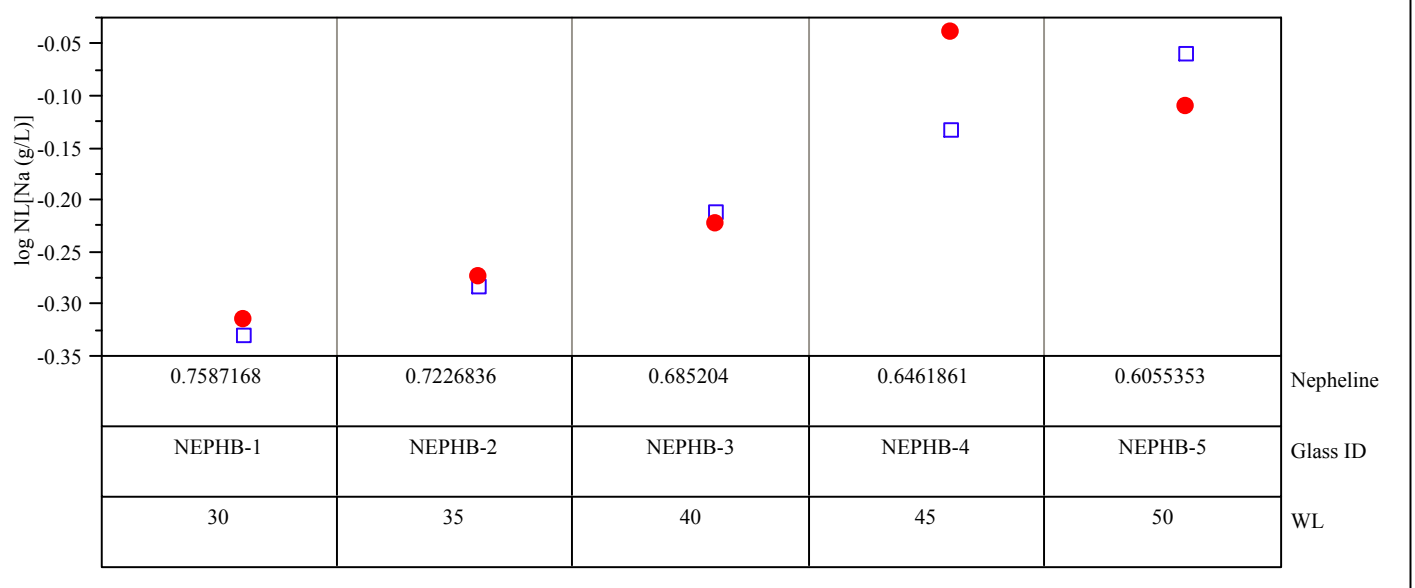

Variability Chart for log NL[Si (g/L)]

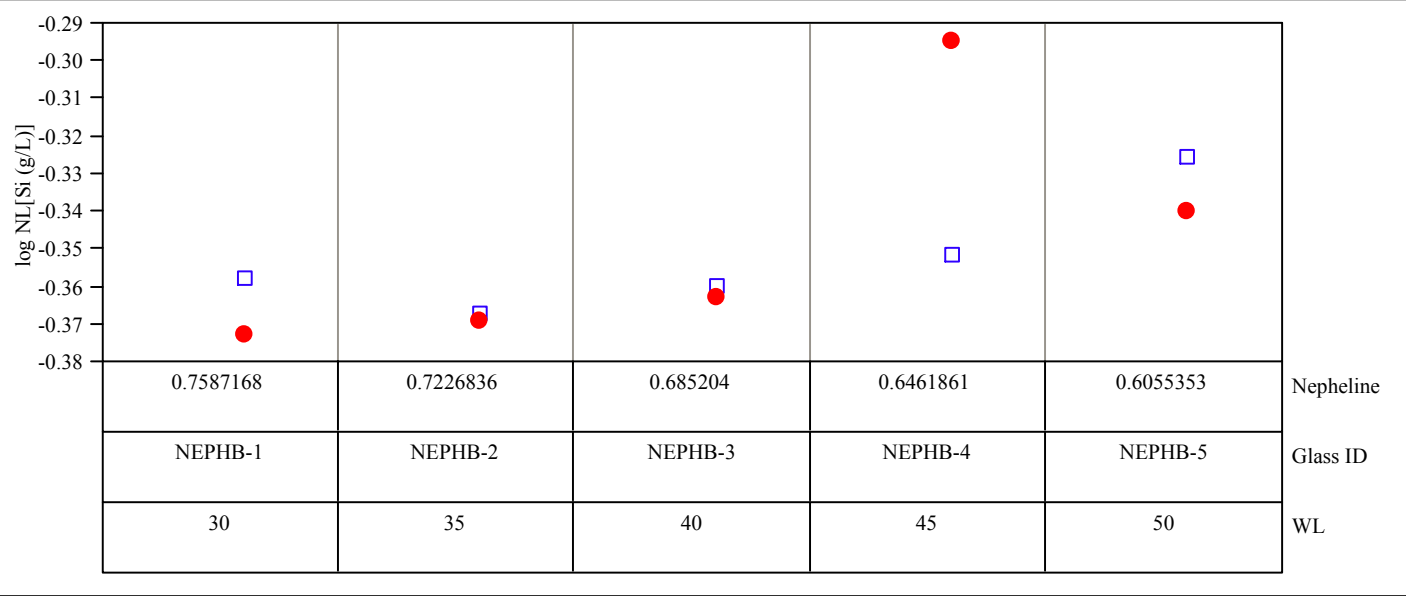


Exhibit E9. Effects of Heat Treatment for Study Glasses by Compositional View, Including Re-tested Values for ccc Glasses

\section{Comp View=measured}

Variability Chart for log NL[B (g/L)]

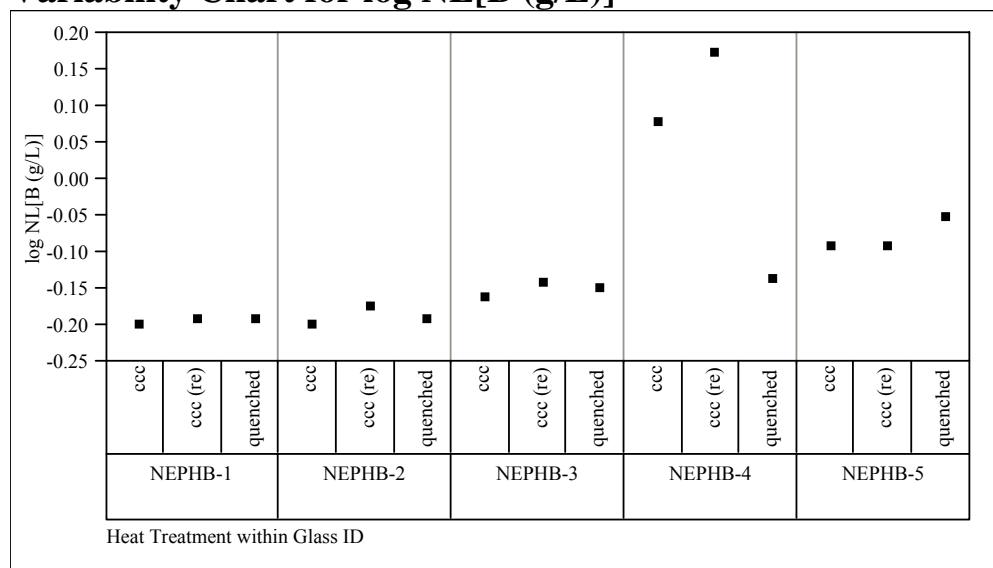

Variability Chart for $\log$ NL[Li(g/L)]

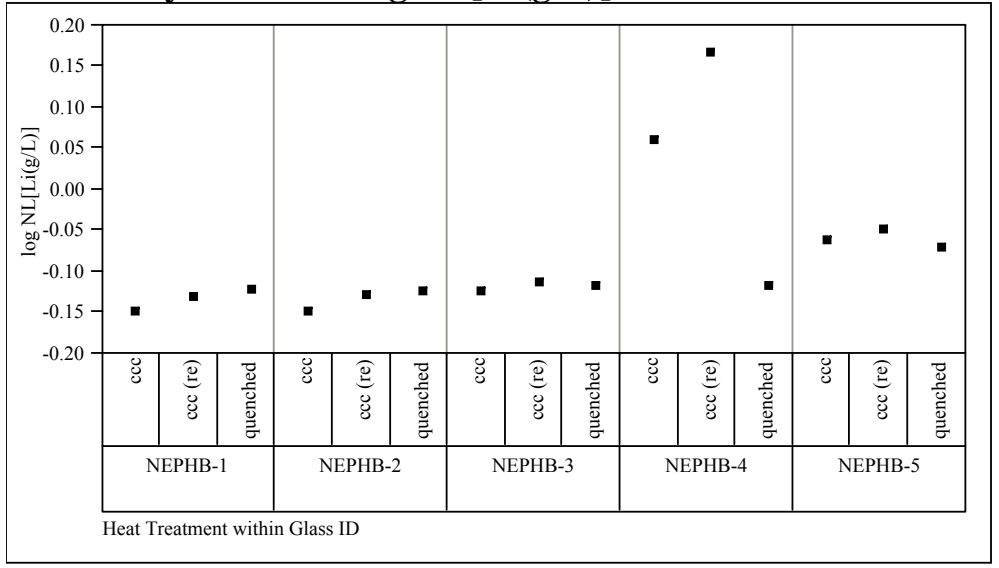

\section{Variability Chart for log NL[Na (g/L)]}
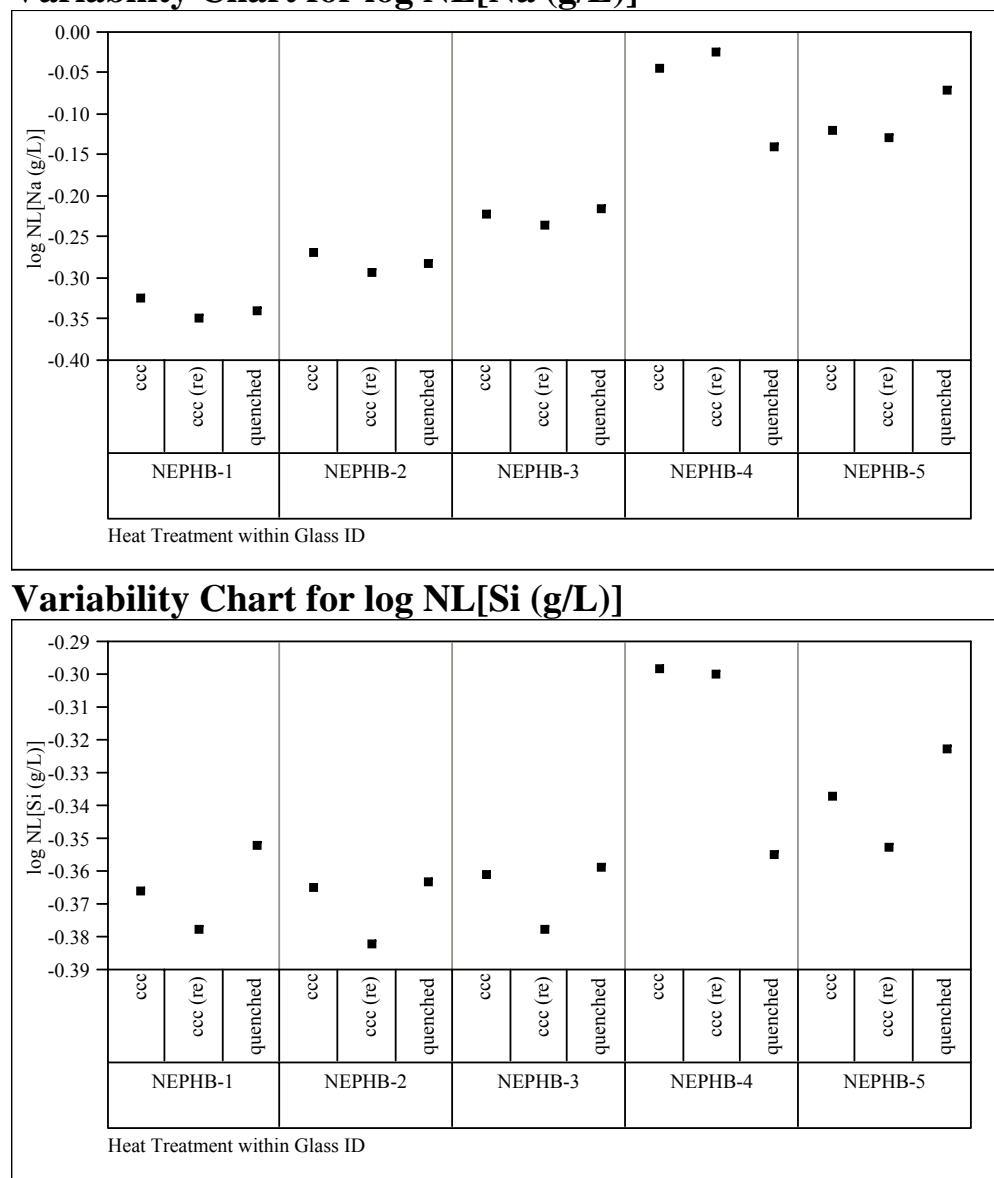


\section{Exhibit E9. Effects of Heat Treatment for Study Glasses by Compositional View, Including Re-tested Values for ccc Glasses (continued)}

Comp View=measured bc

Variability Chart for log NL[B (g/L)]

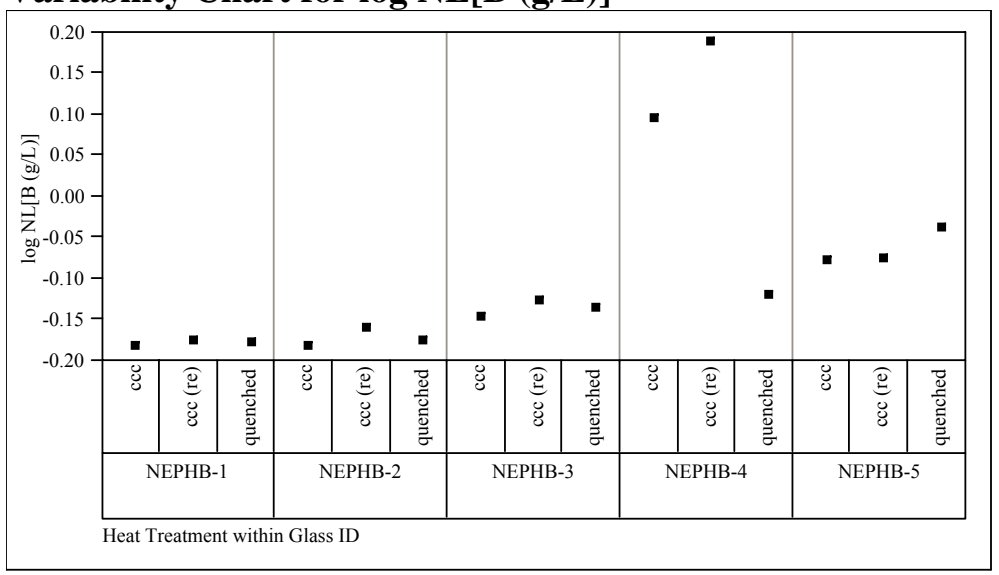

Variability Chart for log NL[Li(g/L)]

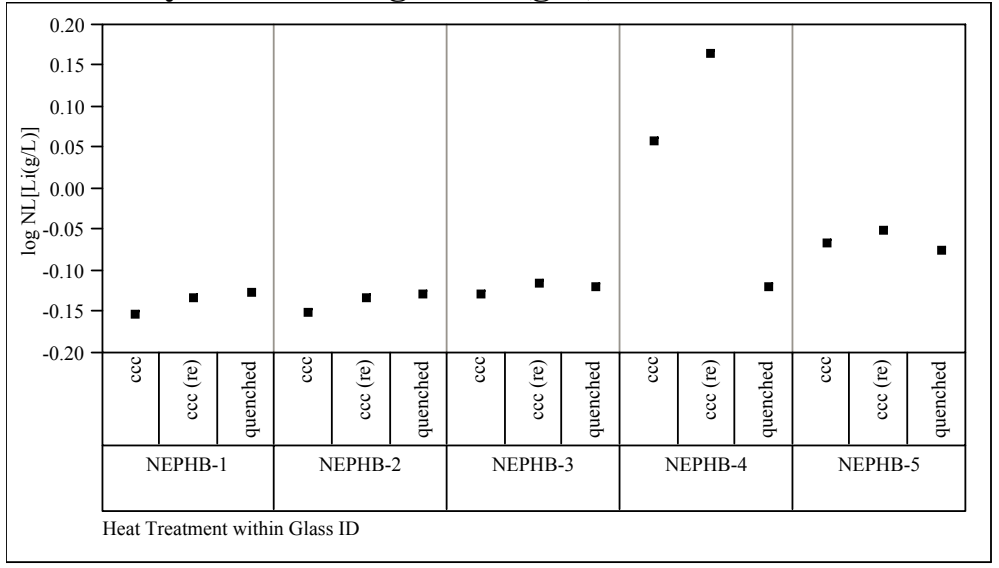

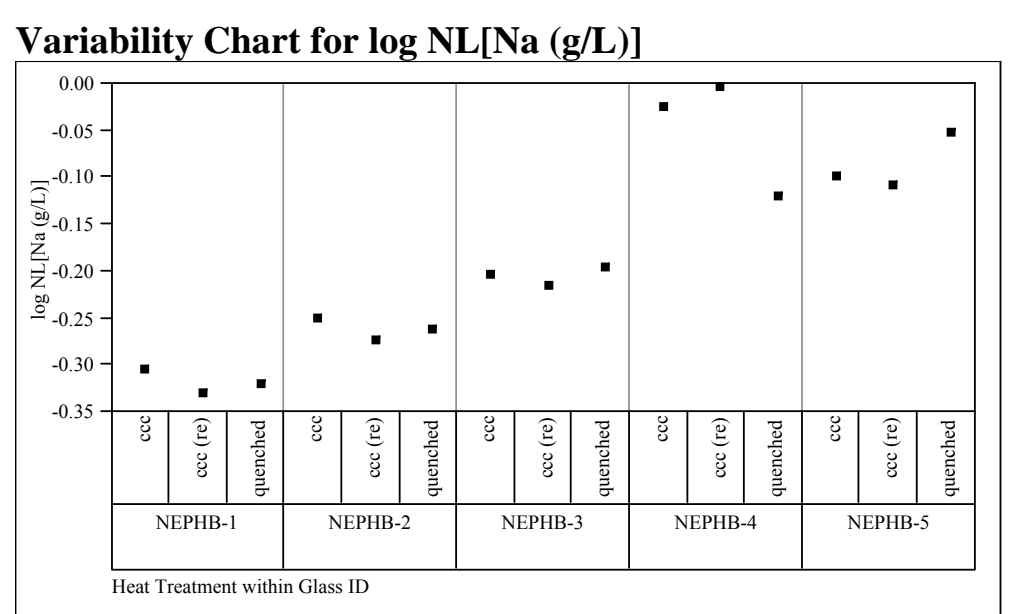

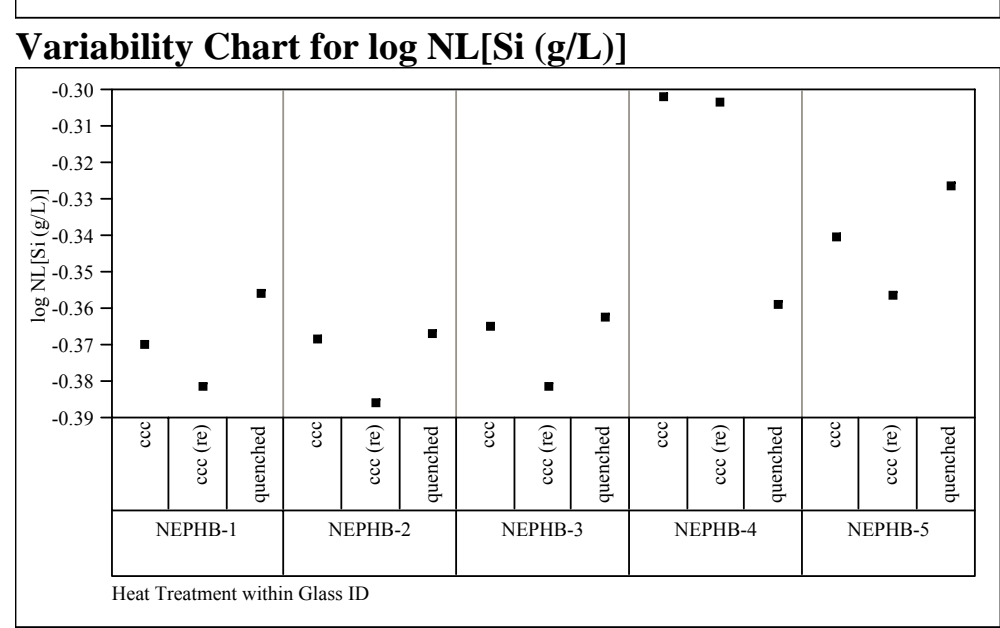


Exhibit E9. Effects of Heat Treatment for Study Glasses by Compositional View, Including Re-tested Values for ccc Glasses (continued)

\section{Comp View=targeted}

Variability Chart for $\log$ NL[B (g/L)]

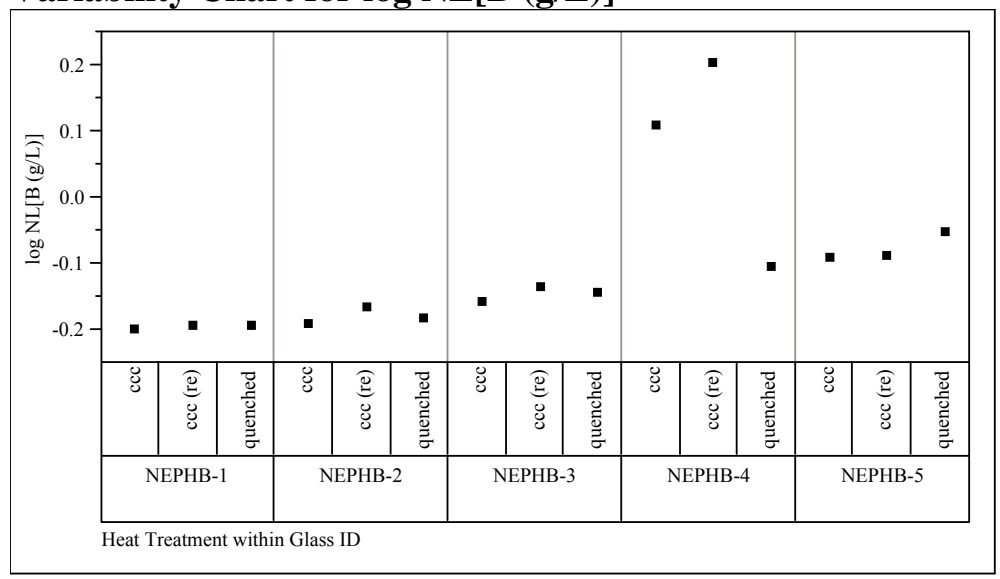

Variability Chart for log NL[Li(g/L)]

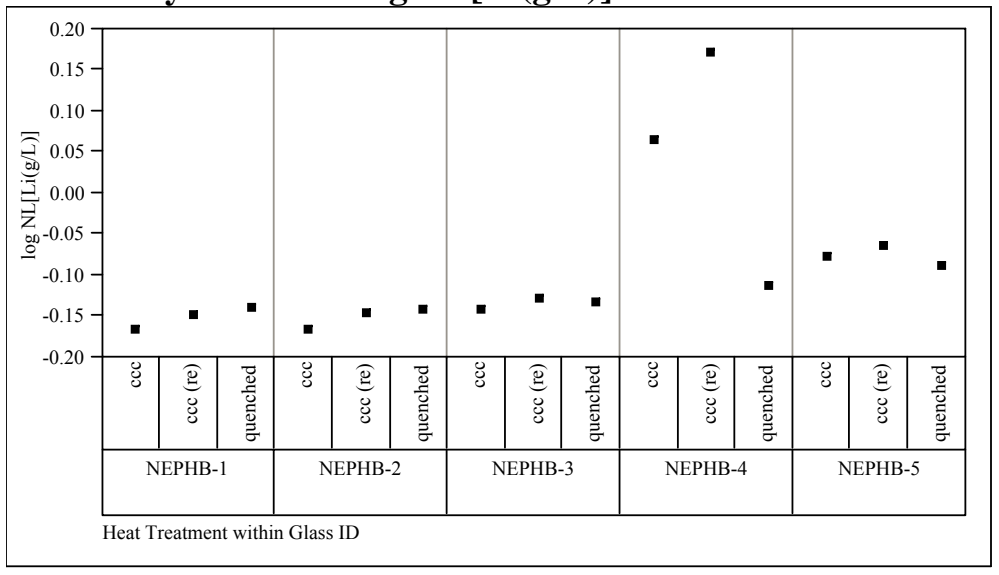

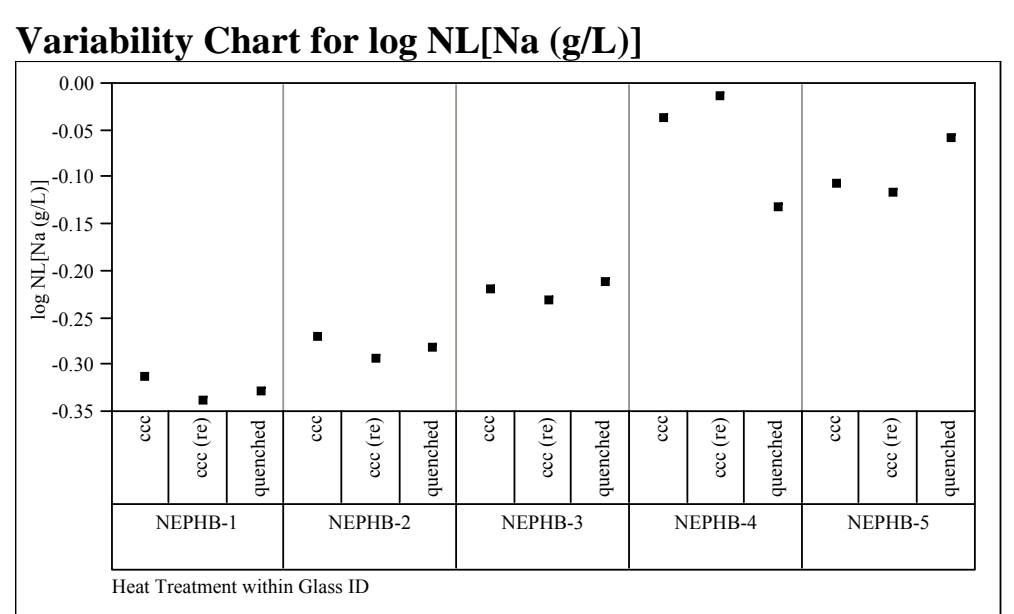

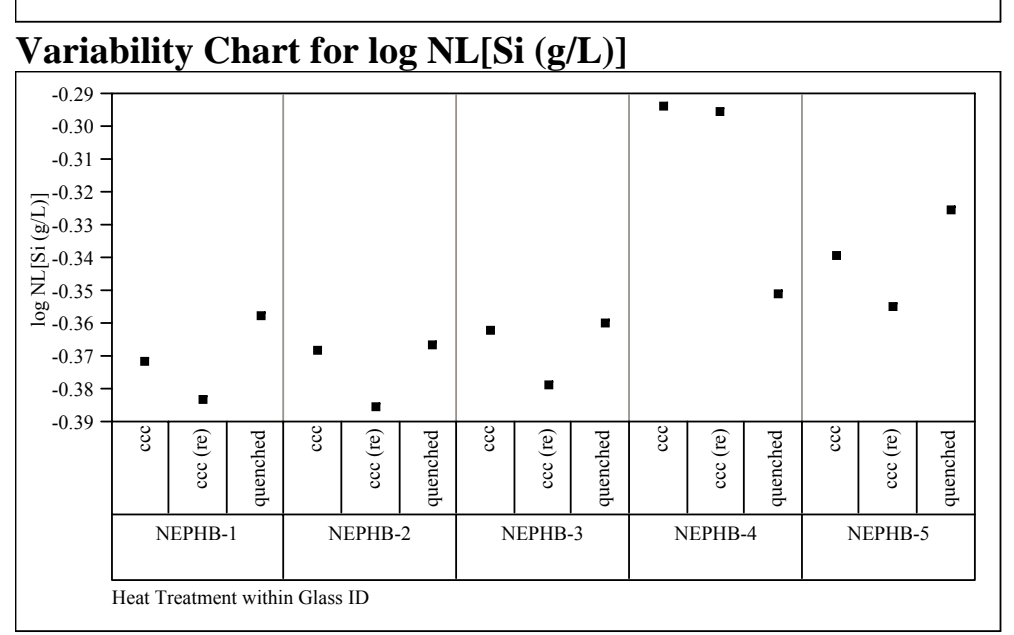




\section{Exhibit E10. $\Delta \mathrm{G}_{\mathrm{P}}$ Predictions versus Common Logarithm Normalized Leachate $(\log \mathrm{NL}[$.] $)$ for $\mathrm{B}, \mathrm{Li}, \mathrm{Na}$, and $\mathrm{Si}$ Over All Compositional Views and Heat Treatments}

Bivariate Fit of $\log N L[B(g / L)]$ By $\Delta G_{P}$

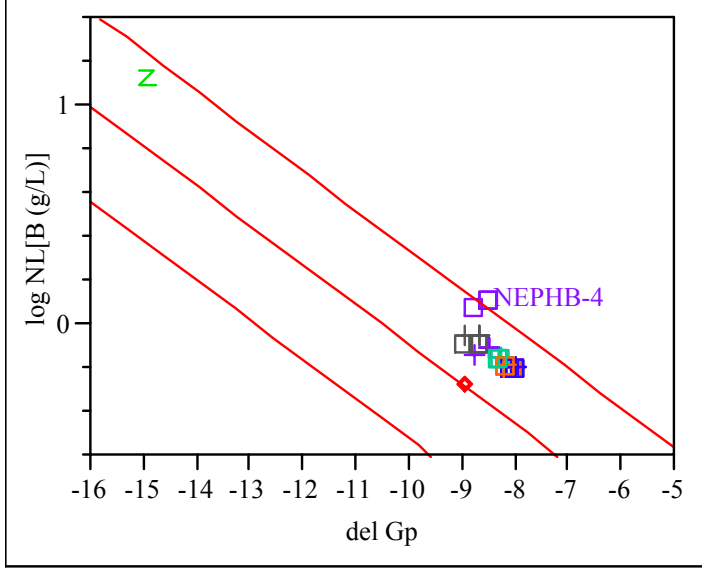

Linear Fit

Bivariate Fit of $\log N L[\mathrm{Li}(\mathrm{g} / \mathrm{L})]$ By $\Delta \mathrm{G}_{\mathrm{P}}$

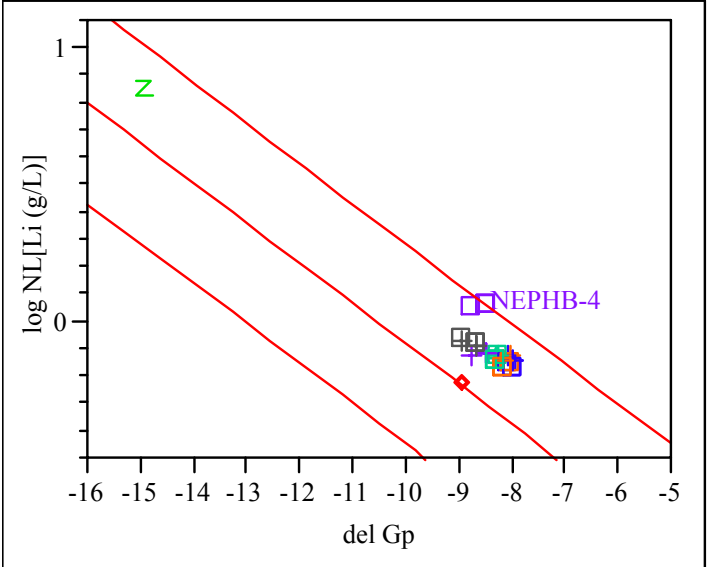

Linear Fit
Bivariate Fit of $\log \mathrm{NL}[\mathrm{Na}(\mathrm{g} / \mathrm{L})]$ By $\Delta \mathrm{G}_{\mathrm{P}}$

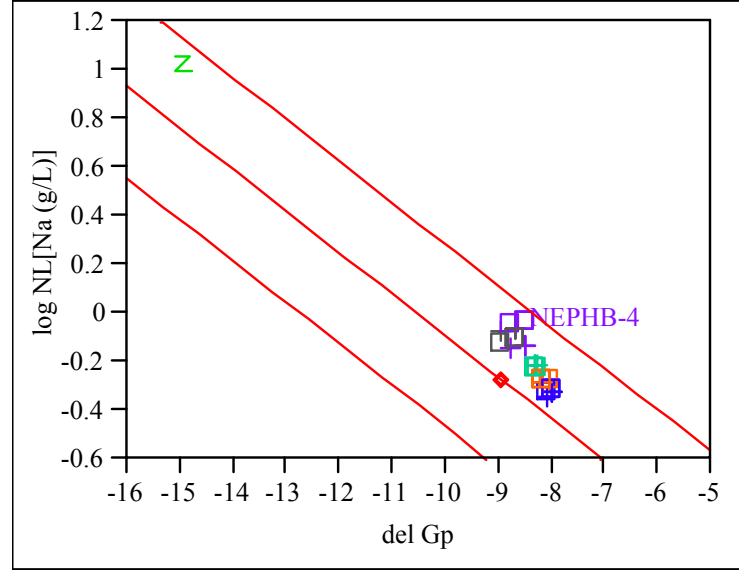

Linear Fit

Bivariate Fit of $\log \mathrm{NL}[\mathrm{Si}(\mathrm{g} / \mathrm{L})]$ By $\Delta \mathrm{G}_{\mathrm{P}}$

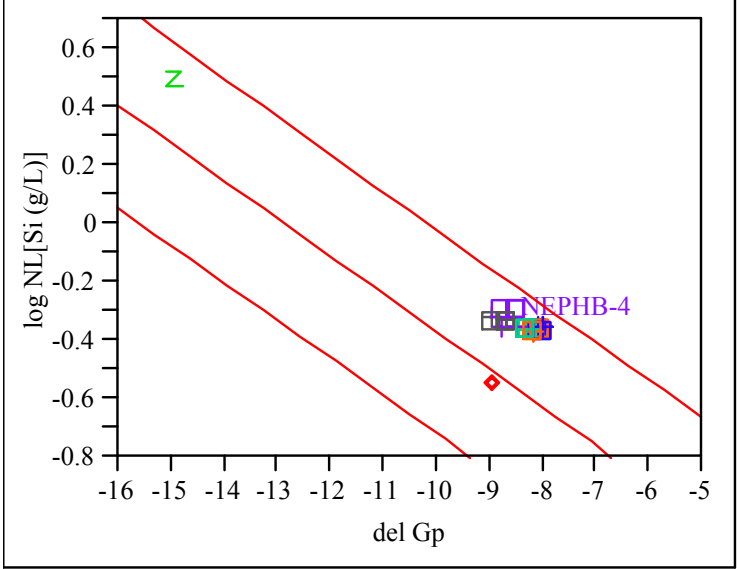

Linear Fit 


\section{Exhibit E11. $\Delta \mathrm{G}_{\mathrm{P}}$ Predictions versus Common Logarithm Normalized Leachate $(\log \mathrm{NL}[]$.$) for \mathrm{B}, \mathrm{Li}, \mathrm{Na}$, and $\mathrm{Si}$ Over All Compositional Views for Quenched Glasses}

Bivariate Fit of $\log N L[B(g / L)]$ By $\Delta G_{P}$

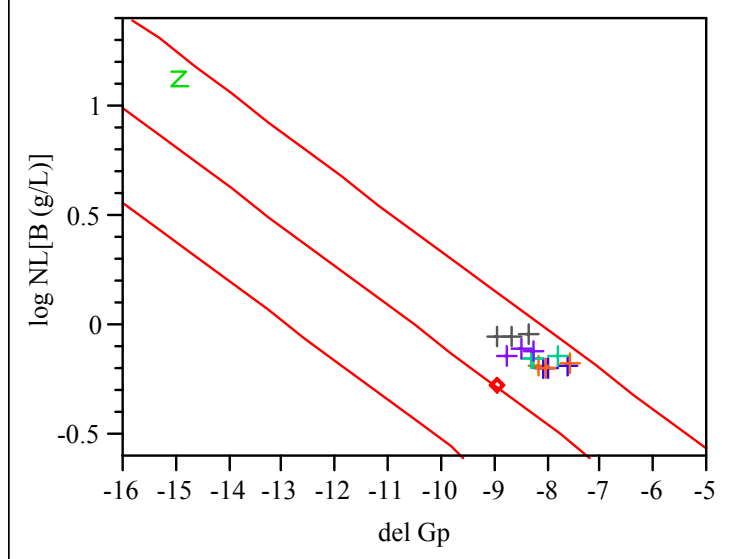

- Linear Fit

Bivariate Fit of $\log \mathrm{NL}[\mathrm{Li}(\mathrm{g} / \mathrm{L})]$ By $\Delta \mathrm{G}_{\mathrm{P}}$

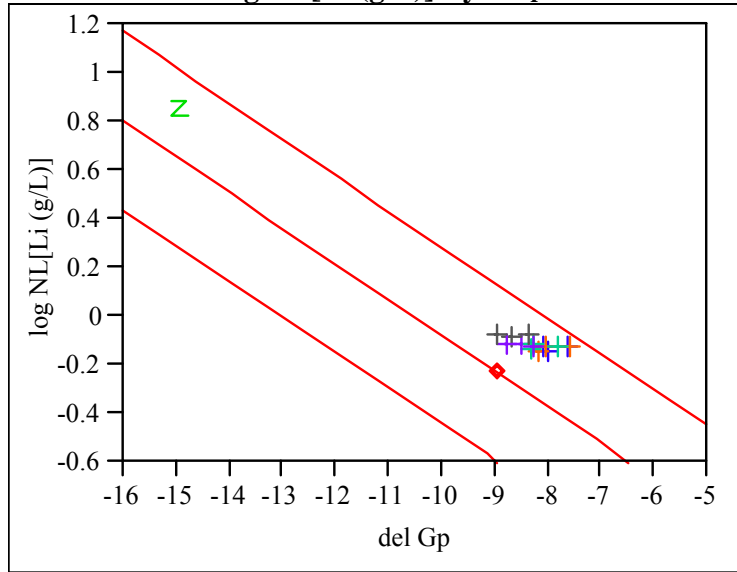

- Linear Fit
Bivariate Fit of $\log \mathrm{NL}[\mathrm{Na}(\mathrm{g} / \mathrm{L})]$ By $\Delta \mathrm{G}_{\mathrm{P}}$

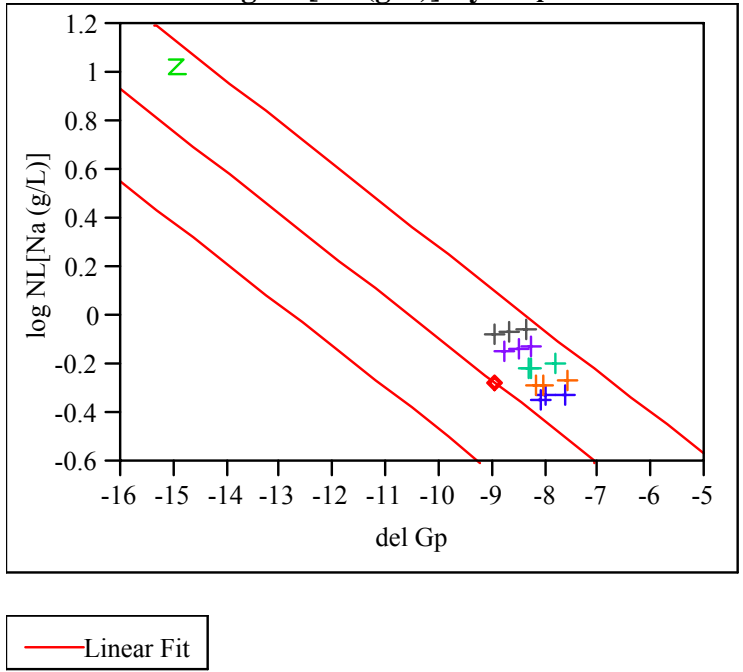

Bivariate Fit of $\log \mathrm{NL}[\mathrm{Si}(\mathrm{g} / \mathrm{L})]$ By $\Delta \mathrm{G}_{\mathrm{P}}$

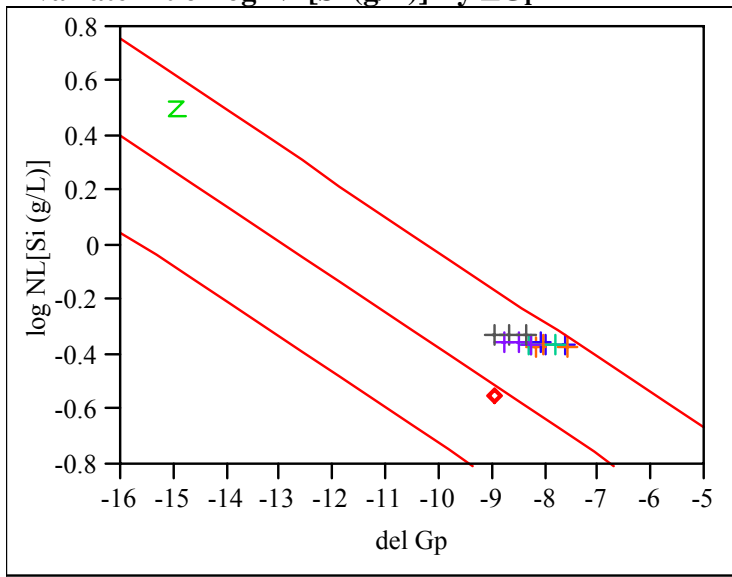

- Linear Fit 


\section{Exhibit E12. $\Delta \mathrm{G}_{\mathrm{P}}$ Predictions versus Common Logarithm Normalized Leachate (log NL[.]) for B, Li, Na, and Si Over All Compositional Views for ccc Glasses}

Bivariate Fit of $\log$ NL[B (g/L)]

By $\Delta \mathbf{G}_{\mathbf{P}}$

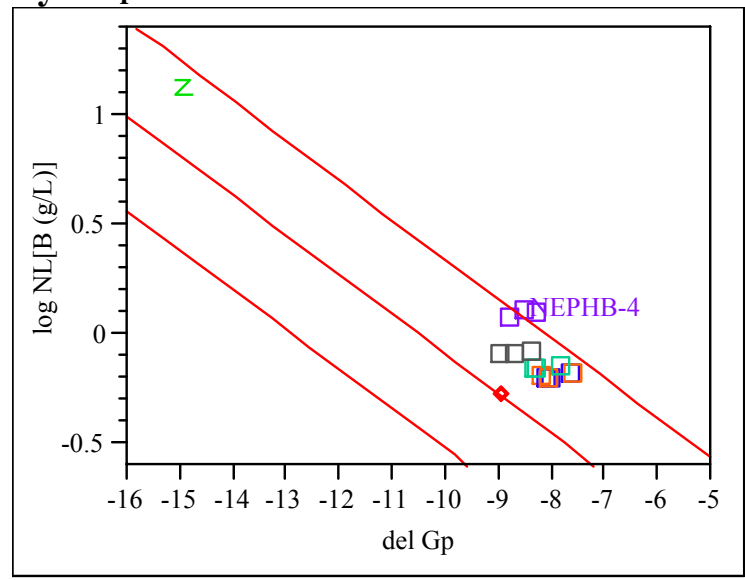

Linear Fit

\section{Bivariate Fit of $\log \mathrm{NL}[\mathrm{Li}(\mathrm{g} / \mathrm{L})]$}

By $\Delta \mathbf{G}_{\mathbf{P}}$

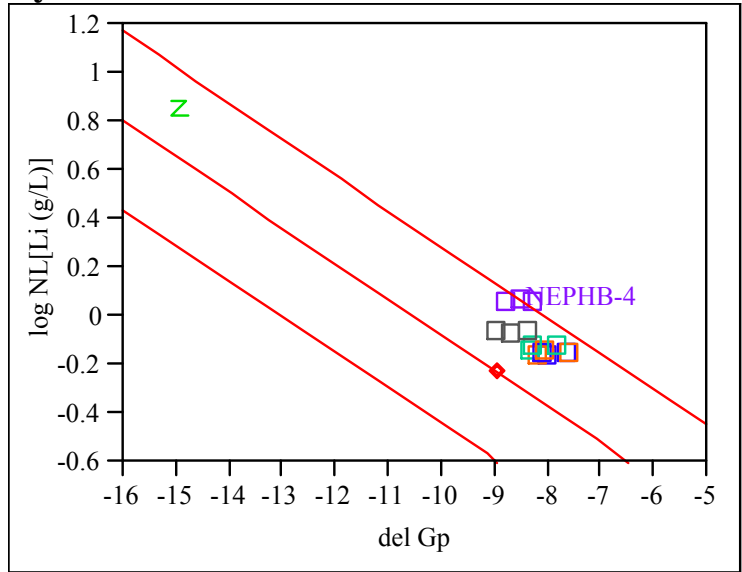

Linear Fit
Bivariate Fit of $\log$ NL[Na (g/L)]

By $\Delta \mathbf{G}_{\mathbf{P}}$

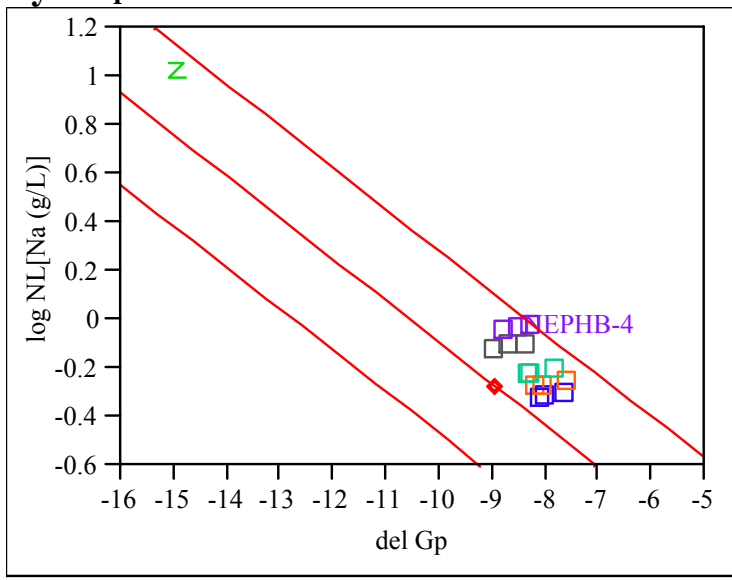

Linear Fit

\section{Bivariate Fit of log NL[Si (g/L)]}

By $\Delta \mathbf{G}_{\mathbf{P}}$

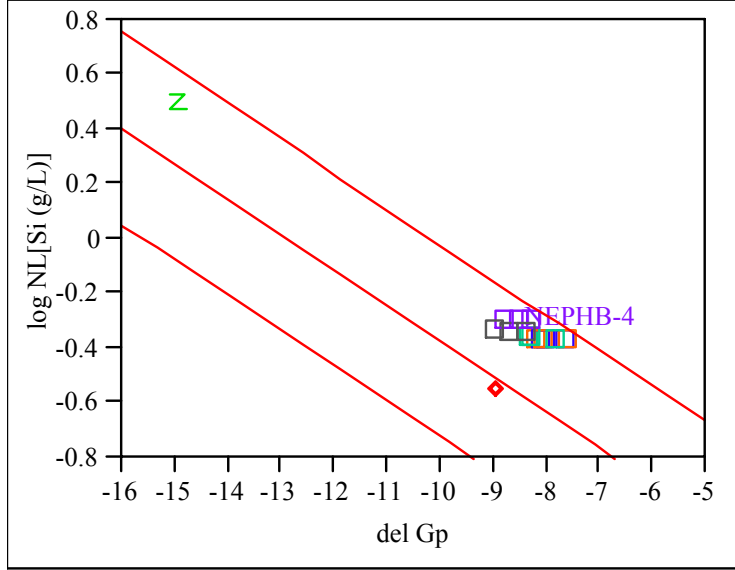

Linear Fit 